\title{
JUAN MARSÉ: BROADENING THE DEFINITION OF THE CATALAN NATION
}

\author{
BY
}

\section{DANA GUISASOLA}

\begin{abstract}
A thesis
submitted to the Victoria University of Wellington

in fulfillment of the requirements for the degree of
\end{abstract}

Doctor of Philosophy

Victoria University of Wellington 


\section{Table of contents}

Agradecimientos

Abstract

Introducción.

Juan Marsé: ficción, memoria, nación

Capítulo 1

Historias, estados, nacionalismos e identidades

Capítulo 2

Últimas tardes con Teresa: el registro del Otro y su incipiente potencia transformadora

Capítulo 3

La oscura historia de la prima Montse: hacia una apertura a un espacio de hibridez

Capítulo 4

El amante bilingüe: la destrucción de fronteras entre lo Propio y lo Otro

Capítulo 5

Nación abierta, lenguaje híbrido: la estrategia lingüística de Marsé

Capítulo 6

Algunas conclusiones

Trabajos citados 


\section{Agradecimientos}

Esta tesis ha podido llevarse a cabo gracias a una beca doctoral otorgada por Victoria University of Wellington Te Herenga Waka desde el año 2017. Agradezco especialmente a la Universidad no solamente por concederme la beca, sino también por financiar mi viaje de investigación a Barcelona, donde conocí y entrevisté a Juan Marsé, además de hacerme de valiosa bibliografía específica. Agradezco de corazón a Marsé su tiempo y su amabilidad. También quiero agradecer enormemente a mis supervisoras, las doctoras Sarah Leggott y Nicola Gilmour, quienes guiaron este proyecto con profesionalismo y entusiasmo. De ellas destaco su compromiso, su paciencia, su mirada crítica y su calidad humana. Deseo expresar además mi gratitud al Dr. José María Gil, quien muy generosamente revisó mi quinto capítulo y me sugirió bibliografía específica, dada su extensa trayectoria como lingüista. Agradezco asimismo a la Dra. Marcela Romano por facilitarme parte de la bibliografía de la que se nutre este trabajo, además de impulsarme a seguir estudiando cuando la posibilidad de un doctorado en Wellington era aún un sueño. Un agradecimiento especial también va dirigido a Nuria Bonet, bibliotecaria de la Biblioteca de Catalunya, a la bibliotecaria Eugenia Cañueto Vidal y al Dr. Albert Turull, ambos profesionales de la Universitat de Lleida, por su cálida orientación en mi viaje de investigación a Cataluña.

Doy también las gracias a mis "informantes" catalanes y peninsulares, quienes confirmaron muchas veces los "ecos de catalanidad" o simplemente los usos peninsulares de ciertos términos o estructuras gramaticales en los que yo sospechaba fenómenos de interferencia: a Ana Isabel Fernández León, a Nuria Romeu y a Claudia Grimau, mis amigas catalanas, a Daniel Molinero, mi primo de Madrid y a Tirtze Gabiria, mi prima vasca, muchas gracias. A mi hermana Nika, que vive en Barcelona hace algunos años y confirmó con sus amigos catalanes dudas específicas sobre este tema. 
A Pablo, por acompañar con amor mis éxtasis y mis frustraciones de tesista. A mis papás, Nanina y Néstor, por fomentar mi amor por la literatura y mis ganas de seguir aprendiendo siempre.

A todos ellos, muchas gracias. 


\begin{abstract}
This thesis argues that Catalan writer Juan Marsé (1933-2020) proposes, in a number of his novels, a postmodern construction of concepts of national identity in the case of Catalonia. The novels which are analysed in this study are Últimas tardes con Teresa (1966), La oscura historia de la prima Montse (1970) and El amante bilingüe (1991). Marsé's innovative and open concept of the nation is presented in these works through three different strategies, which I refer to as discursive, narrative and linguistic.
\end{abstract}

Marsé's discursive strategies are traced within the framework of textual semiosis, and comprise, for example, certain vocabulary choices over others, or the predominance of adjectives in certain parts of the text. These strategies thus relate to syntactical and grammatical aspects of the texts. Secondly, the author's narrative strategies are those related to the works' themes, linked to the analysis of the plot structure and the novels' settings and characters. The central issue addressed here is the inclusion of the figure of the charnego in the novels selected for study. The derogatory term charnego was coined in Catalonia to refer to people who migrated from the south of Spain to Catalonia during the 1960s. This wave of Spanish-speaking immigration increased the population of Catalonia by almost 1.5 million, and was overwhelmingly seen as negative by locals at the time. The representation of this figure in these novels is examined through an analysis of the physical descriptions and psychological portrayals of these characters, as well as the vocabulary used in these representations. My discussion of Marsé's narrative strategies also considers the different ways in which he portrays the idea of what it means to be "Catalan"; that is, the habits, traditions or symbols that traditionally provide a basis for identity. Finally, the linguistic strategy that runs through all Marsé's work can broadly be defined as the choice of Spanish—as opposed to Catalan—as his literary language. This thesis argues that this choice is not only a strategic one in terms of the 
broader dissemination of his message but is also a key element in his construction of a broader notion of Catalan nationhood.

These strategies interweave to present a shifting representation of Catalan national identity informed by postmodern perspectives and in opposition to traditional concepts of nationhood. Over the course of these three novels, Marsé progressively blurs the boundaries between what is traditionally viewed as "the Catalan" and "the Other". Through his portrayal of certain characters and spaces, and with significant linguistic interference from Catalan in his Spanish, Marsé undermines traditional boundaries between the identities of Self and Other and suggests a more fluid idea of nationhood.

This thesis makes three important contributions to existing scholarship. Firstly through its analysis of Marsé's postmodern construction of Catalan national identity in these three novels. Secondly, this study also comprises a detailed examination of La oscura historia de la prima Montse (1970), which has not been extensively studied by scholars to date. The comprehensive analysis of Marsé's use of language is a third original component of the study. It opens new possibilities for the linguistic analysis of other novels, both Marsé's and those of other Catalan writers. 


\section{Introducción}

\section{Juan Marsé: ficción, memoria, nación}

El escritor catalán de expresión castellana Juan Marsé (1933-2020) es uno de los novelistas de origen hispano más prestigiosos de los siglos XX y XXI. Ganador del Premio Nacional Cervantes, cuenta con más de treinta libros publicados entre novelas, ensayos y antologías de relatos. Siempre vigente, ha sido una figura clave en la historia catalana y peninsular reciente: desde la Guerra Civil y los primeros años de franquismo, hasta el Proceso Soberanista Catalán de los últimos años, pasando por la "Gauche Divine" y el célebre Boccaccio, la voz de Marsé se entrelaza con la historia peninsular del siglo XX y se torna inseparable de su espacio y de su tiempo. Su vasta contribución no solamente literaria sino también ensayística ha sido ampliamente estudiada. Esta tesis pretende continuar esa línea de investigación, y esbozar algunas nuevas líneas de interpretación de su obra. Se detendrá en el estudio de tres de sus novelas, y se enfocará en la representación de la progresiva disolución de fronteras entre lo autóctono y lo foráneo dentro de la representación de la nación catalana presentes en ellas.

Fiel a la tradición realista, la escritura de Marsé se sitúa en un espacio y en un tiempo familiares para el autor: el realismo pregona que no se puede dar fe de lo que no se conoce bien. El sustrato autobiográfico de sus obras ha sido asumido en múltiples ocasiones por el autor, quien afirma que en la construcción de muchos de sus personajes, escenarios y situaciones resuenan los ecos de su propia experiencia vital. En la "Introducción" a los Cuentos completos de Marsé, el filólogo catalán Enrique Turpin coincide con esta mirada sobre su obra, y observa que el novelista catalán amolda con éxito lo escrito con lo vivido, y lo imaginario con lo ocurrido (9). Por otra parte, Josep Maria Cuenca, quien a partir de seis años de minucioso trabajo documental publicó en 2014 la biografía de Marsé Mientras llega la felicidad, confiesa 
en una entrevista a El Periódico de Barcelona: “Quizá no tenga sentido que Marsé se plantee unas memorias porque ya están en sus novelas, pero una biografía, como mirada externa, sí lo tiene" (Hevia). La escritura de Marsé se alimenta de sus vivencias, y dibuja a lo largo de su obra un espacio acotado, que es la geografía de su propia peripecia vital. Marsé se nutre de la memoria y le hace decir a Paco Bodegas, narrador de La oscura historia de la prima Montse: "La memoria lo es todo para mí. Tanto recuerdas, tanto vales" (16). Prefigura de este modo una poética que se siente cómoda en la posición liminar, una poética que sintetiza los dos términos de las dicotomías y es, como la memoria, realidad y ficción a la vez, experiencia y relato, privada y pública. Es, entonces, relevante conocer algunas de sus circunstancias biográficas para una mejor lectura de la obra de Marsé.

Turpin observa que el paraíso de esa geografía personal de Marsé es la infancia y la adolescencia (14). El crítico refiere a la "Entrevista a Juan Marsé" de Juan Ramón Iborra, en la que Marsé añora esa Edad Dorada de la infancia: "Cuando pienso en una imagen de la felicidad auténtica, pienso siempre en aquel grupo de chavales, que debíamos tener (sic) de nueve a doce años, en el Penedès, en verano, entre los viñedos y los trigales [...]. ${ }^{1}$ Bueno, esa es para mí la imagen de la felicidad. Y ahí, en ese verano luminoso, el tiempo está parado. Después se pone en marcha y ya se acabó" (ctd en Turpin 16). Ese tiempo detenido de la infancia comienza para Marsé el 9 de enero de 1933, cuando nace en el barrio barcelonés de Sarriá, bajo el nombre de Juan Domingo Antonio Faneca Roca. Casi un mes después su madre muere por una complicación del parto, y su padre, único sostén económico de sus dos hijos pequeños (Juan era el segundo), no puede dejar su trabajo de taxista (Turpin 17). Sólo unos días después de la muerte de su esposa, una pareja sube al taxi en una clínica. Durante el viaje, le cuentan que acababan de perder a su primer hijo, y habían sido informados de que no podrían

\footnotetext{
${ }^{1}$ Dado que la escritura marseana es abundante en puntos suspensivos, resulta conveniente en esta tesis hacer una excepción al sistema de citado MLA 8 y encorchetar los puntos suspensivos que indican que la cita ha sido fragmentada para mayor claridad.
} 
tener más. El taxista, entonces, les describe su situación y la mujer le pide que la lleve a conocer al recién nacido. Juan Faneca Roca fue adoptado por el matrimonio esa misma tarde, en la que también cambió su nombre a Juan Marsé Carbó. "El taxista—cuenta Marsé-colocó también a mi hermana, a los pocos días, en casa de un pariente de mi madre muerta, y desapareció. Sólo le vi un par de veces en mi vida: el día de mi primera comunión y cuando se casó mi hermana" (ctd en Turpin 17). Sin embargo, en su retiro, en un pequeño pueblo de Cataluña, Mingo Faneca presumía de ser el padre de un escritor importante (Vázquez Montalbán "La memoria” 140). ${ }^{2}$ Vázquez Montalbán observa que el mito del padre aplazado se agranda en algunas novelas como Un día volveré, y otras veces subyace como sombra (140). Marsé no rehúye de esta temática y sostiene: "Comprendo que es un tema muy literario (o que a algunos les pueda parecer muy literario) pero nunca lo he abordado como tal, directamente, aunque mis libros están llenos de chavales que se inventan a sus padres, o que, como el Pijoaparte, ${ }^{3}$ deciden ser hijos de sí mismos" (ctd en Turpin 17).

Los padres adoptivos de Marsé provenían del campo de Tarragona. En 1931, una vez proclamada la Segunda República Española, se trasladaron a Barcelona, al barrio de La Salud, en el distrito de Gràcia, donde viviría Marsé hasta su matrimonio (Turpin 17). Su infancia transcurre entre el barrio de Gràcia y los veranos en la casa de sus abuelos, en el Penedès, Tarragona. Sus padres eran militantes de izquierda; Alberta Carbó Borrell ("Berta”) era telefonista en la sede central del PSUC (Partido Socialista Unificado de Cataluña) y Josep Marsé Palau (“Pep”) trabajaba como fumigador para la Generalitat. Había militado en el ERC

\footnotetext{
2 Josep María Cuenca descree de esta versión. El biógrafo de Marsé no encontró ningún registro del supuesto hijo muerto de los Marsé Carbó, y supone que la madre adoptiva urdió esta historia para evitarle a Juan la certeza del abandono. "La historia del taxi convierte a Mingo en un hombre generoso que con la entrega de su hijo mitiga el dolor de una madre herida por una grave pérdida, alejando así cualquier posibilidad de percibir a Mingo como un padre insensible que se desentiende de su hijo" (41). Cuenca encuentra, además, evidencia de que Mingo Faneca y el padre adoptivo estuvieron vinculados simultáneamente al partido nacionalista catalán Estat Català, por lo que es factible que se hayan conocido allí.

${ }^{3}$ El Pijoaparte es uno de los personajes principales de Últimas tardes con Teresa. Revisaremos su configuración en el segundo capítulo de esta tesis.
} 
(Esquerra Republicana de Cataluña), un partido republicano y separatista, y en 1936 ingresó al PSUC (Vázquez Montalbán "La memoria” 139).

También en 1936 comienza en España la Guerra Civil, a la que nos referiremos con mayor atención más adelante. Debido a que la contienda termina en 1939, cuando Juan tiene sólo seis años, su vida se vio afectada más por los efectos de esa guerra que por la guerra misma. La mayor consecuencia del enfrentamiento que tomó lugar entre 1936 y 1939 entre fuerzas republicanas y nacionalistas fue la instauración de la dictadura del general Francisco Franco, que se extendió desde 1939 hasta su muerte en 1975. Durante la dictadura, Josep Marsé es detenido varias veces debido a su militancia antifranquista, lo que lleva a Juan a interrumpir sus estudios formales en el Colegio del Divino Maestro en 1946, con sólo trece años. Esto es bien recibido por el novelista, quien recuerda: "Llamarle colegio es mucho [...]. Era una torre, una torre convertida en escuela por un personaje casi dickensiano (a la española, por supuesto: un Fagin ultrafranquista y ultracatólico), un hombre soltero que murió completamente loco [...]. Ahí estuve cautivo, de 1942 a 1946" (ctd en Turpin 20).

El abandono de sus estudios convierte a Marsé en un autodidacta. Es un lector obsesivo que devoraba cuanto texto caía en sus manos. "En esos días leía muchísimo, todo lo que pillaba. Balzac y El Coyote, Stendhal y Salgari, Stevenson y Edgar Wallace. Y las novelas de la Biblioteca de Oro y la literatura seria que publicaba José Janés y cuyos máximos exponentes eran Somerset Maughman y Lajos Zilahy... Y los descubrimientos: Santuario, de Faulkner, en la edición Austral" (ctd en Vila-Matas 150). En el documental Érase una vez Juan Marsé, agrega que sus influencias más rotundas son los tebeos, El Coyote, ${ }^{4}$ las novelas del Oeste y las de detectives, y las aventuras de Fu-Manchú, el villano creado por Sax Rohmer que protagonizó varias novelas de quiosco publicadas entre 1913 y 1935. Lee también a los maestros realistas

\footnotetext{
${ }^{4}$ Personaje de ficción creado por el novelista español José Mallorquí Figueroa en 1943, inspirado en El Zorro. Es uno de los personajes de novelas de quiosco más populares de España.
} 
del siglo XIX, sobre todo a Dickens y a Stendhal; y, ya un poco mayor, a Proust y a Joyce. Debido al hecho de que su padre se desempeñó durante muchos años como desratizador de salas de cine contratado por el gobierno local, el joven Marsé logra entrar gratis a todas las funciones. De este modo, también el cine estadounidense de los años 40 y 50 deja su marca en la escritura: "Dentro de esta formación cultural el cine fue algo así como el otro componente de los libros de aventuras, de la literatura. Yo iba muchísimo al cine desde chaval y sin duda han influido en mi obra los fantasmas de la cantidad de películas que he visto, pero también la manera de contar, cierta imaginería" (Amell 91). Estas influencias prefiguran una escritura de corte realista, en constante diálogo con el circuito masivo de la cultura popular.

Entre 1946 y 1959 Marsé trabaja como aprendiz de joyero. Los primeros dos añosentre sus trece y sus quince—son los que recuerda como los mejores, porque, como todavía era inexperto, el dueño de la joyería lo entrena muy lentamente, y Marsé se desempeña la mayor parte del tiempo como cadete y repartidor. De este modo, camina y explora no solamente cada rincón de su barrio, sino que también se familiariza con las calles del sur de Barcelona, donde se concentran los talleres en los que se graban iniciales en metal. Marsé se torna, entonces, habitué no sólo del barrio de Gràcia, sino también del Barrio Gótico y del Barrio Chino (Turpin 21). Los tres espacios geográficos delimitan uno de los loci más frecuentes de su novelística. Luego de dos años de desempeñarse como cadete, comienza a trabajar como operario en el taller de joyería. Paralelamente, comienza a escribir breves reseñas para la revista cinematográfica Arcinema.

Su trabajo en la joyería se ve interrumpido durante dieciocho meses, entre 1954 y 1955 en los que Marsé debe cumplir el servicio militar obligatorio en Ceuta. Su paso por el servicio militar favorece su formación literaria: "Tuve la suerte de conseguir lo que se llamaba 'un plantón'-explica Marsé—, un puesto de vigilancia, que resultó ser la finca de un teniente coronel. Una maravilla [...], me instalaba en el jardín a primera hora de la mañana y me pasaba 
el día leyendo. Y escribiendo" (ctd en Turpin 24). De su experiencia como conscripto en Ceuta proviene el relato "Teniente Bravo" (compilado en el libro de cuentos con el mismo nombre, de 1987) y la estructura de su primera novela, Encerrados con un solo juguete, producto del intercambio de cartas con su novia de entonces.

Ya de regreso en Barcelona, inicia formalmente su carrera literaria con la publicación de su relato "Plataforma posterior" en la revista Ínsula. Consigue publicar este relato por la mediación de una amiga de su madre, Paulina Crusat. Crusat también insiste en que el joven envíe un cuento, "Nada para morir", al premio Sésamo. Es así como Marsé gana el primer premio literario de su vida, en 1959. El entusiasmo por ese premio lo empuja a terminar de escribir Encerrados con un solo juguete, y a presentar el manuscrito en la editorial Seix Barral en 1959 para inscribirlo para el premio "Biblioteca Breve". No gana el premio, pero es contactado por Carlos Barral para publicar su novela, que se edita en 1960. Ese día comienza también la amistad entre Marsé y Barral, que se prolonga hasta la muerte de este último, en diciembre de 1989. Barral lo introduce en el circuito cultural barcelonés, donde conoce a Gabriel Ferrater, a Jaime Salinas y a quien sería su gran amigo, Jaime Gil de Biedma. Este grupo de intelectuales no solamente ordena y guía nuevas lecturas, contribuyendo así a extender su formación, sino que también media ante el organismo internacional Congreso para la Libertad y la Cultura en el otorgamiento de una "bolsa de viaje" para que Marsé pueda viajar a París una vez publicada su novela, ya en 1961 (Turpin 33).

Debido a que los fondos de la beca son escasos, Marsé consigue trabajo como asistente de laboratorio en el Departamento de Bioquímica Celular del Instituto Pasteur. Allí conoce al futuro premio Nobel de Medicina y Fisiología Jacques Monod, un comunista con quien suele dialogar sobre la situación del franquismo en España. Monod lo acerca al Partido Comunista, aunque Marsé afirma: "Me hice del Partido Comunista de España en París no por Monod, sino porque era el único que hacía algo contra Franco. Luego me separé por una cuestión de 
intransigencia" (ctd en Vázquez Montalbán "La memoria" 139). Su experiencia de compromiso y posterior desencanto del Partido Comunista moldea la mirada con la que Marsé caracterizará a sus personajes militantes en novelas como Últimas tardes con Teresa.

Su apremiante situación económica al regresar a Barcelona en 1962 lo lleva a publicar su segunda novela, Esta cara de la luna. Esta novela, escrita, como asegura Marsé "en el insuficiente, desvergonzado y a todas luces insensato tiempo de tres meses" (ctd en Turpin 36) con el único fin de cobrar sus réditos, es la única que Marsé aún no permite reeditar ${ }^{5}$ porque la ha escrito con prisa, algo que aprende entonces y para siempre, no debe hacerse nunca (Regàs 121). En Barcelona, profundiza su amistad con Jaime Gil de Biedma, quien revisa capítulo a capítulo, durante el proceso de escritura, el manuscrito de lo que sería su tercera novela, Últimas tardes con Teresa. El texto gana el premio Biblioteca Breve de Seix Barral en 1965 y es publicado al año siguiente. La novela es un éxito comercial, y es igualmente bien recibida por el ámbito intelectual y por el lector común. Últimas tardes con Teresa se configura así como la novela consagratoria de Marsé: "El éxito y las numerosas traducciones confirmaron el diagnóstico de Barral: Juan Marsé era el más original y certero de los novelistas del momento" (Regàs 121). Casi veinte años después, en 1984, es llevada al cine por Gonzalo Herralde, con guion del propio Marsé. Últimas tardes con Teresa es la primera de las novelas que estudiaremos en este trabajo.

También en 1966 Marsé abandona la casa de sus padres para casarse con la peluquera extremeña Joaquina Hoyas Gómez. En 1968, tienen a su primer hijo, Alejandro, y, en 1969, a Berta, que debutó como narradora en 2006 con su libro de cuentos Jaque. En 1970 Marsé es también nombrado redactor jefe de la revista Bocaccio, publicación clave en el tardofranquismo barcelonés, asociada al grupo intelectual catalán que Joan de Sagarra denominó la Gauche Divine. Este heterogéneo grupo de jóvenes intelectuales y profesionales

\footnotetext{
${ }^{5}$ Ha sido desterrada, también, de sus Obras completas.
} 
progresistas estaba formado por, entre otros, Oriol Regàs, Terenci Moix, Ana Maria Moix, Jaime Gil de Biedma, Salvador Clotas, Francisco Umbral, Carlos Barral y Manuel Vázquez Montalbán. Provenían de la burguesía catalana castellanoparlante y rechazaban en la misma medida la cultura oficial del franquismo y la militancia comunista. Su producción cultural fue clave para la modernización de Cataluña (Villamandos 459). La revista nace en la mítica discoteca "Bocaccio", centro de reunión de la Gauche Divine, y versa sobre temas de cine, moda, teatro, y “nuevas ideas”. Es prohibida por la censura franquista en 1974.

En 1970 Marsé publica su cuarta novela, La oscura historia de la prima Montse, que confirma su lugar consagrado dentro del circuito literario español. "Escrita a golpes de coraje y belleza literaria, ataca con los puños, como un boxeador ciego de ira, el tema de la confusión emocional que la caridad supone para la prima Montse, y deja al descubierto la falsedad y la criminalidad que encubren ciertas actitudes liberales" (Regàs 122). Esta novela, la segunda que analizaremos en este trabajo, es recibida con admiración por el ámbito intelectual y por el lector común, y reafirma la mirada crítica, irónica y corrosiva de las instituciones, ya ensayada en Últimas tardes con Teresa, que se sostiene a lo largo de toda su producción narrativa a partir de entonces. Fue llevada a la pantalla grande por Jordi Cardena en 1978.

Aunque hasta La oscura historia de la prima Montse Marsé ha eludido a la censura franquista, sabe que su quinta novela, Si te dicen que caí $(1973)^{6}$ no iba a poder publicarse en la España de Franco. Esta certeza acarrea dos consecuencias. La primera, de orden práctico, es que Marsé presenta el manuscrito en el exterior, para el Premio Internacional de Novela en México. La segunda, más abstracta, es que por primera vez Marsé escribe "sin pensar en la reacción de la censura ni en los editores ni en los lectores, mucho menos en conseguir anticipos, premios, o halagos. [...]. [Escribe] implicadísimo y desembarazado por fin del pálido fantasma

\footnotetext{
${ }^{6}$ La novela toma su nombre de un verso de "Cara al sol”, el himno de la Falange Española.
} 
de la autocensura"7 (Turpin 54). Si te dicen que caí gana el premio y es publicada por la Editorial Novaro en la ciudad de México en 1973. Es una novela diferente, considerada por la crítica por su complejidad estructural, y por la maestría con la que el autor funde apariencia y realidad (Turpin 62). Si te dicen que caí es, para Marsé, "la secreta y nostálgica despedida de la infancia, el deseo de recorrer el barrio que le vio crecer" (ctd en Turpin 62). La novela es llevada al cine por Vicente Aranda en 1989.

Entre 1974 y 1978, durante la transición hacia la democracia, Marsé escribe semanalmente en la revista de humor satírico Por Favor y en el semanario Muchas Gracias. Algunos de estos textos periodísticos, que posan una mirada crítica sobre distintos sucesos de la actualidad catalana y española de su tiempo, son compilados en los libros Señoras y señores, de $1975,{ }^{8}$ y Confidencias de un chorizo, editado en 1977. Un año más tarde, Marsé publica su sexta novela, La muchacha de las bragas de oro con la que obtiene el Premio Planeta ese mismo año. Si bien esta no ha sido la novela mejor reputada de Marsé, da cuenta de su momento histórico; se centra en la figura de un falangista que, al redactar sus memorias, falsea su biografía para justificar su compromiso político con el franquismo. Esta es, también, una de las pocas novelas de Marsé que no se sitúa geográficamente en Barcelona, sino en Calafell. La muchacha de las bragas de oro también es llevada al cine por Aranda en 1980.

En 1982, publica Un día volveré, una novela que muestra las marcas que el franquismo ha dejado en la población catalana y española. Turpin afirma que esta novela es "la crónica

\footnotetext{
${ }^{7}$ Durante la época de Franco, cualquier manifestación artística o periodística era revisada por la Delegación Nacional de Propaganda "que intervendría en los planes editoriales que todos los editores deben enviar, cuidando, fundamentalmente, de tres aspectos: ortodoxia, moral y rigor político" (ctd en Jiménez 4). Pedro Jiménez observa: "El ejercicio prolongado de la censura provoca la autocensura, la castración intelectual y destruye potenciales vocaciones, al mismo tiempo que priva a los ciudadanos de los elementos necesarios para su formación cultural" (3). La censura, entonces, puede plantearse como un dispositivo disciplinario de vigilancia en el sentido del panóptico foucaultiano, en tanto es impuesto desde fuera-en este caso, desde el Estado-pero finalmente es interiorizado por el sujeto. De este modo, la imposición de la censura deshumanizadora por el franquismo tiene un efecto de asimilación en los artistas disidentes, que llevan a cabo sus prácticas artísticas-en este caso, literarias - internamente disciplinados dentro de la lógica de la vigilancia estatal. En otras palabras, se "autocensuran".

${ }^{8}$ Que también incluye artículos publicados en el periódico El País.
} 
negra de unos seres que se enfrentaron a una circunstancia dramática y desesperada (el deseo de invertir el resultado de una guerra perdida), y en la crónica resultante conviven las fechorías y los ideales" (71). Profundamente influenciada por la imaginería cinematográfica, Un día volveré también registra que, en los primeros años de la democracia, "la desmemoria es la terapia nacional” (Turpin 72). ${ }^{9}$ En 1984, Marsé publica su única novela corta, Ronda del Guinardó, con la que obtiene el Premio Ciudad de Barcelona en 1985. Esta novela, que da origen a la película dirigida por Wilma Labate, Domenica (2001), se desarrolla en una sola jornada (el 8 de septiembre de 1945), en un solo lugar (los montes del barrio de Guinardó) y en torno a una sola acción (un policía que acompaña a una niña huérfana para que reconozca el cuerpo de su supuesto violador) (Mainer “Juan Marsé” 10). En 1984 Marsé sufre también un infarto que lo lleva a una intervención quirúrgica para colocarle un doble bypass. Durante su larga recuperación, escribe el relato para niños La fuga del río Lobo y esboza los cuentos que dan cuerpo a Teniente Bravo (1987). ${ }^{10}$

En 1990 edita El amante bilingüe, y gana por segunda vez el Premio Planeta. Esta novela, que también es llevada al cine por Aranda en 1993, se sitúa en la Cataluña de la normalización lingüística y narra la historia de psicosis y decadencia de un hombre luego del abandono de su mujer. La novela hunde sus raíces en la tradición esperpéntica y describe la esquizofrenia de un hombre, pero también de la de una región en tensión entre dos lenguas. Nos detendremos en el estudio de esta novela en el capítulo cuarto de esta tesis.

En 1993, Plaza y Janés edita El embrujo de Shangai, que también será adaptada al lenguaje cinematográfico por Fernando Trueba en 2002. Ernest Folch afirma que esta novela “no es solamente una exhibición de poderío narrativo [...] sino que es también al mismo tiempo

\footnotetext{
${ }^{9}$ Nos referiremos al tema de la memoria más detalladamente más adelante en esta "Introducción".

${ }^{10}$ Uno de los cuentos que da cuerpo a Teniente Bravo, "El fantasma del cine Roxy", dio lugar a la letra de la canción del mismo nombre, firmada por Marsé y Joan Manuel Serrat, compilada en el álbum de éste último, Bienaventurados (1987). Se observan nuevamente las estrechas vinculaciones que existen en la obra de Marsé con la cultura popular (literatura, cine, canción).
} 
un testimonio de la heroica resistencia durante la guerra civil y los duros tiempos de la posguerra [...] Y expresa también, de principio a fin, una extraña nostalgia, casi enfermiza, de la infancia” (426). La infancia, como hemos visto, es un tema central en Marsé, y también será central en su novela Rabos de lagartija (2000), publicada tres años después de recibir el premio Juan Rulfo de Literatura Latinoamericana y del Caribe. ${ }^{11}$ Víctor, el narrador intrauterino, relata las conversaciones que tiene con su hermano David a través del vientre de su madre. Nuevamente, Marsé retrata en esta novela las marcas que la posguerra deja en la población adulta, y la inocencia con la que un niño interpreta esos hechos. Escrita durante la recuperación de la segunda operación de doble bypass de Marsé en 1999, la novela—con la que ganó el Premio de la Crítica y el Premio Nacional de Narrativa en España—condensa un proyecto más extenso que la convalecencia no permitió abordar: "Lo que iba a ser un volumen de casi mil páginas, con diferentes calas cronológicas, se convierte al fin en la novela con la que el escritor se despedía del siglo y del milenio, saludando los tiempos venideros con un guiño desmitificador y un deslumbrante poderío verbal" (Turpin 84).

En 2001, publica Un paseo por las estrellas, una recopilación de treinta y seis artículos sobre cine publicados originalmente en el periódico El País. En 2002 publica una nueva recopilación, esta vez de sus Cuentos completos, que incluye los de Teniente Bravo y otros cuentos dispersos. Su próximo libro también versa sobre cine, Momentos inolvidables del cine (2004). También en 2004 publica La gran desilusión, un "libro personal, escrito originalmente en los setenta, que recorre las décadas de los treinta y cuarenta a través de una especie de miscelánea de imágenes y recuerdos que remitían tanto a noticias y fechas históricas como a vivencias, modas y costumbres vinculadas al acontecer cotidiano, a la memoria popular de una época" (Lamadrid).

\footnotetext{
${ }^{11}$ También en ese año, 1997, publica Las mujeres de Juanito Marés, una antología de ensayos.
} 
En 2005 llega finalmente su duodécima novela, Canciones de amor en Lolita 's club. El hecho de que la novela haya sido, originalmente, planteada como guion cinematográfico ${ }^{12} \mathrm{da}$ como resultado una novela de diálogos abundantes e intensos que ponen de manifiesto la maestría de Marsé para retratar a sus personajes a partir de sus propias palabras. Finalmente, Canciones de amor en Lolita 's club termina siendo llevada al cine por Aranda, en el 2007. Esta novela es el último argumento que el jurado necesita para otorgar a Marsé, finalmente, el Premio Cervantes en 2008, cuarenta y ocho años después de la publicación de su primera novela.

Infatigable, Marsé publica en 2011 Caligrafía de los sueños, una novela definida por el autor como una defensa de la memoria personal que, como cualquier otra, "es una rama más de la memoria colectiva" (Escobedo 126). En esta novela las coincidencias biográficas son numerosas; el personaje principal nace el mismo día que Marsé, es adoptado, trabaja en una joyería y quiere ser escritor. En Noticias felices en aviones de papel (2014) también resuenan ecos autobiográficos, en tanto describe la historia de un adolescente abandonado por su padre que deberá acomodarse al mundo sin demasiada suerte (De Azúa). Finalmente, en 2016 Marsé publica su última novela, Esa puta tan distinguida, que narra la historia de un guionista que, en 1982, es contratado para escribir el guion de la película sobre el asesinato de una prostituta que fue estrangulada con un trozo de celuloide de la película Gilda en 1949. El guionista sostiene una serie de entrevistas con el asesino, que ya ha cumplido su condena en la cárcel. En 2017, Marsé publica Colección particular, una antología que incluye nueve cuentos ya publicados, ensayos, textos periodísticos y un cuento inédito. ${ }^{13}$

\footnotetext{
12 “A principios de enero de 2002 y por encargo de Trueba, Marsé comenzó un proyecto de guion cinematográfico que tituló El guardián del abismo. Aquel intento acabó en esta historia sobre el club Lolita” (Conte 467).

${ }^{13}$ Hemos omitido tres publicaciones en este resumen sobre la obra de Marsé: El pijoaparte y otras historias (1981) y Los misterios de colores (1993) son libros constituidos a partir de fragmentos de Últimas tardes con Teresa y La oscura historia de la prima Montse, respectivamente. Tampoco nos hemos referido a El detective Lucas Borsalino (2013), un cuento infantil breve ilustrado por Roger Olmos y editado por Alfaguara dentro de la colección "Mi primer...", que edita cuentos dirigidos al público infanto-juvenil de escritores consagrados.
} 
El conjunto de las obras de Marsé puede plantearse como una gran red textual de múltiples relaciones intratextuales e intertextuales. Sin embargo, Turpin observa:

A pesar de las vinculaciones que existen entre la obra breve de Juan Marsé y su actividad novelística, únicamente es posible apresar alguna de las verdades que estos cuentos encierran desde la lectura individualizada de cada uno de ellos[...]. El conjunto pone de manifiesto el complejo entramado de temas, motivos y recursos que hacen que sus narraciones tomen la forma de una lagartija que se muerde la cola, esto es, se convierten en algo circular y perpetuo (127).

Los lineamientos que atraviesan esta compleja red intertextual consolidan una poética propia, que en sentido global cuenta con determinadas características. La primera de estas características se vincula con su colocación en el campo literario e intelectual de su tiempo, pues Marsé se presenta como una figura atípica dentro del circuito cultural catalán y español. En su autorretrato publicado en el diario El País y compilado en su libro de 1975 Señoras y señores, dice de sí mismo que "no se considera un intelectual, y soporta mal que lo traten como si lo fuera". Agrega, en una entrevista: "No soy, por otra parte, ni pretendo ser, un teórico sobre el arte de la novela, no sé explicar bien muchas cosas que hago, y tampoco pierdo mucho tiempo pensando, me dedico a escribir y punto" (Guisasola 287). Se alinea junto a William Faulkner y con Juan Rulfo, y afirma: "Me gustaría verme reflejado como una especie de Faulkner, por ejemplo, que tampoco le gustaba hablar de la faena y se ponía a hablar de cosas del campo y de los campesinos, pero yo no lo sé hacer. O bien como Rulfo, que contestaba con monosílabos, 'sí', 'no', 'sí señor', 'no señor’” (Ballesteros, 00:07:04 - 00:07:29). Marsé afirma que más que un intelectual es un novelista, y que no le gustan las clasificaciones, pues no cree pertenecer a ningún grupo cultural: "Siempre me ha molestado un poco que me quieran encasillar. Soy bastante quisquilloso con lo de mantener una independencia en todos los sentidos: en el sentido político, en el social, incluso en el profesional” (Pérez 130). Se posiciona en el lugar del francotirador: 
Me considero una especie de francotirador. No milito en ningún partido, y, por lo tanto, no tengo ningún sentimiento gremial o corporativo o como lo quieras llamar. No me siento vinculado a nada y también tengo que decir independientemente de las ideas, tanto franquistas como las que sean, que no tengo ninguna predilección por la figura del político, la figura del representante del poder. Ejercer la crítica en un régimen dictatorial como era el franquista lo consideraba una obligación. En la actualidad, lo ejerzo por vocación. Porque si uno vive aquí se da cuenta de ciertas cosas y me parece lo más normal y lógico meterse con esos personajes que dejan bastante que desear. (Amell 89)

Esta cita hace manifiesto que más allá de cómo se configuren las cuestiones de lo Otro y lo Propio - dentro de Cataluña, o dentro de España-Marsé permanece siempre en una posición de borde con respecto a estas dicotomías.

El hecho de que Marsé cuente con una trayectoria de casi sesenta años como escritor contribuye a las dificultades para encuadrar desde una perspectiva historiográfica una producción literaria que abarca varias etapas de la evolución literaria española. Por otra parte, el propio posicionamiento como francotirador del autor, sumado a una formación asistemática, de influencias heterogéneas - $y$ heterosemióticas, también, si se tiene en consideración la influencia decisiva que tiene el cine en la escritura de Marsé, pero también la música popular, como el bolero-consolidan una poética original, que rehúye de las etiquetas críticas.

También la extensión de su carrera literaria evidencia la relatividad de su colocación dentro del contexto cultural y político de su época. Los diversos momentos históricos que atraviesa como figura literaria-y como ser humano-fueron modificando sus valores de referencia. En un contexto político tan variable como el de España y Cataluña desde 1933 hasta hoy, el lugar que Marsé ocupa en relación a lo dominante y a lo subalterno se modifica: progresista de la Gauche Divine durante el franquismo, supo dar cuenta de la diferencia cultural de Cataluña a través de su literatura, evitando al mismo tiempo la militancia nacionalista y la censura. Luego de la muerte de Franco, desplegó su risa mordaz sobre los intentos catalanistas de reestablecer la autonomía perdida, al tiempo que hizo evidente la imposibilidad de volver el 
tiempo atrás. Como advierte Joan Resina: "Marsé considera la identidad catalana posfranquista un ardid político en el que la realidad está siempre perdida en el simulacro" (Barcelona 153). Sin embargo, Resina también es crítico con el silencio de Marsé sobre la modulación política detrás del binomio Propio/Otro (Barcelona 152).

Existe otro factor que obstaculiza aún más la clasificación de Marsé como escritor y como novelista. Este factor, de tipo lingüístico, se vincula con el hecho de que Marsé es un escritor catalán que escribe en castellano. En este sentido, el narrador fundamenta su opción por el castellano a partir de los cuarenta años de represión franquista sobre su lengua. Marsé no solamente aprendió la lengua en el ámbito doméstico y de forma clandestina, sino que todas las lecturas que consolidaron su formación autodidacta fueron en castellano, debido a que no existía-por lo menos, en un primer momento-circulación de textos en catalán. ${ }^{14}$ Esto fortalece su imagen de francotirador:

No pertenezco a la cultura catalana, dicen, porque escribo en castellano. Evidentemente, pues sí. Aunque vivo en Cataluña, vivo la cultura catalana, pero no se me admite muy bien. Pero tampoco del otro lado, porque soy un escritor catalán que escribe en castellano. Escribo en castellano, pero soy catalán [...]. Bueno, pues bien, esa posición que estoy a medias es la más cómoda para mí: puedo disparar a un lado y a otro. Puedo criticar a unos y a otros, puedo ponerlo todo en solfa, que es una de las funciones del escritor. (Pérez 130)

El único rótulo que tolera la escritura de Marsé es el de "realista", aunque con sus especificidades. Desde sus inicios, cuando ya el agotamiento del realismo social era evidente,

\footnotetext{
${ }^{14}$ En la entrega del Premio Planeta por El amante bilingüe, frente a la pregunta de un periodista por su opción por el castellano, Marsé añade que escribe en esta lengua "porque le gusta" y porque "vive en una sociedad bilingüe". Resina advierte que Marsé olvida las tensiones de tipo dominancia-subalternidad que subyacen a su elección, y subraya el hecho de que el mercado literario en castellano ofrece mayores regalías que el catalán (Barcelona 170). Jordi Cornellà-Detrell, por otra parte, observa que debido a la represión del catalán en la esfera pública durante el franquismo, éste fue resguardado principalmente dentro del contexto escrito, en el que gramáticos y editores reglamentaron un registro normativo-purista. Esto "produjo inseguridad y frustración en la comunidad de habla, pues la enseñanza de lengua no estaba incluida en el currículo escolar, por lo que ellos no resultaron capaces de manejar estas normas. Esto llevó a muchos hablantes a considerar que su conocimiento de la lengua era deficiente" (40). Martí i Castell se refiere a esto como "un sentimiento de frustración cultural” (ctd en Cornellà 40).
} 
Marsé rehuyó de la retórica culturalista—propia del vaivén característico de la evolución literaria española, que oscila alternativamente entre la prioridad de la historia y la prioridad de la forma - y buscó soluciones en el interior del realismo, impulsado por el deseo de contar una buena historia. No procuró inventar palabras, alterar la sintaxis, apelar al retorcimiento del lenguaje, sino que apostó a tratar de convencer a su lector de la posibilidad de que aquello que se narra puede haber ocurrido en la realidad (García Montero 61).

Como para todo realista, la verosimilitud es uno de los vértices de su praxis escrituraria. La labor del novelista es, para Marsé, partir de una base estrictamente entroncada en la realidad y desarrollarla, mediante la imaginación, para llegar a otras posibilidades de realidad, otros hechos que no han sido, pero que podrían haber sucedido perfectamente (Pérez 124). La posibilidad de construir mundos creíbles se torna una vía de escape frente a una realidad que lo rechaza: afirma su creencia de que existe en su caso un desajuste con la realidad que lo envuelve (su país, su ciudad, su época, su propia experiencia personal) que no lo convence, y que es precisamente esto lo que lo lleva a buscar otras posibilidades de realidad en la literatura. Para Marsé, la escritura responde a una realidad difícil, es una "réplica a la vida, a la realidad" (Martí 11). En otras palabras, Marsé escribe “por la sensación de que el mundo no está bien organizado" (Vidal y Secorun 68).

El sustrato del que se nutre y sobre el que se asienta ese realismo es la memoria, y en esto hay un acuerdo generalizado entre la diversidad de críticos que se han detenido en su trabajo, y hasta en las afirmaciones de Marsé. Al recibir el Premio Cervantes en 2008 expresó:

Imaginación y memoria, para el escritor, son dos palabras que van siempre entrelazadas y a menudo resulta difícil separarlas. Ciertamente un escritor no es nada sin imaginación, pero tampoco sin memoria, sea esta personal o colectiva, esté proyectada en la novela histórica de fecha más remota o en la literatura de ficción científica más futurista y fantástica. No hay literatura sin memoria. Incluso la memoria trapacera puede hacer buena literatura. La tan reiterada advocación "hay que olvidar el pasado" lógicamente no se aviene con la naturaleza de la función de la escritura. Hay que acotar nuevas parcelas de la 
memoria, hacer más denso el laberinto, cuidando pues, de dejar una traza de hilo, como hizo Teseo aquella vez, para poder volver al exterior y contarlo. ${ }^{15}$

Marsé exige recordar un pasado que gran parte de la sociedad española se propone olvidar, después de cuarenta años de dictadura franquista. Pertenece, como señala David Castillo, a la generación que surge del silencio impuesto por la represión franquista (45), pero se distancia del mutismo impuesto por la censura y enarbola la bandera de la memoria en una colectividad dispuesta a olvidar (Suñén 131). Marsé bucea en su memoria personal—ya hemos visto los ecos biográficos que tiene su escritura-, y pone esa vivencia en relato, articulando su propia memoria personal con la memoria colectiva de la posguerra.

Así como la opción por el realismo es, para Marsé, una posibilidad de inaugurar mundos mejores, sus raíces en la memoria se asocian con aportar una contra-versión de la experiencia de la posguerra. El novelista observa: "Más o menos todo el mundo coincide con que en la posguerra se pasó hambre y eso es indiscutible. Luego puede venir, y de hecho vino, la versión oficial, la versión oficial era que no, que aquí todos vivíamos en el paraíso, vamos, el franquismo se ocupaba de todo eso" (Doria y Gilaberte, 00:07:24 - 00:07:48). La contra-versión de Marsé hunde sus raíces en su propia memoria personal, fragmento de la memoria del pueblo, y subvierte la versión oficial estatal. Agrega: “La versión oficial suele mentir acerca de la memoria colectiva, pero la memoria colectiva está ahí, nadie te la puede quitar. Siento un hartazgo de las versiones oficiales, intentando imponer un pasado glorioso" (Doria y Gilaberte, 00:07:55 - 00:08:23).

Consideramos, con Antonio Gramsci, que los sectores dominantes producen una determinada visión de mundo para asegurar la reproducción de la dinámica social. Esa visión de mundo (la hegemonía), es heredada sin cuestionamientos por el grupo dominado que "la

\footnotetext{
${ }^{15}$ Discurso completo disponible en: http://www.soitu.es/soitu/2009/04/23/info/1240485285_776462.html?id=51c77a6e40534f0a305cc8a98bb60ca4 $\& \mathrm{tm}=1240522476$
} 
afirma verbalmente y hasta cree seguirla, porque efectivamente la sigue en 'tiempos normales', o sea, cuando la conducta no es independiente y autónoma, sino sometida y subordinada" (Gramsci 367). Es desde esta perspectiva que consideramos que Marsé construye en su novelística una contra-narrativa, crítica y cuestionadora de la versión hegemónica. La escritura de Marsé, profundamente afincada en la memoria, pone de manifiesto la falsedad y el carácter de constructo de la versión oficial y repone el registro de la memoria popular. ${ }^{16}$ Marsé sostiene que en España la versión oficial de los hechos era única y totalitaria, producida por los sectores dominantes, es decir, por la dictadura y por el púlpito. Frente a la imposición de esta versión de la realidad, el acto de recuperar la memoria colectiva y popular da lugar a la posibilidad de explorar a una versión-otra. Agrega que durante el franquismo la imposición de una verdad oficial configuró un relato de la coyuntura social falso, pues la realidad del pueblo era diferente a lo que la versión dominante pretendía instalar. "De ahí proviene esa especie de recreación de la voz popular para reivindicar unos hechos tal y como eran. Naturalmente, como es una novela, es una mentira sobre una mentira. Los niños falsean o inventan, pero esa invención, curiosamente - y esto es lo que en definitiva me interesa del arte de la novela—se acerca más a la verdad que la versión oficial” (Recio 121).

José-Carlos Mainer observa que, en Marsé, los juegos de la memoria oscilan, siempre, entre la verdad y la mentira (“Juan Marsé o la memoria en carne viva” 71). La versión oficial miente, la ficción se aproxima más a la verdad: en Marsé, la apariencia y la realidad se consolidan como las dos direcciones posibles de una escritura pendular. Marsé afirma que la novela - contrahegemónica de la versión oficial y, por lo tanto, "menos falsa"— no pretende reflejar exactamente la realidad, sino una realidad posible: "La cuestión es que lo hagas de manera tan convincente, que parezca verdad" (Recio 130). El relato de la experiencia—aquello

\footnotetext{
${ }^{16}$ Dada la limitada extensión de esta investigación, no entraremos en debates teóricos sobre este concepto. Cabe aclarar, sin embargo, que Marsé entiende la memoria popular como el conjunto de experiencias vividas por el sector de la población desfavorecido por la coyuntura de la Guerra Civil y la posguerra.
} 
que Walter Benjamin definía como "Erfahrung", la experiencia articulada a través de procedimientos asociados al relato, que se distingue de "Erlebnis", la vivencia física y corporal, pre-lingüística — se integra en el lenguaje, y, por lo tanto, debe estructurarse en el discurso, distorsionándose. ${ }^{17}$ Marsé no es inocente a estos mecanismos, y su escritura se multiplica en una continuidad de espejos fragmentados, en los que se confunden las ideas de versión, de memoria, de ficción. Como añade Santos Sanz Villanueva, los equívocos y las apariencias dan cuenta de una mentira totalizadora que se constituye como relato colectivo: "Las apariencias, el engañoso espesor de la realidad, se irá poco a poco convirtiendo en la columna vertebral de la obra de Marsé bajo un imperioso y renovador estímulo, la memoria” (8).

La memoria personal de Marsé, hijo de militantes de izquierdas, republicanos y catalanistas, es la memoria de los vencidos. Sólo tenía seis años cuando el franquismo resultó vencedor de la Guerra Civil, pero, aunque afirma que él personalmente no ha perdido ninguna guerra, ${ }^{18}$ sí se ha considerado siempre un hijo de perdedores (Recio 131). Asume esa herencia, confiesa que los personajes marginales y derrotados le resultan más interesantes (Amell 88), que se entiende mejor con ellos (Doria 325) y se posiciona él mismo dentro de ese grupo. Además, hace público su desprecio por la escritura a favor de los ganadores y sostiene: "Yo recuerdo que en las novelas que he leído de los vencedores de la Guerra Civil [...] se nota algo. La prosa de esas personas segrega una especie de baba, la baba del vencedor" (Recio 123). Su escritura, entonces, delineará con simpatía una serie de personajes golpeados por la vida, marginales, fracasados. Como apunta Castillo, esta forma de mirar lo lleva a explicar el mundo subjetivamente, desde la visión de los perdedores, de la gente sencilla (46).

\footnotetext{
${ }^{17}$ La diferencia entre Erfahrung y Erlebnis es desarrollada por Benjamin en "Sobre algunos temas en Baudelaire" (195).

${ }^{18}$ Es esto lo que lo encuadra dentro de lo que la historiografía española denomina "los niños de la guerra". Este colectivo está formado por el conjunto de quienes eran todavía niños durante la contienda civil, y se refiere tanto a los niños que permanecieron en España como a los que se exiliaron con sus padres (Alted Vigil 47).
} 
La memoria de lo vivido también delimita una zona geográfica: salvo escasas excepciones, la novelística de Marsé se circunscribe un ámbito específico, dentro de la ciudad de Barcelona. Ernesto Ayala-Dip observa que el espacio geográfico en el que Marsé contextualiza sus novelas no es un lugar mítico-como el Santa María de Juan Carlos Onetti, el Yoknapatawpha de William Faulkner o el Macondo de Gabriel García Márquez-sino que es localizable en el ámbito de la realidad, lo que, afirma, lo torna un espacio histórico. Agrega que el lugar de la ficción es, en Marsé, una responsabilidad de la memoria. Su Barcelona se construye a partir de una memoria que no solamente es evocadora y registra las calles, las tiendas, las casas de la memoria personal, sino que también es una memoria fundadora que inaugura una topografía literaria (34). En su fundación, Marsé recupera, también, la Barcelona vencida, desde los ojos de los perdedores. No es exacto afirmar que las calles que retrata el narrador catalán en sus ficciones existieron tal y como se las describe, pero sí es innegable que sus características dan cuenta de una época que definitivamente moldeó a quienes la habían vivido. De este modo, su escritura se sitúa en un punto específico en el que confluyen espacio, tiempo y experiencia personal: "Estoy hablando de una Barcelona mental, una Barcelona de la memoria. Tiene que ver con mi infancia, con mi juventud", afirma (Ballesteros, 00:10:46 00:10:54). Esa topografía no se circunscribe a un barrio específico, sino que es un "cóctel de barrios que inauguran un barrio ideal que no existe, que existe solamente en mi cabeza" (Vázquez Montalbán “El intelectual”, 00:05:15 - 00:05:24). En ese espacio confluyen lo particular-ciertas calles, ciertos cafés, ciertos rincones localizables en el espacio-y lo general — esos espacios conocidos por el autor operan como escenarios para el desarrollo de temas universales como el amor, la traición, el abandono.

La Barcelona literaria de Marsé cumple con los requerimientos del verosímil realista, pues es “de ficción, pero con raíces en la realidad, claro, porque si no, no se aguantaría” (Doria y Gilaberte, 00:05:30 - 00:05:38). En este sentido, el novelista afirma que sitúa sus historias en 
un espacio que conoce a la perfección en búsqueda de verosimilitud (Pérez 124). ${ }^{19}$ Hay, como observa el autor, un trasvase de calles y edificios. El ámbito que inspira la ciudad literaria de Marsé abarca los barrios de Gracia, el Guinardó, la Salud, el Barrio Chino (actualmente, el Raval), el Paseo Marítimo y la Playa de la Barceloneta, y el Monte Carmelo. Para ingresar en la topografía literaria de Marsé, no sólo se requiere de una localización en el espacio, sino también en el tiempo, ya que, como observa el escritor, "la ciudad ha cambiado en todos los sentidos. Físicamente, por ejemplo, está más abierta al mar, y ciertos barrios han cambiado mucho" (Guisasola 281).

La construcción de la poética de Marsé se lleva a cabo a través de una escritura meticulosa y elaborada. En el estudio donde trabaja, el novelista ha escrito a mano una cita de Ezra Pound, que colocó al costado de su ordenador y dice: "El esmero en el trabajo es la única convicción moral del escritor". Al recibir el Premio Cervantes, Marsé propone una analogía entre su trabajo artesanal como joyero, cuando era muy joven, y sus hábitos de trabajo. Confiesa tener dos principios a la hora de escribir: procurar tener una buena historia para contar, y procurar contarla bien, es decir, con esmero en el lenguaje "porque será el buen uso de la lengua, no solamente la singularidad, la bondad o la oportunidad del tema, lo que va a preservar la obra del moho del tiempo" (Discurso Premio Cervantes). Postula, como su "imagen de escritor", un retrato de Honoré de Balzac escribiendo en camisón a la luz de una vela, "la imagen de un hombre solitario batiéndose con el lenguaje" (Doria 326).

La escritura de Marsé delimita un estilo propio y reconocible. Castillo observa que toda la obra de Marsé consolida un edificio, y las novelas mantienen una uniformidad lingüística que las hace distinguibles con facilidad (45). Esa uniformidad lingüística se caracteriza por la

\footnotetext{
${ }^{19}$ Marsé afirma, en la entrevista, que sus novelas se sitúan en Barcelona porque es el espacio que mejor conoce, haciendo gala de una de las reglas fundamentales de la estética realista: "Bueno, sencillamente porque he nacido aquí, me he criado aquí, he madurado aquí. He pasado mi infancia, mi adolescencia. Si hubiese nacido en otra parte, y hubiese crecido en otra ciudad, bueno, pues sería sin duda la otra ciudad. ¿Por qué? El escritor va a hablar de aquello que ha conocido más directamente" (124)
} 
preferencia por un lenguaje comprensible para la mayoría del público lector: "Sus novelas cada vez resultan más claras y accesibles, como si el escritor buscase una sencillez, una prosa diáfana con todos sus pliegues, que resume a la perfección su vocación de estilo" (Castillo 46). Marsé rehúye de lo que denomina "prosa sonajero", que "gusta mucho, porque suena muy bien, pero suena hasta tal punto que me impide la lectura, me molesta [... pues] si la escritura es demasiado ostentosa, es insoportable" (Guisasola 287).

La búsqueda de sencillez en el lenguaje consolida una escritura que fluye, con un ritmo a veces vertiginoso, en el que se ocultan las costuras del quehacer literario. El lenguaje de Marsé es expresivo, y muchas veces hace ceder al narrador su lugar de privilegio para que este rol sea asumido por el lector: el narrador, así, rehúye de las largas descripciones psicologistas, y no muestra explícitamente, sino que hace ver: "Yo no me conformo con escribir "es un avaro". No. Lo que quiero es hacerle ver al lector que ese personaje, sin decirlo directamente, es un avaro. En la buena literatura las cosas aparecen sin ser citadas” (Martí 12).

La claridad en el lenguaje se asocia también con el imperativo realista de verosimilitud. Marsé observa que cuando la prosa adquiere más relevancia que el tema, cuando la escritura deslumbra, el lector se distancia del texto (Samaniego 378). En un escritor "obsesionado por no aburrir" (Samaniego 377), la aspiración es la de la escritura invisible: "Yo aspiro a una escritura casi invisible, en la medida en que atrape al lector de tal manera que esté leyendo sin darse cuenta de que está leyendo [...]. A mí me molesta un poco que la prosa me salte a la cara y me quiera seducir. Quiero que me seduzca la historia" (Belmonte 25).

Es, además, un escritor profundamente visual (Mainer "Juan Marsé” 5). Hemos visto las influencias que el cine ha impreso en su estilo; de hecho, ocho de sus quince novelas fueron llevadas a la pantalla grande debido al potencial cinematográfico de su escritura. Mainer destaca la impresión de simultaneidad, la potencia del subrayado gestual en los diálogos que mantienen sus personajes y la composición de las escenas (5). El proceso de escritura de sus 
novelas comienza a partir de una imagen: "Inicialmente, siempre hay una imagen. Eso sí lo tengo claro. Yo parto, no de ideas, sino de imágenes; imágenes concretas que pueden ser, un recuerdo de la infancia que se me ha mitificado, recuerdos que he mitificado con el paso del tiempo" (Samaniego 376). Las descripciones físicas de sus personajes, por otra parte, son minuciosas y en orden, como si una cámara registrara las características de determinado actor subiendo, lentamente, de los pies a la cabeza. Cierta imaginería, además, enraizada en el estereotipo hollywoodense de los años 50 - la prostituta de lujo, el gángster- permite muchas veces retratos sucintos, impresionistas, que se asientan una apuesta por el reconocimiento, por parte del lector, de una figura ya introducida en su corpus de representaciones por la industria cinematográfica.

También del cine Marsé toma una manera particular de estructurar la trama; procedimientos literarios específicos asociados al montaje cinematográfico, por ejemplo, dan forma a la estructura de varias de sus novelas; el ejemplo más patente es Si te dicen que caí. Es muy frecuente, por otra parte, el recurso de la elipsis temporal, el "plano negro": "el narrador de Rabos de lagartija es un feto, es una cámara que lo registra todo, instalada en el vientre de su madre, pero que 'deja de filmar' cuando el inspector y la pelirroja entran en una habitación y la puerta se cierra tras ellos" (Ordóñez 104). Estos procedimientos, propios de la tradición clásica, ${ }^{20}$ se asocian, en primer término, con un cierto decoro al narrar. Sin embargo, también puede plantearse la potencialidad de este tipo de recurso elíptico, que opera convocando el poder creativo del lector.

Otra característica distintiva de la poética de Marsé es su categórico rechazo a imprimir en su escritura un cariz político: "Yo, como novelista, jamás me haré un planteamiento político; ¡como novelista! ... Si yo me hiciera planteamientos políticos serios, dejaba la pluma y cogía el fusil; pues muy bien, cojo la pluma; pero no quiero utilizarla como si fuera un fusil; la pluma

\footnotetext{
${ }^{20}$ En la tragedia clásica, lo "obsceno" es, precisamente, lo que se deja "fuera de escena".
} 
no dispara balas" (Vidal y Secorum 68). Si bien es cierto que su escritura no se condice con la del "intelectual comprometido" y su obra no ostenta un compromiso partidario, es innegable que su manejo del humor y de la ironía con fines de crítica social lo convierten en un escritor profundamente político. No es, entonces, un escritor partidario, aunque, por otra parte, afirma haber "mantenido siempre el sentido crítico" (Guisasola 284).

Mijail Bajtin ha señalado el poder transgresor de la risa, subversiva de la cultura oficial, seria, religiosa y feudal de la Edad Media. Para Bajtin, la risa carnavalesca propone un orden social otro, y por lo tanto subvierte el orden social impuesto (10). Aunque la influencia del carnaval es visible en la obra de Marsé-El amante bilingüe es el ejemplo más cabal de este influjo, aunque ciertos sectores de La oscura historia de la prima Montse también son permeables a una lectura desde esta perspectiva-resulta productivo recuperar las observaciones de Umberto Eco al respecto del estudio de Bajtin para profundizar en la operatividad política del humor en la obra de Marsé.

Eco registra que el concepto de carnavalización implica la parodia de ciertas reglas y rituales. Para que esta parodia sea efectiva, es decir, para lograr el efecto cómico, estas reglas y rituales deben ser reconocidos y respetados; para apreciar la transgresión de la norma, se debe sentir su dominio: "Sin una ley válida que se pueda romper, es imposible el carnaval” (16). Esto lleva a Eco a afirmar que la comicidad carnavalesca_-"lo cómico"— no es una instancia de transgresión real, sino que, por el contrario, es un ejemplo del reforzamiento de la ley, pues recuerda la existencia de esa regla que se está quebrando. A la idea de lo cómico, Eco opone el concepto de el humor. Para el semiólogo italiano, la diferencia entre estos conceptos radica en el hecho de que "lo cómico" refuerza la regla a base de quebrarla, mientras que "el humor" reconoce la imposibilidad de modificar cierta regla social, pero la hace visible y la pone en duda: “[E]l humor siempre es, si no metalinguiístico, si metasemiótico: a través del lenguaje verbal o algún otro sistema de signos, pone en duda otros códigos culturales" (19). Eco 
considera que la posibilidad de transgresión está en el humor, porque no pretende llevarnos más allá de nuestros límites, sino que nos muestra la estructura de esos límites para que, desde la identificación, nos riamos de nosotros mismos. Así, no se coloca—como lo cómico—fuera de los límites, sino que socava los límites desde dentro: "No busca una libertad imposible, pero es un verdadero movimiento de libertad. El humor no nos promete liberación: al contrario, nos advierte la imposibilidad de una liberación global, recordándonos la presencia de una ley que ya no hay razón para obedecer. Al hacerlo, mina la ley. Nos hace sentir la molestia de vivir bajo una ley, cualquier ley" (19).

La productividad política del humor corrosivo de Marsé se multiplica si se lo analiza desde esta perspectiva. Apela a la identificación, y pone de manifiesto lo ridículo de determinadas reglas sociales que, sin embargo, sabe que no puede transformar. Rosa Regàs registra esta característica del novelista catalán y afirma: "Marsé nunca utiliza el hacha para la crítica feroz, sino la ironía, a veces la compasión, tal vez porque su extraordinario talento le dice cuán inevitables son las actitudes menos encomiables. Reímos y lloramos y sonreímos y nos horrorizamos y nos emocionamos [...] [con] esa luz ácida pero benevolente que ilumina toda su obra" (124).

Marsé asevera: “Aprecio sobre todo la ironía. A veces hay que ser sarcástico, ir un poco más allá. A veces lo he sido” (Guisasola 284). A través de la identificación, despliega un humor corrosivo y ridiculizante sobre sectores políticamente definidos. El primero de estos sectores es la Iglesia Católica, de quien es un antagonista confeso: "Yo soy, como diría don Pío, anticlerical y anticura, la gente de sotana no me gusta nada. La historia de la iglesia en este país es tan siniestra que hay que tener mucho estómago para contemporizar con esta gente" (citado en Amell 90). Uno de los ejemplos más cabales de ridiculización de esta institución, que será revisado con profundidad en el tercer capítulo de esta tesis, se encuentra en la novela La oscura historia de la prima Montse. Este fragmento, denominado "Los misterios de colores", 
consolida una crítica tan poderosa y desopilante que dio lugar a una publicación como texto autónomo en 1993.

El segundo sector que prefiere la pluma corrosiva de Marsé es el de la burguesía catalana catalano-parlante. Antinacionalista convencido, ${ }^{21}$ parodia el discurso sobre la pureza de la catalanidad y pone de manifiesto su carácter excesivo. Marsé elige representar la catalanidad a partir de las clases altoburguesas a pesar de que la diversidad socioeconómica catalana es más compleja (de hecho, el propio Marsé proviene de una familia catalana de clase trabajadora). Esto ya fue observado por Resina, quien subraya que la ocultación de la clase trabajadora lleva paradójicamente a una identificación errónea de lo nacional catalán en términos de clase ("The Double" 99). Si bien es cierto, además, que un sector de las clases burguesas catalanas optó por una actitud pasiva durante el franquismo para salvaguardar sus intereses económicos, no deja de ser significativo que otro sector de este grupo fue quien se erigió como depositario y protector de la cultura proscrita, lo que llevó a la pervivencia de un nacionalismo clásico, afincado en una idea homogénea y excluyente de nación. Creemos que es este el sector que Marsé representa en su obra. Con ironía, elabora retratos de personajes altoburgueses catalanistas convencidos de una determinada versión de mundo, tan cerrados en su perspectiva que, por lo general, el desarrollo de la trama les pasa inadvertido. Los padres de Teresa (Últimas tardes con Teresa), la familia de Montse (La oscura historia de la prima Montse) y el personaje de Norma Valentí, junto con su núcleo social de amistades (El amante bilingüe) comparten una cortedad de miras que los enceguece frente a ciertos hechos que les incumben, una manera de interpretar que no habilita la posibilidad de considerar al otro—al no catalán, al no burgués. Afirma, con respecto a la situación actual, que Cataluña está viviendo

\footnotetext{
${ }^{21}$ En la entrevista a propósito del 40 aniversario de la publicación de Si te dicen que caí, afirma: "No soy nacionalista para nada, no milito bajo ninguna bandera, siempre recuerdo lo que dijo Flaubert: que están todas tan llenas de sangre y de mierda y que ya va siendo hora de acabar con ellas". Elige también esa cita como epígrafe para el primer capítulo de la cuarta parte de Un día volveré (1982): "Todas las banderas han sido tan bañadas de sangre y de mierda que ya es hora de acabar con ellas", Gustave Flaubert.
} 
una "especie de delirio identitario" (Guisasola 281). En su obra despliega, de hecho, una mirada burlona sobre los símbolos que representan "la pureza de la catalanidad": Griselda, por ejemplo, de El amante bilingüe, está convencida de que, dada la fama de Montserrat Caballé, la ópera debería cantarse en catalán. El humor, entonces, se configura como un rasgo general característico de la escritura de Marsé.

A través de las diversas características que hemos revisado en estas páginas, Marsé configura una poética particular, que se vincula de un modo preciso con la lengua y la nación catalanas. El presente trabajo se centrará en el análisis específico de tres novelas-Últimas tardes con Teresa (1966), La oscura historia de la prima Montse (1970) y El amante bilingüe (1990) — que delimitan una idea particular de nación para el caso catalán. Los veinticuatro años que separan a la primera novela de la tercera han sido, también, años intensos para la historia de España y de Cataluña, por lo que inevitablemente los contextos de producción y recepción de las novelas varían, nutriéndose de esos cambios históricos. Sin embargo, consideramos que puede leerse una construcción progresiva y coherente de un discurso nacional catalán a lo largo de esos años. Esta tesis apunta a explorar esta novedosa imagen de nación para el caso de Cataluña, prefigurada por Marsé a partir de tres tipos discernibles de estrategias lingüísticoliterarias. Denomino a estos tres tipos de estrategias "discursivas", "narrativas" y "lingüísticas", y creo que operan en el nivel de la construcción del texto como las tres hebras de una trenza, que se entretejen para dar lugar a un texto nacional catalán preciso (la palabra “texto", proviene, precisamente, del latín "textus", "tejido").

Las estrategias discursivas, en primer término, son visibles dentro del marco de la semiosis textual. Me abocaré, en este punto, a un análisis sintáctico, gramatical y léxico de ciertos sectores de la densidad textual. Algunos de los puntos que guiarán este examen serán, por ejemplo, la selección de determinados vocablos sobre otros posibles, o la preferencia, en determinados fragmentos, por tiempos verbales continuos o imperfectos frente a otros 
fragmentos de tiempos verbales perfectos. También se encuadrará dentro de este estudio la indagación sobre la abundancia de adjetivos calificativos en determinados momentos de la narración, frente a otros momentos de escueta prosa nominativa, o bien la introducción de determinados diálogos en lengua catalana. Estas estrategias, que construyen significados factibles de ser interpretados, se corresponden al nivel más textual del enramado narrativo.

En segundo lugar, denomino estrategias narrativas a las que se vinculan con el orden temático de la trama, personajes, espacios y símbolos. En este sentido, resulta imprescindible registrar la configuración de un personaje prototípico, el "charnego" (o xarnego, en catalán). Este término ha sido utilizado peyorativamente por algunos catalanes para referirse al inmigrante de una región española, de habla castellana. Esta ola inmigratoria proveniente, principalmente, de Andalucía y Murcia, acrecentó la población de Cataluña en más de un millón de personas en poco más de diez años, durante la década de los sesenta. El impacto de esta heterogeneidad dio lugar a numerosas negociaciones en los relatos nacionales e identitarios de Cataluña. La progresiva integración de esta figura en la narrativa de Marsé es quizás la piedra de toque de su construcción de un discurso nacional catalán de bordes difusos, heteróclito y plural, que apunta a abarcar a lo múltiple en su diferencia sin dejar de lado las tensiones y los conflictos que subyacen a ese proceso. Es en este sentido que puede plantearse que la definición de nación catalana que propone Marsé en su narrativa es una definición posmoderna, como veremos más adelante. Asimismo, considero también estrategias narrativas las diversas textualizaciones que Marsé presenta de "lo catalán", el boceto que el novelista prefigura de lo que tradicionalmente se ha considerado (y se considera), sin discusión, "lo Propio". Dentro de esta perspectiva, entonces, pueden enumerarse la inclusión de determinados espacios geográficos que configuran lo que el autor ha denominado "una Barcelona mental", la preferencia por determinados recorridos, la complementariedad u oposición de ciertos espacios cerrados, como la casona burguesa frente al cuarto de pensión o 
la casilla de la periferia. También se posiciona en este nivel de análisis el dibujo de determinados símbolos de lo nacional catalán: la textualización de ciertos partidos políticos o movimientos religiosos, la dramatización de determinados mitos nacionales, la referencia a símbolos históricos específicos, como la senyera (bandera de Cataluña) o algunos símbolos asociados al franquismo; o bien la presencia de la música popular y tradicional catalana en determinados fragmentos de la trama, asociada a determinados personajes. A través de estas estrategias, Marsé va corroyendo las fronteras fijas que separan lo Propio catalán de lo migrante, características del concepto clásico de nación, y permite leer una reelaboración de ese concepto, de fronteras progresivamente fragmentadas.

En tercer y último lugar, la estrategia lingüística es la que subyace a la elección de la lengua castellana como vehiculizadora del texto literario. Como veremos más adelante, la región autónoma de Cataluña ha sido históricamente un territorio en situación de diglosia, ${ }^{22}$ es decir, ha existido una situación relativamente estable de convivencia de dos lenguas: el catalán y el castellano. Argumentaremos que la elección de un castellano específico, localizado en Cataluña y profundamente interferido por el catalán, es un dato fundamental para la construcción de su idea de nación catalana de fronteras permeables, además de ser una opción táctica en cuanto a los alcances materiales de su mensaje, dado que el castellano—con 567 millones de hablantes ${ }^{23}$ _ es la tercera lengua más hablada del mundo.

Consideramos que estas tres estrategias operan en conjunto para delimitar una idea posmoderna de nación, más abierta y heteróclita, en el caso de Cataluña. En el próximo capítulo de este trabajo, recuperaremos brevemente los puntos destacados del discurso historiográfico sobre la formación y consolidación de Cataluña como nación específica. En este capítulo, también nos detendremos en la presentación del marco teórico que da cuerpo a nuestra tesis.

\footnotetext{
${ }^{22}$ Problematizaremos este término en el capítulo quinto de este trabajo.

${ }^{23}$ Según un informe del año 2016 del Instituto Cervantes.
} 
Examinaremos diversos aportes filosóficos, antropológicos y políticos para intentar delinear una definición posible del elusivo concepto de nación. Revisaremos, también, las relaciones entre lengua, nación e identidad, y analizaremos las ideas de bilingüismo y diglosia, y sus posibles aplicaciones al caso catalán. Registraremos, asimismo, diversas contribuciones filosóficas sobre el discurso de la posmodernidad, y sugeriremos una definición en clave posmoderna del concepto de nación. Finalmente, presentaremos la hipótesis principal de esta tesis: que Marsé diseña una idea posmoderna de nación catalana, fluida y de bordes fragmentados, que evoluciona en una línea coherente a lo largo del tiempo y de su producción literaria, y que se puede observar en tres de sus novelas.

El segundo capítulo de esta tesis se centrará en el análisis de la novela Últimas tardes con Teresa, ganadora del premio Biblioteca Breve en 1965 y publicada un año más tarde, en 1966. Ambientada en la Barcelona de los años sesenta, la novela narra una historia de amor entre una muchacha catalana de la alta burguesía, militante universitaria de izquierdas, y un seductor ladrón de motos y automóviles, inmigrante del sur de España. La escritura de la novela - en castellano- pone de manifiesto la presencia de la lengua catalana, como así también la de la jerga propia de los barrios bajos de Barcelona.

El tercer capítulo se abocará al estudio de la novela La oscura historia de la prima Montse, publicada en 1970. Esta novela, que se despliega en varios planos temporales, se centra en la historia de amor de una joven proveniente de la alta burguesía catalana, consagrada en la orden seglar de las Visitadoras de la Caridad, rama "progresista" de la Iglesia Católica, y un presidiario inmigrante, proveniente del sur de España. Este texto, cuya fecha de publicación se encuentra ya cercana al regreso de la democracia, registra un tono irónico, casi cínico, de crítica mordaz contra la burguesía y la iglesia.

El cuarto capítulo examinará la novela El amante bilingüe de 1990. Situada ya en el contexto democrático de la autonomía catalana, narra la historia de Juan Marés, quien, después 
de ser engañado por su mujer, entra en una vertiginosa decadencia que culminará con un cuadro de esquizofrenia. ${ }^{24}$ La novela se sitúa dentro del contexto del Plan de Normalización Lingüística, proyecto de recuperación del uso público del catalán llevado a cabo por el gobierno autonómico y describe con ironía mordaz la insistencia del nacionalismo catalán en imponer una lengua sobre otra en una población heterogénea.

Las tres novelas a considerar en este trabajo de investigación coinciden en la particularidad de haber sido escritas en castellano. Esto configura, a mi criterio, la estrategia lingüística de construcción de lo nacional catalán, transversal a toda la práctica escrituraria de Marsé. Es esta estrategia el tema principal del capítulo quinto de esta tesis. En este apartado, se realizará un análisis detallado de la lengua literaria de Marsé, lo que configura un aporte original al corpus de la bibliografía crítica sobre su obra. El autor afirma, en numerosas entrevistas, que su escritura en castellano responde a que ha sido ésta la lengua de sus influencias y de sus lecturas, debido a los cuarenta años de represión franquista sobre la literatura en catalán. De este modo, su producción se ubica en un lugar de borde: nacido y criado en el seno de una familia catalana, Marsé cuestiona y construye una imagen de nación catalana, aunque elige la expresión castellana para llevarla a cabo. Esta posición excéntrica, “de francotirador", pone en cuestión su pertenencia al circuito cultural catalán y español, en un lugar fronterizo. Finalmente, el sexto capítulo ha sido dedicado a la presentación de las conclusiones extraídas de este estudio, y a trazar posibles líneas de trabajo para futuras investigaciones.

En el próximo capítulo, entonces, se presentarán diversos aportes teóricos e historiográficos con el fin de articular nuestro análisis de las tres novelas de Marsé en un marco teórico-crítico extensivo. Revisaremos, entonces, los conceptos clave que darán espesor teórico

\footnotetext{
${ }^{24}$ Así se refiere Marsé, en numerosas entrevistas (Belmonte Serrano, Doria, Pérez), al trastorno psiquiátrico que afecta a Marés. No hay ninguna intención por parte del autor de usar la palabra esquizofrenia en un sentido clínico.
} 
a nuestro trabajo, e intentaremos articular estos aportes con una bibliografía crítica específica, en relación con el corpus de novelas a estudiar. 


\section{Capítulo 1}

\section{Historias, estados, nacionalismos e identidades}

Este primer capítulo del estudio presentará un resumen del contexto histórico pertinente al análisis de la idea de la nación catalana. A su vez, considerará ciertos aportes teóricos que darán cuenta de la pluralidad de perspectivas que rodean al elusivo concepto de nación. Dado que este análisis propone que las tres novelas seleccionadas presentan la evolución de un relato de nación cuyos bordes se van haciendo cada vez más difusos, resulta conveniente, entonces, rastrear los orígenes históricos de esa nación, y ver de qué manera se fueron cristalizando las definiciones de lo Propio para lo catalán.

Cataluña es un territorio de $32.000 \mathrm{~km}^{2}$, situado al noreste de la península ibérica, que limita al norte con Francia y Andorra, al este con el mar Mediterráneo, al sur con la Comunidad Valenciana y al oeste con Aragón. Sin embargo, el territorio catalán era, en la Edad Media, más amplio, definido por Rovira i Virgili a partir de un criterio lingüístico que incluía todos los territorios en los que se hablaba catalán. De este modo, la definición de lo catalán se extiende a las Islas Baleares, el Rosellón francés (en el departamento de los Pirineos orientales), la Comunidad Valenciana, una franja limítrofe de Aragón y un sector de la isla italiana de Cerdeña. Rovira i Virgili rastrea los orígenes de la lengua catalana-y, por lo tanto, del pueblo catalán, poniendo de manifiesto una tácita equivalencia entre nación y lengua ${ }^{25}$ —a los siglos V y VI, en los que el latín vernáculo comienza a derivar en esta lengua romance. Fija, además,

\footnotetext{
25 Andrés Barrera registra la operatividad de este criterio diferenciador incluso a nivel interno, distinguiendo acentos y variedades dialectales del catalán: "Son menos catalanas aquellas provincias, comarcas, áreas, etc. donde se han asentado más forasteros, inmigrantes, castellano-hablantes. Hablar más catalán, y de una manera que se supone más correcta, equivale a ser más catalán" (La dialéctica 156) (énfasis en el original). El etnolingüista agrega que durante su trabajo de campo registró que es la opinión general de que el catalán más "puro" (y, por lo tanto, la región más catalana) es el de la provincia de Gerona.
} 
una Edad Dorada de independencia: "No había terminado aún el siglo X cuando los condados catalanes dejaron de depender de los emperadores francos y tuvieron villa independiente. Primum inter pares, el condado de Barcelona obtuvo la hegemonía y constituyó el núcleo principal. El conde de Barcelona fue el príncipe de Cataluña” (31). El primer registro literario del catalán data del siglo XIII.

También Albert Balcells revisa los orígenes históricos del pueblo catalán y concuerda con el criterio lingüístico de Rovira i Virgili. Se detiene en la etapa histórica de asociación entre Cataluña y Aragón-la Confederación Aragonesa Catalana—, fruto de la unión dinástica entre la corona de Aragón y el principado de Barcelona en 1164, a partir de la cual se logró la anexión de numerosos territorios. La historiografía catalanista ${ }^{26}$ ubica el comienzo de la decadencia catalana en el siglo XIV, debido a la extinción de la dinastía catalana y la coronación de Fernando de Antequera, castellano y representante del absolutismo monárquico centralista. En 1469 se celebra el matrimonio de su nieto Fernando de Aragón con Isabel de Castilla, lo que es asumido como el momento definitivo de la subordinación de Cataluña a Castilla. La instauración de la corte en Castilla, por otra parte, sumada a la conquista de América y desplazamiento del foco portuario del Mediterráneo al Atlántico, dan la estocada final al orgullo catalán: la región, empobrecida, se ve atravesada por un sentimiento de provincialismo y decadencia, lo que genera que sus poetas abandonen el catalán y comiencen a escribir en castellano para ganar el favor de la corte. De este modo, la lengua catalana queda relegada al ámbito doméstico, mientras que la sociedad concuerda en el prestigio del castellano dominante. El último golpe a la autonomía catalana es el del Decreto de Nueva Planta (1716), que convierte al principado de Cataluña en una provincia de la Monarquía. Ambos

\footnotetext{
${ }^{26}$ Prat de la Riba, Rovira i Virgili, Balcells.
} 
historiadores coinciden en denominar "etapa de la decadencia" a la que se encuentra entre los siglos XVI y XVIII. ${ }^{27}$

El renacimiento catalán se sitúa en el siglo XIX, a partir de un florecimiento poético que afinca en el romanticismo alemán, en tanto recupera y revive el orgullo por lo popular y lo propio. Este momento de resurgimiento catalanista se denomina "Renaixença", y si bien en un principio es un movimiento de recuperación artístico-literaria de la música y de la lengua catalana, muy pronto se vuelve un movimiento político de reivindicación de lo catalán frente a lo español: "Con el tiempo, entre los literatos se iba acentuando la tendencia a convertir el renacimiento literario en un movimiento de reivindicación patriótica.” (Rovira i Virgili 122). El catalanismo, en sus comienzos, surge dentro de las clases sociales más favorecidas, como señala Jordi Casassas:

El catalanismo debió ser cosa de minorías cultas, políticas, con posibilidades de expresión institucional y directamente afectadas por la marcha de la modernización e institucionalización liberal del Occidente europeo: esta perspectiva nos retrotrae al grupo de intelectuales, profesionales liberales y líderes institucionales, periodísticos y de movimientos populares (Iglesia incluida), que son los que van debatiendo las propuestas, perfilando estrategias y fijando los utillajes y el vocabulario en relación [...] a la marcha política general española y a la dinámica occidental general. (17)

Aunque Rovira i Virgili concuerda con que el nacionalismo catalán fue, en un primer momento, cosa de burgueses y de clases altas, pues las clases trabajadoras eran básicamente anarquistas, también afirma que luego y lentamente, estas clases comienzan también a apoyar al movimiento federalista catalán (129).

\footnotetext{
${ }^{27}$ Siguán observa que es a partir de este momento que comienza a construirse la idea de nación española: "Hasta este momento, la progresiva pérdida de importancia de las lenguas diversas del castellano había sido una consecuencia secundaria de la política de unificación; a partir de este momento la uniformidad lingǘstica se convertiría en un objetivo directo, y esta uniformidad sería considerada [...] la expresión de la unidad nacional" (ctd en Mar-Molinero 22).
} 
Jordi Canal encuentra cuatro conjuntos de elementos que coinciden para dar lugar a los nacionalismos alternativos al español en la península ibérica. En primer término, alude a la existencia de una coyuntura propicia, dada por un ambiente de crisis económica y política, asociada a la pérdida de las colonias y a los cuestionamientos de los intelectuales (60). En segundo lugar, Canal registra un ambiente de descontento en relación con los proyectos tendientes a construir el Estado-nación español. Afirma que no es posible comprender los nacionalismos periféricos sin considerar el nacionalismo estatal, tendiente, en su proceso de construcción nacional, a "hacer españoles", es decir, "a nacionalizar una comunidad política preexistente" (61).

Resultan relevantes en este sentido los aportes del filólogo Joan-Lluís Marfany, quien observa que el nacionalismo catalán surge paralelamente al nacionalismo español, como respuesta a una ideología que pretende apropiarse de la particularidad catalana, y, en ese proceso, asimilar la "catalanidad" en un sentimiento nacionalista mayor, que le niega a esa nación su carácter específico. En este sentido, Marfany sostiene que el cariz político de la Renaixença tiene una relación directa con lo que el discurso historiográfico denomina "el desastre español”, es decir, la pérdida de las últimas colonias que España conservaba en América Latina (ctd en Ferré 218). Lo que el discurso historiográfico denomina "el desastre español" o "el desastre de 1898" se refiere al resultado de la guerra hispanoestadounidense, que se resuelve categóricamente a favor de Estados Unidos, debido a la superioridad en cantidad y en calidad de su armamento naval. Luego de su derrota, España fue forzada a firmar el Tratado de París el 10 de diciembre de 1898, que otorgaba la independencia a Cuba y entregaba las islas de Puerto Rico y Filipinas a los Estados Unidos (Shaw 1). Esta fecha se configura como el fin de la etapa imperial española.

Como indica Donald Shaw, la derrota es acogida por el pueblo español con bastante indiferencia, pero no tiene el mismo impacto en el circuito intelectual. Los intelectuales de la 
época-generalmente comprendidos bajo la categoría "Generación del 98"28_ofrecen una respuesta filosófica y abstracta al tema, que engendra, en algunos casos, un discurso nacionalista. Marfany, entonces, ubica el matiz político de la Renaixença catalana como una respuesta a este nuevo discurso expansionista, "y en absoluto reconocedor de la idea de plurinacionalidad. Por lo tanto, existirían catalanistas porque se articulaba simultáneamente un nacionalismo español” (ctd en Ferré 218). El filólogo registra que, una vez establecido el discurso nacionalista español, el discurso catalanista debe autolegitimarse, y, en esa dirección, ““inventa' una simbología y actividades formativas para legitimar una estrategia de afirmación de la identidad" (217). Borja de Riquer, por su parte, afirma que los nacionalismos periféricos no son los responsables de socavar la unidad española, sino que el proceso es a la inversa, fue la ineficacia de la acción unificadora del Estado, sumada a los desequilibrios económicos internos - sobre todo entre Cataluña y el País Vasco, y el resto-y la falta de homogeneidad social lo que dio lugar al surgimiento de los nacionalismos intraibéricos (ctd en Canal 61).

Casassas concuerda con esta perspectiva, pero insiste en el hecho de que el nacionalismo catalán se fortalece con el desastre español, aunque surge antes. Se refiere a la Exposición Universal de 1888, evento de relevancia internacional a nivel político, social y económico que se llevaba a cabo con cierta periodicidad en distintas ciudades del mundo con el fin de que cada país expusiera sus avances tecnológicos y su potencial económico e industrial. El hecho de que la ciudad elegida para la exposición fuera Barcelona no es menor, y, para Ymbert, este evento “desemboca en la necesidad de institucionalización y politización que se fija en la redacción del programa primigenio de las Bases de Manresa (1892)" (Cassasas 17). En 1889, las dos asociaciones tradicionalistas principales (la Lliga de Catalunya y el Centre Escolar Català) llevan a cabo una serie de reuniones en distintos lugares de Cataluña

\footnotetext{
${ }^{28}$ No presentaremos en esta tesis las diversas controversias con respecto a las categorías historiográficas que se refieren al modernismo español. Baste mencionar que la crítica ha encontrado numerosas dificultades para establecer los límites generacionales de este grupo intelectual, y que las etiquetas de "generación del 98" y "modernista" han sido objeto de numerosas polémicas en la Academia y en el discurso histórico-literario.
} 
para promover el derecho civil catalán. Las relaciones que se establecieron en esta campaña favorecieron la creación, en 1891, de una confederación de centros catalanistas, que tomó el nombre de "Unió Catalanista". En su segunda asamblea anual, en 1892 en la ciudad de Manresa, provincia de Barcelona, la Unió aprobó las Bases para la Constitución Regional Catalana - conocidas como las "Bases de Manresa"-, "una especie de primer proyecto de estatuto de autonomía para Cataluña" (Balcells 63). Las bases planteaban la necesidad de hacer oficial la lengua catalana en Cataluña, y de centralizar las finanzas, el poder tributario y el control del orden público en el gobierno local. Fueron tachadas de separatistas, e ignoradas por el poder central (64).

Canal encuentra un tercer grupo de factores que favorecieron el surgimiento del nacionalismo catalán en la presencia de "tradiciones, conciencias, realidades, experiencias y signos identitarios más o menos antiguos. Entre éstas y éstos sobresalen la lengua [...] una cultura y una historia propia, lealtades institucionales y tradiciones jurídicas locales y regionales" (62) además de, en algunos casos, como en el vasco, una conciencia étnica diferenciada. También en este grupo de factores, Canal articula la diversidad de realidades socioeconómicas, en tanto regiones como Cataluña o Euskadi transitaban un proceso de industrialización que el resto de España, no: “Aunque toda nación y todo nacionalismo sean una construcción, ${ }^{29}$ no sería posible emprenderla sin unas sólidas bases, sin materiales" (62). Finalmente, Canal sostiene que el cuarto grupo de factores para la constitución de los nacionalismos disidentes al español se vincula con los actores (políticos, intelectuales, líderes) (62). En este sentido, resulta relevante destacar la potencia de los intelectuales de la Renaixença, que no tuvo una respuesta estatista a su altura.

A pesar de las sutiles diferencias cronológicas, el discurso historiográfico coincide en señalar el surgimiento del nacionalismo catalán—o catalanismo — a fines del siglo XIX. Ahora

\footnotetext{
${ }^{29}$ Nos detendremos en esto más adelante en este capítulo.
} 
bien, aunque el catalanismo de la época coincide en el orgullo por lo catalán, y en la necesidad de una mayor autonomía con respecto al poder central, no está representado por una línea teórica sólida, sino que también presenta sus tensiones y fracturas. En 1901, una minoría de intelectuales — como Prat de la Riba, Verdaguer i Callís, Cambó, y Puig i Cadafalch—se separa de la Unió Catalanista y funda el Centre Nacional Catalá. Apenas antes de las elecciones generales de 1901, esta institución se asocia con la Unión Regionalista, que había quedado relegada en un segundo plano por haberse negado a participar de la Unió. La fusión de la facción disidente de la Unió Catalanista con la Unión Regionalista dio lugar a la Lliga Regionalista de Catalunya, de tinte conservador y nacionalista, pero no independentista. Con el apoyo del partido republicano, la Lliga Regionalista logra una victoria rotunda en las elecciones de 1901, lo que significa el ocaso de la Unió Catalanista, que "subsistiría como asociación histórica pero apolítica del nacionalismo catalán” (Balcells 72). A principios del siglo XX, la Lliga Regionalista de Catalunya promueve la instauración del Cant dels Segadors, una canción popular de la Cataluña campesina, como "himno nacional", y la conmemoración del 11 de septiembre de 1714 — fecha en la que las tropas de Felipe V ocuparon Barcelonacomo símbolo movilizador (Balcells 75). Tanto la canción como la fecha patria son inmediatamente adoptadas por el pueblo catalán. De hecho, el Estatuto de Autonomía de Cataluña de 2006 declara: “Cataluña, definida como nacionalidad en el artículo primero, tiene como símbolos nacionales la bandera, la fiesta y el himno". El himno es el Cant dels Segadors; la fiesta, el 11 de septiembre.

El republicanismo que había apoyado a la Lliga Regionalista comienza, hacia 1903, a distanciarse debido a su conservadurismo. Liderados por Alejandro Lerroux, los republicanos comienzan a captar el apoyo de los sectores obreros catalanes, que no eran integrados por el oficialismo: "Si el catalanismo político a principios de siglo no atrajo a los obreros, no fue porque estos compartiesen cierto nacionalismo español ni un cosmopolitismo apátrida de 
inspiración ácrata-muy pocos eran anarquistas y menos aún socialistas—, sino porque el catalanismo de la Lliga Regionalista nada hacía ni decía que pudiese atraerlos” (Balcells 77). El republicanismo cobra fuerza y gana las elecciones generales en la ciudad de Barcelona, aunque no logra mayoría en Cataluña. Se consolida, de este modo, como una fuerza de relevancia opositora a la Lliga.

En 1906, la Lliga Regionalista se asocia con una facción republicana (disidente de Lerroux) y con otros grupos menores y forma la Solidaritat Catalana. La coalición electoral surge como respuesta a la Ley de Jurisdicciones, promulgada en 1906, que ponía bajo jurisdicción militar cualquier tipo de ofensa a los símbolos patrios españoles (la unidad de la patria, la bandera, los símbolos y el ejército nacional). Frente a la promulgación de esta ley, se da una reunión masiva de protesta en la Plaza de las Arenas de Barcelona, que consolida la Solidaritat. Esta asociación es considerada la primera asociación catalanista masiva: "Por primera vez, el catalanismo había podido llenar una plaza de toros, era ya un movimiento de masas" (Balcells 85). Borja de Riquer también destaca la relevancia de la Solidaritat para el catalanismo, y afirma que luego del triunfo de la Solidaritat en las elecciones generales de abril de 1907 (en las que obtuvo 41 de los 44 escaños que correspondían a las provincias catalanas), "ya nada sería igual en la vida política catalana, y los gobiernos de Madrid, y la propia corona, deberían asumir el hecho de que la cuestión catalana se había convertido en uno de los problemas más preocupantes de la vida política española” (52). Una de las primeras gestiones de gobierno de la Solidaritat es la creación del Institut d'Estudis Catalans, destinado no solamente a la investigación científica sino, sobre todo, a la normativización de la lengua catalana escrita. Balcells destaca que, por primera vez en la historia, una corporación política dedicaba recursos públicos a la alta cultura catalana (88).

La heterogeneidad presente en la Solidaritat lentamente comienza a erosionar los cimientos de la agrupación. Ciertas decisiones del poder central promueven un clima de 
inestabilidad política ${ }^{30}$ que consolidan la crisis de la Solidaritat. Después de un período de inestabilidad institucional, “en mayo de 1911, la Diputación Provincial de Barcelona propone la confección de unas bases para una mancomunidad de las cuatro provincias de Cataluña" (Balcells 101). Debido a ciertos contratiempos, la constitución formal de la Mancomunitat de Cataluña toma más tiempo del esperado, pero finalmente se constituye a principios de 1914 . Se establece, asimismo, una asamblea legislativa formada por la suma de los diputados de las cuatro provincias catalanas. "Aunque la Mancomunitat tenía sólo un carácter administrativo, constituía el primer reconocimiento de la personalidad de Cataluña" (Balcells 105). La gestión de la Mancomunitat no logró la cooficialidad del catalán, pero logró importantes avances en materia lingüística, en tanto convirtió a la lengua catalana en el idioma público y administrativo de la asociación. La Mancomunitat logra la normativización de la lengua catalana escrita, lo que la convirtió en un idioma comercial y técnico, y también estimuló la creación de un mercado cultural integrado en Cataluña (Balcells 106). Para la estandarización de la lengua, se tomó el modelo propuesto por el ingeniero industrial y lingüista, Pompeu Fabra i Poch. La Mancomunitat también destinó recursos a la industria cultural, la prensa y la educación con el fin de propagar la lengua catalana normativizada entre todos los habitantes de las cuatro diputaciones.

En 1923, se instaura en España la dictadura de Miguel Primo de Rivera, frente a un marco de crisis económica, vinculada con la mala administración estatal, pero también con los efectos devastadores de la Primera Guerra Mundial en el continente europeo. El gabinete militar lleva a cabo una serie de decretos que prohíben el uso de la lengua catalana, pero, como logra un crecimiento económico de relevancia, gana el apoyo de gran parte de la burguesía catalana, fuertemente empobrecida por la crisis económica anterior (Balcells 123). En enero de

\footnotetext{
${ }^{30}$ La Semana Trágica, en 1909, es quizás el hecho histórico más relevante. Comenzó con una huelga general como medida de resistencia frente a la obligación de enviar a Melilla tres levas seguidas de Barcelona, con reservistas casados y con hijos. La huelga pronto derivó en la quema de iglesias y escuelas católicas, lo que fue fuertemente reprimido por el gobierno central.
} 
1924, Primo de Rivera interviene en la Mancomunitat, impone nuevas reglas y genera, con estos cambios, la dimisión de gran parte de los dirigentes catalanes, que son reemplazados por funcionarios afines al régimen. La represión de la utilización pública de los símbolos catalanes lleva luego a su privatización, y queda en manos del otro sector de la burguesía, de sesgo catalanista. Balcells observa que esta represión funcionó como un factor de unidad para el pueblo catalán, que pudo identificarse como tal sin marcas partidarias (127). En enero de 1930, Primo de Rivera renuncia a su puesto por razones de salud y, después de un breve período de inestabilidad política, las elecciones municipales llevan a una victoria republicana el 12 de abril de 1931. Es así como a partir de 1931 España se convierte en la Segunda República Española, y el rey Alfonso XIII es forzado al exilio. Niceto Alcalá-Zamora es electo como líder provisional, y gobierna hasta la elección de Manuel Azaña, su sucesor.

En junio de 1931, luego de las elecciones en las que el republicanismo resultó vencedor, el Parlamento redacta una nueva constitución, que entra en efecto en diciembre de ese año. Esta constitución incluye la posibilidad de un Estatuto de Autonomía para Cataluña, que se instaura en la región en 1932. El nuevo Estatuto reconoce la cooficialidad de la lengua catalana y otorga a la Generalitat, el gobierno local catalán, la exclusiva legislación en derecho civil catalán, administración local y régimen administrativo interno, por lo que se lleva a cabo, en 1936, una nueva distribución territorial. También se le otorga al gobierno autonómico la facultad de administrar justicia y la obligación de llevar a cabo las obras públicas necesarias (Balcells 141).

El gobierno republicano, sin embargo, no logra resolver los conflictos sociales en España, y la polarización política, la violencia social y la inestabilidad continúan. La feroz oposición monárquica comienza a fragmentar la república a nivel institucional, y las tensiones políticas y sociales se tornan cada vez más fuertes. El 17 y el 18 de julio de 1936, una facción del ejército español intenta un golpe de Estado que es resistido por el gobierno republicano. Frente al fracaso de la toma del gobierno central, la facción rebelde, apoyada por la Alemania 
nazi y la Italia fascista, comienza la progresiva ocupación del territorio desde Melilla, ciudad autónoma española situada en el norte de África y da lugar al comienzo de la Guerra Civil Española. Durante la Guerra Civil (1936-1939), Cataluña se configura como el gran centro de resistencia republicana frente a los embates del franquismo. Debe crear su propio aparato de guerra, improvisar una industria bélica y organizar la resistencia de la república (Balcells 173). En un primer momento, la capital de la República Española se organizó en Valencia, pero en octubre de 1937 se trasladó a Barcelona, mejor preparada para la resistencia (Balcells 174). Milicianos españoles y de otras regiones de Europa y del mundo se trasladan a Barcelona para defender al gobierno legítimo. Sin embargo, no es suficiente: el 15 de enero de 1939, Tarragona (ciudad situada a $100 \mathrm{~km}$. al sur de Barcelona) es ocupada por el franquismo. Frente a la inminente derrota, el gobierno republicano ordena la retirada hacia la frontera francesa (Balcells 177). El 26 de enero de 1939, cae Barcelona.

La dictadura de Franco impone una represión cultural sin precedentes en Cataluña. Se prohibe el uso público de la lengua catalana — con algunos momentos de distensión, en los que se publican libros y prensa en catalán, aunque siempre sujetos a censura-y se suprimen los símbolos nacionales. El hecho de que Barcelona hubiera sido el gran foco de resistencia republicana durante la guerra civil española se paga caro: Cataluña, junto con el País Vasco, configuran los territorios más perseguidos y reprimidos por la dictadura franquista. Alrededor de 60.000 catalanes deben exiliarse sobre todo en Francia y en América Latina, y desde allí llevan a cabo gran parte de la resistencia de la cultura y de la lengua, ya que quienes se quedan son vigilados $\mathrm{y}$, muchas veces, asesinados por el régimen. Algunas de las primeras medidas del franquismo son el fusilamiento de más de 3.800 catalanes —algunos de ellos, aniquilados sólo por usar su lengua-y la expulsión de más de 25.000 de empleados públicos de las instituciones gubernamentales y de maestros y profesores universitarios, que son reemplazados 
por profesores castellanos (Balcells 181). Este proceso, llevado a cabo no sólo en Cataluña sino en todo el territorio español, se conoce como "depuración".

Hacia los años 50, la oposición al franquismo parece agotada debido a la dureza de la represión y a las dificultades internas para generar un acuerdo de acción de resistencia. En este sentido, el catolicismo colabora en la recuperación de la identidad catalana. Es la iglesia el ámbito donde la lengua catalana hace su reaparición como lengua pública. Dentro de esta perspectiva, surge un nuevo catalanismo, de fuerte impregnación católica, que rechaza el catalanismo republicano por anticlerical (Balcells 188). A mediados de los años 50 y durante toda la década del 60 se da un nuevo marco de desarrollo económico, lo que genera un fuerte aluvión inmigratorio proveniente del sur de la península, reflejado en Últimas tardes con Teresa (1966). La oscura historia de la prima Montse (1970), segunda novela a considerar en este estudio y situada históricamente a fines de los años 50, registra en clave irónica la acción de los movimientos catalanistas católicos, como así también la incorporación del migrante al escenario local.

La ola inmigratoria que llega a Cataluña entre fines de los 50 y mediados de los 70 es recibida con desprecio por la población catalana, que ve amenazada su-ya reprimidaidentidad nacional específica. Montserrat Clua observa que esta es una de las olas inmigratorias más importantes de la historia de Cataluña: “[E]ntre 1960 y 1975 llegaron aproximadamente millón y medio de personas [...] [que] se concentraron en los suburbios urbanos y las ciudades industriales cerca de Barcelona, creando una zona metropolitana de barrios masificados con una mayoría de población inmigrante de clase obrera" (“Catalanes" 66). El impacto del aluvión inmigratorio fue rotundo, pues llegó a representar el 75\% del crecimiento total de la población catalana (“Catalanes" 63).

Esta población, que propicia la mano de obra necesaria para el proceso industrializador de Cataluña, no es bien recibida por el pueblo catalán que acuña el término peyorativo 
"xarnego" (charnego) ${ }^{31}$ para designar a los recién llegados. Como subraya Clua, es un vocablo despectivo utilizado por los catalanes para designar "a un colectivo que, aunque procedente de una migración interna española, se considera extranjera en términos de nación catalana" (“Catalanes” 58). Andrés Barrera añade que, en la percepción de la población nativa, la inmigración se registra como una degradación de la catalanidad, que además amenaza la catalanidad de los locales, expuestos al contacto y a la interacción con personas de otra lengua. En su trabajo de campo, registra que la población rural se considera "más catalana" que la barcelonesa, pues “el contacto con los 'castellanos' inmigrantes los hace sospechosos de 'xarneguidad', algo mezclado, impuro, ambiguo". Añade que el hecho de que las comarcas rurales hayan permanecido cerradas, e impermeables a las influencias externas, es valorado de forma positiva por los locales (157).

Dentro del contexto del franquismo, la nueva población castellano-parlante es percibida por un sector importante de la población catalana como una amenaza a la estabilidad lingüística del catalán en la región. Balcells, de hecho, cita el registro del Boletín de Orientación bibliográfica del Ministerio de Información y Turismo de enero de 1968: "El franquismo confió en que la inmigración sería un instrumento involuntario para acabar de romper las tradiciones asociativas y reivindicativas de la clase obrera catalana y para realizar una castellanización por abajo, progresiva y constante, acompasada al ritmo expansivo de la industria e impulsada por diferentes índices de natalidad" (213). Lo cierto es que, como indica Clua, hubo una serie de

\footnotetext{
${ }^{31}$ Etimológicamente, la palabra deriva de "lucharniego"- - término a su vez resultado de una disimilación de un anterior "nocherniego" o "nocharniego", es decir, "que sale de noche"-, nombre que recibía una raza de perros entrenados para cazar por la noche. El término pasó a través de Cataluña hacia Francia con el significado de "raza de perro". Posteriormente en Francia la palabra gascona "charnègo" adquirió su primera connotación negativa, utilizada en el sentido de "mestizo, bastardo, no autóctono". Se utilizaba para hacer referencia principalmente a la población bilingüe que vivía en la frontera francoespañola. Con este sentido volvió a Cataluña en el siglo XIX, para denominar a los descendientes de matrimonios mixtos entre catalanes y no-catalanes, es decir, al resultado de la mezcla entre individuos de distintas nacionalidades y orígenes culturales. En los años 60 y 70, el término adquirió un sentido claramente discriminador, ampliando su capacidad descriptivo-categorizadora hasta integrar a los inmigrantes castellano-hablantes y sus descendientes en general, aunque no procedieran de matrimonios mixtos. El término se extendió para denominar a las personas de habla castellana residentes en Cataluña, que se consideraban no adaptadas lingüísticamente a la tierra de acogida porque no hablaban el catalán (Clua "Catalanes" $67)$.
} 
factores determinantes para que no se diera la incorporación de la lengua catalana por los migrantes como el contexto político de persecución de lo catalán, y la falta de espacios comunes de interacción entre migrantes y locales para aprender una lengua que estaba relegada al ámbito doméstico. Otro factor esencial que contribuyó a esta situación de desarticulación fue la convicción de los recién llegados de que, por encontrarse dentro de España, no había inconvenientes en hablar en castellano. Esto ha sido considerado por muchos locales como una falta de interés en la cultura local, lo que ha contribuido a la consolidación de un discurso xenófobo contra los inmigrantes y sus familias (Clua "Catalanes" 67).

Por otra parte, resulta imprescindible mencionar que los sectores migrantes castellanohablantes representan los sectores más bajos de la escala social, debido a su falta de instrucción (muchos de ellos eran, de hecho, analfabetos). Frente a esta realidad, el hablar en castellano (ya de por sí percibido negativamente en Cataluña, asociado al franquismo y a la represión) se articula con un significado social relativo a la falta de educación y a lo vulgar. En este sentido, hablar en catalán cobra en este momento jerarquía en términos de cultura y refinamiento, en tanto permite diferenciarse de los sectores más bajos de la pirámide social. La lengua se transforma entonces en un símbolo que condensa el prestigio social, o el descrédito del grupo parlante. Asimismo, se integran nuevas significaciones negativas sobre el castellano: no sólo es la lengua de los represores, sino también de los sectores sociales más incultos en la sociedad regional (Barrera La dialéctica 321).

Gran parte de la población catalana consolida, además, una resistencia frente a la represión del régimen de Franco. Entre 1962 y 1975 Balcells encuentra tres grandes actores de resistencia: el movimiento estudiantil—la población estudiantil de la Universidad de Barcelona se duplica entre 1962 y 1968 (219)—, el obrero y la organización catalanista Assemblea de Catalunya. Los comunistas y socialistas catalanes reivindican su papel como representantes del único catalanismo popular y auténtico, y el de actuar como puente con la inmigración obrera 
para evitar el peligro de la división del país en dos comunidades contrapuestas (Balcells 193). Es este el contexto de Últimas tardes con Teresa (1966), la menos reciente de las novelas que estudiaremos, donde se observa el primer registro de la figura del inmigrante del sur en la narrativa de Marsé. La novela presenta, además, una mirada cínica sobre la inocencia del cuadro comprometido que los estudiantes catalanistas, todos de procedencia burguesa, dibujaban sobre el grupo obrero, en su mayoría inmigrante y de poca formación.

Con la muerte de Franco y el inicio de la transición hacia la democracia en 1975, Cataluña gana terreno, al principio simbólico y luego material, a favor de la recuperación del autogobierno; en 1977 se reestablece la Generalitat, órgano autonómico de gobierno. En 1978 se introduce la enseñanza obligatoria de catalán en las escuelas y se acuerdan los primeros traspasos de competencias del Estado a la Generalitat. La Constitución española de 1978 reconoce el Estado de las Autonomías, "más cerca del modelo unitario descentralizado que del modelo federal, que era el preferido por los partidos catalanistas" (Balcells 237). Se logra la cooficialidad de la lengua catalana, aunque se pedía la oficialidad exclusiva y se traspasan las competencias de educación, conservación del orden público y administración. En 1980, Jordi Pujol gana las elecciones para presidir la Generalitat, ${ }^{32}$ en un marco de crisis económica, conspiraciones militares y terrorismo. A mediados de los 80, España se encuentra en plena crisis financiera, pero Cataluña crece (Balcells 247). Paralelamente, comienza a verbalizarse un reclamo histórico con respecto a la lengua que, aunque no exclusivamente, opera casi como una metonimia del concepto de "nación catalana". El reclamo de los catalanistas argumenta que, mientras que en Cataluña el conocimiento del castellano es un deber, el del catalán es sólo un derecho: el bilingüismo sería equilibrado si los castellano-hablantes fuesen bilingües en la misma proporción que los catalano-hablantes (Balcells 263).

\footnotetext{
${ }^{32}$ Jordi Pujol i Soley, presidente de la Generalitat entre 1980 y 2003, es considerado uno de los principales líderes del nacionalismo catalán en los últimos treinta años del siglo XX. Como indica Fainé, Pujol promovió un discurso integrador de la inmigración española en Cataluña ("Catalanes" 68), reflejado en su célebre sentencia: "Es catalán quien vive y trabaja en Cataluña y quiere ser catalán".
} 
El tema de la lengua, central en las negociaciones identitarias de lo nacional, da lugar al primer "Plan de normalización lingüística", tendiente a recuperar el uso público de la lengua catalana. El plan, asociado a la Ley de Normalización Lingüística de 1983, apunta a instaurar el catalán como lengua oficial en Cataluña: se enseña catalán en las escuelas, se difunde por los medios masivos de comunicación, de hecho surgen los canales de radio y televisión exclusivamente en catalán, además de material fílmico y una literatura específica vinculada con un sistema institucionalizado de premios literarios a las obras escritas en catalán. ${ }^{33}$ También se exige a los propietarios de comercios que sus carteles indicadores estén escritos en catalán y se difunden con énfasis las canciones cuyas letras están escritas en catalán, entre otras acciones reparadoras (Balcells 265). En este marco histórico se sitúa la novela El amante bilingüe, en la que se observan las insistentes medidas de "catalanización" de los segmentos demográficos no nativos, representados por los inmigrantes del sur de España y, ya en este momento histórico, a veces por sus hijos. Las líneas ideológicas subyacentes a las campañas de normalización lingüística no son bien recibidas por todos los habitantes de Cataluña, como puede comprobarse en el "Manifiesto por la igualdad de los derechos lingüísticos en Cataluña" (Diario 16, Madrid, 12 de marzo de 1981), en el que "un grupo de 2300 intelectuales y profesionales que viven y trabajan en Cataluña" critican la política de la Generalitat, pues consideran que no tiene en cuenta la complejidad lingüística y social de Cataluña. Consideran, además, que la normalización lingüística es tan coercitiva como ha sido la represión de lo catalán por el franquismo, y apuntan a construir, entre todos, una Cataluña más plural y democrática (Barrera La dialéctica 338).

En 1992, España ingresa en la Comunidad Europea, y comienza un nuevo aluvión inmigratorio en Cataluña. Los nuevos migrantes son de procedencia extracomunitaria,

\footnotetext{
${ }^{33}$ En 1936 se publicaron 865 libros en catalán; ese número logró ser superado recién en 1977 (Hout-Huijben 13).
} 
principalmente proveniente del África musulmana y de América del Sur. Esta oleada migratoria se encuentra aún en desarrollo, y ha generado también un impacto sobre la situación lingüística de la región. Los efectos de esta oleada migratoria a nivel lingüístico son diferentes a los de la de mediados del siglo XX, debido al importante porcentaje de migrantes que no dominan ni el castellano ni el catalán.

Cataluña transita hoy un período de inestabilidad política, que se vincula con una controvertida declaración de independencia, fuertemente reprimida por el gobierno central del ex primer ministro Mariano Rajoy y rechazada por gran parte de la población catalana. Tanto Francesc de Carreras como Canal ubican las raíces de este conflicto en el proceso de construcción de lo nacional llevado a cabo, en primer lugar, por Pujol, pero también por sus sucesores (Maragall, Montilla, Mas y Puigdemont) una vez lograda la autonomía. Carreras considera que la línea ideológica de la Generalitat fragmentó a la sociedad, reduciéndola a “catalanistas y españolistas. No existe el término medio: o eres catalanista, o eres españolista" (29). Canal, por su parte, registra también que la línea ideológica a la que se han adscripto los líderes de la Generalitat es nacionalista, en tanto "ha definido Cataluña como una nación, y España como un estado: lo natural frente a lo artificial" (66). Añade que todo nacionalismo apunta a la coincidencia entre estado y nación, por lo que no es llamativo que el nacionalismo de la Generalitat se haya tornado cada vez más secesionista. Canal sostiene que el proceso de nacionalización llevado a cabo por el pujolismo ha sido sumamente exitoso, y no solamente ha logrado instalar una lengua y una cultura nacional, sino que también ha articulado esta simbología con frases hechas, incuestionables, como "la culpa es de Madrid, la política catalana es diferente-el mito del oasis_-, Cataluña es más moderna (o más europea), Cataluña mantiene a otras regiones o, entre otras, no se reconocen los derechos nacionales de Cataluña", que "no se pronuncian para ser comentadas o discutidas, sino como una letanía reafirmante" (67). 
Los gobiernos nacionalistas de la Generalitat, coinciden Carreras y Canal, propusieron un nuevo estatuto de autonomía "innecesario, excepto para los propios intereses partidistas" (Canal 69), que produce "un notable trasvase del autonomismo al independentismo" (Carreras 35). Algunos autores consideran que la ciudadanía es movilizada por la vía de la crispación y la defensa de la patria amenazada (Canal 69) para apoyar el Estatuto, mientras que otros observan que para 2005 el sentimiento independentista no era aún mayoritario, pero sí comenzaba a percibirse un descontento cada vez mayor con el gobierno central debido a la "persistente situación de déficit fiscal de Cataluña (respecto a otras regiones españolas) con los efectos de la crisis económica" (Clúa i Fainé, "Identidad” 86), lo que contribuyó a generar una voluntad de romper con el estado español. Finalmente, el estatuto es aprobado por el gobierno local en 2005, aunque con un alto porcentaje de abstención. El 31 de julio de 2006, el Partido Popular español presenta ante el tribunal constitucional un recurso de inconstitucionalidad contra el nuevo estatuto; y la sentencia del tribunal lo declara inconstitucional, lo que, sumado a la demora en llegar a una sentencia, es percibido por el nacionalismo catalán como una afrenta (Canal 69). El sentimiento de frustración e indignación dio lugar a distintas campañas y movimientos nacionalistas que "han consolidado el discurso de 'defensa de la lengua, la cultura y la dignidad catalana' ante lo que denominan los múltiples 'ataques recibidos de España"” (Clua "Identidad" 92).

Las campañas más importantes han sido las “consultas soberanistas”, que promovieron la realización de diversos referéndums locales sobre la fundación de un estado catalán independiente dentro del contexto europeo. Estas consultas no tenían valor legal, sino consultivo y simbólico, y movilizaron a un $20 \%$ de la población votante, con un resultado de un $91.74 \%$ de los votos afines a la independencia. Este referéndum, llevado a cabo entre los años 2009 y 2011, no sólo hizo visible la voluntad secesionista de un sector de la población catalana, sino que situó la cuestión de la independencia en el centro de su agenda política (Clua 
"Identidad" 92). El proyecto independentista se fortalece, además, con un contexto desfavorable en el territorio español, golpeado por numerosos casos de corrupción, crisis económica y social y desempleo. El Barómetro de Opinión Pública del Centro de Estudios de Opinión de la Generalitat muestra que, para fines de 2012, la voluntad independentista había crecido notablemente: estable en alrededor del $15 \%$ entre 2005 y abril de 2009 , se incrementa sostenidamente entre abril de 2009 y junio de 2011 (cuando llega a un 25\%) y aceleradamente desde entonces, alcanzando el 34\% en junio de 2012 (Clua, "Identidad" 84-5). Si bien estos datos provienen de estudios llevados a cabo por el gobierno autonómico, el posterior desarrollo de los acontecimientos da cuenta de un crecimiento sostenido en la voluntad secesionista de parte de los habitantes de Cataluña.

En 2016, asume la presidencia de la Generalitat Carles Puigdemont, quien convoca a un referéndum de autodeterminación el 1 de octubre de 2017. La única pregunta de la consulta popular es: “¿Quiere que Cataluña sea un Estado independiente en forma de república?”. El gobierno de Madrid se opone violentamente a la votación, pero las autoridades catalanas lo desoyen y llevan a cabo la votación a pesar de los reclamos estatistas, que se amparan en la cuestión de la soberanía nacional española. Con una fuerte presencia de la guardia civil, que reprime a los votantes y quema urnas el día de la elección, el recuento irregular de votos registra que, del $43.03 \%$ del padrón que efectivamente votó, un $90.18 \%$ lo hizo a favor de la independencia. ${ }^{34}$ En un marco de inestabilidad política e ilegitimidad institucional, Carles Puigdemont proclama unilateralmente la independencia de la República de Cataluña el 10 de octubre de 2017. Sin embargo, suspende los efectos de la declaración por algunas semanas, apuntando a negociar una salida legítima del estado con el gobierno central. La declaración de independencia es respaldada el 27 de octubre por 70 votos a favor en el Parlament, 2 en blanco y 10 en contra, aunque esa sesión no cuenta con la presencia de los grupos parlamentarios del

\footnotetext{
${ }^{34}$ Datos de la Generalitat de Cataluña, sin verificación por un organismo neutral.
} 
Partido Socialista Español, del Partido Popular Español y de Ciudadanos, que consideran la votación ilegal.

El 28 de octubre Rajoy decide, con el apoyo del senado, aplicar el artículo 155 de la carta magna española, que le permite al gobierno central intervenir los gobiernos autónomos en casos de amenaza a la soberanía nacional. Destituye a Carles Puigdemont y a sus ministros, al tiempo que ordena la disolución del Parlament. Luego, convoca a elecciones autonómicas para el 21 de diciembre de 2017. Puigdemont se exilia en Bruselas un día más tarde, aunque es citado - junto con algunos miembros de su gobierno- por la Fiscalía y la Abogacía del Estado, quienes los acusan de rebelión, sedición y malversación de fondos públicos. Doce personasincluso Puigdemont, que no se presenta a la citación—-son procesadas y nueve son puestas en prisión provisional, entre ellos Oriol Junqueras, vicepresidente de Puigdemont. También son detenidos Carme Forcadell (presidenta del Parlament), Jordi Cuixart (presidente de Òmnium Cultural) y Jordi Sánchez (presidente de Assemblea Nacional Catalana). La violencia institucional-tanto el día del referéndum como a la hora de juzgar a los funcionarios catalanes-, la inflexibilidad y la falta de apertura al diálogo del gobierno central incrementaron la voluntad de muchos habitantes de Cataluña de separarse del estado español, lo que se confirma en los resultados de las próximas elecciones.

Como estaba planificado, el 21 de diciembre de 2017 se llevan a cabo las elecciones al Parlament. Los resultados fueron favorables a los partidos independentistas: Junts per Catalunya, vinculado a Puigdemont en el exilio, Esquerra Republicana de Catalunya y Candidatura de Unidad Popular logran 70 bancas entre los tres, mientras que los partidos no secesionistas (Ciudadanos, Partit dels Socialistes de Catalunya y Partido Popular) obtienen 57 bancas. Catalunya en Comú-Podem, que rechazaba en su plataforma tanto la declaración unilateral de independencia como la aplicación del 155 logra acceder a 8 bancas. Luego de varias maniobras políticas, el Parlament elige como nuevo presidente de la Generalitat a Quim 
Torra, candidato recomendado por Puigdemont en el exilio. De este modo, se pone fin a la aplicación del artículo 155 en Cataluña.

En febrero de 2019 comienza formalmente el juicio a los detenidos por los delitos de rebelión, desobediencia, sedición y malversación de caudales públicos, y el 14 de octubre de ese año se da a conocer su sentencia, de entre 9 y 13 años de cárcel. Esto no es bien recibido por los habitantes de Cataluña, que se manifiestan ese día en las calles. Las fuerzas de seguridad del poder central reprimen estas manifestaciones con violencia. Esto agudiza el malestar, lo que se traduce en un período de cuatro días de protestas, represión y violencia, que culmina el 18 de octubre con una huelga general y manifestaciones. El saldo es de 579 manifestantes y 288 agentes policiales heridos, y 194 detenciones. En enero de 2020, Torra declara públicamente que se adelantarán las elecciones autonómicas para ese año. Esto se ha visto imposibilitado por la pandemia del coronavirus, que ha tenido un fuerte impacto en España en general, y en Cataluña en particular. ${ }^{35}$

Estos sucesos ponen de manifiesto la problemática articulación, en el caso catalán, entre las ideas de estado y de nación. Es pertinente, entonces, considerar diversos aportes teóricos que indaguen sobre la interrelación entre estos dos conceptos. Se torna necesario, asimismo, poner en relación este concepto con otros íntimamente relacionados, como los de identidad, etnia, lengua y cultura.

La mayoría de los historiadores concuerda en que la idea de nación surge alrededor del siglo XIX. Una de las primeras definiciones es la de Ernest Renan, quien en 1882 sostiene que uno de los factores principales de consolidación nacional es el olvido, ya que detrás de cada nación hay una historia de sangre y conquista, llevada a cabo por un grupo dinástico. Desde esta perspectiva, un grupo dominante, representante de una idea unívoca de nación, sería quien,

\footnotetext{
${ }^{35}$ Debido a lo reciente de la situación, no existen trabajos críticos o historiográficos aún sobre este proceso. La información que cito proviene de diversos textos periodísticos de los periódicos El País, El Ciudadano, La Vanguardia, El Diario, Público y BBC.
} 
a través de determinadas prácticas coercitivas tendientes a "hacer olvidar" un pasado de guerra, lograra establecer un relato común de nación, que identifique a cada uno de sus miembros. Un claro ejemplo de esto en el caso catalán es la enorme represión franquista sobre la lengua y los símbolos catalanes como un intento de imponer una nacionalidad española unívoca y sin disidencias a través del olvido forzado en las generaciones siguientes de los signos de identidad nacional de los catalanes. ${ }^{36}$ El lema franquista, que sostiene que España es "una, grande y libre”, como así también el que afirma "Una patria, un estado, un caudillo", se consolidan de este modo como dispositivos discursivos tendientes a la interiorización de esta unificación que olvida y hace olvidar las diferencias identitarias. La reparación de la memoria llevada a cabo por algunos intelectuales y escritores del postfranquismo - como el propio Marsé-, como así también las campañas de recuperación de las distintas lenguas no castellanas, se consolidan entonces como dos de las estrategias fundamentales para la restauración de las identidades nacionales.

Si se logra ese olvido, agrega Renan, la comunidad logra fusionarse y consolidar un pasado común- “una herencia de glorias y pesares que compartir” (ctd en Fernández Bravo 64) - y un proyecto a futuro, un programa que incluye a todos los miembros de ese grupo nacional. El gran factor unificador es, para Renan, la voluntad de todos los individuos de pertenecer al mismo grupo. Esta mirada plantea la posibilidad de pensar una nación desde una perspectiva cívica y no étnica; es decir, lo nacional dependería de la libre voluntad del individuo y no de su procedencia racial. No consideraremos en este trabajo las perspectivas étnicas, por pertenecer-españoles, catalanes - a un grupo genético similar.

Otro aporte de relevancia para la idea de nación es el de Ernest Gellner, quien afirma en 1983 que existe una relación de identidad entre nación y cultura: "Dos personas son de la

\footnotetext{
${ }^{36}$ Nos referiremos aquí al caso catalán, aunque esta observación es pertinente para otras naciones intraespañolas, fundamentalmente, la vasca.
} 
misma nación si, y sólo si, comparten la misma cultura, entendiendo cultura como un sistema de ideas, signos, asociaciones y modos de comportamiento y comunicación" (7). ${ }^{37}$ Esta asociación, sin embargo, es necesaria aunque no suficiente: también debe existir entre los miembros de una nación la voluntad de pertenecer a una determinada comunidad nacional. Los dos criterios de Gellner ("will” y "culture") aseguran la cohesión social necesaria para la consolidación de la nación. Sin embargo, Gellner también observa que la voluntad de los miembros de participar en una nación puede lograrse por dos vías; la primera, vinculada con la voluntad de identificación; mientras que la segunda se asocia con el miedo y la coerción. El caso catalán permite observar las dos caras de este fenómeno: en primer término, como hemos visto, la persecución de lo catalán por el franquismo pretendía imponer una unidad nacional española a través de la coerción. La activa participación (a veces clandestina) del catalanismo, por otra parte, puede plantearse como una militancia que apunta a la construcción y al fortalecimiento de los lazos entre catalanes. Desde esta perspectiva, esa dirección ha operado como resistencia de una catalanidad preexistente, pero también como construcción de un sentimiento nacional en términos pragmáticos, pues se realiza mientras se practica. Los términos nacionalistas de ese ejercicio de construcción plantean, además, un límite: para configurar un nosotros, una idea de comunidad, debe construirse, asimismo, un no-nosotros, un ellos, que, en el caso catalán, se ve estimulado por la ola migratoria proveniente del sur, tema en el que ahondaremos más adelante. En esta construcción se labra necesariamente un límite, una frontera sólida que los separa.

Benedict Anderson aporta en 1983 una mirada novedosa sobre el tema. Encuentra los orígenes de la conciencia nacional en la expansión del capitalismo, concretamente en el desarrollo de la imprenta y en la búsqueda de mercancías de una incipiente industria ávida de

\footnotetext{
${ }^{37}$ Las traducciones de las citas textuales cuya referencia no se indica en español en la sección "Trabajos citados" son mías.
} 
consumidores. Una vez agotado el mercado en latín, la comercialización de la letra escrita necesitó y configuró un nuevo mercado vinculado con las publicaciones en lenguas vernáculas. Así las lenguas europeas ingresaron en el mercado de lo escrito, y más adelante, en el de la administración del estado, configurándose como lenguas de poder. Estas lenguas impresas consolidaron las bases de la conciencia nacional en tres formas distintas. En primer lugar, establecieron campos unificados de intercambio y comunicaciones, lo que contribuyó a la creación de lazos de identificación entre hablantes de la misma lengua. En segundo lugar, el capitalismo impreso dio nueva fijeza al lenguaje, que a largo plazo ayudó a forjar esa imagen de antigüedad tan fundamental para la idea subjetiva de nación. Finalmente, el capitalismo impreso creó los lenguajes de poder de una clase diferente a la de las antiguas lenguas vernáculas administrativas (73). Es claro el lazo que observa Anderson entre lengua, cultura y nación. Esta articulación de conceptos es evidente en el caso catalán.

Para Anderson, la nación se configura como un dispositivo aglutinador, que permite “imaginar" una comunidad de iguales. La nación, en este sentido "es imaginada como comunidad porque, obviando la actual desigualdad y explotación que puede prevalecer en cada una, la nación siempre se concibe como una camaradería horizontal” (9). Anderson abre el campo para plantear la posibilidad de considerar la construcción de nación como una construcción social y discursiva, producida en un determinado momento histórico y económico, con el fin de conservar y reproducir cierto orden social. La idea de la nación como construcción permite pensar no solamente los intentos represivos del franquismo por instaurar una nación española única y sin disidencias, sino también ciertos bocetos de la imagen de nación llevados a cabo por la burguesía catalana para definir las fronteras de la catalanidad. La figura del inmigrante (en nuestro caso específico, la del "charnego") queda por fuera de esas representaciones nacionalistas de los bordes de lo Propio, y contribuye a la consolidación de una imagen de nación excluyente. Es desde esta perspectiva que consideramos que la 
progresiva inclusión de esta figura en la narrativa de Marsé puede plantearse como una contraconstrucción de la comunidad imaginada sostenida por los discursos del nacionalismo catalán. Creemos que la incorporación simbólica, a través del discurso literario, de la figura del migrante a la comunidad nacional borronea las fronteras tradicionalmente inmóviles que separan lo Propio interior de lo Otro exterior. Esta fragmentación de bordes puede interpretarse como un paso hacia la construcción de una comunidad-imaginada otra, pues admite la posibilidad de imaginar comunidades reticentes al binarismo Propio-Otro, abiertas a la diversidad. Ese modo de imaginar, veremos más adelante, nos resulta compatible con ciertas miradas de la posmodernidad.

Unos años más tarde, en 1990, Eric Hobsbawm rastrea los orígenes históricos de la idea de nación y enumera los tres criterios que permitieron clasificar a un pueblo como tal. En primer lugar, afirma, debe existir una asociación histórica con un estado presente; en segundo lugar, debe darse la existencia de una antigua elite cultural poseedora de una lengua vernácula literaria y administrativa nacional y escrita. Finalmente, considera relevante una probada capacidad de conquista, fortalecedora de los lazos entre los miembros de esa comunidad nacional (Naciones 46-47). El tema de la lengua surge, entonces, como uno de los puntos primordiales revisados por el autor.

Hobsbawm también se aproxima a una definición del término "nacionalismo" y lo ubica como pensable a partir de la Revolución Francesa. Para el historiador inglés, el nacionalismo es un programa político que sostiene que los grupos que se autodefinen como naciones tienen el derecho a formar-y, por lo tanto, luchan por ese derecho- estados territoriales. Afirma: "En la práctica, el programa implica usualmente ejercer el control soberano, hasta donde sea posible, sobre una franja continua de territorio con límites claramente definidos habitados por una población homogénea que forma un cuerpo esencial de ciudadanos" ("Etnicidad” 175). Para Hobsbawm, el nacionalismo asume la nación como dada, y no cuestiona su carácter de 
construcción, y traza una línea categórica entre un "nosotros" nacional y un "ellos", es decir, aquellos que quedan por fuera de ese grupo homogéneo. El criterio que delimita ese borde suele ser etnolingüístico, pues aporta el "pedigree" necesario para demarcar las categorías. Es precisamente lo categórico de esa línea lo que Marsé socava en las novelas que revisaremos.

También Walker Connor distingue entre Estado y nación, y afirma que la superposición de estos conceptos no es obligatoria, pues el Estado es una unidad político-territorial con una cierta cantidad de habitantes, una superficie determinada y una localización geográfica específica. La nación es, por otro lado, intangible, definida a partir de un lazo psicológico que une a las personas de un determinado grupo, y a la vez las separa de los otros conjuntos de personas (92). Tanto las observaciones de Hobsbawm como las de Connor son funcionales para una mejor comprensión de los fenómenos que involucran a Cataluña. En primer término, el nacionalismo español sostiene que España no es solamente un estado, sino también una nación. Afirma asimismo que Cataluña es parte de esa nación española, en tanto forma parte del "nosotros" ibérico que diversos actores políticos—desde los Reyes Católicos hasta Francisco Franco - apuntaron a unificar, como hemos visto, a través de la tentativa de "hacer olvidar" ese pasado de conquista. Sin embargo, esta idea unificadora falla, pues asume como preexistente un "lazo psicológico", en términos de Connor, que ciertos grupos-como algunos catalanes-rechazan.

En este sentido, el catalanismo delimita una frontera entre un "nosotros" específico que se distingue del "nosotros" español, y se le opone, configurando a España como un "ellos". Barrera afirma: "La afirmación de un individuo como catalán provoca o conlleva un debilitamiento o negación respecto de España, y viceversa. Ambas identidades rivalizan y, en cierto modo, se convierten en excluyentes entre sí” (La dialéctica 348). Una facción nacionalista del catalanismo es la que pretende, de hecho, la independencia de España-y es, de hecho, la que ha guiado el proceso independentista de nuestros días. En términos de 
Hobsbawm, ese separatismo nacionalista "está basado en la 'etnicidad', lingüística o no, es decir, en asumir que 'nosotros' los vascos, catalanes, escoceses, croatas o georgianos somos gente distinta de los españoles, ingleses, serbios o rusos, y, por lo tanto, no deberíamos vivir en un mismo estado con ellos" ("Etnicidad" 174).

Por otra parte, el nacionalismo catalán también articula sus propios criterios para delimitar los bordes del "nosotros". Durante la ola migratoria proveniente del sur, como ya hemos revisado, estos discursos autorreferenciales tomaron a veces un cariz xenófobo, al punto de acuñar el término "charnego" para referirse al inmigrante no catalán, asociado desde un punto de vista lingüístico, como hemos visto, al "ellos" español. El registro de la figura del migrante dentro del grupo nacional en la novela de Marsé de 1966, Últimas tardes con Teresa, contemporánea a este proceso demográfico es, sin lugar a dudas, una reacción crítica de este tipo de discursos que proponen una perspectiva homogeneizante y unificadora para la construcción de la nación catalana, no tan alejada, en realidad, de esa "España una, grande y libre".

También resultan relevantes para aprehender el concepto de nación los aportes de Anthony Smith, quien sostiene que "una nación es una población humana que comparte un territorio histórico, mitos y recuerdos comunes, una cultura pública de masas, una economía unificada y derechos y deberes comunes para todos sus miembros" ("When" 15). En esta perspectiva, sin embargo, subyace el carácter homogeneizante de la mirada clásica, que es precisamente el que, creemos, critica Marsé. Smith también registra el carácter de constructo de la idea de nación y agrega que ésta es una pieza de imaginería social, que no tiene existencia fuera de sus representaciones ("Gastronomía" 186). La nación es, entonces, un conjunto de representaciones, construidas a partir de símbolos que se imponen como marcas identitarias a un determinado grupo o comunidad. Si los discursos sobre la nación son parte de este sistema de representaciones, resulta útil analizar de qué manera se construyen estos símbolos de lo 
Propio, cómo se vinculan entre sí y qué otros símbolos excluyen de su caracterización de lo común. Veremos que, en su proceso de configuración de una idea de nación de fronteras difusas, Marsé pone de manifiesto el carácter arbitrario de la construcción clásica de lo nacional — tanto desde la mirada española como desde la catalana — y lleva a cabo una deconstrucción de estos símbolos a través de procedimientos asociados al humor y a la parodia.

El constructo simbólico que delimita la idea de nación puede plantearse, en términos de Bronislaw Baczko, como un "imaginario social”. Baczko afirma que a lo largo de la historia las sociedades elaboran una serie de representaciones a través de las cuales se dan una identidad. Estas representaciones rodean a un poder político determinado, que reglamenta un estado-de-las-cosas particular, y configura una mirada hegemónica sobre estas (16). Así, el concepto de nación hegemónico se sostiene a partir de una serie de criterios unificadores, como la lengua o la cultura, que establece las bases de lo Mismo (lo Propio) frente a lo Otro (lo Foráneo) y traza una línea inmóvil que los separa. Lo Propio configura lo que pertenece al ámbito del "nosotros", mientras que lo Otro se corresponde con el de "ellos".

Anna Triandafyllidou amplia esta perspectiva y sostiene: "Los miembros de una comunidad tienen un número de características en común, por ejemplo, la lengua o los códigos de vestimenta, que constituyen los marcadores de su identidad. Los 'Otros' difieren de los miembros de la comunidad precisamente en estas características, hablan una lengua diferente o tienen un código de vestimenta distinto" (596). ${ }^{38}$ Más adelante, agrega que la identidad nacional puede ser concebida como una relación compleja, de doble filo, ya que por un lado se define desde sus bordes hacia adentro, y establece una serie de marcas comunes que unen a los miembros del grupo en torno a una identidad colectiva; mientras que, por el otro lado, implica una diferencia con respecto a un Otro exterior, que no pertenece a ese grupo, y del que la

\footnotetext{
${ }^{38}$ Veremos más adelante que Marsé se sirve precisamente de estos elementos (forma de vestir, habla particular) para caracterizar la transición del personaje principal de El amante bilingüe, un catalán que deviene "charnego" debido a un trastorno de personalidad.
} 
colectividad debe distinguirse. En este sentido, la conciencia nacional tiene un sentido de comunidad y de diferencia, de autoconsciencia y de conciencia de la Otredad (599). Esos Otros que delimitan lo Propio son denominados "otros significativos" (significant others). Triandafyllidou agrega que los criterios que subyacen a la categorización de cierto grupo poblacional como "otros significativos" son sumamente heterogéneos, pero que la característica que estos grupos tienen en común es que son percibidos como una amenaza para el grupo nacional, ya sea física, territorial o simbólica, en tanto ese grupo puede atentar contra la identificación que integra al grupo de lo Propio. En este sentido, puede observarse que, por un lado, la diferencia catalana dentro de España pone en jaque la idea homogénea de nación española, pero también el aluvión inmigratorio amenaza la integración-en términos hegemónicos, homogéneos — de la identidad catalana. La ola inmigratoria proveniente del sur de España en los años 60 generó un impacto demográfico rotundo, en tanto la población de Cataluña se vio aumentada en más de un millón y medio de personas en poco más de una década. En este momento histórico, entonces, este grupo se configuró como un "otro significativo", en tanto reafirmó la identidad de los catalanes en contraposición a la de los migrantes.

Los aportes de Tzvetan Todorov son relevantes en este sentido, pues ahonda aún más en la idea de la Otredad, y la vincula con dos sentidos de la palabra nación. Afirma que existe un sentido interior, que "es un espacio de legitimación y se opone, en tanto fuente de poder, al derecho real o divino: se actúa en nombre de la nación, y no de dios o del rey" (207). El sentido interno de la nación se configura así como un espacio de igualdad, que hace difusas las líneas internas del grupo - las divisiones de clase, o de género — y lo integra en una totalidad que, al menos a nivel simbólico y discursivo, se presenta como igualadora. El sentido externo de la idea de nación, por otra parte, es a partir del cual "una nación se opone a otra, y no al rey o a la aristocracia [...] los franceses son una nación, y los ingleses otra" (207). Este criterio es de 
desigualdad, en tanto se asocia con la elección de una nación sobre la otra. Para Todorov, estos dos sentidos de la idea de nación dan lugar a dos formas específicas de Otredad, que son percibidos como “enemigos de la nación”. La Otredad que se opone a la nación en sentido interior configura un enemigo interno, "los que guardan interés por agrupamientos más pequeños que la nación", mientras que la Otredad definida a partir del sentido exterior de la idea de nación integra a los que "prefieren a un país extranjero por encima de su país de origen" (242), los "enemigos externos". También Triandafyllidou distingue entre otros significativos internos ("los que pertenecen a la misma entidad política que el grupo" [600]) y externos ("los que forman una unidad política separada" [600]). La complejidad de la situación de Cataluña en relación a España y al inmigrante del sur es tal, que tanto Cataluña en relación a España como el charnego en relación a Cataluña pueden plantearse desde ambas perspectivas. Es precisamente en este punto que se comprueba que, al menos en este caso específico, el dispositivo interpretativo de lo nacional que plantea una lectura en términos "lo Propio"/“lo Otro" es inexacto, falible. Resulta imprescindible, entonces, considerar otros marcos de interpretación de lo nacional, permeables a una mirada más amplia para dar cuenta de una situación tan heterogénea. Consideramos que la literatura, en tanto lenguaje ambiguo y multisignificante, reticente a los criterios binarios de verdad o falsedad, puede aportar una perspectiva novedosa sobre este problema. Creemos, de hecho, que Marsé prefigura una alternativa funcional para plantear una comprensión más precisa de la idea de nación para el caso catalán, que rehúye de este tipo de dicotomías.

El criterio principal que delimita el ámbito de lo Propio para el caso catalán es lingüístico. Hemos visto que en este caso específico la lengua opera como una metonimia del concepto de identidad nacional, entendida ésta en términos homogeneizantes. Ahondaremos más extendidamente sobre este tema en el capítulo quinto de esta tesis, aunque, dado que un amplio sector de la historiografía catalanista registra una relación de identidad entre lengua y 
nación, resulta relevante hacer una breve mención al tema de la diglosia en Cataluña en esta sección. En 1959, Charles Ferguson acuña el término diglosia y lo define:

Una situación linguiística relativamente estable en la cual, además de los dialectos primarios de la lengua (que pueden incluir una lengua estándar o estándares regionales), hay una variedad superpuesta, muy divergente, altamente codificada (a menudo más compleja a nivel gramatical), vehículo de una considerable parte de la literatura escrita, ya sea de un período anterior o perteneciente a otra comunidad lingüística, que se aprende en su mayor parte a través de una enseñanza formal y se usa en forma oral o escrita para muchos fines formales, pero que no es empleada por ningún sector de la comunidad para la conversación ordinaria. (255)

Esta ha sido, históricamente, la situación de la lengua en Cataluña. El castellano ha sido durante muchos años la única lengua oficial de todo el estado español. De este modo, se configura como variante alta (A), es decir, como la lengua dominante, de uso público y administrativo. El catalán, por otra parte, sólo ha sido una lengua cooficial en Cataluña durante breves lapsos históricos, como hemos visto en la sección anterior de este trabajo. Debido al hecho de que durante un largo período histórico la lengua catalana ocupó un espacio doméstico, es factible considerarla la variante diglósica baja (B). Revisaremos esto en profundidad más adelante, en el capítulo quinto de este trabajo.

En 1974 — con la represión franquista ya agonizando—se consolida el Grup Catalá de Sociolingüística, que propone transformar la idea diglósica de lenguas en contacto, por la de lenguas en conflicto. Consideran que la situación de estabilidad a la que se refiere Ferguson es en realidad un proceso histórico de cambio entre una lengua dominante y una lengua dominada, que se resuelve, o bien con la aniquilación de la lengua dominada, o bien con su victoria sobre la dominante, y su consecutiva transformación en hegemónica (Hamel y Sierra 96). Esta nueva mirada permite analizar la situación entre el castellano y el catalán en Cataluña durante el franquismo, durante el cual la represión de la lengua vernácula alentó, contrariamente a lo que 
se proponía, una resistencia más encarnizada, en la que el uso del catalán se erigió como una de las formas de resistencia a la dictadura. Clandestina, la lengua catalana cobró fuerza y dotó a sus hablantes de un sentido identitario más profundo de unidad y pertenencia. Los planes de normalización lingüística, llevados a cabo por el gobierno autonómico después de la transición hacia la democracia, lograron instaurar el catalán como lengua cooficial en Cataluña, lo que permite problematizar la existencia de una situación de diglosia — o solo de bilingüismo—- en este momento en la región. Sin embargo, algunos lingüistas catalanes como Clare MarMolinero no creen que la situación de conflicto haya desaparecido por completo: "Mientras que la existencia del multilingüismo en España es ahora reconocida, la dominancia del monolingüismo es todavía implícitamente alentada" (97).

La cuestión de la lengua es, entonces, fundamental a la hora de reflexionar sobre las complejidades que atraviesan la idea de nación catalana. Los nacionalistas catalanes sostienen que la lengua es uno de los criterios homogeneizantes que unifican e identifican a quienes pertenecen a la nación catalana. De hecho, los primeros intentos de asimilación del migrante del sur fueron de tipo lingüístico. Claude Levi Strauss observa dos estrategias características a nivel antropológico frente a la diferencia del Otro cultural: la antropoémica, que propone "vomitar" al Otro, expulsarlo de la comunidad homogénea; y la antropofágica, que sugiere “devorar" al Otro, asimilarlo, destruir su diferencia (ctd por Bauman 109). Frente a estas dos alternativas homogeneizantes (la eliminación del Otro, o la aniquilación de su Otredad), cabe la propuesta de una tercera opción, más factible en los tiempos globalizantes, de incredulidad frente a las verdades inamovibles. La posmodernidad, en coherencia con sus principios intrínsecos, plantea una tercera opción frente a la pluralidad: hacer estallar los bordes que separan lo Propio de lo Otro, y en este sentido hacer entrar al Otro y a su diferencia, incorporarla dentro de una comunidad plural, diversa y vinculada. Es esta, creemos, la construcción de 
nación que se observa_ya desde Últimas tardes con Teresa, de 1966 — en la serie de novelas citadas de Juan Marsé.

Jean-François Lyotard observa que la posmodernidad se posiciona desde una perspectiva escéptica frente a los grandes relatos: el relato moderno de nación-unificador, homogéneo, binario y autolegitimado en su propio discurso-resulta sospechoso y determinante, en una sociedad que ha desarrollado una "sensibilidad ante las diferencias" y que es ahora capaz de "soportar lo inconmensurable" (5). El filósofo francés observa la pérdida de poder del estado-nación frente a las empresas multinacionales (7), lo que permite concebir la idea de un poder más plural, que acepta y se nutre de las diferencias. El lazo social, antes compacto y compartimentado, atravesado por una serie de roles duros e incuestionables, se ha transformado hoy en "un vínculo múltiple de pliegues intrincados, móviles" (15), lo que resulta en una mayor permeabilidad en las fronteras entre lo Propio y la Otredad. Lyotard afirma que, en nuestros días, el conocimiento y la información se han configurado como la principal fuerza de producción en los países desarrollados, se detiene en el tema de la circulación del conocimiento, y observa que la información y el conocimiento han perdido su valor de uso y se han convertido en un valor de cambio. Afirma que la mercantilización de ese conocimiento delimita un enorme poder económico de quienes lo producen. Para Lyotard, en un primer momento los organismos de producción de conocimiento se encuadraban dentro de los límites del estado-nación; de esta manera, gran parte de la investigación científica y tecnológica apuntaba a posicionar a cierto estado-nación en una posición de privilegio con respecto a otros países - quizá el ejemplo más rotundo sea el de las enormes inversiones en investigación científica llevada a cabo por los Estados Unidos y la Unión Soviética durante la Guerra Fría. Sin embargo, observa Lyotard, el estado-nación ya no tiene la supremacía a nivel global como espacio productor de conocimiento, ya que el poder económico es ahora de las "formas nuevas de circulación de capitales, a las que se ha dado el nombre genérico de empresas 
multinacionales. Estas formas implican que las decisiones relativas a la inversión [en qué conocimiento desarrollar] escapan, al menos en parte, al control de los estados-naciones" (7). Podemos afirmar, con Lyotard, la pérdida de vigencia de la idea de nación concebida en términos monolíticos, en tanto las lógicas económicas que rigen la superestructura cultural se abren a la multiplicidad y a las entidades plurales, y así derriban las murallas de lo homogéneo.

Gilles Lipovetsky, por su parte, observa que la posmodernidad se caracteriza por la fragmentación de la sociedad en grupos de pertenencia cada vez más reducidos. La proliferación de grupos identitarios (neofeminismo, sexualidades disidentes, minorías regionales, movimientos alternativos) proviene de la voluntad de autonomía y de la particularización. Para Lipovetsky:

La cultura posmoderna representa el polo "superestructural" de una sociedad que emerge de un tipo de organización uniforme, dirigista y que, para ello, mezcla los últimos valores modernos, realza el pasado y la tradición, revaloriza lo local y la vida simple, disuelve la preeminencia de la centralidad, disemina los criterios de lo verdadero y del arte, legitima la afirmación de la identidad personal conforme a los valores de una sociedad personalizada en la que lo importante es ser uno mismo, en la que por lo tanto cualquiera tiene derecho a la ciudadanía y al reconocimiento social, en la que ya nada debe imponerse de un modo imperativo y duradero, en la que todas las opciones, todos los niveles pueden cohabitar sin contradicción ni postergación. La cultura posmoderna es descentrada y heteróclita, materialista y psi, porno y discreta, renovadora y retro, consumista y ecologista, sofisticada y espontánea, espectacular y creativa; el futuro no tendrá que escoger una de esas tendencias sino que, por el contrario, desarrollará las lógicas duales, la correspondencia flexible de las antinomias. (4)

Desde esta perspectiva, los vínculos entre las personas estarían dados más por aquello que los une "uno a uno", que por los preceptos homogeneizantes comunitarios que sostienen la idea hegemónica de nación. Dadas estas nuevas formas de vincularse, cabría la posibilidad de plantear nuevos modos de relación, más abiertos, que prefiguran instancias colectivas de identificación: una nación atravesada por sus complejidades, sus preferencias individuales, sus 
diferencias y el respeto a la pluralidad como rasgo constitutivo del grupo. Por otro lado, Lipovetsky también da cuenta de la caída de los binarismos mutuamente excluyentes: lo Propio y lo Otro se articulan de otro modo, y registran múltiples ámbitos de intersección y de mutuas influencias. Afirma, de hecho, que se ha dado una "erosión de las formas de la alteridad" (61). Este punto de vista es permeable a una idea de nación en la que, más que una asimilación o expulsión de la Otredad, se daría una inclusión en su diferencia, derribando las murallas.

La diversidad de la Otredad, por otra parte, se pondría en tela de juicio: aquella Otredad tan rotundamente diferenciada en los relatos de nación clásicos se aproxima ahora a una sociedad cuyos vínculos son más inestables y flexibles, y sus criterios de integración se vuelven factibles de renegociación. Esta nueva forma de sociedad rechaza las estructuras uniformes y tiende a la descentralización y a la sustitución de la exclusión por la inclusión (113). De hecho, el filósofo afirma que la mirada posmoderna también se detiene, de hecho, en la organización institucional del estado, para el que se abre un camino de personalización, en el que las instituciones deben adecuarse a una sociedad móvil y abierta, que rechaza las rigideces burocráticas (136). Ya en las primeras líneas de La era del vacío, Lipovetsky afirma: "Después de la unificación nacional y la supremacía de las administraciones centrales, [surge] el reciente poder de los consejos regionales [...] el reconocimiento de los particularismos [...]; la ola de seducción democrática humaniza la nación” (12). Consideramos, con Lipovetsky, que, dado que el reconocimiento de lo particular requiere de la previa aceptación de su diversidad, la incorporación del Otro en su diferencia se torna un fenómeno coherente con nuestro contexto histórico. Más adelante, de hecho, el francés resalta el hecho de que el movimiento democrático “disuelve las referencias tradicionales del Otro" y vacía de contenido "toda diferencia esencial al implantar una identidad entre los individuos, sean cuales fueren por lo demás sus diferencias aparentes" (61). El Otro ya no es Otro, los bordes entre lo alterno y lo Propio se tornan difusos. 
El amante bilingüe de Marsé sugiere, de hecho, que ese Otro es una posibilidad más de nosotros mismos.

Esta mirada sobre la sociedad, de bordes "líquidos” (en términos de Zygmunt Bauman), mutables y borroneados, se asocia con un nuevo sistema de producción, como observa Fredric Jameson (1991). El concepto de nación moderno nace, como hemos visto, en el siglo XIX, y se incrusta en un sistema productivo capitalista clásico, vinculado a la producción en serie de mercancías dentro de un circuito de roles establecidos de producción. Este sistema económico-fijo, homogeneizante y de bordes claros entre países productores de materias primas y países industrializados — se transforma a fines del siglo XX y da lugar al capitalismo tardío, caracterizado por una economía multinacional (17), sostenida en los vínculos, las relaciones y las redes que interconectan personas a lo largo del mundo. La idea homogénea de nación es coherente con su contexto histórico, pero este ha cambiado, y deben plantearse nuevas alternativas asociadas al mundo globalizado. Agrega que el mapa político del posmodernismo debe ser global (86), lo que refuerza el hecho de que la nación, entendida en términos unívocos, no resultaría operativa para aprehender el nuevo funcionamiento social. Bauman percibe esta nueva idea de comunidad y afirma la necesidad histórica de concebir

una clase de unidad que supone que la sociedad civilizada es inherentemente pluralista, que vivir juntos dentro de esa sociedad implica negociación y conciliación de intereses "naturalmente diferentes", y que normalmente es mejor conciliar diferentes intereses que coercionarlos $\mathrm{y}$ oprimirlos perpetuamente [...]. [U]na unidad conseguida como logro conjunto de los agentes dedicados a autoidentificarse, una unidad que es una consecuencia y no una condición a priori de la vida compartida, una unidad conseguida por media de la negociación y la reconciliación y no a través de la negación, la atenuación o la eliminación de las diferencias. Creo que es la única variante de unidad (la única fórmula de reunión) que es compatible, plausible y realista dentro de las condiciones establecidas por la modernidad líquida. (188-89) 
Bauman denomina "modernidad líquida" a la posmodernidad, y la asimila a los conceptos de lo flexible, lo mutable, lo que no conserva fácilmente su forma, ni se fija (7). Opone al concepto de "modernidad líquida" el de "modernidad sólida", la etapa anterior, disciplinaria, territorial y definida. Esta categorización permite contextualizar la idea de nación clásica dentro de la modernidad sólida—cuando, de hecho, es acuñado el concepto "nación"y plantea la necesidad de redefinir ese concepto para que sea coherente con nuestro momento histórico. Afirma que la modernidad líquida requiere de la acción de los individuos para reformar y renegociar diariamente la red de lazos mutuos que constituyen una sociedad (36). Esos individuos, asimismo, son plausibles de asumir identidades diversas a lo largo de sus vidas: "Los humanos ya no nacen a su identidad [...]. La modernidad reemplaza la heteronomía del sustrato social determinante por la obligatoria y compulsiva autodeterminación" (37). Si la superestructura social ya no determina la identidad del individuo, es menos factible entonces considerar y construir una idea de nacionalidad a partir de las fronteras que oponen lo Propio a lo Otro. En una nueva forma de sociedad que se opone al "grupo" orgánico que proponía Durkheim, y al que Bauman denomina críticamente "conglomerado de yos" (71), que no es más que la suma de sus partes, los criterios de lo Propio y de lo Otro pierden operatividad. Este tipo de sociedades, entonces, primero asume al Otro en su diferencia, pero luego ya borronea las fronteras entre el nosotros y ellos: si se pierde ese todo orgánico que daba cuerpo al grupo social como lo entiende la sociología clásica, las diferencias se darían no entre grupos ("nosotros" y "ellos"), sino entre individuos, atomizando las dicotomías.

De hecho, Bauman afirma que lo que aglutina a los miembros de una determinada comunidad con una historia, costumbres, lenguaje o educación común "se deshilacha" año tras año. Agrega que, frente a esta situación, muchas comunidades intentan resucitar el nacionalismo étnico como forma de resistencia, pues la idea de etnicidad y de homogeneidad étnica ha sido uno de los factores integradores más exitosos de los siglos pasados. Sin embargo, 
observa Bauman, las comunidades no logran asimilar esta forma porque se opone a su principio intrínseco de respeto a las diferencias, y sus intentos por apropiarse de la tradición desfalleciente del estado-nación son fútiles, pues éste tuvo éxito gracias a la supresión de las comunidades autónomas, las costumbres locales y los dialectos, "promoviendo un lenguaje y una memoria histórica unificados a expensas de las tradiciones comunitarias" (184). La modernidad líquida no tolera esta intolerancia, agrega Bauman, y es por eso que, aunque es observable el surgimiento de nacionalismos, éstos suelen fallar. La posmodernidad exige, entonces, una nacionalidad pluralista y respetuosa de las diferencias. Creemos que esta mirada sobre lo nacional es coherente con el relato de nación que construye Marsé.

En esta misma línea, el aporte de Homi Bhabha agrega que la nueva idea de nación es una forma de elaboración cultural, una agencia de narraciones que se encuentra, en este momento, en un punto de renegociación de los significados de autoridad cultural y política ("Narrando" 215). La nación, apunta Bhabha, se hace en y a través de sus discursos. Por lo tanto, se torna imprescindible encontrar una nueva forma de escribir ese relato de nación, que interrogue la metáfora progresista de la cohesión social moderna ("los muchos como uno"), atravesada por la idea homogénea de una totalidad social sin fisuras ("Diseminación" 179). Considera que esta nueva escritura debe enriquecerse con las técnicas de lo híbrido, de lo transgresor a la univocidad, y propone como modelo de escritura el de la guerra de guerrillas, que opera desde las fronteras, desde los limites marginales del espacio-nación, en donde el "pueblo" no es solamente un aséptico objeto del discurso histórico, afincado en el pasado, sino un sujeto, cimarrón, mestizo, signo de un presente de negociaciones y espacios de cruce entre lo Propio ideal y lo cruzado, transgresor y contemporáneo. Se detiene en la cuestión de la Otredad dentro del ámbito de la nación, y agrega:

En lugar de la polaridad de una nación autogenerada prefigurativa "en sí misma (in-itself)" y las otras naciones extrínsecas, lo performativo introduce una 
temporalidad del "entre-medio" (in between). La frontera que marca la mismidad (selfhood) de la nación interrumpe el tiempo autogenerante de la producción nacional y altera la significación del pueblo como homogéneo. (184)

Para Bhabha, el problema no es la oposición entre la "mismidad" de la nación frente a la alteridad de las otras naciones, sino la escisión de la nación a nivel interno, que pone de manifiesto la necesidad de articular su propia heterogeneidad. Agrega que hay contranarrativas de la nación que continuamente evocan y borran sus fronteras totalizantes, que ponen de manifiesto el carácter de construcción de las representaciones de lo nacional y sus implicancias ideológicas. Bhabha afirma que estas contranarrativas hacen visibles las maniobras mediante las cuales determinados discursos definen las comunidades imaginadas en términos esencialistas. La nación se convierte, entonces, en un espacio significante liminar, atravesado internamente por los discursos minoritarios, las historias heterogéneas, las tensiones de la diferencia cultural. Esta doble escritura es denominada por Bhabha "disemiNación" (“Diseminación” 185). Consideramos que la escritura de Marsé plantea una nación coherente con esta perspectiva, y opera como una contranarrativa que borra las fronteras totalizantes, que imponen en el grupo comunitario de lo Propio una identidad esencialista. Desde su lugar de borde, Marsé representa la diferencia cultural de Cataluña dentro de la península y da cuenta de esta diferencia en castellano, socavando así las definiciones de lo nacional excluyentes, tanto estatales como catalanistas.

Mi hipótesis de trabajo se nutre de estos aportes teóricos, y considera este contexto histórico. Me propongo ahondar en las novelas mencionadas de Marsé para relevar, analizar y extraer las conclusiones pertinentes a su construcción de la idea de nación para el caso catalán. A lo largo de su producción narrativa, el novelista pone de manifiesto lo problemático y clausurador de la idea moderna de nación. Su escritura registra dos momentos: primero, un retrato o una descripción de su versión de lo que se considera tradicionalmente Propio catalán, 
y luego una deconstrucción de estos símbolos fosilizados a través de procedimientos asociados a la parodia, a la ironía y al humor. Así, evidencia los cambios y las superposiciones entre los dos términos de esta dicotomía.

Por otra parte, Marsé hace visibles en varias de sus novelas una serie de personajes, los "charnegos", asociados al aluvión inmigratorio procedente del sur español. La cuestión de la identidad nacional, entonces, es presentada desde una mirada incisiva sobre su propio carácter de construcción. Marsé pone en palabras el conflicto entre la construcción identitaria de la sociedad tradicional y la posmoderna. Encarna esta controversia en la configuración de espacios y personajes que ponen de manifiesto la posibilidad — o no-del mestizaje, y de la delimitación de una idea diversa de nación para el caso catalán. Frente a la supuesta uniformidad de una nación catalana de fronteras fijas, Marsé textualiza las formas de la Otredad y pone de manifiesto el carácter borroso y desigual de la línea que separa lo Propio catalán de lo Otro. De este modo, presenta una nueva idea de nación, heterogénea y abierta, incapaz de síntesis clausuradoras, y problematiza el tema de la lengua como criterio unificador.

Las estrategias discursivas con las que Marsé construye su idea posmoderna de nación catalana serán rastreadas a nivel textual en cada una de las novelas. En la materialidad de la escritura, el autor construye y asigna diversos significados a los ámbitos de lo catalán y de lo foráneo. A lo largo de las tres novelas, se torna visible una progresiva mixtura de significados detectables a nivel textual. Con respecto a las estrategias narrativas, aunque analizaré en todas las novelas los símbolos particulares de la construcción de lo nacional, el eje que guía mi lectura es cronológico, y se vincula con tres momentos sucesivos en la fragmentación de las fronteras que delimitan la idea de nación para el caso catalán. El debilitamiento de fronteras se asocia con una progresiva —y problemática—incorporación del Otro exterior al territorio de lo Propio.

El primero de estos momentos se observa en la tercera novela publicada de Juan Marsé, Últimas tardes con Teresa (1966). Escrita y editada en pleno aluvión inmigratorio proveniente 
del sur español, la novela se configura como el primer momento de esta evolución, en tanto registra la presencia del Otro sureño. El personaje de Manolo Reyes, inmigrante murciano, ladrón de motos y de automóviles, ambicioso y poco trabajador, configura el primer asiento del inmigrante del sur en el paisaje catalán. Esta figura todavía es en gran parte muy estereotipada. Sin embargo, no deja de ser relevante el hecho de que Marsé la integre dentro del escenario catalán, y la sitúe, de hecho, diez años antes de la fecha de publicación de la novela. Teresa, por su parte, representa lo Propio catalán, y también es en gran medida un personaje estereotipado. Sin embargo, hacia el final de la novela, Marsé logra trazar algunos rasgos que los humanizan y que los sitúan por fuera del estereotipo. Logra esto a través de la construcción de situaciones que visibilizan un tímido proceso de mutua transformación, experimentado por Manolo y por Teresa a partir de la experiencia de haberse conocido. Es el primer paso en la construcción de un discurso nacional catalán abierto, por lo que todavía las contradicciones entre lo Propio catalán y lo Otro son evidentes y pronunciadas, y las fronteras apenas comienzan a debilitarse: la ciudad da cuenta a nivel geográfico de estas compartimentaciones sociales.

La segunda novela estudiada es La oscura historia de la prima Montse, de 1970. Este texto registra un segundo momento en la progresiva incorporación del Otro sureño en su diferencia. En primer término, el narrador de esta novela, Paco Bodegas, es producto del mestizaje: su madre, Conchi Claramunt proviene de la alta burguesía catalana, mientras que su padre proviene del sur español. Paco Bodegas nació en Madrid, y es quien encarna la voz narradora. Ya desde este punto, se observa que Marsé asume la posibilidad de cruce. En esta segunda novela a revisar se prefiguran, además, numerosas instancias de intersección entre el universo migrante y el catalán, encarnadas en relaciones amoroso-sexuales entre los protagonistas. Sin embargo, si bien la posibilidad del mestizaje se asume como posible, se presenta, también, como un núcleo problemático: Paco expresa en distintos momentos del texto 
lo angustiante de su identidad cruzada y Montse decide acabar con su vida $-\mathrm{y}$ con un embarazo “mestizo". Por otra parte, en La oscura historia, la textualización de la ciudad de Barcelona también se configura como un segundo paso en la evolución de un discurso nacional catalán de bordes abiertos. Es cierto que aún la ciudad se estructura en términos dicotómicos, asignando sectores de exclusividad catalana o migrante. Sin embargo, también es innegable que Marsé delinea ciertos personajes, como analizaremos luego, que son capaces de cruzar esas categorizaciones y habitar ambos espacios. Los bordes que separan lo catalán de lo extranjero ya no son tan fuertes, y se confirma la posibilidad de la hibridez.

La tercera novela a analizar, El amante bilingüe (1990) plantea el problema de la identidad propia asociada a la identidad cultural y social de Cataluña. Ambientada en pleno contexto histórico de normalización lingüística, narra la historia de decadencia que el abandono de su mujer causa en Juan Marés, un catalán de origen humilde, criado entre migrantes, que se casa con Norma Valentí, catalana y burguesa. Norma, sociolingüista de la normalización, abandona a Marés cuando éste regresa antes del trabajo y la encuentra en la cama con un sureño. A partir de su separación, Marés entra en un proceso de degradación cada vez más rotundo que culmina con un cuadro de esquizofrenia, como indica el propio Marsé. La otra personalidad de Marés es Juan Faneca, migrante, a quien Marés inventa para recuperar a su ex mujer conociendo su debilidad por los sureños. Hacia el final de la novela, Marés/Faneca encarnan a un tercer personaje, el Torero Enmascarado, quien, revisaremos, se configura como la síntesis de ambos universos. En esta última novela a considerar, el autor pone de manifiesto, a través de la figura dual de Juan Marés/Juan Faneca, el estallido de los bordes que separan lo Propio catalán de lo Otro migrante. Lo Propio y lo Otro se mezclan en el plano individual, lo que desemboca en la psicosis. Es esa locura la que permite al Torero Enmascarado asumir una voz que vehiculiza un reclamo poderoso, en el que subyace una idea de nación inclusiva y heterogénea. 
El quinto capítulo de esta tesis es transversal a las tres novelas revisadas, y se detiene en el análisis de la tercera estrategia que despliega Marsé en su construcción de una idea de nación catalana de bordes difusos. Esta estrategia es de tipo lingüístico, y se asocia con el hecho de que Marsé es un escritor catalán de expresión castellana. Aunque el autor afirma que es esta la lengua de sus influencias_-dada la represión ejercida por el franquismo sobre la lengua catalana-, también es cierto que el castellano de Marsé lo coloca en un lugar de borde. Stewart King registra que el castellano en el que escribe Marsé es un castellano particular, cuya gramática y selecciones de vocabulario se distancian en alguna medida del castellano "castizo" de Madrid. En este sentido, la literatura en castellano de Cataluña se puede plantear, asimismo, como una manera de expresar la catalanidad (Escribir 61). La presencia de términos catalanes, como así también de una sintaxis particular, permiten pensar en un uso bastardo, mestizo, de la lengua. Esta es, argumentaré, la estrategia lingüística de Marsé, que configura en la elección y en el desarrollo de este castellano periférico una imagen de nación catalana mestiza, de cruce, abierta a las mutuas influencias entre lenguas. Se distancia, entonces, del purismo lingüísticotanto catalán como castellano- -y, como un francotirador, socava las fronteras fijas e inmóviles entre lo Propio y lo Otro, cuestionando la idea de lengua "pura". Utiliza, de este modo, un castellano catalanizado, un castellano híbrido que se encuentra en perfecta armonía con una idea heterogénea y abierta de nación catalana.

En conclusión, esta tesis propone que, a través de ciertas estrategias lingüísticas y textuales, Marsé representa en Últimas tardes, La oscura historia, y El amante bilingüe tres momentos sucesivos en la construcción de un discurso nacional catalán coherente con nuestro tiempo histórico. Consideramos, con Bhabha, que la nación se estructura en y a través de sus discursos, por lo que el discurso nacional que erige un escritor de la talla de Marsé propone una definición de nación para el caso catalán que invita a su consideración. 
Este discurso nacional catalán, legible en una serie de novelas que abarcan veinticuatro años de evolución histórica, se inserta en una lógica globalizada, de movimiento de personas y capitales, en el que ya no existen límites precisos entre quienes se integran en un grupo nacional y quienes no son parte de él. Se distancia del nacionalismo clásico y propone una idea de nación que se desarrolla en tres pasos. Primero, se registra la presencia de otro migrante, aunque aún muy diverso y no logra integrarse en el grupo de lo Propio catalán. No obstante, lo interpela con su presencia física dentro del paisaje nacional. Los bordes aún son claros, aunque existe una sutil transformación de los personajes que asumen los significados de lo catalán y lo migrante a partir de su mutua interacción. El segundo paso también configura un universo aún estructurado en compartimentos estancos y fijos, aunque se vislumbra ya la posibilidad de cruce. El narrador, mestizo, vive su descolocación con angustia, pero también da cuenta de las múltiples posibilidades de intersección. A partir de estos espacios y personajes que ostentan cierta hibridez, comienzan a socavarse las fronteras entre los compartimentos sociales y geográficos: surgen los puentes y las mezclas. Finalmente, el tercer paso en la construcción de este discurso nacional catalán en sintonía con las perspectivas de la posmodernidad informa el estallido de fronteras entre lo Propio catalán y lo Otro migrante. Es innegable que el trastorno psiquiátrico del protagonista hace evidentes las tensiones y conflictos que subyacen a este proceso, pero también es factible plantear que Marés/Faneca/el Torero encarna la intercambiabilidad de roles y personas, en una ciudad que se abre a la fusión de espacios. Los compartimentos se comprueban obsoletos y la diversidad cobra protagonismo, incontrolable.

El próximo capítulo inaugurará el análisis de ese discurso nacional que leemos en la serie de novelas seleccionadas. Nos detendremos, entonces, en el análisis de la primera etapa de la evolución a través del estudio de Últimas tardes con Teresa, de 1966. Los procesos de construcción de los personajes de Teresa y de Manolo, como así también el de la ciudad de Barcelona, darán cuenta de las estrategias discursivas que permiten detectar ciertos significados 
asociados a lo Propio catalán y a lo Otro migrante, significados que se verán modificados progresivamente en las novelas posteriores. 


\section{Capítulo 2}

\section{Últimas tardes con Teresa: el registro del Otro y su incipiente potencia transformadora}

Editada por primera vez en 1966, Últimas tardes con Teresa se configura como la novela consagratoria de Juan Marsé. En 1965, el manuscrito gana el premio "Biblioteca Breve", lo que implica no solamente su inmediata publicación por la casa editora Seix Barral sino también el posicionamiento de Marsé como escritor y novelista dentro del circuito intelectual de su época. El éxito comercial de la novela convierte a Marsé en un escritor popular, además de brindarle la soltura económica que le permite interrumpir su trabajo en el taller de joyería. Últimas tardes es la novela que convierte a Marsé en un escritor profesional.

La novela narra una equívoca historia de amor entre Manolo Reyes (conocido como “El Pijoaparte”), un joven inmigrante del sur español, ladrón de motocicletas, y Teresa Serrat, una universitaria proveniente de una familia burguesa catalana, que conspira contra el franquismo dentro del movimiento estudiantil de la Universidad de Barcelona. Mario Vargas Llosa sostiene que el equívoco sobre el que se sostiene esta historia es doble, pues "Teresa confunde al ladrón de motocicletas con un militante obrero clandestino cuyo amor, piensa, la arrancará de su clase y la salvará de sí misma, y el Pijoaparte ve en Teresa la mujer-lotería que habrá de introducirlo al mundo burgués, que él imagina aseado, rijoso, próspero y multicolor" (218). La novela no solamente relata una historia de amor (y de desamor) entre dos jóvenes, sino que enraíza en una situación de desencuentro recurrente entre dos mundos, el de la marginalidad de los circuitos inmigrantes de los suburbios y el de la hipocresía de las clases altas de Cataluña. Como indica Luis Izquierdo, la estrategia expresiva de Últimas tardes supera la historia de los deseos y las realidades de Manolo y Teresa, gracias al enlace que teje Marsé 
entre la subjetividad de los protagonistas y el contexto de intereses y barreras sociales que los determinan (168).

El malentendido sobre el que se sostiene el romance entre el Pijoaparte y la estudiante universitaria no es el único: la novela presenta, también, un equívoco en el nivel de las determinaciones sociales, por encima de la historia de los protagonistas. La otra gran confusión-y aquí puede verse la mirada crítica de Marsé sobre la sociedad de su tiempo—es la que cada uno de ellos tiene sobre la clase de la que proviene el otro. Teresa cree comprender al proletariado; lo construye a partir de determinados símbolos de la literatura marxista como un mundo comprometido, político y profundamente revolucionario. La realidad que vive Manolo es muy distinta, caracterizada por la picaresca, la supervivencia, la delincuencia y la miseria. Manolo, por otra parte, interpreta el mundo a partir de una asociación indisoluble entre dinero, origen y dignidad; quiere integrarse en la sociedad catalana pues considera que ese es un ambiente de honestidad y respetabilidad. La realidad que muestra Marsé de este mundo también es muy diferente, definida por su hipocresía, su ignorancia y su falta de solidaridad. Marsé afirma que las determinaciones sociales son tan grandes que los protagonistas de la novela no tienen ninguna posibilidad de librarse de ellas. Lo que le interesa, y lo que apuntó a retratar en Últimas tardes, es más “el chisporroteo que produce esa relación” (Belmonte 29), y de esta manera hacer visibles los prejuicios de las clases altas catalanas.

La novela consta de veintidós capítulos agrupados en tres partes, bastante desiguales en su distribución y en su ritmo narrativo (Izquierdo 169). La primera parte comprende cinco capítulos, la segunda está formada por diez y la tercera cubre siete apartados. Hay, además, dos fragmentos oníricos autónomos, incluidos en el noveno capítulo de la segunda parte, y en el tercer apartado de la tercera. Esos fragmentos suponen una "recapitulación mental” (Izquierdo 169), llevada a cabo por Maruja, la criada de Teresa y novia de Manolo, quien yace inconsciente en el hospital. Hay, también, una página inicial, anterior al primer capítulo, que 
describe una escena estática, de fuerte impronta cinematográfica. Este proemio prefigura de un modo sutil algunas de las contradicciones que se desarrollarán en la novela. Por otro lado, el libro se inicia con un epígrafe que es un fragmento del poema "Albatros", de Charles Baudelaire. Este epígrafe puede leerse como un indicador de la distancia entre las aspiraciones de Manolo y la realidad; también predice su caída (Izquierdo 171). Finalmente, el título de la obra alude a una situación que se sabe concluida (a partir del adjetivo "últimas"). Se observa entonces que todo el sistema paratextual (título, epígrafe, página inicial) deja traslucir pistas sobre los hechos relevantes de la trama, adelanta información a un lector modelo preparado para detectar esos indicios y dispuesto a sumarse al juego de lectura e interpretación. ${ }^{39}$

Cada capítulo de la novela se inicia con una cita, proveniente de fuentes sumamente diversas, desde San Mateo hasta la Información Nacional Bursátil, pasando por San Juan de la Cruz o Apollinaire. Esos fragmentos fueron “obsequiados" a Marsé por Jaime Gil de Biedma, y en la abundancia de textos provenientes del corpus de la literatura francesa se hace manifiesta esta influencia. Las citas, que funcionan a manera de epígrafe, no cumplen solamente una función ornamental, sino que también operan como puntos de partida de lectura y como claves de interpretación (Riera 194). El primer capítulo, por ejemplo, se inicia con un fragmento de "El diablo mundo", de José de Espronceda. Mediante la inclusión de estos versos en este apartado, dedicado a la presentación de Manolo, Marsé traza hilos sutiles entre el protagonista de Últimas tardes y la figura arquetípica—y trágica—del héroe romántico. Otro ejemplo se encuentra en el segundo capítulo de la tercera parte, en el que una cita de Virginia Woolf predice el desenlace de la novela, en el que la "atroz realidad" dará fin al equívoco (y al romance). ${ }^{40}$ Para Izquierdo, la funcionalidad de las citas opera desde dos frentes, convocando

\footnotetext{
${ }^{39}$ Eco afirma que el autor, a la hora de escribir su texto, tiene en mente un lector que cuenta con las competencias necesarias como para llenar esos espacios vacíos de sentido. El autor, entonces, prevé "un Lector Modelo capaz de cooperar en la actualización textual de la manera prevista por él y de moverse interpretativamente, igual que él se ha movido generativamente" (80).

40 "El destello de alguna atroz realidad saltando, como suele saltar, del mismo corazón de la primavera. Porque la juventud..." (de Un cuarto propio)
} 
al lector a incorporarse a una lectura activa. En primer lugar, contextualiza la novela dentro de la tradición occidental, y la asimila a determinados textos y lecturas previas del lector. En segundo lugar, abre el juego para que el lector pueda reconstruir los diversos vínculos que pueden tejerse entre el epígrafe y el capítulo que éstos preceden. (172).

Con respecto a las voces narradoras de Últimas tardes, se observa principalmente un narrador en tercera persona, aunque hay algunos fragmentos de monólogo interior. También hay, a veces, comentarios entre paréntesis distanciados de la voz narradora, que operan como didascalias dramáticas, especificando los modos en los que los personajes llevan a cabo diversas acciones. Asimismo, es frecuente encontrar detrás del narrador a la voz autoral, que lleva a cabo un ejercicio casi constante de crítica social a través de procedimientos distanciadores como la ironía o la parodia. Como registra Vázquez Montalbán, el autor entra y sale de la novela, incluso llega a anunciar lo que sucederá como un escritor naturalista, pero “esa intervención del autor está novelada, literaturizada y el lector contemporáneo la acepta con toda naturalidad” (“Los años épicos” 224).

La narración en tercera persona se construye a través del perspectivismo, lo que da un efecto estereoscópico a la presentación de los acontecimientos. Cuando Manolo llega a la fiesta en la que conocerá a Maruja, su entrada es registrada por diversos personajes de la novela, lo que permite al lector acceder a un registro más global, y al mismo tiempo detallado, del efecto que causa la entrada de Manolo en la reunión. Aunque la voz narradora es asumida muchas veces desde la perspectiva de Teresa, o de Maruja, la perspectiva que prima es la de Manolo. Al respecto, Manuel Vázquez Montalbán observa: “El novelista toma partido e inculca al lector el punto de vista de su personaje pretexto, el xarnego marginal que relaciona y sanciona dos códigos diferentes de supervivencia. $\mathrm{O}$, mejor dicho, en uno de los territorios se trata de un código de supervivencia; en otro, de un código para mantener la hegemonía, en nombre de Cristo o del Anticristo" ("La memoria" 143). Ya nos hemos referido en la introducción a la 
preferencia del autor por los perdedores, y a las relaciones que se plantean entre esta predilección y la recuperación de la memoria popular. El artificio del perspectivismo permite, por otra parte, la inserción en el texto de relatos que corren por cuenta de la imaginación de los personajes, y no suceden realmente en la novela, fundamentalmente, sueños de Manolo.

Para Vázquez Montalbán, la novela inaugura también la adquisición de un tono y una estrategia sintáctica que se continuará a lo largo de toda la obra de Marsé. El tono se caracteriza por su matiz sarcástico, irónico y distanciador, "encogido de hombros y con las manos en los bolsillos" (“Los años épicos” 224). La estrategia sintáctica, que Vázquez Montalbán describe como "merodeadora", es la que permite la intromisión de la voz autoral— de su juicio sarcástico-en el texto, a través de ciertos artificios que, como hemos visto, la "literaturizan". En esta estrategia Vázquez Montalbán ve la influencia de la poesía de Jaime Gil de Biedma, por su tarea como consultor literario de Marsé durante la escritura de Últimas tardes.

El lenguaje general de la novela es sencillo, sin estridencias, accesible al lector común. La descripción es frecuente y creativa, en tanto suelen hallarse adjetivos inesperados para ciertas descripciones de objetos. Se observa en ciertos fragmentos la presencia de un lenguaje lírico (el proemio es un ejemplo cabal), asociado a la descripción de situaciones en las que no es difícil registrar la influencia decisiva del código cinematográfico. Por otra parte, es frecuente el recurso de la ironía, sobre todo en lo relativo a la militancia universitaria de los jóvenes burgueses del círculo de Teresa. Vargas Llosa considera que la materia de la novela es, de hecho, la anarquía y su lenguaje es el del sarcasmo (217).

Con respecto al tiempo narrativo, es predominante la narración lineal y cronológica, aunque, como hemos visto, hay también algunas prolepsis-explícitas, además de otras sugeridas desde los epígrafes y los paratextos. También es frecuente la analepsis para referirse a la niñez de los personajes, sobre todo a la de Manolo. La historia que estructura la trama de la novela se desarrolla en un tiempo muy corto: Marsé confiesa que a la hora de escribirla era 
consciente de que si se prolongaba en el tiempo, la historia podía perder verosimilitud (Belmonte 26).

La novela se sitúa fundamentalmente en Barcelona, aunque también se observa un espacio secundario en el municipio balneario de Blanes, en la provincia catalana de Gerona. ${ }^{41}$ En Últimas tardes, Marsé prefigura una imagen particular de Barcelona. La ciudad se divide en dos espacios diversos e irreconciliables, encarnados en las figuras de Teresa y Manolo. Esta "Barcelona averiguable", como la describe Izquierdo debido a la precisión geográfica de su descripción, es también ilustrativa de una situación social en el que la burguesía restringe el acceso de las clases subalternas a los mecanismos que las rigen (171).

En primer lugar, Marsé construye una Barcelona catalana, burguesa, habitada por los estratos más poderosos de la ciudad. Esta Barcelona tiene, en la novela, su epicentro en San Gervasio de Cassolas, un barrio rico ubicado al noroeste de la ciudad. Presenta una arquitectura prolija, de casas grandes con amplios parques. La población de este espacio es catalana y catalano parlante, formada principalmente por profesionales y empresarios, representantes de las clases dominantes. A pesar de la abundancia económica, y del privilegio social, este espacio se encuentra atravesado en el texto por valores negativos como la hipocresía, la falta de solidaridad y la ignorancia. Es importante reiterar aquí que Marsé opta por representar lo catalán a través de un retrato de la burguesía, a pesar de que la diversidad socioeconómica catalana es más compleja. Como hemos mencionado en la introducción, esto ya fue registrado por Resina, quien afirma que el hecho de que Marsé no presente personajes catalanes de clase trabajadora trae como consecuencia una identificación equivocada de lo nacional en términos de clase ("The Double" 99), y que Marsé muchas veces invisibiliza—o incluso ridiculiza—a las clases trabajadoras catalanas en gran parte de sus novelas-excluye aquí Encerrados con

\footnotetext{
${ }^{41}$ Blanes es el primer pueblo de la Costa Brava, por lo que se lo conoce como el "Portal de la Costa Brava". Sus calas y playas, además de sus montañas, lo convierten en un centro turístico de relevancia a nivel catalán, español y europeo.
} 
un solo juguete (1960) y Un día volveré (1982) (Barcelona 151). La crítica de Resina nos parece atinada, pues efectivamente Marsé representa la catalanidad casi exclusivamente a partir de sus sectores más acomodados. Por otra parte, es cierto además que un sector de las clases burguesas catalanas tuvo una actitud pasiva durante los años del franquismo para proteger sus intereses financieros. Sin embargo, otro sector de este grupo fue el que tomó el rol de custodio de la catalanidad proscrita. Este rol se estructuró con una base afín al nacionalismo clásico, que construye una idea de nación excluyente y de bordes fijos. Creemos que es éste el sector que Marsé representa y socava en su obra.

En contraposición a este espacio de abundancia, Marsé delimita otro, localizado geográficamente en el barrio periférico de El Carmelo, caracterizado por casillas humildes, barro y suciedad. Este locus es habitado, principalmente, por inmigrantes del sur de España (“charnegos”), llegados a Barcelona para superar su deficiente situación económica. Esta población es castellano parlante, no suele comprender la lengua catalana, y se concentra, sobre todo, en los estratos menos favorecidos de la escala social. Es, además, el territorio de la estafa, la criminalidad, la marginalización y la pobreza.

Hemos visto que tanto Manolo como Teresa idealizan el espacio del otro, por lo que esta mirada sobre los espacios opuestos de Barcelona corre por cuenta de un narrador que, debido a la técnica del perspectivismo, muchas veces parece ubicarse fuera de las miradas de los personajes y es permeable a ser identificado con la voz autoral. Lo que esa voz narradora subraya es la solidez de bordes entre estos dos espacios, y que cualquier intento de cruzarlos está condenado al fracaso. Sin embargo, esta tesis apuntará a demostrar que la inclusión de ese Otro inmigrante, ese registro que lo ubica y lo corporiza en la sociedad catalana de su tiempo, puede considerarse un primer paso en el debilitamiento de los bordes fijos sobre los que se sustenta la idea de nación. Creemos que Últimas tardes prefigura, entonces, un primer reconocimiento del Otro-como Otro-dentro del cuerpo social, la expresión de que el Otro 
existe y habita un sector de Cataluña. Además, como veremos más adelante, creemos que, aunque sea de un modo todavía muy sutil, la experiencia amorosa vivida por Manolo y por Teresa los transforma a nivel individual, y los desplaza ligeramente de los estereotipos que asumen y representan.

Ya hemos mencionado en la primera sección de esta tesis que la escritura de Marsé se relaciona estrechamente con el circuito de la cultura de masas. Últimas tardes no es la excepción, y establece relaciones intertextuales con diversas tradiciones de la literatura occidental y española. También se observan vínculos entre la novela y el arte cinematográfico, relativas, sobre todo, a formas de narrar. Existen fragmentos - cuando Teresa conduce a toda velocidad por Barcelona, cuando Manolo entra por primera vez en la casa de Teresa, o el proemio en el que Manolo y Teresa se abrazan en una fiesta y los sorprende un viento húmedo que levanta "nubes de confeti" (5)—que parecen o bien narrados a través de una cámara de cine, o bien descripciones de fotogramas estereotípicos estáticos.

Dentro de la tradición literaria, la primera de estas relaciones es la que se observa con la novela rosa. Marsé afirma "[E]sta historia es casi una historia de novela rosa, es decir, muchacho pobre, muchacha rica... podría ser una novela de Corín Tellado si se casaran al final” (Belmonte 29). Sin embargo, Manolo y Teresa no se casan, y en esto radica la subversión al género y el distanciamiento por parte del autor de esta tradición. Como indica Izquierdo, Últimas tardes parte del esquema característico de la novela rosa, pero la desenmascara, poniendo de manifiesto su inverosimilitud (172). En este sentido, también "se burla" de los personajes, que creen que un final de novela rosa es posible. ${ }^{42}$

En segundo lugar, la novela se vincula con el folletín a nivel estructural. El final de cada capítulo parece estructurado para exigir al lector la continuación de la lectura. Shirley

\footnotetext{
${ }^{42}$ También observamos una cierta subversión a la novela rosa en el hecho de que la muchacha sea la adinerada y el joven quien no tiene recursos, pues la novela rosa tradicional replica el esquema de los cuentos de hadas y suele retratar personajes femeninos sin recursos que son "rescatados" por personajes masculinos ricos.
} 
Mangini encuentra también ciertas vinculaciones con la tradición de un tipo de folletín específico, sustentado en el bildungsroman, en tanto "la trama central es típica de la novela del folletín decimonónico, se trata de la educación sentimental de dos jóvenes: un chico pobre y guapo se enamora de una estudiante de familia rica" (21).

En tercer lugar, la novela hunde sus raíces en la tradición picaresca. El personaje de Manolo Reyes es el de un hombre de bajos recursos, que se inventa a sí mismo y apunta a mejorar su situación social de un modo rápido y eficiente. La intencionalidad crítica del texto con respecto a su sociedad, propia de la picaresca, también es patente en Últimas tardes. La novela ejerce una crítica "fulminante, irónica y moralista de la sociedad, en especial, de la burguesía, la izquierda universitaria, los intelectuales comprometidos y el proletariado" (Mangini 13). Al igual que la picaresca, la novela hace visibles la inmovilidad de clases en Cataluña y la marginalización del inmigrante pobre.

Por último, la novela se relaciona y se distancia de la corriente estética española que predomina en los años inmediatamente anteriores a su publicación: el realismo social. Si el realismo social planteaba una imagen casi hagiográfica del proletariado español, Últimas tardes viene a mostrar que "el proletario — aunque aquí sea falso — no busca más que abandonar su puesto social para ser un pequeño burgués con su cochecito, sus trajes y un empleo 'respetable"” (Mangini 16). De esta manera, la novela resulta ser una desmitificación radical de las "nobles aspiraciones de la clase trabajadora, un directo ataque a las ideas fomentadas por el realismo social" (16). De hecho, los equívocos de la novela se basan en las percepciones que los protagonistas tienen del grupo social del que proviene el otro, percepciones coherentes con la línea del realismo social. Teresa imprime en Manolo el héroe obrero que configura el eje del realismo social, y Marsé viene a decir, con sorna, que las clases marginalizadas tienen otras prioridades por encima de la revolución. 
También la forma de narrar se distancia de la del realismo social. En el aspecto formal, según Antoni Vilanova, Marsé se propone ridiculizar las pretensiones de distanciamiento y objetividad del realismo social que pretendía evitar el subjetivismo, y lleva a cabo un retorno a la interioridad de la novela psicológica. El novelista rehúye de la técnica objetivista del realismo social, que se afinca en la descripción fotográfica y en el diálogo para dar cuenta de determinadas situaciones, y apuesta por un relato en tercera persona, llevado a cabo por un narrador que se involucra con el texto (227).

Coincide con el realismo en sus intenciones críticas, aunque éstas no son reivindicativas de ningún sector político. Su visión, "ferozmente pesimista y negativa de las realidades sociales" (Vilanova 228), “agria y catastrófica de la sociedad” (Vargas Llosa 219), hace manifiesto el desequilibrio entre los sueños utópicos de una militancia de salón, ignorante de la realidad del pueblo y excluyente con respecto al inmigrante, y una realidad social marginalizada y excluida, que ni siquiera comprende la lengua en la que se habla—puertas adentro - en los sectores de poder. Marsé muestra con esta novela la impostura, la hipocresía y la falsedad que atraviesa a la burguesía catalana de su época.

De este modo, Últimas tardes se configura como una de las novelas que rompen con la tradición del realismo social para inaugurar una nueva tendencia. Como sugiere Gonzalo Sobejano:

Últimas tardes con Teresa podría definirse como la parodia—sarcástica—de la novela social en sus dos vertientes, como testimonio de los sufrimientos del pueblo y como testimonio de la decadencia de la burguesía. Amargo y pequeño Quijote de la narrativa social, este libro es en sí, al modo, como el Quixote fue el mejor libro de caballerías posible, una excelente novela social, pero ya no derecha, ya no "objetiva", sino más bien indirecta, subjetiva, expansiva, satírica, airada. (455-56) 
Ramón Buckley, Eugenio de Nora, Gonzalo Sobejano y Pablo Gil Casado coinciden en encuadrar al nuevo grupo de novelas que se distancian del realismo social a partir de los años sesenta en lo que ellos denominan "realismo dialéctico" o "realismo estructural". Últimas tardes refleja algunas de las características enumeradas por los críticos, por lo que sería permeable a ser incluida dentro de esa categoría. En primer término, este nuevo realismo se caracteriza por la reaparición del novelista en la obra, que asume, por lo general, una voz cínica y burlona. ${ }^{43}$ En este sentido, esta novela presenta "una visión dialéctica de la realidad española basada en la confrontación de diferentes estratos (ideológicos, sociales) del país" (Sobejano 412). Manolo y Teresa encarnan una serie de dicotomías (de clase, de género, de origen, de lengua, de nivel cultural, de experiencia) que permiten plantear múltiples posibilidades de dialéctica. William Sherzer sostiene que esta dialéctica es de tipo hegeliano, pues no llega a articular una síntesis integrada de los dos términos de la dicotomía.

Más adelante, los críticos afirman que el novelista dialéctico apunta a construir un diálogo con el mundo, en tanto no construye un mundo hermético y aislado, sino que sitúa la novela en una realidad próxima, al autor y al lector, por lo general urbana, y muestra las deficiencias y las endebleces de ese mundo. Esto hace que la intervención del autor en este tipo de novelas sea decisiva, pues forma parte de la propia densidad textual (Sobejano 415). El tiempo de estas novelas, añaden, suele ser la actualidad, pues apuntan a iluminar el presente (Sobejano 426). En estas generalidades también se refleja la urdiembre de Últimas tardes. Marsé, entonces, no solamente presenta las contradicciones en la Cataluña—y en la España— de su tiempo, sino que rehúye de la postura no intervencionista de la figura de autor del realismo social y juzga su realidad. Su mirada pesimista es, sin embargo, reveladora de una nueva dinámica, caracterizada por el juego entre la catalanidad y un actor social nuevo, recién llegado,

\footnotetext{
${ }^{43}$ Los autores no refieren esta causa. Sin embargo, creemos que también la reaparición de la voz crítica del novelista en el texto puede deberse a la distensión de la censura franquista, mucho más dura en los años 40 y 50 .
} 
que debe negociar su espacio en esa sociedad. La detección y puesta en palabra de la llegada del Otro sureño no es menor, sino que, creemos, es un primer paso esencial para la redefinición del concepto de lo Propio catalán. Con la historia de Teresa y Manolo, Marsé hace visibles los bordes que separan lo propio de lo foráneo y, hacia el final de la novela, a través de la sutil transformación que se da en cada personaje debido al contacto con esa Otredad, la solidez de esas fronteras comienza a debilitarse.

En la siguiente sección, analizaremos los diversos significados que se encarnan en los personajes de Manolo y Teresa y se asocian a los ámbitos de lo Otro migrante y de lo Propio catalán. Examinaremos, por ejemplo, ciertas correspondencias que se presentan como fijas entre lo Otro migrante y lo oscuro y lo arrogante, como así también un vínculo entre la Otredad y el saber empírico y desautorizado. La novela recupera a su vez una asociación tradicional entre lo Otro y la libertad sexual, opuesta a la represión característica del espacio de lo Propio. El contraste entre los términos de la dicotomía remite asimismo lo Propio catalán a los significados de la claridad y la elegancia, además de integrarlo en el ámbito del saber académico e institucionalizado. Por otra parte, nos detendremos en el tema de la lengua como marcador de la diferencia, que también localiza espacios geográficos diversos. También nos referiremos a la vinculación entre catalanidad y sentido común, al que se opone la picaresca de la Otredad migrante. Es esta picaresca la que pone en movimiento el motor de la ficción en relación con la identidad y la vuelve móvil: el Otro asumirá identidades diversas, ficticias, con el fin de sobrevivir. En tanto autorizado y auto-legitimado, lo Propio catalán no requiere de estos artilugios narrativos, y presentará una identidad fija que se sostendrá a lo largo de toda la novela.

Creemos que Últimas tardes es, entonces, el primer paso en una nueva figuración de nación catalana. Por un lado, opone significados fijos y complementarios a los espacios de lo Propio catalán y lo Otro inmigrante, y evidencia la imposibilidad de síntesis. En este sentido, 
aún no abandona el criterio de la definición clásica de nacionalidad. Por otro lado, sin embargo, es uno de los primeros registros en la literatura española de la llegada del migrante del sur a Cataluña; y no solamente da cuenta de ese arribo, sino que también le da voz y protagonismo en la novela. Además, esboza una idea sutil: durante su relación, Manolo y Teresa son, hasta cierto punto, transformados por el otro, y aunque no se informa qué sucede después de que su romance concluye, sí es imprescindible registrar que Marsé textualiza una zona gris de mutua influencia, donde las fronteras entre lo interno y lo foráneo comienzan, tímidamente, a borronearse.

La novela se inicia con un proemio al primer capítulo, donde el lector observa una escena de fuerte impronta cinematográfica en la que Teresa Serrat y Manolo Reyes se abrazan después de una fiesta:

La solitaria pareja es extraña al paisaje como su manera de vestir lo es entre sí: el joven (pantalón tejano, zapatillas de básquet, niki negro con una arrogante rosa de los vientos estampada en el pecho) rodea con el brazo la cintura de la elegante muchacha (vestido rosa de falda acampanada, finos zapatos de tacón alto, los hombros desnudos y la melena rubia y lacia) que apoya la cabeza en su hombro mientras se alejan despacio, pisando con indolencia la blanca espuma que cubre la calle en dirección a un pálido fulgor que asoma en la próxima esquina: un coche sport. (11)

Esta escena inaugural de la novela presenta inmediatamente una diferencia rotunda entre dos personajes, todavía desconocidos para el lector. Para el análisis de este prólogo, Sherzer recurre al instrumental teórico de Roland Barthes, quien delimita dos códigos en toda escritura, el proairético — que se vincula con la secuencia de acciones—y el semánticorelacionado con la explicación, a través de uno o varios semas, de cómo es un personaje, un espacio o un objeto. Sherzer explica que el código proairético define la proximidad física de los personajes y los pone en escena en una situación amorosa. Sin embargo, el código semántico opera en una dirección opuesta: “[D]entro de los paréntesis, se presenta como un 
comentario aparte del autor, se notan unas diferencias características que sugieren una separación de todo lo que el primer código une" (Juan Marsé 121). El crítico agrega que a través del primer código se observa la unión de dos personajes, mientras que a través del segundo se anuncia la separación de dos estereotipos (Juan Marsé 121).

Examinaremos ahora mediante qué estrategias discursivas Marsé construye esa distancia. A lo largo de la novela, Teresa y Manolo se irán cargando de significados: ella se asociará a lo Propio catalán, y él representará la Otredad de la inmigración del sur. Sin embargo, en la primera página estos semas permanecen aún ocultos para el lector, al que sí se le advierte de una doble diferencia. En primer término, la pareja es "solitaria" y "extraña al paisaje": la unión de los dos jóvenes es, entonces, inesperada, discordante con respecto a su contexto, por lo que es posible deducir que es infrecuente que este tipo de personajes se elijan entre sí. Esto configura una diferencia de tipo externo entre la pareja y su ámbito. Por otra parte, los miembros de esa pareja son diversos entre sí, lo que configura una diferencia a nivel interno evidente en su forma de vestir. A nivel textual, el joven se asocia con los adjetivos "arrogante" y "negro", mientras que la muchacha se vincula con "elegante", "rosa", "finos" y "rubia". Los núcleos semánticos que presenta este prólogo, definidos por los dos pares de oposiciones que configuran los términos claro/oscuro y delicado/arrogante serán constantes a lo largo de la novela, y harán manifiesta la diferencia entre lo Propio catalán y lo Otro. ${ }^{44}$ La pareja camina sobre "la blanca espuma" hacia el coche de Teresa, que no casualmente se observa como "un pálido fulgor" que confirma ser, algunas líneas más adelante, "un Floride blanco" (12). El

\footnotetext{
${ }^{44}$ María Florencia Mendizábal rastrea los orígenes de la asociación entre el color negro y la Otredad en la literatura española medieval. En las representaciones artísticas de la Edad Media, afirma, el Otro musulmán suele textualizarse vestido de negro, además de que se hace hincapié en el color oscuro de su piel. Afirma que el color negro se vincula en esa época con las fuerzas infernales, el diablo, el pecado y el mal (59). El Romancero tradicional, como las reelaboraciones del género de Federico García Lorca o Miguel Hernández también se sirven del simbolismo del color negro y le asignan significados negativos. La historia estética y cultural española, de fuerte raigambre católica, provee numerosos ejemplos en este sentido. Cabe aclarar, además, que recuperaremos esta asociación promediando este capítulo, a la hora de centrarnos en el análisis del personaje de Teresa.
} 
prólogo despliega, entonces, algunas de las ideas fundamentales sobre las que se estructurará la novela.

El texto desarrolla, entonces, una serie de diferencias que configuran dos ideas contrapuestas - lo Propio catalán y lo Otro migrante - encarnadas en los personajes y separadas todavía por fronteras bastante claras. Rastrearemos una de las formas de la estrategia discursiva a partir de la cual Marsé delinea estas ideas en el nivel de la semiosis textual en la presentación de Manolo Reyes, en el primer capítulo. ${ }^{45}$

La noche del 23 de junio de 1956, verbena de San Juan, el llamado Pijoaparte surgió de las sombras de su barrio vestido con un flamante traje de verano color canela; bajó caminando por la carretera del Carmelo hasta la plaza Sanllehy, saltó sobre la primera motocicleta que vio estacionada y que ofrecía ciertas garantías de impunidad (no para robarla, esta vez, sino simplemente para servirse de ella y abandonarla cuando ya no la necesitara) y se lanzó a toda velocidad por las calles hacia Montjuich. Su intención, esa noche, era ir al Pueblo Español, a cuya verbena acudían extranjeras, pero a mitad de camino cambió repentinamente de idea y se dirigió hacia la barriada de San Gervasio [...]. [D]ecidió abandonar la motocicleta y fumar un cigarrillo recostado en el guardabarros de un formidable coche sport parado frente a una torre. En el metal rutilante se reflejó su rostro-melancólico y adusto, de mirada grave, de piel cetrina-, sobre un firmamento de luces deslizantes, mientras la suave música de un fox acariciaba su imaginación: frente a él, en un jardín particular adornado con farolillos y guirnaldas de papel, se celebraba una verbena [...].

$[U] n$ grupo de elegantes parejas que acertó a pasar junto al joven no pudo reprimir ese ligero malestar que a veces provoca un elemento cualquier de desorden, difícil de discernir: lo que llamaba la atención en el muchacho era la belleza grave de sus facciones meridionales, y cierta inquietante inmovilidad que guardaba una extraña relación — un sospechoso desequilibrio, por mejor decir-con el maravilloso automóvil. Pero apenas pudieron captar más. Dotados de finísimo olfato, sensibles al más sutil desacuerdo material, no supieron ver en aquella hermosa frente la mórbida impasibilidad que precede a las decisiones extremas, ni en los ojos como estrellas furiosas esa vaga veladura indicadora de atormentadoras reflexiones, que podrían incluso llegar a la justificación moral del crimen. El color oliváceo de sus manos, que al encender el segundo cigarrillo temblaron imperceptiblemente, era como un estigma. Y en los negros cabellos peinados hacia atrás había algo, además del natural atractivo, que fijaba las miradas femeninas con un leve escalofrío: había un esfuerzo secreto e inútil, una esperanza mil veces frustrada pero todavía intacta: era uno de esos peinados laboriosos donde uno encuentra los elementos inconfundibles

\footnotetext{
${ }^{45}$ Debido a que realizaremos un trabajo específicamente textual, en el que rastrearemos ciertas características de la urdiembre material de la novela, nos permitiremos incluir algunas citas extensas debido a su alta productividad para este tipo de análisis.
} 
de la cotidiana lucha contra la miseria y el olvido, esa feroz coquetería de los grandes solitarios y de los ambiciosos superiores. (13-14)

Esta primera descripción de Manolo en la novela ofrece numerosas pistas para reconstruir la configuración del personaje. En primer término, Manolo, que es presentado a partir de su apodo, surge "de las sombras de su barrio", recuperando la asociación que ya revisamos entre el charnego y lo oscuro, y agregando a esta asociación un tercer término, el barrio del Carmelo. Veremos más adelante la progresiva identificación entre el muchacho y su lugar de residencia. Por otra parte, en esa imagen visual se observa una relación intertextual con el género policial, que confirma, asimismo, la vinculación del muchacho con "las sombras" del mundo criminal. ${ }^{46}$ En segundo lugar, se lo presenta como un personaje en movimiento, con una voluntad cada vez mayor de distanciarse de su barrio. Esto se pone de manifiesto en los verbos de movimiento en los que oficia de sujeto agente, los que implican una velocidad progresivamente mayor: "surgió", "bajó caminando", "saltó” y "se lanzó a toda velocidad”. E1 aspecto perfectivo de los verbos implica la concreción de la acción, lo que aporta aún más fuerza a la velocidad de ese desplazamiento. Antes de esbozar un retrato, el autor presenta al personaje a través de los verbos: las dos primeras acciones que realiza Manolo al comenzar la novela son alejarse de su barrio y robar una motocicleta. Así, ya desde las primeras líneas, se nos anuncia la disconformidad del protagonista con su medio, como así también el hecho de que es un ladrón.

En esto también se observa una diferencia entre los personajes principales de la novela. Ya hemos visto que Teresa posee “un Flóride blanco”, un auto deportivo, inaccesible a Manolo, quien roba motocicletas como medio de subsistencia. Sherzer observa que el coche de Teresa no solamente es un símbolo de su riqueza material, sino también de su movilidad frente a la

\footnotetext{
${ }^{46}$ Ya nos hemos referido al diálogo permanente entre la novelística de Marsé y la literatura de masas.
} 
inmovilidad social del Pijoaparte: "Manolo, para llegar a la altura social de Teresa, tiene que robar una motocicleta, una forma degradada del vehículo más sofisticado de su futura amiga" (Juan Marsé 121). Lo Propio catalán se define entonces a partir de significados como la propiedad y la movilidad, mientras que lo Otro es el espacio de la carencia y de la inmovilidad, pues Manolo siempre necesita de otra persona-ya sea el dueño de la motocicleta que roba o Teresa—para desplazarse.

El fragmento también delinea un primer boceto del retrato del personaje. Recupera nuevamente la asociación entre Manolo y lo oscuro ("piel cetrina") y lo califica de "adusto". Este adjetivo, ambiguo, hace pie en los dos significados asociados a Manolo en el proemio, ya que alude a lo "tostado" y a lo "poco tratable". ${ }^{47}$ Más adelante, se hace referencia al atractivo físico del joven ("belleza grave", "hermosa frente", "natural atractivo") y la consciencia del personaje de ello, esbozada en su intención de ir al Pueblo Español, concurrido por “extranjeras". El hecho de que las opciones de Manolo fueran el Pueblo Español o San Gervasio, barriada de la zona de Gracia asociada a la alta burguesía catalana, permite plantear la posibilidad de una intención de uso de esa belleza física para obtener algún tipo de beneficio económico; mientras que la opción por San Gervasio se vincula con la posibilidad de acceder gracias a su atractivo a la sociedad catalana que lo excluye. La vinculación, hacia el final de la cita, entre el esmero del peinado y "los ambiciosos superiores" refuerza esta interpretación. Se adivina, también, la ineficacia a largo plazo de este tipo de intercambio, a través de las ideas “esfuerzo secreto e inútil”, "esperanza mil veces frustrada”. No será por su belleza física, advierte el primer capítulo de Últimas tardes, que Manolo obtendrá su ansiado ascenso social. Su relación con Teresa, de hecho, se extenderá solamente durante un verano.

La cita textual también pone de manifiesto el carácter Otro de Manolo. El grupo de "elegantes parejas" de "finísimo olfato" (ya hemos revisado la asociación entre lo elegante, lo

\footnotetext{
${ }^{47}$ Según la RAE.
} 
delicado y lo Propio) percibe esa diferencia — de hecho, no solamente la percibe, sino que "no puede reprimir el malestar" de verla. La diferencia de Manolo se manifiesta a partir de sustantivos cuya morfología (en el nivel del prefijo) ostenta a nivel semántico el carácter de contrario; en este caso aluden a la ruptura de una armonía ("desorden", "desequilibrio", “desacuerdo"). Se refuerza la asociación entre el charnego y lo oscuro (“color oliváceo de sus manos", "negros cabellos"), y se le otorga a esta asociación el carácter de "estigma". Esto confirma que uno de los puntos sobre los que se basa esa Otredad se asocia al color de piel. El aspecto imperfectivo de los verbos que rodean a ese estigma ("era”, "había", "fijaba") otorga al mismo el carácter de inconclusividad, su marca de Otredad no tiene un final determinado, sino que se expresa como acción inacabada. El cuerpo de Manolo se textualiza a la vez como una posibilidad (por su atractivo) pero también como una marca (por su diferencia). Unas líneas más adelante, su diversidad física se hace expresa, también a través del aspecto imperfectivo: "Pero también había zonas tenebrosas: él no ignoraba que su físico delataba su origen andaluz - un xarnego, un murciano (murciano como denominación gremial, no geográfica: otra rareza de los catalanes), un hijo de la remota y misteriosa Murcia" (15-16). La Otredad de Manolo es perceptible a simple vista, y también su percepción de la lógica binaria que subyace detrás de estas categorías. Manolo sabe que será "murciano" para los catalanes sin importar cuál es realmente su región de origen. "Murciano", en este caso, puede plantearse como una categoría que, como la de Otro, anula la diversidad, integrándola en un término neutralizador. ${ }^{48}$ Tanto "murciano" como "xarnego" serán categorías despectivas que abarcan a quienes han llegado a Cataluña desde Andalucía, Murcia, Extremadura o cualquier otra región del sur español. En tanto Otro, Murcia se asocia con lo exótico, y es definida a partir de los adjetivos

\footnotetext{
${ }^{48}$ Puede plantearse aquí un paralelismo con el caso latinoamericano. El término "indio" aniquila simbólicamente la enorme heterogeneidad del mundo indígena, y elimina en un plano lingüístico la diversidad de aymaras, incas, aztecas, mapuches, quom, onas o aonikenk, por citar algunos; como así también la categoría de "negro" excluye en un plano simbólico la heterogeneidad formada por, entre otros, los mandingas, gangás, minas, ararás, lucumís, carabalís o congos.
} 
"remota" y "misteriosa". "Murcia" se carga entonces de una serie de significados que nada tienen que ver con los escasos 471 kilómetros que la separan de Barcelona. Murcia es, para lo Propio, el otro término de la dicotomía, y no tiene una localización geográfica específica, sino social, "gremial".

La cita textual pone de manifiesto la Otredad de Manolo a partir de su posicionamiento exterior al ámbito de lo Propio catalán, caracterizado, como hemos visto, por la claridad. Así, Manolo se apoya en un automóvil que no puede poseer, y el "metal rutilante" refleja su rostro, lo devuelve. Tampoco le está permitido el acceso al "jardín particular", iluminado por “farolillos". ${ }^{49}$ Porque es Otro, el ámbito de lo Propio catalán le está vedado, y su sola presencia en ese contexto provoca un "ligero malestar", propio de una sensación de desorden. Lo Otro migrante es entonces lo marginalizado, lo excluido.

Finalmente, cabe destacar la localización precisa de la historia en tiempo y espacio que se hace visible en las primeras páginas de la novela, de acuerdo con los preceptos del realismo decimonónico. Se le informa al lector la fecha precisa de los acontecimientos: "23 de junio de 1956”. Este año coincide con el comienzo de la oleada inmigratoria proveniente del sur de España a la que ya hemos aludido, y funciona, además, como un registro casi inmediato de ese nuevo componente poblacional en Cataluña. Diez años más tarde, cuando Últimas tardes fue publicada, este proceso se encontraba en su apogeo. Con esta especificación temporal, Marsé no solamente hace efectivo un registro del arribo del Otro, sino pone de manifiesto una cierta antigüedad en el proceso. La localización en el espacio delimitada por el recorrido en motocicleta del Pijoaparte, por otro lado, fija la zona específica de la ciudad de Barcelona en la que se desarrollará prácticamente toda la novelística del autor catalán.

\footnotetext{
${ }^{49}$ La RAE define "particular" como "propio y privativo de algo, o que le pertenece con singularidad". El ámbito de lo Propio será el de la propiedad privada, mientras que la Otredad es caracterizada a partir de la carencia o el robo.
} 
El Pijoaparte entra sin ser convidado a esa fiesta y allí conoce a Maruja, la criada de Teresa. Manolo cree que Maruja es una invitada más y se aproxima a ella. Sin embargo, hay ciertos indicios que aproximan a Maruja al ámbito de lo Otro: "Los ojos del Pijoaparte, como dos estiletes, se detuvieron en una muchacha sentada al borde de la piscina. Era morena, vestía una sencilla falda rosa y una blusa blanca [...]. [L]a envolvía un curioso aire de timidez y de abandono, como si también ella no conociera a nadie" (15). Maruja se asocia al ámbito de lo oscuro (“morena") y parece ser Otra en el grupo de invitados de la fiesta. Un poco más adelante, el Pijoaparte tiene la intención de invitarla a bailar. Revisaremos en el siguiente fragmento a través de qué estrategias discursivas Marsé retrata a este personaje:

[L]a joven morena tendió la mano al desconocido con una repentina viveza, exhibiendo de nuevo aquella misteriosa sonrisa y, en vez de dejarse conducir hacia la pista de baile, tiró del chico hacia lo más oscuro y apartado del jardín, donde dos parejas bailaban abrazándose. El Pijoaparte soñaba. Notó que la mano de la muchacha, cuyo tacto resultaba extrañamente familiar, blando y húmedo, le transmitía una frialdad indecible [...].

Iba a cumplir diecinueve años y se llamaba Maruja. No, no era andaluza, aunque lo pareciera, sino catalana [...]. "Mala suerte, hemos dado con una noia", pensó él.

- Pues no se te nota, no tienes acento catalán". (16-17)

A pesar de que Manolo no lo percibe, la cita deja traslucir el hecho de que Maruja no pertenece al ámbito de la catalanidad, sino que la une una "extraña familiaridad” con el migrante. Condensa tres significaciones con las que se describe el ámbito de lo Otro. Es, en primer término, "morena". En segundo lugar, despliega una "repentina viveza". A lo largo de la novela, el ámbito de lo catalán se prefigura como el del estudio y el profesionalismo, cuya sabiduría es de tipo institucionalizada, como veremos más adelante. La "viveza", por otra parte, afinca en el conocimiento obtenido a través de la experiencia de vida. Si el universo de lo Propio es el del conocimiento "autorizado"-la Universidad, la profesión-, el de lo Otro es el de la astucia característica de la picaresca, del conocimiento empírico adquirido fuera de los 
circuitos autorizados del saber. En tercer lugar, Maruja toma un rol activo y "tira del chico hacia lo más oscuro y apartado del jardín". Más allá de las vinculaciones posibles entre los adjetivos "oscuro" y "apartado" y el espacio de lo Otro, Maruja se prefigura como una mujer sexualizada. Geraldine Cleary observa que Marsé delimita dos espacios enfrentados en relación al ejercicio de la sexualidad en Últimas tardes: el novelista ridiculiza la actitud de las clases altas - los catalanes, en nuestro caso-, a los que asocia con una sexualidad dormida y reprimida, mientras que el universo sureño ejerce la sexualidad con mayor libertad (166). Nos referiremos a esto más adelante, pero vale mencionar la temprana referencia a esta asociación (la piel morena con la sexualización) en relación a la Otredad de Maruja. Finalmente, el fragmento pone de manifiesto la importancia de la lengua en la delimitación de los espacios de lo Propio catalán y de lo Otro: Maruja parece andaluza, pero es catalana (nos enteraremos después de que sus padres son andaluces). Sin embargo, no tiene acento catalán, por lo que queda excluida del ámbito de lo Propio. Por otro lado, el uso del término "noia", "muchacha" en catalán, concentra la doble significación de género y origen.

La lengua también es otro de los rasgos que inscriben a Manolo en el ámbito de lo Otro migrante:

Su acento era otra de las cosas que llamaba la atención; era un acento que a ratos podía pasar por sudamericano, pero que, bien mirado, no consistía más que en una simple deformación del andaluz pasado por el tamiz de un catalán de suburbio - como una dulce caída de las vocales, una abundancia de eses y una ternura en los giros muy especial-, deformación puesta al servicio de un léxico con pretensiones frívolas a la moda, un abuso de adverbios que a él le sonaban bien aunque no supiera exactamente cómo colocar, y que confundía y utilizaba de manera imprevista y caprichosa pero siempre con respeto [...] con esa fe inquebrantable y conmovedora de algunos analfabetos en las virtudes redentoras de la cultura.

El rostro de la mujer no reflejó nada. Por supuesto, se empeñó en sostener la mirada del intruso, de aquel guapo impertinente cuyas ridículas palabras revelaban su origen [...]. (20) 
La cita pone de manifiesto que Manolo es castellanohablante, lo que lo excluye en un primer nivel del ámbito de la catalanidad. Más adelante, de hecho, la madre de Teresa entabla una conversación con otros invitados a la verbena. Si bien no se especifica en qué lengua se lleva a cabo esta charla, sí se hace hincapié en el hecho de que no es comprendida por Manolo: “-En fin, criaturas-concluyó la señora, notando aún sobre ella la devota mirada del murciano, que no había comprendido ni una sola palabra de lo que allí se hablaba [...]" (21-22). El hecho de que el autor no haga expreso que esta conversación se ha llevado a cabo en catalán sino a través de la ignorancia del castellanohablante de esa lengua refuerza precisamente la situación de alteridad. Sin embargo, existe un segundo nivel de exclusión en cuanto al castellano específico de Manolo; su acento, en primer término, da cuenta de su diferencia: no importa si Manolo es sudamericano o andaluz, ya que el dispositivo de interpretación binario Propio/Otro integra en la Otredad heterogeneidades diversas y las neutraliza. El español de Manolo es calificado desde una perspectiva normativa, que insiste en la "deformación" con respecto a la norma llevada a cabo por el Pijoaparte. Así, frente a un español "correcto", el de Manolo es "abundante" en eses, "abusa" de adverbios, "imprevisto" y "caprichoso". El castellano de Manolo no solamente lo excluye del ámbito de lo Propio—ya que no habla catalán—sino que funciona como un marcador de origen, por su acento, y de nivel de educación, por su distancia con respecto a la norma.

Vargas Llosa observa que tanto Teresa como Manolo representan los espacios en los que residen, lo que evidencia la solidez de los bordes que separan lo catalán de lo foráneo: Manolo vive en el Carmelo "una barriada de Barcelona promiscua y miserable, habitada por vagos, malhechores y rameras" y ella "conspira verbalmente con sus amigos señoritos en su suntuosa casa de la playa o en los bares y cafeterías elegantes de la ciudad" (218). Revisaremos, entonces, la textualización del barrio del Carmelo: 
El Monte Carmelo es una colina desnuda y árida situada al noroeste de la ciudad [...]. La colina se levanta junto al Parque Güell, cuyas verdes frondosidades y fantasías arquitectónicas de cuento de hadas mira con escepticismo por encima del hombro [...].[S]e ven casitas de ladrillo rojo levantadas por emigrantes, balcones de hierro despintado, herrumbrosas y minúsculas galerías interiores presididas por un ficticio ambiente floral, donde hay mujeres regando plantas que crecen en desfondados cajones de madera y muchachas que tienden la colada con una pinza y una canción entre los dientes [...]. [H]ay una fuente pública en medio de un charco en el que chapotean niños con los pies descalzos: rosa púrpura de mercromina en nerviosas espinillas soleadas, en rodillas mohínas, en rostros oliváceos de narices chatas, pómulos salientes y párpados de ternura asiática. Más arriba el polvo, el viento, la aridez. (24-25)

Se observa aquí la identificación entre el Pijoaparte y su barrio; Dora Faix sostiene que Marsé suele corresponder la escenografía de sus novelas a la identidad de ciertos personajes (40). También Izquierdo registra esta identificación, y sostiene que tanto la realidad del Carmelo como la de Manolo son las de los desplazados (174). En primer lugar, a través del recurso de la personificación, el Monte cobra vida y tiene una actitud similar a la de Manolo. El monte "mira con escepticismo por arriba del hombro", con la misma arrogancia que caracteriza al muchacho. Dentro de la ciudad de Barcelona, el Monte Carmelo es el espacio de lo Otro, textualizado a partir de términos como "emigrantes", "rostros oliváceos", "narices chatas" o "pómulos salientes". Ya hemos revisado que la Otredad en este caso se manifiesta físicamente, que abarca todo lo no catalán y que muchas veces se prefigura como lo exótico: no sorprende, entonces, la referencia a Oriente. Para la descripción del barrio del Carmelo, Marsé despliega un vasto campo semántico vinculado a la aridez a través de adjetivos como "desnuda" o "árida", construcciones nominales como "ficticio ambiente floral" y sustantivos como "polvo", "viento", “aridez". Frente a la sequedad de lo Otro, el único ambiente específicamente Propio, anclado en la historia cultural y arquitectónica de Cataluña —el Parque Güell—se presenta a partir del recurso de la contraposición, con sus "verdes frondosidades". El otro núcleo semántico que se desarrolla en esta descripción es el de la ruina, prefigurado por adjetivos como "despintado", "herrumbrosas", "desfondados". La ruina da cuenta de un pasado 
mejor, que puede asociarse con la nostalgia propia de quien ha debido abandonar su lugar de origen. A pesar de su extensión, cabe incluir el siguiente fragmento para observar qué estrategias discursivas despliega Marsé para dar cuenta del carácter Otro del Carmelo:

El barrio está habitado por gentes de trato fácil, una ensalada picante de varias regiones del país, especialmente del Sur [...]. Y son los mismos pensamientos, la misma impaciencia de entonces la que invade hoy los gestos y las miradas de los jóvenes del Carmelo al contemplar la ciudad desde lo alto, y en consecuencia los mismos sueños, no nacidos aquí, sino que ya viajaron con ellos o en la entraña de sus padres emigrantes. Impaciencias y sueños que todas las madrugadas se deslizan de nuevo ladera abajo, rodando por encima de las azoteas de la ciudad que se despereza, hacia las luces y los edificios que emergen entre nieblas. Indolentes ojos negros todavía no vencidos, con los párpados entornados, recelosos, consideran con desconfianza el inmenso lecho de brumas azulinas y las luces que diariamente prometen, vistas desde arriba, una acogida vagamente nupcial, una sensación realmente física de unión con la esperanza [...]. [H]an sido vistos ciertos perros y ciertos hombres cruzando el Carmelo como náufragos en una isla, y a veces las calles se estremecen con un viento sin dirección, enloquecido, ráfagas de ira e indignación llevándose voces innobles de locutores de radio, abominables canciones, llanto de niños, papeles de periódico, rastrojos quemados, olor a hierba húmeda, a excrementos de gato, a cemento, a heno y a resina; vuelan experimentadas moscas, rueda por el suelo una caja de cartón con letras impresas en un idioma pronto familiar (Dry milkDonated by the people of the United States of America) y tropieza en los pies de un joven inmóvil, de rostro moreno y cabellos de color de ala de cuervo, que contempla la ciudad desde el borde de la carretera como si mirara una charca enfangada.

Es el Pijoaparte. (26-27)

La cita textual ostenta varias entradas de lectura. En primer lugar, delimita el ámbito del Carmelo como el del Otro, habitado por un grupo poblacional diverso al que se alude a partir de la metáfora "ensalada picante". El término "ensalada" alude a una totalidad que, si bien está formada por elementos varios, configura en sí misma una unidad, integración que se da en perjuicio del discernimiento de su diversidad. Pierde importancia, nuevamente, cuál es el lugar de origen de los vecinos del Carmelo, que provienen de "varias regiones del país, especialmente del Sur". El adjetivo "picante", por otra parte, condensa dos significados que atraviesan al espacio de lo Otro. En primer lugar, "picante" introduce una idea de inquietud, de 
acrimonia, a este grupo poblacional indiferenciado. En segundo término, aporta un cierto matiz de concupiscencia, de excitación sexual, tema al que nos referiremos más adelante.

El Carmelo es el ámbito del Otro, además, porque provee una perspectiva de la ciudad-lo Propio_-desde afuera. El monte ofrece un punto panorámico para observar a la ciudad dormida. Frente a los significados de ruina y de oscuridad asociados a este espacio, la ciudad se configura como una zona de "luces" y "edificios" que se recortan de la oscuridad, que "emergen entre nieblas". En tanto espacio de la Otredad, el barrio de Manolo se textualiza como una "isla", habitada por "náufragos". El término "náufrago" cobra aquí la doble significación de aludir a quien sobrevive — en la miseria — y a quien no es de allí, el foráneo. Mikel Aramburu sostiene que existe una distancia insalvable entre la ciudad central y los barrios de inmigrantes, lo que puede confirmarse en los testimonios específicos de dos escritores catalanes nacidos en los años sesenta dentro de familias de inmigrantes. Por un lado, Jorge Javier Vázquez, afirma: "Nuestra periferia conformaba un universo tan distinto del centro que vivíamos con la sensación de que no pertenecíamos a la ciudad" (ctd en Aramburu 142). Por otro lado, Javier Pérez Andújar considera que los barrios periféricos estaban compuestos "por gente que había venido a vivir a Barcelona y que no iba a pisar Barcelona en lustros, quizá en su vida" (Aramburu 142).

Se textualizan, además, las contradicciones que atraviesan a este grupo migrante: por un lado, existe un campo semántico vinculado a un cierto optimismo en relación con la posibilidad de ser incluidos en el ámbito de lo Propio catalán (“sueños", "todavía no vencidos", “prometen", “esperanza”). Sin embargo, a la esperanza de esa potencial "acogida nupcial” o "unión con la esperanza" se le opone un campo semántico contrapuesto, vinculado con el pesimismo y la desconfianza ("impaciencias", “con los párpados entornados”, "recelosos", “con desconfianza”). La acumulación de imágenes sensoriales desagradables de las últimas líneas resuelve este contrapunto, inclinando la balanza hacia el pesimismo y la miseria. Faix 
observa de hecho que la Barcelona de Marsé se prefigura como un ambiente "miserable, dramático y caótico del difícil período de la posguerra" (37). Recupera la afirmación de un vasto sector de la crítica, que afirma que en Últimas tardes los diferentes espacios de la ciudad definen dos mundos contrapuestos, el de "los pobres inmigrantes, los charnegos que viven en el monte del Carmelo y el Guinardó" (38) y el de un sector burgués y acomodado que reside en San Gervasio. La mirada de David García Ponce complementa estas observaciones, y considera que la nueva mirada, superadora del realismo social, dialoga con los personajes de los suburbios en lugar de fotografiarlos. Añade que la nueva técnica narrativa funde el análisis psicológico de los personajes con la interpretación crítica de sus actos, que suele oscilar entre el escepticismo y el desengaño (81).

A través de un procedimiento cinematográfico patente en la cita anterior, la cámaranarradora sube desde los pies de Manolo (doblemente textualizado a partir de lo oscuro"rostro moreno", "cabellos de color de ala de cuervo") y lo ubica en clara identificación con el paisaje. En su actitud hay también una cierta prolepsis: Manolo está “inmóvil” y “contempla la ciudad desde el borde", desde afuera. Sabemos que no podrá "moverse" de las fronteras de su barrio, ni de la exterioridad desde la que divisa el espacio de lo Propio catalán.

La madre de Teresa confirma estas observaciones páginas más adelante, y reafirma la hipótesis de que el Carmelo es, sin lugar a dudas, el espacio de la Otredad:

-Además vive en el Carmelo. Anda, hija, olvídalo. En aquel barrio nunca se sabe lo que puede pasar...

Para la señora Serrat, el Monte Carmelo era algo así como el Congo, un país remoto e infrahumano, con sus leyes propias, distintas. Otro mundo [...].

-Tú ya no te acordarás, pero cuando eras una niña, un salvaje del Carmelo estuvo a punto de matarte... (138-39)

Exótico y peligroso como el Congo, el espacio de lo Otro es percibido por lo Propio a través del dispositivo interpretativo binario civilización/barbarie. Habitado por "salvajes", es un lugar 
“infrahumano" que tiene su propia legalidad, diversa de la de la civilización. Su axiología discordante le quita previsibilidad: "[N]unca se sabe lo que puede pasar".

Frente a la Otredad de Manolo, Teresa se configura como representante del ámbito de lo Propio catalán. La primera imagen que el lector, desde la perspectiva de Manolo, tiene de la muchacha es metonímica y subraya la diferencia, y la asociación de Teresa con la claridad: “[L]a rubia, que no había reparado en él, se levantó y fue a sentarse más lejos, junto a un joven que removía el agua con la mano. Durante una fracción de segundo, por entre los dorados y lacios cabellos que cubrían parcialmente el rostro de la muchacha, el murciano pudo ver unos ojos azules que le golpearon el corazón" (16). Frente a lo moreno de Manolo y de Maruja, Teresa se presenta a partir de sus "dorados cabellos" y sus "ojos azules". Manolo se refiere a ella, además, como "la rubia", haciendo hincapié en esta característica física de la mujer. La vinculación de Teresa con lo claro no radica solamente en su aspecto físico, sino también en su vestimenta. Maruja se la muestra a Manolo "fotografiada en las páginas de la revista Hola sentada en medio de un alegre ramillete de jovencitos con smoking y muchachas vestidas de blanco" (77) o bien: "Se paró repentinamente, a unos metros de la verja, bajo un árbol, brazos cruzados y una gabardina blanquísima echada con descuido sobre los hombros” (77).

También en el uso de la lengua de Teresa se pone de manifiesto su catalanidad: “[...] mientras escuchaba aquella voz desmayada, descuidada, un poco nasal en la que el singular acento catalán se mostraba en todo momento no como incapacidad de pronunciar mejor, sino como descarada manifestación de la personalidad" (80). El acento de Manolo se vincula con una deformación de la norma, pero el de lo Propio catalán se presenta a partir de la negación de la incapacidad: no da cuenta de una carencia, sino de un rasgo enquistado en la personalidad misma de los catalanes, una singularidad..$^{50}$

\footnotetext{
${ }^{50}$ En el contexto del franquismo, esta "descarada manifestación de la personalidad" cobra ribetes políticos, pues puede leerse como una reivindicación de la diferencia cultural catalana en un marco histórico de represión de las identidades nacionales intrapeninsulares divergentes de la castellana.
} 
Teresa no solamente habla castellano con su acento particular, sino que también se comunica en catalán: "No podía oír lo que decían, pero sabía que hablaban en catalán (lo deducía por los graciosos morritos que ponía ahora Teresa, había aprendido a leer en ellos) y eso y las risas, cada vez más desatadas, bastaba para inquietarle” (225). La lengua de lo Propio se textualiza positivamente ("graciosos morritos") y funciona como otro dispositivo de exclusión de la Otredad, pues, como ya hemos referido, Manolo no la entiende.

Como hemos notado, la sabiduría de lo Otro se afinca en el conocimiento empírico, la viveza y la astucia propia de la picaresca. Frente a esto, el saber de lo Propio catalán es de tipo académico, institucionalizado. Teresa y sus amigos son estudiantes universitarios, percibidos como "raros" por Maruja: "Le contó, además, que Teresa salía a menudo con chicos estrafalarios y existencialistas - fueron las palabras que empleó la criada, casi con unción-, gente rara, estudiantes con barba, y que se pasaban la vida llamándose por teléfono, dándose citas y prestándose libros" (83).

Teresa interpreta el mundo a través de su saber enciclopédico, sin contar con la experiencia de vida necesaria para elaborar ciertos juicios. Confía en el saber autorizado para explicar la realidad, y desprecia el saber empírico propio de lo Otro, lo que es presentado por el autor con un alto nivel de ironía: "Nada las unía ahora. Maruja ni siquiera parecía darse cuenta del cambio, y sólo Teresa, con su mente más lúcida y cultivada, por comulgar diariamente con las nuevas ideas que habían penetrado en las aulas de la Universidad, lo lamentaba profundamente: la quería como a una hermana, le daba consejos, le regalaba vestidos, le decía cómo debía peinarse, vestirse y comportarse en tal o cual situación” (123). La soberbia con la que Teresa considera monolíticamente el saber institucionalizado como única fuente de conocimiento es criticada de forma mordaz por el narrador.

Esta mirada crítica sobre el saber académico puede vincularse con el antiintelectualismo del propio Marsé. De hecho, existe en Últimas tardes un uso de la ironía con 
intenciones críticas en otro plano: dos estudiantes universitarios, caracterizados con la misma sorna con la que el novelista retrata a todos los amigos de Teresa, entablan una conversación sobre "un libro de crítica literaria, de reciente aparición" que "estaba siendo devorado en la Universidad" (239). La voz narradora ridiculiza una hipótesis de este libro: "Durante un silencio general, concedido a petición de María Eulalia, la voz del lector transmitió una idea insólita, una de esas manifestaciones que a un autor le pesarán toda la vida, le perseguirán, le acosarán de noche como una pesadilla: 'En general, puede decirse que el novelista del XIX fue poco inteligente"" (239). El libro al que se alude es La hora del lector (1957), de Josep Maria Castellet, que postula la necesidad del objetivismo como técnica narrativa. ${ }^{51}$ Marsé, ferviente defensor del realismo decimonónico, rechaza estos principios, y se sirve de la novela para ridiculizarlos.

La Universidad no solamente es el ámbito en el que se sustenta el conocimiento particular de lo Propio catalán, sino que es también el espacio del complot. Nuevamente, se observan las estrategias discursivas a través de las cuales se presenta con ironía el ejercicio de la conspiración universitaria:

Impresionantes e impresionados de sí mismos, misteriosos, prestigiosos y prestigiándose avanzan lentos y graves por los pasillos de la Universidad con libros extraños bajo el brazo quién sabe qué abrumadoras órdenes sobre la conciencia, levantando a su paso invisibles oleadas de peligro, de consignas, de mensajes cifrados y entrevistas secretas, provocando admiración y duda y femeninos estremecimientos dorsales junto con fulgurantes visiones de un futuro más digno. Sus nobles frentes agobiadas por el peso de terribles responsabilidades y decisiones extremas penetran en las aulas como tanques envueltos en la humareda de sus propios disparos, derriban núcleos de resistencia, fulminan rumores y envidias, aplastan teorías y críticas adversas e imponen silencio: entonces es cuando a veces se oye, como en el final brusco de un concierto, esa voz desprevenida, pillada en plena confidencia, parece una sola, larga, tartajeante y obscena palabra:

-...y pecemeparecepecepertenece. (227-28)

\footnotetext{
${ }^{51}$ Este libro es identificado, entre otros, por William Sherzer (Juan Marsé 82).
} 
La idea de la conspiración se construye a partir de un vasto campo semántico asociado a una imaginería propia de las novelas de espías, de detectives y de aventuras, o de ciertas películas policiales, lo que subraya las filiaciones entre la novelística de Marsé y el circuito de la cultura popular. Así, términos como "misteriosos" o "mensajes cifrados" delinean un ambiente enigmático. ${ }^{52}$ El cruce de este campo con otro enraizado en la tradición épica (“impresionantes", "prestigiosos", “admiración") ${ }^{53}$ y bélica ("humareda", “derriban”, "fulminan”, “aplastan", “imponen”) configuran, en su coexistencia, un contexto atravesado por las ideas de misterio y heroísmo. La rimbombancia que genera la abundante adjetivación del fragmento, además del cruce de estos campos, ridiculiza la "sola, larga, tartajeante y obscena palabra". La alusión al Partido Comunista es velada, y a través de sus iniciales ("pecé") se vincula, desde un plano fónico permeable a una asociación semántica, a las ideas de "parecer" y “pertenecer". La apariencia—-la necesidad de aparentar — y la pertenencia—o propiedad— son dos de las características que se asignan al grupo de lo Propio catalán. De hecho, la vinculación del grupo catalán a las ideas de apariencia y propiedad serán confirmadas unas líneas más adelante por el narrador quien, ya sin ironía, expresa: "Con el tiempo, unos quedarían como farsantes y otros como víctimas, la mayoría como imbéciles o como niños, alguno como sensato, ninguno como inteligente, todos como lo que eran: señoritos de mierda" (232).

Una de las figuras características del circuito universitario es la de Luis Trías de Giralt, uno de los dirigentes del movimiento estudiantil que conoce a los Serrat desde la infancia. Su primer retrato lo vincula con la idea de lo claro: "El prestigioso estudiante llevaba todavía el

\footnotetext{
52 También "libros extraños", "quién sabe qué", "oleadas de peligro", “entrevistas secretas" o "confidencia”.

${ }^{53} \mathrm{Y}$ “estremecimientos", "fulgurantes", "nobles frentes" o "decisiones extremas".
} 
rostro y los cabellos mojados [...]. Vestía un amplio jersey blanco y pantalones claros de hilo" (103). Más adelante, la pluma mordaz de Marsé delinea con mayor detalle el retrato del joven:

Estudiante aventajado de Económicas, nieto de piratas mediterráneos, hijo de un listísimo comerciante que hizo millones durante la exportación de trapos durante los primeros años cincuenta, era alto, guapo, pero de facciones flácidas, deshonestas, fundamentalmente políticas, carnes rosadas, el pelo rizoso y débil, la mirada luminosa pero infirme: parecía un Capeto idiotizado y con paperas [...]. [T]enía ese aire perplejo de manso seminarista en vacaciones, con un leve balanceo de la cabeza a causa del vértigo teológico, del peso trascendental de las ideas o de una simple flojera de cuello, como si andara graciosamente desnucado. ${ }^{54}(104-05)$

La estrategia discursiva de Marsé delinea al retrato de Luis en dos partes. La primera parte, prefigurada a través de la enumeración de una serie de adjetivos positivos, culmina con la conjunción adversativa "pero"; luego de la cual se inicia la segunda parte, en la que se lo ridiculiza. Esta sección, más extensa, lo refiere en términos metonímicos y asigna a diversas características físicas adjetivos relacionados con la idea de debilidad. La idea de falta de fuerza sugerida por la enumeración metonímica es rematada hacia el final, a través de una serie increscendo de comparaciones en las que se recupera-con sentido irónico-la técnica de contraponer ideas positivas y negativas con el fin de ridiculizar. Es recurrente, además, la vinculación sutil entre Luis y lo religioso ("seminarista", "vértigo teológico"). Si bien en Últimas tardes, la asociación entre lo Propio catalán y lo católico no es tan intensa como lo será en la próxima novela a analizar, ya comienza a delinearse.

Luis encarna también la represión sexual asociada a su grupo: "Ciertos elementos de derechas están empeñados en decir que la hermosa rubia politizada se acuesta con sus amigos, por lo menos con Luis Trías de Giralt. Pero todo el mundo sabe que, aunque son tiempos de

\footnotetext{
54 "Andara" es textual. Nos referiremos a esta anulación de la irregularidad del verbo en el capítulo 5 de este trabajo.
} 
tanteo por arriba y por abajo, de eso todavía nada" (228). De hecho, hacia el comienzo de la novela, Teresa decide perder su virginidad con Luis, sin resultados:

[S]ólo sabía que había sido como si alguien vomitase o muriese abrazado a ella. Apenas tuvo tiempo de desabrocharse la blusa. Tampoco había tenido tiempo de sentir su peso: tendido de lado, cogidito a sus hombros como un pájaro y con el rostro húmedo escondido en su cuello igual que si temiera un castigo del cielo, se estremeció de pronto y sus manos se crisparon horriblemente en los brazos de ella ("iQué fa aquest ximple, peró qué fa aquest ximple!") y se hizo pequeñito, y soltó un leve chillido de conejo, y se fue como un palomo. (119)

La precocidad de Luis da cuenta de su falta de virilidad. Nuevamente, cabe aquí rastrear la estrategia discursiva a partir de la cual Marsé asocia al espacio de lo Propio catalán la represión sexual. El encuentro erótico se describe a través de una doble negación vinculada a Teresa: la del agrado, con la figura retórica de la comparación con la muerte y el vómito; y la de la experiencia en sí, a partir de las construcciones adverbiales "apenas tuvo tiempo" y “tampoco había tenido tiempo". La cita corrobora un proceso de empequeñecimiento cada vez mayor, en el que a través de la inclusión de diminutivos y de la comparación con animales cada vez más inofensivos se minimiza al personaje de Luis. Su precocidad también se construye en el sistema verbal, dado en un primer momento por una abundancia de cláusulas de participios (lo que otorga al sujeto un matiz de pasividad, ya que no existen verbos conjugados), al que le sigue una enumeración polisintética de verbos en pretérito perfecto simple. El recurso de la polisíndeton contribuye a crear un matiz de prisa, mientras que el aspecto perfectivo de los verbos acumulados otorga a la cita el carácter de acción terminada. La referencia al catolicismo retorna a través de los miedos sobre los que se sustenta esa represión: "igual que si temiera un castigo del cielo”. La frase en catalán (“iQué hace este tonto, pero qué hace este tonto!”) confirma la adhesión lingüística de Luis al espacio de lo Propio. 
Frente a la represión sexual que caracteriza al espacio de lo catalán, el espacio de lo Otro es textualizado a partir del ejercicio de una sexualidad libre: "Era curioso lo que ahora estaba pensando: allí mismo, en la planta baja, en aquel pequeño y sórdido cuarto de criada, dos seres, dos hijos sanos del pueblo sano, acababan de ser felices una vez más, se habían amado directamente, y sin atormentarse con preliminares ni bizantinismos, sin 'arrièrepensée' ni puñetas de ninguna clase" (120). Filtrado por el dispositivo interpretativo engagé de Teresa, al que nos referiremos con más detalle más adelante, que imprime en los personajes de Maruja y Manolo los de "hijos del pueblo", Teresa advierte las diferencias entre los dos universos. A las reservas propias de la represión burguesa de lo Propio ("preliminares", "bizantinismos", “arrièrrepenseé", "puñetas"), se opone un espacio más libre y directo de ejercicio de la sexualidad ("hijos sanos del pueblo sano", "felices", "directamente"). Sherzer apunta que en Últimas tardes, no sólo Manolo y Maruja, sino toda la clase obrera representan la liberación sexual que no reprime ni se autorreprime (Juan Marsé 153).

La oposición en el plano de la represión sexual es encarnada, sobre todo, a partir de los juicios contrapuestos que Teresa tiene de Luis y de Manolo.

Vestía un amplio jersey blanco como de toalla y pantalones claros de hilo [...]. Tendió el oído al zumbido de la motocicleta que se apagaba a lo lejos y añadió¿Oyes? Nuestro amigo el xarnego ha vuelto a hacer de las suyas...

Teresa seguía dándole la espalda. Es más hombre que tú, pensó. Instintivamente apretó los muslos [...]. Sí, quién iba a decirlo: tras aquella fachada de líder universitario, de ardiente visionario de futuro, no había más que una blanda, asquerosamente blanda e inexperta virilidad. Aquellas manos de arrebatado orador habían albergado con temblores de mala conciencia burguesa, quién iba a decirlo, sus pechos de fresa". (103)

Nuevamente, la vestimenta de Luis lo asocia al ámbito de lo claro. Teresa registra, además, las contradicciones entre apariencia y realidad que se concentran en el personaje de Luis: en primer lugar, su aparente virilidad, pero también su aparente progresismo. El muchacho no solamente 
elige el término despectivo "xarnego" para aludir al Pijoaparte, sino que también manifiesta una crítica velada al ejercicio de su sexualidad. Manolo, por otra parte, "es más hombre” que Luis, a los ojos de Teresa. Beverley Skeggs examina las relaciones entre clase y sexualidad, y registra que las clases obreras suelen ser representadas, a nivel sexual, a través del exceso; mientras que las clases altas suelen definirse a través de ideas como la represión y el refreno (99). También Frantz Fanon se refiere a la representación hipersexuada del sujeto de color por la hegemonía blanca, y afirma: “[P]ara la mayoría de los blancos, el Negro representa el instinto sexual (no educado). El Negro encarna la potencia genital por encima de las morales y de las prohibiciones" (154).

Sin embargo, una vez que comienza el proceso de desmitificación del universo popular - y Teresa adquiere cierta experiencia de vida, y comienza a interpretar la realidad más allá de sus libros_-la sexualidad que caracteriza al ámbito de lo Otro se vuelve perturbadora. Teresa asiste a una fiesta popular en el Salón Ritmo, en la que "casi todos eran andaluces" (250). Una vez allí, pierde de vista a Manolo y lo busca entre la gente, cada vez más asustada:

Una mano atrevida tiró de sus delicados cabellos de oro, y labios pegados groseramente a su tierna oreja babeaban palabras obscenas. "¿Me buscas a mí, rubia?", "Niñapijo, qué buena estás". "No corras tanto, princesa, que pierdes las bragas" [...]. De pronto algo se movió detrás de las cajas: una muchacha morena, de grandes y soñadores ojos negros, con trenzas, retrocedía hacia el rincón mientras se arreglaba la falda. Miraba a Teresa sonriendo algo azorada, pero sin un pestañeo, sin remilgos [...]. Junto a ella se incorporó un mocetón pelirrojo con chaqueta de camarero y una botella de cognac en la mano [...]. ([M]iró por última vez a la insólita pareja que se revolcaba a sus pies, en medio de un glorioso olor a humedad), balbuceó una disculpa, y luego dio media vuelta y salió corriendo. (254-55)

Nuevamente, registramos la asociación entre lo oscuro y lo Otro (“morena”, “ojos negros"). Aquel ejercicio de la sexualidad idealizado antes por Teresa es ahora textualizado desde una perspectiva bacanal, que disloca su lugar de autoridad: Teresa "balbucea" y "sale 
corriendo". El Otro ya no es un hijo sano del pueblo, sino que se lo deshumaniza a partir de la textualización metonímica ("una mano", unos "labios") que no consolidan un ser humano completo. Se subraya asimismo la desinhibición; en este momento prefigurada como una carencia y no como un acto de libertad frente a la represión sexual que caracteriza a su clase. ${ }^{55}$ En el espacio de lo Otro rige otra legalidad, y Teresa no cuenta con los recursos-ni con la experiencia-para moverse con soltura. Su apariencia no colabora con el hecho de pasar desapercibida: ${ }^{56}$ "El azar quiso este día adornarla con una sencillez casi dominguera (falda blanca y plisada, blusa azul de cuello alto y ancho cinturón negro) que habría hecho juego con el ambiente de no ser por su lánguida melena de niña bien y su piel tostada por el sol del ocio" (250). La distancia entre lo Propio catalán y lo Otro es, por ahora, rotunda, e imposible de síntesis.

El susto de Teresa también puede vincularse con una ruptura de lo que Mike Featherstone denomina "calculating hedonism" y David Brooks llama "utilitarian pleasure" (ctd en Skeggs 104). Estas categorías se refieren a la apropiación por parte de los sectores dominantes de un cierto ejercicio "excesivo" de la sexualidad de los sectores subalternos. Skeggs afirma que ciertos sectores progresistas de las clases altas se apropian de la idea de "sexualidad excesiva" que asignan a las clases obreras, aunque le imponen nuevos límites dentro de los estándares de su clase. Así, “el exceso contenido es aceptable dentro de ciertos límites, si es practicado por aquellos que son vistos como capaces de autogobierno y refreno" (104). El ejercicio de la sexualidad de Teresa puede encuadrarse dentro de esta perspectiva; la muchacha de hecho insiste en la importancia de librarse de su "maldita virginidad" (124). Sin embargo, el cuadro al que asiste en la fiesta popular excede los límites de su "calculating hedonism".

\footnotetext{
${ }^{55}$ En, por ejemplo, "sin un pestañeo, sin remilgos".

${ }^{56}$ Evidente en "delicados cabellos de oro", "rubia", "niñapijo", "princesa".
} 
Finalmente, la muchacha encuentra a Manolo y se van de la fiesta. Teresa vuelve a sentirse segura en su espacio: "Terminaron la fiesta en el Cristal City Bar, entre respetables y discretas parejas de novios que a las nueve de la noche deben estar en casa, terminaron besándose en paz en el altillo inaccesible a murcianos desatados y a tocones furtivos, frente a dos gin-tonic con su correspondiente y aséptica rodajita de limón” (255). Una vez superado el susto de la fiesta de la "barbarie", Teresa se recupera en el ámbito de la "civilización".

En este punto, cabe recuperar las observaciones de Nancy Fischer, quien argumenta que los actos sexuales no tienen un significado en sí mismos, sino que son definidos por la cultura (51). En esta línea, observa que, en nuestro sistema cultural, el discurso de lo sexual se encuentra estrechamente enlazado con un discurso axiológico sobre lo moral. Fischer observa que esa moralidad se sustenta en afirmar una superioridad moral para un sector, frente a la estigmatización, por la vía moral, de otros (53). Así, la cita que se refiere al sobresalto de Teresa en la fiesta de los andaluces prefigura dos campos semánticos opuestos, que delimitan dos espacios morales enfrentados a través de los adjetivos calificativos: la mano atrevida tira de sus delicados cabellos, los labios groseros se pegan a su delicada oreja. Al espacio de lo “obsceno" (que la RAE define como “ofensivo al pudor") se opone, en la segunda cita, el de lo "respetable" y "discreto".

El discurso de la moralidad no solamente autoriza (y desautoriza) determinadas prácticas, sino que también, según Fischer, marca ciertos límites simbólicos: las personas de una comunidad intentarán sostener que alguien "no pertenece" porque sus comportamientos supuestamente no concuerdan con los estándares morales de la comunidad, por lo que los límites morales marcan límites de grupo (55). El criterio de "lo moral”, que es establecido por los sectores dominantes, define una cierta jerarquía y un criterio de exclusión: "[L]as acusaciones de inmoralidad suelen reflejar las tensiones sociales entre las clases altas y las obreras, los autóctonos y los extranjeros y las diferencias de tipo racial” (55). La ridiculización 
de la represión sexual burguesa, por parte de Marsé, no deja de ser significativa, y subversiva de las representaciones estancas que hemos revisado. El novelista, a través de la descripción de dos ámbitos de ejercicio de la sexualidad, altera las cargas positiva y negativa asignadas por la hegemonía a la sexualidad de lo Propio catalán y de lo Otro. No obstante, lleva esto hasta cierto punto, y a veces hace visible la construcción hegemónica del comportamiento sexual de la Otredad. La escena de la discoteca asocia el espacio de lo Otro a una sexualidad desbordada a través de una descripción esperpéntica, sin embargo, la reacción de Teresa no deja de ser risible.

Frente a lo "desatado" de la Otredad, lo Propio catalán se configura como el espacio de la obediencia y el sentido común. La cultura popular catalana asume que una de las características propias de lo catalán es la del seny (traducido al español como "cordura", “sentido común"). ${ }^{57}$ La familia de Teresa encarna este sentido práctico. El padre, Oriol, tiene una respuesta práctica a la internación de Maruja. ${ }^{58}$ Rechaza que su esposa y su hija pretendan quedarse al lado de la enferma; opina que Teresa es "otra que hace tonterías" porque decide permanecer en el hospital. Oriol le dice: "Deberías irte a casa y acostarte" (134). El padre de Teresa ha puesto a disposición de Maruja los recursos prácticos que se necesitan para que mejore, y no contempla la necesidad emocional de su esposa y de su hija. La esposa, por otra parte, obedece y adscribe a los imperativos del seny.

Marta Serrat también encarna las características de lo catalán. En primer lugar, se vincula con lo claro y lo delicado: "Tenía también un delicado rostro ovalado, [...] [con el] fino mentón y las pecas y los ojos de agua, amén de los cabellos pajizos y juveniles” (136). En segundo lugar, Marta Serrat representa físicamente el seny:

\footnotetext{
${ }^{57}$ Al seny catalan se le opone la rauxa. La filosofía romántica caracteriza la manera de ser catalana a partir de dos principios contradictorios, "el seny, o sentido común, y rauxa, o arrebato". La rauxa se asocia a los episodios revolucionarios de la historia catalana, como la Guerra de los Segadores, o el 1714, mientras que el seny sería una característica propia de la catalanidad (Boadas 44).

${ }^{58}$ Nombre tradicional catalán, que deriva del latín "aureus", dorado. El nombre refuerza la asociación entre lo Propio y lo claro, lo luminoso, además de confirmar un vínculo con la idea de riqueza material.
} 
[S]u mujer poseía una pierna realmente catalana, recia, familiar, confortable, tranquilizadora, una pierna que atestiguaba la salud mental y la inquebrantable adhesión de su dueña, por encima de posibles pequeños devaneos, a las comodidades del hogar y a la obediencia al marido, una pierna, en fin, llena de sumisión y hasta de complicidad financiera, símbolo de un robusto sentido práctico y de una sólida virtud montserratina. Y dijo la pierna: "Como tú quieras, Oriol”. (136)

A través de la condensación de significados vinculados con el sentido común catalán utilizados irónicamente para referirse a la pierna, el narrador configura el universo conservador de lo Propio. El remate de ironía se da a través del recurso de la personificación, a través del cual la pierna_-símbolo y síntesis de la catalanidad—“dice” su obediencia.

El hecho de que un personaje femenino se textualice a partir de lo corporal (y ni siquiera como una totalidad, sino a través de la metonimia), al tiempo que afirma su sumisión al marido, puede examinarse desde una perspectiva de género. Así, Simone de Beauvoir afirma que en la antinomia tradicional alma/cuerpo, el alma-valorada positivamente-tradicionalmente se asocia a lo masculino y a lo trascendente; mientras que lo femenino se vincula con el cuerpo y lo inmanente, juzgado negativamente (ctd en Conboy et al. 2). De Beauvoir subraya que mientras que procesos como el embarazo y el parto han contribuido a cercar a la mujer en una representación fijada a su biología, el hombre es libre de estas limitaciones sólo porque "ignora magníficamente el hecho de que su anatomía también incluye glándulas, como los testículos, y que también segregan hormonas. Piensa en su cuerpo como en conexión directa y normal con la naturaleza, a la que cree aprehender objetivamente" (ctd en Conboy et al. 2). Para Elizabeth Spelman, que también distingue esta asociación (110), esto contribuye y ha contribuido a lo largo de la historia a la degradación y a la opresión de la mujer (125).

El ámbito de lo catalán es, hemos visto, el de la legalidad. Este espacio genera identidades simples, auto legitimadas ontológicamente en tanto Propias. Débora Betrisey 
registra que la identidad es un proceso bidimensional, que implica una dimensión individual y subjetiva y otra colectiva o social. Como hecho social, afirma, la identidad se pone en juego con un grupo de sujetos (lo Propio) que comparten una serie de significados comunes. Esta comunidad legitima y afirma esa identidad (152). La identidad de Teresa, entonces, ha sido confirmada dentro de su clase y de su catalanidad, y por, lo tanto, no requiere de confirmación ni de exploración: Teresa no tiene, de hecho, apodos. El espacio de lo Otro, por otro lado, suscribe a una legalidad diversa. Manolo busca ser aceptado en el espacio de lo Propio catalán, $\mathrm{y}$, por lo tanto, intenta legitimarse dentro de sus preceptos. Al no contar con una legalidad per se, Manolo construye otras identidades para ser aceptado. ${ }^{59}$ La identidad, estanca en el caso de lo Propio, es móvil para la Otredad.

Manolo Reyes asume, en primer término, un alias, el del Pijoaparte. Este apodo merece especial atención, pues concentra dos significados asociados al espacio de lo Otro. De hecho, al presentar al personaje, Marsé escribe: "Hay apodos que ilustran no solamente una manera de vivir, sino también la naturaleza social del mundo en que uno vive" (13). El término "Pijoaparte" puede leerse como la conjunción de dos semas: "pijo" y "aparte". Una de las acepciones del primer término por la RAE es "miembro viril", lo que permite a Cleary afirmar que, en el caso de Manolo, tiene un sentido literal y figurativo; pues, por un lado, el muchacho se sirve de su sexualidad para obtener beneficios económicos, mientras que por el otro "avanza" en el mundo ejerciendo su sexualidad. Nichols afirma, asimismo, que el término "aparte" opera como un superlativo (165). Cabe, por otra parte, plantear otra línea de interpretación, a partir de otra de las acepciones de la palabra. Según la RAE, "pijo" es también aquello propio de la clase social adinerada. Desde esta perspectiva, el término "aparte" puede pensarse como una

\footnotetext{
${ }^{59}$ Se observa aquí la serie posible entre Manolo Reyes y el Julian Sorel de Stendhal o el Eugène de Rastignac de Honoré de Balzac, entre otros "jóvenes de provincias" que intentan reinventarse para lograr cierto ascenso social. Esta filiación ya ha sido afirmada por el mismo Marsé: "En efecto, el Pijoaparte es el hijo natural de Julian Sorel y de Gay Gatsby. Y, al igual que ellos, es también hijo de sí mismo, porque niega su origen y lo reinventa" (ctd en Turpin 48).
} 
distancia, el Pijoaparte será entonces quien está "aparte" de las clases privilegiadas. De este modo, el alias con el cual el protagonista de Últimas Tardes entra y sale de la novela condensa dos significados asociados a lo Otro; uno asociado a la sexualidad y la virilidad, y otro a la exclusión social.

En segundo lugar, el muchacho también se construye otra identidad, asociada con su ascendencia. Manolo encuentra los instrumentos para fabricar un relato sobre su origen en el hecho de que su madre, viuda en el momento de su concepción, trabajara fregando pisos en el palacio del Marqués de Salvatierra. El muchacho fragua y difunde sutilmente una historia sobre su condición de hijo ilegítimo del marqués, y crea otro alias, anterior al Pijoaparte, el del Marqués (65). Cuando, por otro lado, se presenta en la verbena de San Juan en la que conoce a Maruja, se presenta como "Ricardo de Salvarrosa" (20), y le dice a Maruja que los amigos lo "llaman Richard" (17). La identidad en el ámbito de lo Otro funciona entonces como una máquina de narrar; esa búsqueda de legitimidad pone en movimiento los motores de una máquina ficcional que construye, a través del relato, identidades diversas y móviles. Nuevamente, frente a la categoría monolítica de lo Propio catalán, lo Otro se define diverso, heteróclito y flexible.

Otro dispositivo que pone a funcionar la maquinaria de la ficción es el de los prejuicios de clase. Teresa, en tanto Propia, no duda de su versión de Manolo, e imprime sobre el Pijoaparte un personaje que se nutre de la bibliografía marxista. A través de su mitificación del proletariado, Teresa asume que Manolo es un obrero revolucionario que conspira contra el régimen de Franco: “-Es un obrero, ¿no? Estaba segura. -No tenía ningún interés en oír la respuesta" (128). Porque es Propia, Teresa cree tener la autoridad para construir una versión monolítica del joven del sur, y se configura como dueña de la verdad. En este punto, también se observa el manejo de la ironía del autor: 
- [...] Por favor, Teresa, no digas nada y yo le pediré que no vuelva más por aquí... Él es lo que es, pero es muy bueno, es como usted, muy así a veces, muy revolucionario, se enfada por cualquier cosa... Pero lo malo es que... yo creo que necesita esconderse, algunas veces, y por eso viene a verme. Sólo por eso. - ¿Qué quieres decir?

- [...] No me atrevo. Prométeme que no se lo dirás a nadie.

("La mujer, que echa sangre y alumbra, tendrá de las cosas de la vida un 'instinto' más profundo que el biólogo. El labrador tiene de la tierra una intuición más justa que un agrónomo diplomado", le había aclarado Simone.)

- Vamos, mujer, [...] ¿Por qué iba a esconderse tu hombre, y de quién?

Estaba casi segura de saberlo, pero deseaba una confirmación. Aparentaba indiferencia, con el libro abierto ante sus ojos y la mirada perdida entre líneas: ciertamente, leía entre líneas, atenta a las palabras de Marujita de Beauvoir, compañera envidiable de Manolo Sartre o Jean Paul Pijoaparte, como se prefiera. $(126-27)$

La estrechez de miras con la que Teresa impone una versión de Manolo a partir de la bibliografía comprometida es ridiculizada por Marsé. La cita de El pensamiento político de la derecha (1931), de Simone de Beauvoir, ubica irónicamente a Teresa en este espectro político, al hacer manifiesto su posicionarse en un lugar indiscutido de saber. Su "instinto", por otra parte, es incorrecto; el lector sabe desde la primera página de la novela que Manolo no es un obrero sino un ladrón, y participa de un pacto cómplice con la ironía del narrador. El cruce de los nombres de la pareja fundamental de la filosofía existencialista de los años cincuentacontemporánea a la época en la que se sitúa la novela - traza con líneas caricaturescas no solamente a Manolo ("Manolo Sartre o Jean Paul Pijoaparte") y a Maruja ("Marujita de Beauvoir") sino, sobre todo, a quien dibuja estas caricaturas.

Teresa no es la única que tiene prejuicios de clase. También Manolo asume que, por su extracción social, Teresa debe ser pura:

Tal fidelidad a una amarga presunción, a una idea que le costaba admitir, el esfuerzo que hubo de realizar para valorar moralmente a una muchacha de la categoría de Teresa, denotaban, por otra parte, hasta qué punto el murciano estaba todavía lejos de hallarse en disposición ideal de combate. Esto es: el muchacho se resistía a admitir que una señorita como Teresa fuese una vulgar desvergonzada. Y no porque él ignorase la desvergüenza de este mundo [...] 
sino porque su sentido de las categorías sociales había estado demasiado tiempo ligado a un sentido de los valores. (85)

Marsé explica los orígenes de este prejuicio de clase. Subraya que Manolo no puede separar la dignidad del dinero: “Él se plantea una cosa así como: para ser una persona digna y honesta en esta vida, tienes que ser rico" (Belmonte 28). Es por esto que Manolo cree que sólo casándose con Teresa puede abandonar los malos hábitos y convertirse en una "persona de bien”: "Él nunca fue eso que llaman un buen chico (ni probablemente tendría ocasión de serlo nunca, pensaba, a menos que se casara con Teresa); entonces, ¿por qué diablos se había comportado como tal en no pocas ocasiones, en nombre de qué y por qué, vamos a ver, se había dejado llevar a una situación de respetabilidad, de dignidad, y que no tenía salida?” (301).

Últimas tardes se configura como el primer paso en el lento proceso de debilitamiento de las fronteras entre lo Propio catalán y lo Otro en la obra de Marsé. Como ya ha observado Sherzer, no se logra la síntesis: la historia de Manolo y Teresa sólo se extiende durante el verano, Manolo nunca tiene un encuentro sexual con Teresa-porque, en tanto Propia, no puede, todavía, ser poseída por la Otredad-,${ }^{60}$ vuelve a robar una motocicleta y es detenido por la policía. Sin embargo, la rigidez del binarismo comienza a fragmentarse. En primer lugar, se sugiere la posibilidad del encuentro, a pesar de que no se concreta. Tanto Manolo como Teresa fantasean con esa posibilidad, y ambos insinúan - tanto en las reflexiones de Teresa como en los cromos de Manolo- que es posible. En segundo lugar, lo migrante y lo catalán se influencian mutuamente: a pesar de que no es claro qué sucede con cada personaje después de ese verano, durante su breve relación, Manolo y Teresa son, hasta cierto punto, transformados por el otro.

\footnotetext{
${ }^{60}$ En este punto, Sherzer observa que ese encuentro sexual que no se produce se carga de una misma importancia, pero de significados diversos, para Manolo y para Teresa. Para ella, implica desprenderse de los prejuicios de su grupo social; mientras que para él implica ingenuamente la salida de la miseria: "La diferencia de clases no va a dejar que Manolo penetre, ni en la alta sociedad ni en la misma Teresa. Tampoco ella podrá encontrar una definición más ancha que la que su clase le impone” (Juan Marsé 154).
} 
Teresa, en primer lugar, comienza a registrar la pedantería del circuito universitario: “Cuánto mejor no sería acogerse a ellas una vez más y hablar de cosas simples en el dulce y diminuto espacio de los alientos mezclados, en lugar de perder el tiempo aquí con esos pedantes!" (239-40). También comienza a desarrollar una cierta experiencia de vida, un conocimiento empírico que le permite desplegar una conciencia social más realista:

Es inteligente, atractivo, generoso, pero pícaro, descarado y probablemente embustero: se defiende como puede. Porque, ¡qué sé yo de los efectos rarísimos que ejerce la pobreza sobre la mente! ¡Qué sé yo del frío, del hambre, de los verdaderos horrores de la opresión que debe sufrir un chico como él si aún ni siquiera le he preguntado qué jornal gana, si nos empeñamos en no querer hablar del jornal de un hombre, sólo de su conducta [...], si hoy mismo, portándome como una marquesita estúpida que hace una pataleta ante su chofer, le he obligado a bajar del coche, si quería interrogarle en vez de ayudarle, si él es tan encantador, tan guapo, tan gentil y paciente conmigo! (265)

Hacia el final de la novela, Teresa se posiciona en otro lugar, más humilde, con respecto al saber: ya no es la dueña de la verdad, sino que se permite dudar de su conocimiento sobre materias que ella creía dominar. El fragmento muestra una multiplicidad de expresiones de duda (a partir de construcciones adverbiales como "probablemente" o "qué sé yo"; además de una preponderancia del uso del modo subjuntivo) como así también un nuevo registro del Otro como un par, factible de tener una palabra de tanto peso como la suya ("ni siquiera le he preguntado"). Registra, asimismo, la represión característica de lo Propio catalán ("nos empeñamos en no querer hablar"), como así también su propio lugar de privilegio (“marquesita estúpida que hace una pataleta ante su chofer").

La transformación de Manolo es también patente. En primer término, a nivel textual, durante el transcurso de su relación con Teresa, el personaje se va despegando de su alias; la mayor concentración de referencias a "el Pijoaparte" se encuentra en los primeros capítulos de la novela y en el final, cuando es detenido por la policía. En segundo lugar, se resquebraja la 
identificación entre el muchacho y su lugar de origen, al punto que comienza a sentirse discordante dentro de su propio territorio:

\begin{abstract}
"Quítame las manos de encima, marica", ordenó el otro. Manolo le escupió en el entrecejo, sin soltarle [...]. Manolo volvió a escupirle y luego lo soltó, repentinamente perplejo. En el fondo, la opinión del Jesús le tenía sin cuidado, moralmente hablando; y aunque el barrio entero la compartiese, también. Lo grave era que eso confirmaba aquella impresión de desfase y desintegración, la sensación de que en el barrio los acontecimientos habían empezado a desbordarse desde hacía algún tiempo, sin enterarse él, y lo mismo cabía pensar de los sentimientos de la gente. (212-13)
\end{abstract}

Este "desfase" que experimenta Manolo con respecto al Carmelo da cuenta de la mutua influencia, aunque limitada, que han tenido los personajes. Sherzer observa que la relación entre Teresa y Manolo prefigura una predialéctica, pues no existe una síntesis integradora. Sin embargo, reconoce que "hay algunos momentos en Últimas tardes donde quizá esa dialéctica se produzca" (Juan Marsé 242). Consideramos que los dos fragmentos citados se encuadran dentro de esta zona de ambigüedad.

Últimas tardes encarna así un primer paso tentativo en la contra-construcción de lo nacional catalán llevada a cabo por Marsé. A pesar de que la historia de Manolo y Teresa puede plantearse como asintótica por su fugacidad, es fundamental, en primer término, el registro de esa nueva figura migrante y su inclusión dentro del escenario catalán. A través de diversas estrategias discursivas, relevadas en el entramado textual, Marsé despliega sus estrategias narrativas. En primer lugar, textualiza al Otro migrante simultáneamente a su arribo a Cataluña, y da cuenta de una relativa antigüedad en el proceso, al situar los hechos de la novela en 1956. A nivel textual, asocia ciertos significados a esta Otredad (lo oscuro, lo arrogante, el saber empírico, la viveza, cierto uso desviado de la lengua, la carencia) y delinea aún una línea relativamente fija entre lo Otro y lo Propio. 
Además, define lo Propio catalán también a partir de ciertos significados (lo claro, lo elegante, el saber institucionalizado, la norma lingüística y el catalán, la propiedad, entre otros) aunque desde una perspectiva crítica, que se sirve de los procedimientos asociados a la ironía y al humor para ridiculizar su carácter monolítico. Esta mirada corrosiva, sumada a una voz narradora que suele ser favorable a la Otredad, plantea la relatividad de los valores asignados a los componentes de la dicotomía, que la hegemonía plantea como absolutos. Esto da lugar a otra de sus estrategias narrativas: tímidamente aún, se prefigura también un espacio gris, no todavía de mezcla, pero sí de mutua influencia y transformación. Es en este sentido que consideramos que la solidez de los bordes que separan a lo catalán de lo foráneo comienza a debilitarse.

En el próximo capítulo, nos detendremos en el análisis de la novela La oscura historia de la prima Montse, publicada por Marsé en 1970, luego del éxito de Últimas tardes con Teresa. La novela de 1970 puede interpretarse como un segundo paso en la fragmentación de las fronteras estancas entre lo catalán y lo migrante, pues hace visible la posibilidad del mestizaje. Esta viabilidad se textualiza con sus conflictos y tensiones específicos; sin embargo, presenta la idea de cruce—de espacios y de personajes—como factible y real. 


\section{Capítulo 3}

\section{La oscura historia de la prima Montse: hacia una apertura a un espacio de}

\section{hibridez}

En 1970, Marsé publica La oscura historia de la prima Montse, una novela bien recibida por la crítica, denominada "una de las mejores novelas del año" (Rico 36), y un "excelente, divertido e impresionante libro" (Domingo 242). La cuarta novela de Marsé confirma de este modo su lugar privilegiado en el circuito cultural de la época, al tiempo que rectifica popularidad: La oscura historia es también un éxito a nivel comercial. A pesar de esto, existe escaso trabajo crítico sobre esta novela en particular.

En este capítulo relevaremos las estrategias discursivas mediante las cuales Marsé monta ciertos significados asociados a lo catalán y a lo migrante en La oscura historia. Advertiremos que algunos significados se continúan con respecto a Últimas tardes (lo oscuro y lo claro, la arrogancia y la delicadeza, el dinero y la exclusión, la represión sexual y la sexualización), mientras que otros se potencian, como el del seny. Sugeriremos, también, que la gran estrategia narrativa de La oscura historia radica en la configuración de zonas híbridas, que poseen simultáneamente características de ambos espacios y ponen en cuestión la separación tajante entre ellos. Consideramos que la estructuración de estas zonas prefigura el segundo paso en la construcción de la idea de nación que subyace al trabajo de Marsé. Además, la crítica social, sostenida en un tono irónico, se torna en esta novela menos sutil, y se articulan las ideas de lo Propio con un sistema político y uno religioso determinados.

Al igual que en Últimas tardes, el título de la novela adelanta una de las líneas argumentales de la historia. Situada en Barcelona, La oscura historia relata dos historias en dos planos temporales. En primer lugar, narra el reencuentro de Paco Bodegas—el narrador- 
y su prima y amante Nuria Claramunt, en 1970. Paco y Nuria se reúnen a escondidas del marido de Nuria, Salvador Vilella, en la casa en ruinas de la familia en Barcelona, y conjuran un plan para que Nuria deje a su esposo y huya con su primo. A su vez, durante sus encuentros, la pareja rememora una segunda historia, ocurrida en 1959, que tuvo como protagonistas a Montserrat Claramunt—la hermana de Nuria-y a Manuel Reyes. Marsé recupera en esta novela la figura del Pijoaparte, el inmigrante del sur de Últimas tardes con Teresa, y retoma el relato de sus andanzas al final de su condena por robo. Durante los últimos meses de su encierro, Manuel conoce a Montse, una joven proveniente de la alta burguesía catalana que es voluntaria de la orden seglar de las Visitadoras a la Caridad. Montse intenta por diversos medios reinsertar a Manuel en la sociedad y termina enamorándose del joven. Su familia se opone a esta relación, y le ofrece a Manuel un buen puesto y dinero a cambio de que éste desaparezca de la vida de Montse. Al descubrir su partida, Montse, que está encinta, se suicida arrojándose de un puente. Poco tiempo después, Paco abandona el país, y regresa once años más tarde. La oscura historia sugiere también una tercera línea argumental, sucedida antes que la de Montse y Manuel, que involucra a Conchi Claramunt, la madre de Paco. Este relato es fragmentario y lateral, pero cobra especial importancia al observar las coincidencias entre la peripecia vital de Conchi y la de su sobrina, Montse.

Hay varios puntos en común entre Últimas tardes y La oscura historia, además del protagonismo de Manuel Reyes. Existen similitudes en la trama central, como así también en los espacios en los que se desarrollan las acciones: el barrio de Gracia, la casona familiar. Si bien Teresa y Montse predican mensajes diferentes, y la militancia universitaria de Teresa se textualiza con una ingenuidad risible mientras que la de Montse es más implicada, ambas son idealistas, y asumen un compromiso para transformar el mundo. Esto ya fue advertido por el propio Marsé, quien sostiene que las dos tienen en común "una cierta romántica capacidad o voluntad de ensoñación, de adecuar su ideal de la personalidad-reprimida por el entorno 
familiar y social, la educación recibida y la estrategia moral de una clase —a una realidad social anhelada por ellas, más justa y más libre, pero que todavía no existe" (ctd en Turpin 52). El novelista agrega que ambas muchachas se anticipan a su tiempo y que, por eso, la sociedad y la familia "les pasan factura" (52). Esto es también percibido por Mainer, quien afirma que Montse tiene dos enemigos principales: su estrato social, cuya hipocresía la lleva a la ruina, y la impenetrabilidad recelosa de lo Otro, que la entrega indefensa al mundo hostil de su origen. El crítico considera que La oscura historia puede plantearse como una complejización de Últimas tardes, pues en ésta Marsé juega sarcásticamente con la contraposición de los dos ámbitos sociales, mientras que con la novela de 1970 pasa de la comedia al drama trágico ("El vengador" 248).

Con respecto al lenguaje, la novela presenta el estilo sencillo y accesible al lector común ya relevado en Últimas tardes. Es frecuente, también, un cierto lirismo, sobre todo asociado al personaje de Montse. También hay en exceptuadas ocasiones un estilo directo vinculado a la crítica social; al regresar de su conferencia, Paco le pregunta a Salvador:

... por qué insistían tanto en acusar de violentos a los pueblos subdesarrollados y oprimidos que intentan rebelarse: ¿acaso no es una forma de violencia, le pregunté, el poder que ejercen sobre ellos las minorías privilegiadas? ¿No es una forma de violencia la ignorancia, el hambre, la miseria, la emigración laboral, los salarios insuficientes, la prostitución organizada, la discriminación intelectual, etc.?, le dije. ¿Por qué nunca llamáis violencia a todo eso, reverendo? (48)

Este tono crítico, sutilmente disperso en la densidad textual, logra al mismo tiempo hacer visible una crítica sobre la sociedad contemporánea y pasar desapercibido. Al igual que en Últimas tardes, la dimensión crítica por antonomasia es la del humor y la ridiculización.

De hecho, el tono paródico se intensifica con respecto a la novela anterior. En primer término, son usuales los neologismos, que crean un efecto de humor al poner en el mismo plano 
lingüístico dos elementos discordantes. Así, en la primera jornada de un curso de cristiandad al que asiste, Manolo observa un "snack-masía" (149) atendido por un viejo masovero. En segundo lugar, es frecuente un tono rimbombante, que se carga de sentido paródico al construirse con palabras inexistentes: "El corintelladismo es aumentativo y nefasto, conforme, pero más lo es el raphaelismo televisivo y mariconil. Más manuelaznarismo le hace falta a nuestra prensa" (46). Este tono burlón suele relacionarse con el personaje de Salvador. Las referencias a lo popular, por otro lado, son constantes: Corín Tellado y Raphael remiten a la cultura de masas. En tercer lugar, existe en La oscura historia parodia en el plano fónico. Sherzer registra un cierto pasaje de la novela en el que se subraya "el sentimiento del xarnego hacia las diferencias fonológicas (y de allí, sociales) entre el castellano y el catalán” (Juan Marsé 235). El crítico se refiere puntualmente al baile de las debutantes, al que asisten: "De izquierda a derecha, empezando por arriba: ... señores de Barrancós, Comamella, Juncadella y Gratacós; Llop, Dot, Bachs, Dachs, Codorniu, Llofriu, Salat y Rafat; Climent, Manent y Prudent; Sert, Mon, Nin, Amat, Serrat (Don Oriol), Malet y Fatjó; Conill, Bofill, Gassol y Bassols, Faixat, Cotonat y Llapat; Bufalá, Pahíssa, Pujol y Despujol” (Marsé 224). ${ }^{61}$

La crítica coincide en subrayar la ridiculización que Marsé hace de las clases altas de Cataluña en La oscura historia. Así, José Domingo destaca la precisión con la que el novelista retrata el "fariseísmo de la burguesía catalana" (240), mientras que Gustavo Martín Garzo afirma que Marsé entabla un diálogo con el mundo, y lo critica de un modo feroz (251). Como observa Danielle Pascal-Casas, Marsé también dirige su artillería sobre la institución clerical, y la alianza que este sector (que proclama defender a los desposeídos) hace con la burguesía local para asegurar la reproducción de un orden social injusto (122). José Carandell observa que Marsé no solamente ataca al racismo catalán enquistado en la clase burguesa, sino también a la religión y al trascendentalismo (237). También Cuenca observa esta alianza, en la que la

\footnotetext{
${ }^{61}$ La mención velada a Jordi Pujol no es casual, a la hora de definir el ámbito de la catalanidad.
} 
burguesía catalanista se caracteriza a través de la impostura de una cierta sensibilidad social que se muestra a través de su fe católica (340). Así, el sector de la iglesia católica catalana se beneficiará del poder de la burguesía, mientras que ésta negará su mala conciencia “con obras de beatería y vagas llamadas a la solidaridad entre clases" (Martín Garzo 250). La alianza entre estos dos sectores es tal que Rosemary Clark acuña la expresión "Catalan Catholic Nationalism" para unificar a estos dos grupos bajo un mismo término (4).

Con respecto a esta alianza, Francisco Canales observa que la historia reciente catalana ha tendido a borrar la colaboración de una parte de las clases altas locales con la Iglesia- e, indirectamente, con el franquismo. El historiador sostiene que la mirada posfranquista sobre la historia de Cataluña intenta establecer una interpretación artificial de los hechos:

El discurso predominante en la divulgación histórica (incluida la enseñanza), las memorias y los medios de comunicación presenta al franquismo como un régimen no sólo ajeno, sino contrario a la realidad catalana $\mathrm{y}$, por ende, irreconciliable con la catalanidad. Esta imagen oculta la notable colaboración que el régimen encontró entre sectores claves de la sociedad catalana como la derecha, la burguesía y la Iglesia. (260)

Canales apunta que la derecha y un sector de la burguesía catalana tejieron alianzas con los sectores eclesiásticos para salvaguardar su lugar de poder dentro de la sociedad. Afirma que, si bien estos sectores defendían una identidad catalana diferente de la española, esta resistencia era solamente de tipo cultural y muy tradicionalista. Añade que el tipo de manifestaciones culturales específicas "tenía[n] un marcado sesgo tradicionalizante y católico que respondía a las características de sus impulsores, vencedores en la guerra" (278). Por el contrario, Balcells opina que el catalanismo encontró en el cristianismo un lugar de resistencia, pues "era el menos fascistizante de los elementos legitimadores del franquismo y la omnipresencia y potencia de la religión católica era tal que sólo desde ella era viable ir más allá de los reducidos núcleos clandestinos" (188). De este modo, la coalición Iglesia-burguesía catalana vigilará las fronteras 
del ámbito de lo Propio, y procurará evitar sus fisuras. Sin embargo, veremos más adelante, estas fisuras se hacen cada vez más evidentes, y se concentran ya no solamente en la figura de Manuel—el inmigrante del sur—sino también, y fundamentalmente, en la del narrador mestizo, Paco Bodegas.

Por otro lado, algunos autores coinciden en subrayar una transformación dentro de la Acción Católica, movimiento seglar "equiparado en la mentalidad bélica de la posguerra a un ejército a las órdenes del clero" (Moreno Seco 261). Aunque en un principio esta institución se alinea con la iglesia tradicional, en la segunda mitad de los años sesenta recoge las influencias del Concilio Vaticano II y se abre a una actitud de diálogo y de inclusión (Moreno Seco 262). Así, puede alinearse el compromiso seglar de Montse a esta nueva perspectiva, lo que la confirma como adelantada a su tiempo y, por lo tanto, incomprendida por su medio. Paco, de hecho, registra esta realidad cuando le pregunta a Salvador, en 1970, cuál es la nueva línea de la orden. Salvador responde que es la del "diálogo, la convivencia, el aggiornamento" (35), frente a lo que Paco afirma: "-Cruel ironía la del destino -dije. -Recuerdo que a Montse la llamabais borrega y tonta por situarse hace ocho años en esa línea que ahora, precisamente, los nuevos vientos ecuménicos os recomiendan" (35).

Cierto sector de la crítica afirma que Marsé rescata a Montse del sarcasmo con el que ilustra a su grupo. Domingo, por ejemplo, sostiene que Montse es "la sola incorrupta, culpable de haber creído, con una ingenuidad rayana en la bobería, en las prédicas de una moral cristiana" (241). El propio Marsé también manifiesta su simpatía por este personaje, y hace visibles las contradicciones entre apariencia y realidad que atraviesan su ámbito de origen. Afirma que Montse "lucha hasta el final por mantener aquel espejismo de bondad cristiana que le inculcaron de niña y que, de pronto, sus mismos padres y educadores pretenden destruir en defensa de unos intereses materiales" (ctd en Turpin 53). 
La oscura historia cuenta con veintiséis capítulos numerados, relativamente breves. Cada capítulo tiene un título, que resume, por lo general en un tono paródico, la materia que se leerá a continuación. Algunos de estos títulos implican una crítica al ámbito de lo Propio en sí mismos (el 11 se titula "Donde la fanfarria moralizante hace agua"), mientras que otros parodian otros discursos, como el religioso (el 7 se titula "El que debe ser regenerado"). Atención especial merece el título del primer capítulo, "Detrás de la fachada", que concentra la intención crítica del autor, y hace visible las contradicciones entre apariencia y realidad que consolidan la hipocresía de la burguesía catalana. En el capítulo 15 se inicia una interrupción en la trama central, en la que un narrador omnisciente relata, entre los capítulos 17 y 19, las peripecias de Manuel en un curso de cristiandad al que Montse le pide que asista, asegurándole que existen posibilidades de generar contactos para conseguir un buen empleo. En esta sección la crítica hacia la institución religiosa se hace más densa, más irónica y más cruda. Los cruces en los planos temporales de las dos historias son frecuentes en el interior de un mismo capítulo, aunque hay algunos capítulos que se desarrollan exclusivamente en 1959, o en 1970.

Con respecto a la figura del narrador, Marsé profundiza aquí la técnica del perspectivismo que vimos en Últimas tardes. Carandell afirma que La oscura historia puede pensarse como una reformulación de la novela anterior. Agrega que una de las líneas argumentales de la novela, la historia de amor de Manuel y Montse, replica la de Manolo y Teresa. Sin embargo, observa que La oscura historia complejiza los mecanismos de Últimas tardes, al presentar la historia de sus personajes a través de una segunda línea argumental, con dos personajes paralelos, Nuria y Paco, que rememoran la serie de hechos que involucraron a Manuel y Montse (235). También es Paco quien rememora, de manera fragmentaria y secundaria, la historia de su madre. 
De este modo, Marsé prefigura a un narrador en primera persona, Paco, que conversa con una interlocutora (Nuria), quien muchas veces discute y modifica su versión. En el tercer capítulo, Nuria corrige la versión de Paco y afirma:

-Pues no [...]. No ocurrió exactamente como dices. Primero que tú mal podías conocer la parroquia, todavía no vivías en Barcelona. Y luego, siempre que hablas de mi hermana te dicta la mala conciencia, se te cambia hasta la voz [...]. Sería tranquilizador, lo comprendo, pero no puedes darle la vuelta al pasado como su fuese un calcetín. Lo que pasa es que tú ves las cosas a tu modo.

-Por supuesto.

-Pues es un curioso modo de ver las cosas, Paco. Lo que no viste lo suples con la imaginación. No juegas limpio. (23)

Clark denomina a esta técnica "dispositivo de narración dual" (device of dual narration) (45) y afirma que le permite al novelista una exploración más extensiva del potencial que tiene la narración para crear historias posibles - aunque no necesariamente ciertas-, al tiempo que resalta la conciencia del narrador sobre la falibilidad de su relato. De este modo, la técnica de la narración dual pone de manifiesto el carácter de versión de toda historia, y hace visible la posibilidad de que sea contrastado por una versión diferente (Clark 45).

La confrontación del relato no siempre es llevada a cabo por Nuria, muchas veces es el propio Paco el que duda de su memoria. Afirma en el capítulo noveno: "[L]a memoria me falla para todo aquello que no estaba al alcance de mis manos" (79). También son frecuentes las referencias a sus olvidos: "Montse me puso la mano al hombro y me hizo volverme para presentarme al tipo, dijo que se llamaba Rafael, o algo así, lo he olvidado" (112). Este tono de incerteza aporta a la novela, además, apariencia de autenticidad.

Al plantear la idea de versión subjetiva por sobre la de Historia, Marsé socava la rigidez de los binomios historia/ficción, y verdad/mentira y plantea la posibilidad de que el discurso histórico no sea una verdad inamovible. Esto ya fue observado por Hayden White, quien afirma que a pesar de que los temas son diferentes para el escritor de ficción y para el historiador, los 
procesos de relato son similares. White destaca que, aunque los novelistas tratan con elementos imaginarios y los historiadores con eventos reales, ambos deben utilizar las mismas estrategias tropológicas. El historiador debe valerse de los mismos modos de representación del novelista para hacer de un registro histórico primario, un discurso coherente (125). Por otra parte, White también se detiene en la dimensión política del lenguaje, y afirma que toda construcción lingüística se encuentra atravesada por la ideología. Para el historiador, es indispensable registrar que no solamente la interpretación de los hechos, sino también el mero uso del lenguaje obliga a asumir un cierto posicionamiento ético, ideológico y, más ampliamente, político (129).

Al poner el ojo en el carácter subjetivo de todo discurso histórico, Marsé también erosiona la definición unívoca del relato de nación. White, de hecho, rescata la tradición retórica y afirma que no existe un modo correcto de representar el mundo, sino que ese modo de representación aceptado es impuesto por quienes ostentan el poder. Para White un cierto significado es siempre producido: una verdad es siempre engendrada, no hallada (ctd en Domanska 96). En esta línea, la idea de versión abre la duda, en primer término, sobre quién tiene la autor-idad de construir el relato que delimita los bordes de lo catalán. Por otra parte, al asumir cualquier discurso histórico como versión, se visualiza el carácter hegemónico de cualquier relato de nación y se abre la posibilidad de construir otras versiones contrahegemónicas sobre qué es lo Propio y qué es lo Otro, y cómo son los bordes que los separan.

La memoria inaugura un relato, afirma Marsé, pero ese relato es falible, dirigido, que no puede decirlo todo, y por eso omite, calla y selecciona. Fina Birulés afirma que una condición necesaria para el ejercicio de la memoria es el olvido; a diferencia de las inteligencias artificiales, la memoria humana "al recordar siempre destruye" y organiza la sucesión de sucesos a partir de poner el foco sobre algunos hechos y suprimir otros (9). También Pierre 
Bourdieu se detiene en la falibilidad de la memoria, y afirma que en todo relato autorreferencial hay una organización dirigida a dar sentido, a "extraer una lógica a la vez retrospectiva y prospectiva [...] estableciendo relaciones intangibles, como la del efecto con la causa eficiente, entre los estados sucesivos" (75). El relato de la memoria es, además, lenguaje_ya no vivencia inmediata $-\mathrm{y}$ prefigura, por lo tanto, un lenguaje autorizado para decir lo Propio. Felicity Nussbaum destaca la importancia del nuevo historicismo en el cambio de perspectiva sobre los géneros de la memoria: los modos de acceder a la realidad tangible son siempre mediados por lo linguiístico y por lo tanto, por lo ideológico (12). Es en este sentido que consideramos la importancia de las estrategias discursivas del novelista, que teje significaciones disidentes de la norma en el entramado textual.

El hecho de que la narración de la historia de Montse y Manuel se apoye en la memoria subvierte la idea del narrador como figura autorizada, dueña de la verdad de lo que se narra. Currie Thompson observa este mecanismo en otro texto de Marsé, y afirma que, de esta manera, el lector no puede elaborar conclusiones definitivas sobre los acontecimientos relatados (155). La oscura historia es, según Cuenca, la primera novela de Marsé en la que "la memoria (y su compleja y confusa naturaleza) [surge] como asunto central en la obra de Juan Marsé" (341). El propio Paco afirma, en el tercer capítulo de la novela: "La memoria lo es todo para mí. Tanto recuerdas, tanto vales" (31).

Muchas veces, Paco elige la segunda persona para reflexionar sobre sí mismo. En estas reflexiones, Marsé es duro con el narrador, aunque rehúye de los procedimientos paródicos, y en este sentido lo rescata de la crítica mordaz. No se apunta a la burla, sino a la conmiseración:

Has conservado siempre muy agudo lo que podríamos llamar el oído musical de la familia, una rara habilidad para acoplar la voz a muchos y variados acordes o para improvisar hipócritas dúos confidenciales en espera de la ocasión propicia para lanzar el do de pecho seguido del aria sosegadora. Y de ello supiste sacar partido con Nuria: moralizando como un bellaco de provincias que eres, modulando tu hermosa voz de joven diácono ante su adicto auditorio femenino 
y pueril, vendiendo falsos paraísos de felicidad e insinuando miserablemente otros placeres escondidos en la manga, en sucesivos encuentros le sacas a la prima los motivos de aquella violenta tristeza (75).

Paco es un narrador, entonces, atípico. Es también diversa su colocación en el mundo, debido a su origen. Es el único hijo de la hermana del padre de Nuria y Montse, Conchi Claramunt. En 1939, Conchi huyó con un alférez de Córdoba, que luego trabajó en el cine como extra, y tuvo con él a Paco, nacido en Madrid. Él se considera un "hijo del pecado" (52), mientras que Mainer opina que Paco es "el lunar biológico en la inmaculada estirpe altoburguesa de los Claramunt" (“El vengador” 246).

A pesar de que un sector de la crítica identifica a Paco con el universo migrante, Bodegas es un personaje que se encuentra a mitad de camino entre lo catalán y lo Otro. La inclusión de este personaje se consolida como una de las estrategias narrativas de Marsé en su contra-construcción de lo nacional catalán. Si en Últimas tardes el novelista sugería la posibilidad de una zona incipiente de mutua transformación entre los dos espacios y registraba la presencia del inmigrante en el paisaje de lo nacional, en La oscura historia da un paso más y propone la posibilidad del mestizaje. Sin encuadrarse por completo en ninguno de los dos espacios, Paco encarna características de ambos, y condensa significados asociados con los dos ámbitos. Nos referiremos a este tema en profundidad más adelante.

Por otra parte, La oscura historia también establece vínculos con el cine. Las referencias al universo cinematográfico operan a través de la separación de los espacios de lo catalán y lo sureño. Conchi Claramunt, en primer lugar, es script de cine, y el padre de Paco fue un "oscuro actor de cine sin dinero ni porvenir" (51). Luego de la muerte del padre de Paco, Conchi entabla una relación con un "activo productor", y luego con un "apasionado y disparatado director de origen franco-argentino" (53), para más tarde casarse con "un fotógrafo de provincias" (56). El cine funciona también como excusa para el regreso de Paco a Barcelona: 
Paco, que es ayudante de dirección de una empresa francesa, llega a la ciudad para conseguir, por intermedio de Salvador, un permiso para filmar. A su vez, la primera cita de Nuria y Paco es en un cine, y también Montse y Manuel van a veces a "un cine de barrio" (203). Por otro lado, el cine también opera para separar a Salvador del resto de los personajes, pues dice "que apenas iba al cine, que no tenía tiempo" (33), además de afirmar que el cine es "algo tan ajeno a la naturaleza de nuestras pasiones o virtudes" (32).

El tema del cine también opera para visibilizar el clima de censura de la época, en una crítica política velada. Paco hace referencia a las dificultades de circulación de ciertas películas francesas en España—“Vosotros no podéis verlo todavía” (33)—lo que es relativizado por Salvador: “[H]ace poco pude ver Viridiana en una sesión especial con coloquio organizado por sacerdotes" (33). La ridiculización del personaje de Salvador se da a través del hecho de que éste minimice la censura por el hecho de que un grupo muy reducido de personas (burgueses y clérigos) pueda acceder a ver la película de Buñuel. De un modo lateral, Marsé también textualiza, a través del tema del cine, la alianza entre estos sectores y la censura franquista.

Las relaciones intertextuales con la cultura popular también se dan a través de ciertas vinculaciones con revistas, como Playboy u Hola. El diálogo con esta última se da no solamente a través de la referencia a la colección encuadernada de Nuria, sino también a través del uso de un registro lingüístico específico a la hora de retratar ciertas situaciones: "En el marco incomparable del Club de Tenis La Salud y bajo una maravillosa noche estival cuajada de estrellas se celebró con extraordinaria brillantez la verbena a beneficio de la Congregación de Señoritas Visitadoras, de la que es activa secretaria la señora Carmen Reixach de Joveller (Menchu de soltera)" (223). La parodia del estilo propio de este tipo de publicaciones, sumada a la abundancia de apellidos autóctonos de la secretaria delimita una idea de lo catalán que se lleva a cabo a través de la ridiculización. 
Al igual que Últimas Tardes, La oscura historia presenta ciertos personajes incuestionadamente vinculados con la catalanidad, y otros personajes que, sin lugar a dudas, se asocian a lo sureño. Estos personajes asumen significados relativos a estos dos espacios. La familia Claramunt — excluida Montse — encarna cabalmente los significados vinculados a lo catalán:

Esta familia se compone de gente respetable y creyente, fabricantes de tejidos de seda, establecida desde hace tres generaciones en la ex villa de Gracia. Aunque hayan ganado mucho dinero y hoy desplieguen brillante vida social, los Claramunt forman en cierto modo un Orfeó, una modesta, fraternal y graciense masa coral, y lo prueba el hecho de que, cuando discuten entre sí por cuestiones de dinero, es como si cantaran: hay siempre una sutil armonía que despunta cautelosamente bajo el conjunto de voces, unos acordes profundos y cadenciosos cuyo secreto pertenece por entero a la mejor tradición coral y mercantil catalana [...]. (51)

Una de las marcas textuales de la catalanidad de los Claramunt se da en la referencia a la antigüedad de la familia en el barrio, sostenida no solamente en la construcción preposicional "hace tres generaciones", sino también en la selección del nombre antiguo del barrio de Gracia, previo a la llegada de la ola inmigratoria. Otra marca textual que confirma su origen catalán se da en la comparación con el Orfeo, tradicional sociedad coral catalana fundada en 1891 e impulsora de la construcción del emblemático Palau de la Música. El Orfeó Català refleja la voluntad de promover la música catalana erudita y la popular y apunta a difundir el folklore tradicional y la música culta autóctona (Millet 142). Con respecto al Palau de la Música, Lluis Millet afirma que encarna "nuestra tradición musical más inmediata" (140). En este sentido, el Orfeo y el Palau se configuran como estructurantes de un discurso nacional específico, que organiza una cierta selección de piezas musicales consideradas oficialmente catalanas.

Además, la familia Claramunt se inserta en la tradición “coral y mercantil catalana”, asociando en clave irónica el coro principal de Cataluña con el estereotipo de pueblo 
comerciante. Se asocian con la riqueza material, visible a través de referencias como "mucho dinero" o "brillante vida social". La comparación con el Orfeo se combina con el significado relativo a la riqueza y da lugar al comentario, en clave irónica, de que cuando hay un conflicto en esa familia, es de dinero. Esto confirma el lugar de importancia que tiene el dinero en lo Propio catalán, lo que muchas veces entra en contradicción con otro significado asociado a este espacio, el de lo religioso ("respetable y creyente") y pone de manifiesto la hipocresía que caracteriza a este grupo.

Uno de los personajes que asume cabalmente los significados del espacio de lo Propio es Nuria, quien ya desde su nombre (muy popular en Cataluña) se inscribe en este ámbito. Cuando Paco regresa por primera vez a Barcelona, a los veinte años, se encuentra con Nuria:

[A]l volverme hacia la puerta del salón, una nieve soleada y deslumbrante me ciega: una pierna levantada al aire, por detrás, el cuerpo hacia delante y el brazo extendido con la raqueta en la mano como si pretendiera devolver una sorprendente dejada junto a la invisible red [...]. Una jugadora de tenis, una preciosa muñeca vestida de blanco me observa con aire divertido, balanceándose sobre un pie. No tendrías más de dieciocho años, aún te veo, llevas una cinta roja elástica en el pelo, lacio y partido en dos y de hermoso color castaño, y zapatillas de tenis, falda y blusa blancas y un leve jersey echado sobre los hombros. (66)

La cita condensa una multiplicidad de vocablos vinculados a lo claro: no solamente Nuria está vestida de blanco, sino que su entrada en la casa es "una nieve soleada y deslumbrante". Aunque Paco, que es quien habla, tiene cierta presencia textual en la cláusula adverbial que inicia la cita, Nuria ocupa siempre el lugar de sujeto-ya sea en 1959, a través de la tercera persona, o en 1970, a través de la segunda—, lo que se equipara con el rol principal que ocupa también a nivel social. Paco, por otra parte, suele ocupar la posición de objeto, lo que es también compatible con su lugar en la sociedad. 
La abundancia de términos asociados a la mirada se asocia con el lugar erotizado que ocupa Nuria para el narrador. Laura Mulvey analiza la importancia de la mirada sobre el cuerpo femenino en el cine comercial, y considera el acto de mirar desde una perspectiva psicoanalítica. Resalta las correspondencias entre lo activo/masculino y lo pasivo/femenino, y considera que esto refleja la desigualdad de género. Afirma que el placer de mirar registra un sujeto observador varón que mira a un objeto de esa mirada mujer, cosificada. Sostiene que "la mirada determinante del varón proyecta su fantasía sobre la femenina, a la que talla a su medida y conveniencia" (370). Añade que esta proyección es tan poderosa, que el cine comercial configura a la mujer como objeto de exhibición, que es contemplada y mostrada al mismo tiempo "con una apariencia codificada para producir un impacto visual y erótico tan fuerte que puede decirse de ellas que connotan 'para-ser-mirabilidad' (to-be-looked-at-ness)" (370). La idea de la "muñeca" para caracterizar a Nuria pone de manifiesto el hecho de que su retrato se enfoca en su género, por lo general desde un lugar estereotípico. Esta perspectiva sobre este personaje se sostiene a lo largo de toda la novela.

En un primer momento, la textualización de Nuria es metonímica, lo que es coherente con la mirada erotizada de quien la retrata. Mulvey registra este procedimiento también en el cine comercial — las piernas de Dietrich, el rostro de Garbo-y afirma que integran dentro de la narración un erotismo diferente, disruptivo. Sin embargo, la fragmentación del cuerpo de Nuria es breve, ya que, luego de enumerar sus partes, se sintetizan en dos expresiones que la retratan de forma completa: "una jugadora de tenis" y "una preciosa muñeca vestida de blanco". Estos dos sintagmas nominales se asocian también con los significados ya relevados de la elegancia y de la propiedad material. El tenis es un deporte elitista en la península ibérica.

En cambio, Manuel concentra los significados asociados al espacio de lo Otro. Es, en primer término, moreno: “Algo en la piel del chico retiene su mirada, algo que de momento no acierta a penetrar; la almohada es un guiñapo casi humano en los morenos brazos encendidos, 
casi rojizos" (127). La relevancia del color de la piel de Manuel se replica en la sintaxis, en tanto funciona gramaticalmente como sujeto de la oración, en la que Montse, que es quien lo mira, queda relegada a la función de objeto. Esta pasividad es quizá una anticipación: no es Montse la que mira, sino Manolo el que la hace ver. Su experiencia con Manolo le hace comprender mejor la hipocresía que corroe su espacio de origen. Paco le comenta a Nuria que "su hermana no fue engañada por aquel charnego aparentemente desvalido, sino desengañada, lo cual es muy distinto" (128). Será también Manuel quien la inicie en el descubrimiento de su sexualidad. Sherzer sostiene que es él quien "le proporciona el camino hacia la autorrealización y el escape de la represión sexual” (Juan Marsé 148).

El personaje del Pijoaparte también se asocia con la peligrosidad y la ambición:

Tras ella, el difuso resplandor rojo coral en el vaho de los cristales de la taberna, como rescoldos encendidos en un profundo horno, podía ciertamente pasar por el del infierno. Pero él, que había salido de allí un poco antes y la precedía unos metros, acababa de cruzar frente a mí como una sombra y apenas me fijé, porque no conseguía relacionar (era la segunda vez que me ocurría) su juventud con mi prima. Pero al oír que Montse me llamaba, también él se volvió y entonces surgió de improviso a mi derecha, por la espalda. Iba con las manos en los bolsillos, lento y silencioso, algo encogido de hombros y con aquella sonrisa como un cuchillo entre los dientes [...]. Ahora que mi curiosidad le unía definitivamente a las penas y trabajos que Montse se tornaba por él, podía al fin calibrar de cerca el poder de su atractivo, aquel sordo clamor por antiguos tributos insatisfechos que parecía emanar de sus facciones duras, una oscura memoria de iniquidades y olvidos que no se conformaba con el reconocimiento sino que exigía reparación, y cuya expresión física (aquellos ojos, aquella frente y aquel pelo que había de estremecer la misma entraña de los Claramunt) debía de ser lo que por entonces aún inspiraba en mi prima una mezcla de sentimientos equívocos.

Estrechó mi mano aplicadamente, con rebuscada gentileza pero sin calor; seductora manera de estrechar la mano que esconde el puñal. (196-7)

Se observa un campo semántico vinculado a lo oscuro, intensificado ahora con una asociación con el infierno. El retrato del personaje plantea una relación intertextual con el género policial o el de terror: surge "de improvisto", "por la espalda" y tiene un caminar taciturno. La figura 
del cuchillo se duplica, vinculándose a su sonrisa y a su mano. Se contraponen entonces dos elementos: por un lado, la sonrisa y el estrechar de manos suelen vincularse a una idea de cordialidad. Este significado es reemplazado por otro, definido a través del recurso de la comparación con un objeto filoso, que construye la doble idea de amenaza y de traición.

Se advierte así que La oscura historia intensifica algunos de los significados ya asignados a lo Otro en Últimas tardes. Un ejemplo alternativo de esto se observa en la asociación entre la Otredad y el significado de la ambición. Lo que antes era la "coquetería de los ambiciosos superiores" es ahora un reclamo sostenido en la codicia. Su atractivo, antes juvenil, es ahora "poderoso", reflejado en sus facciones "duras". Concentra la consciencia de la desigualdad, que a nivel textual se manifiesta a partir de términos y sintagmas vinculados a la impotencia ("sordo clamor", "tributos insatisfechos", etc.).

La Otredad es también representada por otros personajes menores, y por los juicios que diversos personajes tienen de los sectores provenientes del sur. Así, en las primeras páginas de la novela, la Jeringa—quien, en Últimas tardes había denunciado a Manolo-encarna el significado sexual asignado a la charneguía:

Las demás, jadeantes y sudorosas, miran de reojo a la charneguita, su paciencia y su tristeza, aquel aire suyo de haber jugado mucho con chicos: indefensa prisionera de alguna banda de trinxas del barrio, parece haberse dejado hacer algo a cambio de su libertad. Ahora la ven avanzar por el campo [...]. [T]odas se vuelven y la ven balanceándose un poco sobre sus blancos zapatos de tacón escandalosamente alto para su edad. (14)

Se observa entonces el juicio de las mujeres catalanas sobre la muchacha. Su corta edad se textualiza en el diminutivo "charneguita", que organiza una idea de desamparo configurado en el adjetivo "indefensa" y en la construcción pasiva "haberse dejado hacer algo". El juicio de las compañeras de Nuria se concentra en el adverbio "escandalosamente", que resume las ideas de clase sobre la altura "apropiada" para los zapatos de una muchacha. También se advierte en 
el término "trinxas", palabra catalana que designa a las personas de clases menos privilegiadas. María Lugones observa que históricamente se caracterizó a las mujeres blancas europeas como sexualmente pasivas, lo que colocó a las mujeres de la Otredad en un lugar sexualmente agresivo (96). Recupera el trabajo de Le Espíritu, quien afirma que las representaciones de género y sexualidad están muy presentes en la enunciación del racismo, el que sitúa a las mujeres subalternas en un lugar hipersexuado y, por lo tanto, plausible de desprotección (98). En la asunción de que "parece haberse dejado hacer", y en la vacuidad de significado de "algo" también puede verse el prejuicio de clase sobre la sexualización del espacio de lo Otro, además de la asunción de su posición desprotegida. La expresión visibiliza también la imposibilidad de nombrar lo sexual (“algo") característica de la represión burguesa. El prejuicio de las compañeras de Nuria replica la mirada prejuiciosa de lo catalán sobre lo inmigrante que se comprueba en otros sectores del texto, en el que se refieren a "la pinta de": "Tenían todos la pinta inconfundible de los golfos del Guinardó, oscuros, pequeños...” (114). La oscuridad nuevamente se ve asociada a este grupo social.

A pesar de que ciertos personajes se encuadran exclusivamente dentro de la catalanidad o lo sureño, la estrategia narrativa de mayor relevancia que despliega Marsé en esta novela es la de la inclusión de otros protagonistas que se ubican en distintos puntos entre lo Propio catalán y lo Otro, lo que da cuenta de la fragilidad de las fronteras que separan estos espacios. Ahora propone la posibilidad de un continuum — ya no de una oposición binaria, de bordes fijosentre los dos ámbitos, y sitúa a dos personajes en esa zona de intersección. Montse proviene de la alta burguesía catalana y, sin embargo, recorre los espacios de los migrantes, conoce sus problemas y se compromete con ellos. De hecho, termina renunciando a su espacio y se instala en la pensión de Manuel, de quien queda encinta. Paco, en segundo término, es un personaje mestizo, hijo al mismo tiempo de lo Propio y de lo Otro, nacido en Madrid. Dentro del continuum, Montse se moviliza de lo catalán hacia lo sureño; mientras que Paco llega desde 
fuera para recorrer un camino inverso. Ninguno de los dos encarna cabalmente los significados asociados a ninguno de los dos ámbitos, sino que se configuran como personajes híbridos, mestizos. En tercer término, el personaje ausente de Conchi-la madre de Paco-también puede integrarse en este grupo, aunque sólo conocemos su historia de forma fragmentaria, y en retrospectiva. Analizaremos ahora las estrategias discursivas a través de las que Marsé delinea a estos personajes.

La principal voz narradora en la novela es la de Paco, hijo de la catalana Conchi Claramunt y un cordobés. Paco vive su situación de mestizo con angustia, y suele referirse a su imposibilidad de habitar plenamente ni el espacio de lo Otro, ni el de lo catalán. Es extranjero en la casa de los Claramunt, aunque bien recibido e incluido en la mesa familiar, pero tampoco posee cabalmente las características asignadas a lo migrante.

Nacido en Madrid, casi a mitad de camino entre Barcelona y Sevilla, Paco condensa características de los dos espacios:

Mis ojos eran la admiración de los Claramunt (reconocían en ese azul pálido la marca de la familia), pero no el pelo, negra pesadilla gitana, y mucho menos mi nombre: Paco Bodegas. Nombre capaz de todas las vilezas. Horrendo nombre y horrendo apellido que no tardaron en ser misericordiosamente catalanizados, primero con timidez (de Paco pasó a Paquitu) y después con decisión, hasta ser brutalmente, radicalmente borrado del léxico familiar. La ceremonia del rebautizo, en la que ofició la poderosa voz de tío Luis, tuvo lugar una tarde soleada mientras yo y mis primas jugábamos en el jardín y la familia estaba reunida en el salón: alto, autoritario, investido de extraños poderes, tío Luis se asomó a la ventana y me llamó en tono atronador: "Francesc! Les nenes no es toquen!" Desde esa tarde, toda la familia, excepto Montse, que siempre dio pruebas de sensatez, me llamó Francesc, y durante mucho tiempo tal nombre se me antojó el justo calificativo que merecía mi flagrante obscenidad, algo que de alguna manera me mostraba al mundo con la tierna porfía de mis manos en la cálida y sedosa entrepierna de mis primas. ¡Ah, comulgante, comulgante! Tiempo después se nos permitió a mis primas y a mí ir a patinar al Club Skating [...] y yo, un pelele sobre patines, un espantapájaros sentimental henchido de algo que me parecía amor, cortaba el viento musical y jadeaba ansioso, con la lengua fuera, tras las trémulas nalgas de la prima Nuria... (54-55) 
La cita pone de manifiesto el carácter híbrido de Paco. La primera oración contrasta dos significados ya revisados en el capítulo anterior asignados, respectivamente, al espacio de lo catalán y de lo inmigrante. Paco tiene ojos claros (de un azul "pálido”), pero su pelo es negro. A través del coordinante adversativo "pero", se contrastan no solamente los significados claro/oscuro, sino también los juicios que esos significados generan en el espacio de lo catalán. Así, por un lado, los ojos azules son percibidos con "admiración", como "marca de familia", mientras que el pelo se define a través del sintagma nominal "negra pesadilla gitana". Nuevamente, se observa en este punto la condensación que el dispositivo interpretador del mundo afincado en los términos Propio/Otro hace de la diversidad, igualando cualquier otredad: gitano o murciano, da lo mismo.

La simultaneidad de significados que Paco encarna físicamente no se manifiesta solamente en sus rasgos, sino también en sus movimientos: "Yo no bailaba mal, sobre todo de cintura para arriba (un smoking envarado y varonil evolucionando con la fría elegancia de una percha), pero me traicionaba el loco juego de piernas, una tendencia plebeya a la floritura y a la espuela" (225). La mitad superior de su cuerpo se asocia a la elegancia y la mesura, mientras que sus piernas se definen a partir de tres significados opuestos a los primeros: la locura, lo plebeyo y el cante andaluz (referido en la "floritura" y la "espuela").

Debido al hecho de que Paco es catalán por línea materna y no lleva su apellido, su nombre y apellido lo inscriben en el espacio de lo Otro. El recurso de la repetición del adjetivo "horrendo", para formar dos sintagmas nominales coordinados genera un efecto de intensificación del término, que según la RAE significa "que causa horror". El nombre y apellido de Paco horrorizan porque se configuran como una de las marcas visibles de la transgresión llevada a cabo por su madre. ${ }^{62}$ Su nombre recupera otro significado ya examinado: al afincarse en la legalidad diversa de lo Otro, es peligroso, “capaz de todas las vilezas”. La

\footnotetext{
${ }^{62}$ Nuevamente, en esto se ve la mirada estereotípica de género: la culpa de la transgresión es de la mujer.
} 
importancia del nombre de Paco es tal que es el único personaje al que la crítica en general denomina con nombre y apellido, mientras que Manuel, Nuria o Montse son referidos solamente por sus nombres de pila.

La progresiva transformación del nombre de Paco exhibe una de las formas a través de las cuales lo Propio se enfrenta a lo Otro, lo que evoca el referido trabajo de Levi Strauss sobre las estrategias antropoémica y antropofágica. La "misericordiosa catalanización" del nombre de Paco despliega la estrategia asimilativa, en tanto el líder del grupo familiar asume también el rol de renombrar, digiriendo el nombre foráneo, aniquilando su diferencia, y convirtiéndolo en un producto familiar. El despliegue, a nivel textual, de un campo semántico vinculado al espacio religioso duplica esta asimilación: así, el "hijo del pecado" (52) es "rebautizado", en una "ceremonia" "oficiada" por el tío Luis, quien "investido de extraños poderes" dirige el ritual civilizatorio, catalaniza el nombre de Paco en un "tono atronador" con su "voz poderosa". Los adverbios muestran la violencia en ese proceso ritual ("brutalmente", "radicalmente"), que luego, a través del vocativo "comulgante" se encuadra dentro de la religión católica, estrechamente vinculada, según veremos, al espacio de lo Propio. El nuevo nombre, sin embargo, es percibido por Paco como un castigo justo.

El motivo por el que Paco cree en la razonabilidad de su sanción recupera el tema de la hipersexualización del migrante. El adjetivo "flagrante", seleccionado para calificar la obscenidad de Paco significa, según la RAE, tanto "ardiente o resplandeciente como fuego o llama" como "de tal evidencia que no necesita pruebas". Así, la obscenidad de lo inmigrante, encarnada en el personaje de Paco, se textualiza doblemente como abrasadora e inevitable. La sexualización de este personaje se textualiza, también, a partir de la hibridez. Sobre el final de la cita, se concentran, por un lado, términos vinculados a la urgencia sexual (“jadeaba", "ansioso", "trémulas nalgas") y por el otro, sustantivos que consolidan un significado de inocuidad y de inocencia (“espantapájaros”, "pelele”). 
El personaje de Paco ocupa también un lugar difuso a nivel social. Articula, por un lado, el significado de la exclusión, característico de lo Otro, en tanto no posee los bienes materiales de sus primas. Se considera, de hecho, "un provinciano introvertido, resentido y acharnegado" (57), y hace referencia a un "cierto sentimiento de exclusión que había de crecer y devorarme" (55-56). Sin embargo, es invitado a la casa familiar - espacio que le está vedado a Manolo-y puede jugar con ellas durante su infancia:

Un rumor de sedas estrujándome, manos ensortijadas y encajes, un enjambre de tías me besuqueaba y convocaba en torno a mi cabeza rizada, escandalosamente cordobesa, visiones concupiscentes de mamá: "Criatura innocent...”. "Macu, sembla un Nen Jesús de Praga." "I la Conxi, na fent, la boixa..." "Ves ell qué sap, pobret..." Con todo, aquélla fue la época más feliz de mi vida. Los domingos bogaba entusiasmado y jadeante hacia la isla de mis primas: jardín untado con la miel amarilla de un sol que jamás he vuelto a gozar, con sus bancos de mosaico azul y blanco y su velador de piedra, el estanque y los peces rojos, los setos recortados en forma de bolas y arcos triunfales y los mudos personajillos de terracota [...]. (54)

La cita pone de manifiesto estas dos características. Por un lado, muestra la integración de Paco a la familia Claramunt, cuya riqueza material se textualiza a través de metonimias como "rumor de sedas" que configuran el retrato de las tías. La indiferenciación de este grupo, sólo referido como "un enjambre”, comprueba una priorización de la riqueza económica—tres veces referida en la metonimia — frente a la no individuación de las personas que la poseen. Los verbos de la primera sección se vinculan con el afecto, aunque exagerado y caricaturizado desde la mirada del narrador niño. Sin embargo, Paco ocupa en la cita la posición del objeto, consistente con su lugar subordinado en la familia. Además, se reitera la referencia a la marca de Otredad en su pelo. A pesar de que este primer fragmento concentra los significados asociados a lo catalán en Paco, su textualización-que termina en la construcción adverbial adversativa "con todo"- es la menos positiva del fragmento. 
La segunda parte concentra la mayor nostalgia, a la vez que los significados asociados a la exclusión. Se inicia con la cláusula de predicativo "aquella fue la época más feliz de mi vida". Sin embargo, a partir de esta cláusula, Paco describe la riqueza de sus primas, en la que sólo es incluido "los domingos". Denomina a la casa de los Claramunt "la isla de mis primas", dando cuenta de su inaccesibilidad. Una vez expresada la imposibilidad de Paco de poseer algo de aquello, se procede a una enumeración que consolida la descripción de un espacio idílico y bucólico al que es invitado, pero no puede tener. Abigail Lee observa, de hecho, que Paco se presenta simultáneamente como un comprensivo desvalido social y un admirable sobreviviente a un medio ambiente hostil ("La oscura” 365).

Su posición de invitado se repite varios años después, cuando regresa a Barcelona y comienza a trabajar en la fábrica de los Claramunt. Por un lado, la familia intercede para facilitarle un empleo; por el otro, se le ofrece un empleo no calificado, sin perspectivas de crecimiento laboral. Una vez instalado en la fábrica, transcurren dos semanas hasta que es invitado a la casa: "Llevo dos semanas trabajando en la fábrica de la calle Escorial y por fin esta tarde tío Luis me manda llamar a su despacho para preguntarme si estoy contento con el trabajo [...] y para invitarme a cenar en su casa" (63). En la construcción adverbial "por fin" se advierte el deseo de inclusión. Su posición subordinada se comprueba nuevamente en el rol de objeto directo, mientras que la jerarquía del tío Luis en la perífrasis verbal "manda llamar".

Su condición de invitado se continúa en 1970. Sus características físicas denotan su distancia con respecto a lo catalán, aunque también existe una conciencia irónica sobre sus bordes. Paco sabe que su apariencia es de sureño, pero sabe también-luego de haber vivido lejos de la península ibérica—que estos límites son convencionales: "Y un trago que me ha servido Purita con una mirada absolutamente reprobatoria. Por cierto, convendría comunicar al servicio que soy tu primo y que gozo de la hospitalidad y la plena confianza del señor de la fortaleza. Tengo la impresión de que me toman por un chulito de las Ramblas contratado 
provisionalmente por la señora" (144). Se pone de manifiesto la ambivalencia del personaje: por un lado, se distancia del servicio y sugiere qué información se le debe brindar. Esta información se presenta con dos verbos que reafirman su origen catalán (“soy tu primo", "gozo de la confianza"). Sin embargo, Paco también enuncia su impresión de los juicios que genera en los demás, su apariencia-intensificada con el diminutivo-lo inscribe en la Otredad. También es consciente del contraste entre su aspecto ("chulito") y el de Nuria y Salvador ("la señora”, “el señor”).

A veces, Paco se incluye en la familia Claramunt: “[N]osotros los Claramunt (permitan que me incluya, me embarga la emoción), aquí arropados en esta torre” (193). Sin embargo, sabe que ocupa ese espacio liminal, de aceptación a medias: "[L]a oía sentado en la cama y cabizbajo y era como en viejos tiempos no vividos, sentirme instalado en la añeja tradición veraniega de los Claramunt en Sitges, era como asomarme a lo que no fui, a los gestos perdidos de otra infancia, pero sólo duró un instante" (216). En Paco se observa una zona de potencialidad, visible en la negación de los verbos relacionados con la biografía ("no vividos", "no fui") y en la construcción nominal "otra infancia”. En Manuel no existe posibilidad alguna de ser integrado, pero en Paco esa potencialidad (la de haber vivido otra vida) está latente, y se hace expresa una sensación, la de estar instalado en la casa familiar de veraneo.

Otras veces, Paco se inscribe cabalmente en el espacio de lo Otro. En un momento de la narración, se observan sus inútiles esfuerzos por asumir la represión característica de la burguesía: "[S]us nervios se relajan y siente de pronto la insólita necesidad de liberar una carcajada — algo de raíz cascabelera, algo que siempre esperó dormido allá en su entraña más cordobesa y salerosa y que desde ese día le exigirá modificar su comportamiento en esta casa..." (95). En la casa de los Claramunt, debe reprimirse y controlar su media naturaleza “cordobesa y salerosa”. También, de niño, su tía justifica su mal comportamiento y afirma que se debe a "l'herència del trabucaire" (la herencia del bandolero, en catalán). Paco sabe de este 
juicio, y sabe también que muchas veces es un juicio erróneo. De hecho, sabe que sus tíos están convencidos de que su gusto por los buenos vinos "era herencia nefasta del cordobés", aunque en realidad se lo "había inculcado y educado Conchi, una Claramunt" (68).

No solamente Paco es un personaje híbrido, sino que Montse, por otra parte, también se sitúa en un punto intermedio entre lo catalán y lo foráneo. En primer lugar, Montse se textualiza en radical contraste con Nuria, quien asume una identidad catalana por antonomasia. Paco, de hecho, le pregunta a su prima: “-¿Cómo pueden dos hermanas -dije-educadas en los mismos sagrados preceptos, ser tan distintas?" (24). Si el retrato de Nuria es el de una mujer erotizada, siempre atractiva - incluso cuando es muy joven-y con cierta malicia, Montse se textualiza como una mujer fea, asexuada ${ }^{63}$ y extremadamente buena y solidaria. De hecho, la primera descripción de Montse en la novela ni siquiera hace referencia a sus características físicas:

Con una sonrisa limpia asaltaba por los pasillos a todo el personal de administración, zalamera y terca en sus triviales pretensiones, una curiosa mezcla de niña mimada y de viejecita cascarrabias, hasta que conseguía hacerse con unos duros para sus niños pobres del Guinardó y del Carmelo. Muchos procuraban evitarla, a menudo de forma grosera; cierto que su nerviosa locuacidad y su alegría podían llegar a ser mareantes, pero aquello que más le criticaban, la pesada obsequiosidad con que se acercaba a la gente y la envolvía, no era sino el justo excedente vital con que a menudo se veía obligada a suplir la mal disimulada indiferencia, la pereza verbal y la sequedad de corazón de los que la tratábamos: con ella nadie hacía el menor esfuerzo por ser agradable, y ni siquiera éramos capaces de disimularlo. Aparentemente siempre ocupada, sin tiempo ni ganas de pensar en sí misma, era una esencia volátil, asexuada, sin deseos ni complejos. Y lo que primero llamaba la atención era su voz: hermosa voz de constipada crónica que escondía un eco húmedo, una doblez afectuosa. $(64-65)$

Lo primero acerca de Montse que observa el lector es su sonrisa y su voz. Su construcción como personaje deserotizado, opuesto a Nuria, se sugiere en varios puntos de la

${ }^{63} \mathrm{Al}$ menos al principio; nos referiremos luego a su lenta transformación. 
descripción, vinculados a diversas anulaciones. En primer término, se dice que es una mezcla de niña y anciana, y, por lo tanto, se la suprime como mujer, plausible de desear y ser deseada. En segundo lugar, Montse es una “esencia volátil”, lo que la anula como cuerpo físico, material. En tercer lugar, en el adjetivo "asexuada", intensificado por la construcción preposicional "sin deseos ni complejos" se niega rotundamente cualquier posibilidad de erotización. La represión sexual se hace aún más fuerte con la adjetivación "constipada crónica" vinculada a su voz. El bloqueo de lo sexual en Montse es tan marcado que el primer registro en la novela (anterior a su retrato) la muestra totalmente replegada sobre sí, con "los brazos cruzados, las rodillas juntas" (18). En la falta de corporeidad de Montse, Sherzer registra la intención de Marsé de subrayar su aspecto más importante, que es "su valor espiritual y su persona interior" (Juan Marsé 124).

Sin embargo, la deserotización del personaje no la convierte en un sujeto pasivo. Se la presenta activa, comprometida con la causa solidaria, a través de verbos que implican una lucha de su parte ("asaltaba", "conseguía”, etc.) y una resistencia a esa lucha, por parte de la sociedad ("procuraban evitarla", "criticaban"). En el aspecto imperfecto de esos verbos se sugiere una lucha y una resistencia que se extienden en el tiempo. Hay dos campos semánticos enfrentados que exhiben sus intenciones (“zalamera", "terca") y la resistencia de aquellos de quienes ella esperaba ayuda ("forma grosera", "indiferencia”). En la selección de los verbos, en su modo gramatical, y en la contraposición de estos campos semánticos se advierte una descolocación en la forma de Montse de habitar el espacio de lo Propio. Su solidaridad se contrapone a la hipocresía religiosa de la burguesía catalana, como veremos luego. Por otro lado, también en este ímpetu se distancia de su hermana; Paco dice de Nuria que "nunca sería animosa y decidida como su hermana" (51). La distancia entre Montse y Nuria es registrada también por Garzo, quien afirma: “[M]ientras que Nuria es la encarnación de cierta femineidad suntuosa, llena de 
volátiles promesas, Montse renuncia a ese fondo de almenas y dragones para transformarse, tal vez sin pretenderlo, en una muchacha real" (253).

Hemos afirmado que Montse realiza un camino inverso al de Paco: se desplaza de la casona familiar hacia el cuarto de pensión. Este tránsito también es visible en una progresiva corporización del personaje, diversa de la de Nuria. Nuria es un sujeto erotizado, pero nunca deja su lugar de privilegio. La progresiva corporización de Montse es más compleja; el lector observa el proceso de maduración en el que la "esencia volátil” se convierte en una mujer. En este proceso Sherzer considera que existe una predialéctica, una tensión entre "una Montse reprimida y una Montse en pugna por autorrealizarse" (Juan Marsé 127).

En el momento de La oscura historia en el que la familia comienza a inquietarse por la relación entre Montse y Manolo, se observa una segunda etapa en este proceso:

[L]as fuerzas abandonan ese cuerpo severamente vestido-blusa color violeta abrochada hasta el cuello, jersey azul, larguísima falda plisada, a cuadros rojos y verdes, muy holgada. Con los brazos cruzados, pasea nerviosamente [...] abrazada a su vientre como si le doliera o tuviera frío [...]. [P]ermanece callada mirando el suelo, y luego vuelve hacia él su frente vencida, tersa, de una hermosura lumínica [...]. Según los cánones actuales, es fea; el pelo negro partido en dos sobre la frente [...] es como un melancólico casco que oculta las orejas y le da una forma triangular a la frente de nácar [...]. Tiene en el rostro esa gravidez de las tuberculosas, esa palpitación serena bajo la piel transparente de la frente y de los pómulos, una armonía de expresión basada [...] en cierta luz de la piel que trasciende desde quién sabe qué rincón abrasado y amable del alma.

Ahora mira a su primo como si no le viera, y, con esa ignorancia desafectada que tiene de su físico, deja una mano yerta sobre el pecho izquierdo, rozando distraídamente la tela con la uña. Diríase que trata a sus pechos de una manera torpísima, o que los lleva sin saberlo: te roza con ellos al pasar, se los chafa sin darse cuenta, se los toca y al parecer los siente como si fuesen molestas protuberancias cuya utilidad no acabara de entender: no tiene aún conciencia de su cuerpo. (97-98)

Se observa una progresiva corporización del personaje, en los sustantivos "cuerpo" y "físico". Se evidencia ya una referencia a su vestimenta, aunque ésta oculta su figura: la blusa 
está "abrochada hasta el cuello", la falda es "larguísima" y "muy holgada". Nuevamente, se hace referencia a la postura de repliegue sobre sí misma. La deserotización del personaje se comprueba también en la afirmación "es fea" y en la comparación con "las tuberculosas". 64

Sin embargo, se mencionan varias partes de su cuerpo, a pesar de que las descripciones no sean siempre positivas. Se menciona, por ejemplo, el "vientre", al que se lo adjetiva a través de dos construcciones comparativas asociadas a la sensación física. Aunque se compara su peinado con un "melancólico casco", Paco también registra cierta belleza, prefigurada en el campo semántico que forman palabras como "tersa" o "hermosura". En la blancura de su piel se comprueba su carácter de Propia.

El último párrafo condensa el carácter transitorio de esta etapa en su proceso de corporización: si bien ya—para el narrador y para el lector-Montse tiene cuerpo, aún "no tiene conciencia" de eso. La falta de consciencia de Montse sobre su cuerpo se despliega a través de varias construcciones que repiten esa idea: “como si no lo viera", "ignorancia desafectada que tiene de su físico”, entre otras. En esa repetición se observa el contraste entre la consciencia que ya existe en Paco-y en el lector—de que Montse es una mujer y en su propia ignorancia. La anulación de su cuerpo corre ahora solamente por cuenta de ella, ya no es textual.

La tercera etapa del proceso de transformación de Montse la configura ya como una mujer, aunque en un punto crítico de aceptación de esos cambios:

$[\mathrm{N}]$ o se ha dado cuenta del estado de su camisón, completamente empapado, pegado al cuerpo como una piel y subido hasta las ingles. No sólo eso: sus muslos, de una palidez rosada y marmórea, relucientes de sudor, prolongan [...] un suave entrechocar [...] que va configurando poco a poco, al ir escurriéndose ella entre tus brazos, la torpe posición de un abrazo a tu cintura. Se va acurrucando, deslizando. Los temblorosos brazos ciñen tus riñones, y ahora, fijos en el vacío sus ojos vencidos y tristes, la sangre golpeando en sus manos

\footnotetext{
${ }^{64}$ En esta referencia se observa la relación con un modelo modernista de belleza femenina, de fuerte raigambre en la tradición literaria española.
} 
con urgencia, adquiere de pronto conciencia de su desnudez, o mejor dicho, de tu presencia ante su desnudez: una oleada de vergüenza o de lástima de sí misma la deja sin fuerzas, enternecida, miserable, sometida totalmente al capricho de su postura [...]. Tiembla y gime. "No llores, prima, no llores", balbuceas torpemente. Al cabo, como temías, al resbalar aún más su arrebolada mejillaluego su boca — sobre la tela del pijama, roza apaciblemente tu sexo. Un instante solamente [...] - por otra parte, ignoras todavía el grado de intimidad que han alcanzado sus visitas al presidiario en el cuartucho de una pensión de la Barceloneta-. (122-23)

En esta etapa, la textualización del cuerpo de Montse visibiliza referencias a partes del cuerpo más privadas (“ingles", "muslos”) y hace manifiesto un cambio en su postura. Ya no se la describe replegada sobre sí misma, sino que se abre a abrazar y a ser abrazada. En los gerundios se construye una idea de continuidad, cuya intensidad crece a medida que se desarrollan las acciones. Esta idea de acción en proceso se interrumpe con la construcción adverbial "de pronto", que da lugar a un momento epifánico: Montse adquiere conciencia de su cuerpo, ya sea a través de su propia mirada o a través de la mirada del otro. Iris Young afirma que, debido al sistema social patriarcal, la mujer habita su cuerpo no solamente como sujeto, sino también como objeto. Sostiene que el sujeto femenino interioriza la mirada objetivante patriarcal, lo que trae aparejado una determinada manera de situarse físicamente en los diversos espacios que transita. La mirada del otro-ya sea real o interiorizada-opera visibilizando una toma de consciencia sobre el propio cuerpo, desde una mirada objetivizante (154). Una vez que Montse adquiere esta conciencia de sí, se textualizan dos campos semánticos opuestos, uno vinculado a la represión sexual catalana, definida a partir de términos que describen sensaciones ("vergüenza", "lástima") y otro, vinculado a la sexualización de lo sureño, a partir de verbos como "tiembla" o "gime".

Por otra parte, esta es la primera referencia a la palabra "sexo" vinculada a Montse en toda la novela. La cláusula entre guiones con la que se cierra la cita no solamente plantea la duda de Paco sobre la virginidad de Montse. Es permeable, además, a una interpretación en 
clave confirmatoria, en tanto el objeto de "ignoras"-potenciado por el circunstancial "todavía" — no se continúa con una cláusula condicional iniciada por "si" o por un pronombre interrogativo (“cuál”), sino que se presenta como una construcción sustantiva. El "todavía”, entonces, alude a la ignorancia de Paco sobre un hecho, no al hecho mismo. Finalmente, en el campo semántico vinculado a la tristeza, desplegado en toda la extensión de la cita, se ve el carácter de crisis con el que es vivido el proceso.

La cuarta etapa del proceso de corporización de Montse implica la percepción de ese proceso por parte de los demás:

Se me ocurrió entonces hablarle de aquel cambio físico que lentamente se operó en su hermana, precisando que no era exactamente que se hubiese alterado su sencillez en el vestir, su natural recato, sino que algo, una dejadez, una silenciosa materia húmeda que la envolvía como un vapor sexual, empezó a ennoblecer su tímida figura a medida que la incontinencia licuaba en su interior. Hablé de ciertos días en que su cuerpo parecía alcanzar una vida independiente de sus activos sentimientos, y de cómo a partir de entonces su figura se concretó, dejó de ser aquella mareante gama de gestos inconscientes y a menudo desequilibrados, adquirió peso y volumen, gravidez, el sugestivo imperio de la contención. Eso, que en otras mujeres más superficiales habría reducido su atractivo, en ella floreció en una misteriosa cualidad sensual. (215)

El reconocimiento de esos cambios por parte de los demás se hace manifiesto a nivel textual en un extenso campo semántico vinculado a la sustancia ("materia", "figura", etc.), opuesto a uno referido a la esencia precedido por la perífrasis “dejó de ser”. La diseminación de palabras vinculadas a la humedad ("húmeda", "vapor", "licuaba"), sumada al hecho de que finalmente en este fragmento Montse se integra en el colectivo "otras mujeres" implica una nueva etapa en la maduración sexual del personaje. Hemos revisado, entonces, el camino que recorre Montse de lo Propio (represión sexual, anulación de su cuerpo y de su femineidad) a lo Otro (corporización, sexualización). Este camino se puede entender como un "cambio de piel”, 
que efectivamente sucede cuando Montse finalmente huye de su casa y se instala en la pensión de Manuel:

Ya no era ella y sin embargo seguía siendo ella, ratificada súbitamente bajo otra luz pero intacta y robustecida su discreción y su salud moral, ensimismada. Por la mañana, arrodillada sobre la cama revuelta, la cabeza despeinada y ladeada, Montse se entretiene arrancando cuidadosamente la piel de seda de sus hombros quemados por el sol de las playas libres. Lo hace despacio, soñolienta, replegada y absorta en sí misma. Con el vaso de nescafé en la mano, de pie en el balcón, desnudo el torso, él bromea diciéndole que ya ha cambiado totalmente la piel, como las serpientes, dejándola tras de sí con todo lo demás... Y Montse se sonríe irguiéndose sobre las rodillas, desperezándose con los brazos en alto, estatuaria en medio de sus delicados, finísimos, lastimados despojos de seda marca Claramunt. (244)

La etapa final de este proceso involucra una transformación, una síntesis. La referencia directa, a través del recurso de la comparación con "las serpientes", a su abandono de la represión burguesa, también se observa a nivel físico. Aquella blancura de su piel ahora se muestra en sus hombros "quemados por el sol de las playas libres". La comparación con las serpientes también se abre a una interpretación en clave (anti)religiosa: Montse ha dejado la hipocresía del catolicismo nacionalista catalán para experimentar un amor sin prejuicios de clase. A pesar de que ha abandonado su espacio de origen, no logra aún integrarse en la Otredad, y esta situación intermedia se observa en la textualización de lo fino (“delicados”, "finísimos", "seda") como un "despojo" "lastimado".

Por otra parte, la textualización de Montse como sujeto híbrido también se comprueba en el hecho de que transita los dos espacios. Habita la casa de sus padres, en la zona altoburguesa de Gracia, habla catalán, ha recibido una educación institucionalizada y ocupa, a nivel social, un espacio dominante. Sin embargo, su compromiso genuino con las Visitadoras de la Caridad la lleva a caminar sin prejuicio los espacios habitados por la inmigración del sur. Nos referiremos en breve a la configuración de los espacios, pero es relevante notar que 
Montse, nacida en uno, habita—mucho antes de mudarse a la pensión—, ambos. Manuel, de hecho, dice de Montse: “Conoce la vida, ha visto más miseria y más injusticia que su señora madre, con perdón, no verá en toda su vida. Pasa más tiempo en los suburbios y en las barracas que en su casa" (202).

Finalmente, cabe referir al personaje de Conchi. Conocemos su historia a través de los recuerdos de Paco: Conchi logra perpetrar la transgresión que queda trunca en Montse y da a luz al hijo mestizo. Realiza físicamente el camino de lo catalán a lo sureño, y deja Cataluña para convertirse en migrante dentro de España. El paralelismo con la historia de Montse es evidente, Paco informa: "No, es inútil, nada en común. Pero mi enternecedora colección Conchita, siempre que la repaso, me lleva a esta conclusión: hasta hoy no he conseguido aislar ni una sola imagen donde la prima Montse no esté presente de alguna manera" (61).

La Otredad y lo Propio se asocian a determinados espacios. La casona de los Claramunt, en el barrio de Gracia, antes de la tragedia, representa algunas de las características de lo catalán:

Un gran sauce llorón, lilas, mimosas, rosales, hortensias, dispuesto todo en suaves y redondeados montículos de tierra parda, parterres como islotes cuya geométrica disposición formaba un delicioso laberinto de senderillos cubiertos de grava. Y presidiendo aquel archipiélago feliz, la vieja torre con sus dominicales y solemnes resonancias de órgano, el chalet de persianas verdes, airoso y sólido a la vez, con su inclinada techumbre de pizarra que recogía los arreboles del crepúsculo y su esbelta torre en la esquina, rematada por un cucurucho con pararrayos. (54)

El lirismo con el que se describe la casa, sumado a la abundancia de adjetivos vinculados a la belleza y a la elegancia ("suaves y redondeados", "solemnes", etc.) confirman la vinculación con la delicadeza. La abundancia de especies plantadas en el jardín replica asimismo la abundancia material de los dueños de casa, recuperando la asociación con la riqueza material. Además, en el sintagma "dominicales y solemnes resonancias de órgano" se ratifica la 
articulación entre lo autóctono y la religión católica. Esta imagen auditiva se encuentra en diálogo, además, con la comparación entre los Claramunt y el Orfeo coral catalán. Por otra parte, se corrobora nuevamente la dificultad de acceso a lo catalán para Paco, que es quien narra, textualizado nuevamente a través de la idea de la isla.

En 1970, luego del suicidio de Montse, el viejo chalet de Gracia concentrará cierto significado negativo asociado a lo Propio, el de la hipocresía:

El verano pasado, el viejo chalet de tía Isabel fue condenado al derribo. Cercado por rugientes excavadoras y piquetas, aquel jardín que el desnivel de la calle siempre le mostró en un prestigioso equilibrio sobre la avenida Virgen de Montserrat, al ser ésta ampliada quedó repentinamente como un balcón vetusto y fantasmal colgado en el vacío, derramando un pasado de aromas pútridos y anticuados ornamentos florales, soltando tierra y residuos de agua sucia por las heridas de sus flancos. Grandes montones de tierra rojiza se acumulaban alrededor de la señorial torre, que aún no había sido tocada: seguía en pie su arrogante silueta, su apariencia feliz y ejemplar. Pero dentro, en una de sus vacías estancias de altísimo techo, sólo quedaba una gran cama revuelta, una raqueta de tenis agujereada y libros apilados en el suelo. Fachada, he aquí lo único que les quedaba a los Claramunt. (5)

El fragmento revela dos campos semánticos enfrentados, el de la suntuosidad y la elegancia (“prestigioso equilibrio", "señorial”, etc.) y el de la ruina ("vetusto y fantasmal”, "pútridos”, entre otros). Estos dos campos muestran la decadencia de la familia, subrayada a nivel textual por la abundancia de estructuras pasivas, que marcan lo inevitable de esa decadencia. De las escasas estructuras en voz activa, todas construidas alrededor del núcleo verbal "quedar", tres se vinculan también con ese declive. La primera se presenta la forma conjugada "quedó", que implica una permanencia, y cuyo sentido de inevitabilidad se refuerza con el aspecto perfectivo. La comparación siguiente configura un campo semántico que puede asociarse con un cementerio ("fantasmal”, "pútridos", "anticuados ornamentos florales”, "tierra”), lo que definitivamente potencia la idea de inexorabilidad. La segunda estructura activa ("quedaba en pie") y la tercera ("quedaba una gran cama revuelta") presentan los dos términos que se 
resumen en la palabra "fachada". Esta palabra, también, concentra un significado de apariencia, de hipocresía que se vincula con el espacio de lo catalán.

La novela también representa espacios que se configuran como exclusivos de la población migrante. Al salir de la cárcel, Manuel se instala en la Pensión Gloria, cerca del Mercado del Borne, en el casco antiguo de la ciudad:

Desfilaba tras su perfil una pared desconchada y mugrienta, oscuros portales y angostas agencias de transporte, eran calles estrechas con tabernas de vidrieras pintarrajeadas con letreros tras los que se apretaba una luz humilde y blanda como algodón, caras borrosas, reflejos y sombras como larvas, todo difícilmente relacionable con mi prima; [...] absurdo, nada en estas negras calles empedradas tenía que ver con la señorita Claramunt excepto, quizá, quién lo hubiera dicho, este hermoso ejemplar de rufián domesticado y evangelizado que la seguía como un niño rumiando el último castigo materno. Fue corto el trayecto; callejones mal alumbrados y plaza del Mercado, donde a esta hora los camiones empezaban a descargar cajas de fruta y verduras en medio de luces oscilantes, carretillas metálicas, motores gimiendo y órdenes a grito pelado. Luego el letrero verde que decía "Pensión Gloria", sujeto a los hierros del balcón, y debajo el amplio zaguán que olía a moho y donde las palabras resonaban desagradablemente, se volvían contra uno: me había enredado en una confusa explicación sobre el trabajo en el almacén, supuse que a él le interesaría. La oscura escalera con ventanas sobre el patio negro, la puerta que seguía abierta, la salita desierta con dos sobadas butacas que soltaban espuma por todos lados. (198)

El locus de lo sureño se caracteriza por la escasez y lo vulgar. La idea de escasez se consolida, en primer lugar, a través de un campo semántico vinculado a la pobreza y a la ruina. En segundo lugar, la idea de carencia se asocia también a la falta de espacio, frente a los amplios jardines, aquí se advierten "angostas agencias de transporte", y "calles estrechas". En tercer lugar, la idea de escasez se asocia con la oscuridad; la luz no es suficiente, lo que reitera el contraste con los espacios bucólicos y soleados de lo Propio catalán. Los carteles recuperan el prejuicio afincado en la represión sexual burguesa: las vidrieras están "pintarrajeadas”. La idea de sordidez se refuerza con una profusión de imágenes auditivas desagradables. Las personas que habitan ese espacio se articulan con la idea de oscuridad. En la comparación, y en la 
metonimia (son "caras", "sombras", "reflejos") se deshumaniza a los habitantes de la Otredad, que se camuflan con su contexto. En Piel negra, máscaras blancas, Fanon observa un proceso similar de deshumanización para el caso de la negritud en las Antillas: "El negro no tiene resistencia ontológica frente a los ojos del blanco. Los negros, de un día para el otro, han tenido dos sistemas de referencia en relación a los cuales han debido situarse. Su metafísica o, por decirlo de manera menos pretenciosa, sus costumbres y las instancias a las que éstas remitían, fueron abolidas porque se contradecían con una civilización que [...] se les imponía" (111-12). Lo sureño se textualiza así por oposición negativa a la catalanidad, siguiendo el pensamiento binario.

La pertenencia de Manuel al espacio inmigrante se corrobora en que no desentona con el escenario. Sin embargo, se salva de la sordidez, y se textualiza con una ternura irónica que comprueba la preferencia del autor por los perdedores. Se recupera así la característica vinculada con su atractivo físico-“hermoso ejemplar"- -y se procede, luego a dos comparaciones sucesivas que lo rescatan del pesimismo con el que se describe su espacio. Es, en primer lugar, un "rufián domesticado y evangelizado": el oxímoron vacía de sentido la carga negativa de la palabra "rufián", que además pierde su potencia con los dos participios, estructurantes de una idea de pasividad. Esta pasividad se recupera en la comparación "como un niño rumiando el último castigo materno". La asimetría social entre Montse y Manolo se replica en otra idea jerárquica, la de la madre y el niño y, en cierta medida, el lugar inferior que ocupa Manolo se vincula también con una cierta animalización del personaje ("hermoso ejemplar" o "rumiando" estructuran la idea de un animal inofensivo). Así como Manuel no contrasta con este espacio, Montse, nacida en el seno de una familia catalana burguesa, sí que es "difícilmente relacionable" con ese lugar. Y en su recorrido por los espacios de los migrantes, Montse sigue conservado su jerarquía, lidera la caminata y es "seguida" por el muchacho. 
La Otredad de Manuel se advierte también en la playa, donde a los ojos de Montse también se distingue de los demás migrantes. Los espacios balnearios frecuentados por los catalanes se localizan fuera de la ciudad de Barcelona: los Claramunt veranean en Sitges, los Serrat lo hacían en Blanes. Los inmigrantes, por otra parte, ocupan la Barceloneta, textualizada como desagradable:

Es un mundo chillón y superpoblado que se cuece al sol. Son los detritos industriales del emprendedor seny condal, la servidumbre tranviaria y fabril y el peonaje foráneo que impone su fea desnudez en una reducida zona libre de sucia arena y turbias olas donde flotan residuos de comidas y de coitos degradados, un mundo abigarrado y violento y feísimo que ella había rehuido hasta hoy y dentro del cual no es fácil mantenerse limpio ni guardar una postura digna durante mucho rato.

Imposible no embrutecerse aquí-pensaría Montse - , hay una amenaza de contagio. Y, sin embargo, ciertos seres maravillosamente dotados [...] consiguen la inmunidad: sordos al griterío de la playa, habituados a la promiscuidad, acomodaticios e indemnes entre las rociadas de arena pegajosa que por doquier salpican pies ajenos en sus correrías y juegos impertinentes, ellos y sus toallas se mantienen milagrosamente puros [...] en medio del apretujado caos, en espacios reducidísimos, cuerpos [...] incólumes, inmaculados.

-iTe estás durmiendo, Manuel?

Él, precisamente, es uno de estos seres dotados para vivir aquí, en este febril hormiguero. A su alrededor luchan y se revuelcan los amigos de la patrona, y el asqueroso polvillo que levantan respeta extrañamente su piel y su toalla mientras duerme. (218-19)

Nuevamente se recuperan la idea de falta de espacio ("superpoblado", "apretujado caos", etc.) y las imágenes auditivas molestas (“griterío”) en este espacio en el que la referencia a la exclusión de lo sureño por parte de lo catalán es directa: la Otredad se configura como “detritos industriales" de lo Propio ("el seny condal”). Esta metáfora encubre la crítica social al rechazo de lo catalán para con el inmigrante. La asimetría social entre el inmigrante establecido en la periferia y el catalán dominante se textualiza violentamente en el término "detritos", pero también es aludida en la idea de "peonaje" o "servidumbre". 
El espacio de lo inmigrante es el de la suciedad, idea que se construye en el texto a través de un campo semántico abundante que comprende construcciones sustantivas asquerosas e imágenes visuales desagradables. Se suma a la definición de este ámbito la idea de violencia (“luchan"). También se recupera un vocabulario erótico, que define una sexualidad en términos negativos, a partir de adjetivaciones pesimistas sobre sustantivos neutros ("fea desnudez", “coitos degradados") y a partir de sustantivos negativos ("promiscuidad").

Estas tres ideas se articulan un significado que las trasciende: el de la enfermedad. La Otredad se consolida como una enfermedad contagiosa, por lo que es "imposible no embrutecerse" al ocupar ese espacio. Porque sabemos que Marsé suele posicionarse del lado de los perdedores, y porque muchas veces hace de las clases burguesas catalanas un elemento risible, creemos que la idea de la "amenaza de contagio" es permeable a una lectura en clave irónica del prejuicio catalán sobre lo migrante. La ridiculización de la percepción de la potencialidad del peligro de lo Otro es, creemos, lo que lo lleva a titular el capítulo en el que se inserta esta cita con la frase nominal "El contagio". Cabe también la posibilidad de interpretar que, debido a que la mirada de Montse rescata a la figura de Manuel de ese contexto, la vinculación entre la idea de contagio y la de lo Otro también sea parte de sus propios prejuicios, pues hemos visto que este personaje no se inserta cabalmente en ninguna de los dos términos del binarismo.

A diferencia de Últimas tardes, La oscura historia presenta algunos espacios híbridos de intersección, que concentran significados asociados a la catalanidad y a lo sureño. Estos espacios hacen visible el carácter de constructo de la supuesta solidez de bordes que separan lo catalán de lo migrante. La parroquia en la que Montse ejerce su labor solidaria se configura como uno de estos. Es el ámbito en el que coinciden los niños migrantes, Salvador y el personaje móvil, Montserrat Claramunt: 
Por cierto que el grupo de Visitadores se componía de jóvenes obreros de casa pobre y señoritas más o menos ociosas de casa rica: la parroquia estuvo siempre incondicionalmente abierta a todos los vientos y criaturas del Señor, de modo que entre la feligresía de este barrio, vieja zona residencial devorada por la expansión de Gracia y por la foránea invasión de la posguerra que nutrió de charnegos el Guinardó y el Carmelo, ciertas piadosas catequistas casaderas y de buena familia podrían ser presa fácil de unas pocas sombras masculinas en genuflexión que frecuentan la parroquia desde su niñez y que viven en repliegues del distrito que nadie conoce [...]. (91-92)

La cita se erige a partir de dos campos semánticos contrapuestos, uno vinculado a lo catalán, aludido a partir de algunos de sus significados asociados (“casa rica", "zona residencial") y otro, que también se prefigura a partir de la recuperación de vinculaciones semánticas ya examinadas, que alude a lo charnego (“foránea invasión”, “charnegos”). La posibilidad de cruce, si bien se construye en forma irónica, se admite. En esta factibilidad de intersección de los dos mundos Marsé delimita otra zona de hibridez.

La ironía del narrador se despliega en varios frentes, a través de una ventriloquía. El narrador reproduce discursos que no le pertenecen, y en esto se genera una cierta humorada corrosiva de lo que esos discursos enuncian. En primer lugar, se apropia del discurso pastoral, y enuncia que "la parroquia estuvo siempre incondicionalmente abierta a todos los vientos y criaturas del Señor”. Sin embargo, poco después intercala el discurso xenófobo nacionalista, y lo pone en juego; se refiere a la ola inmigratoria como una "foránea invasión”. El juego entre estos dos discursos se repite más adelante, cuando denomina a las mujeres voluntarias “piadosas catequistas”, y a los varones "pocas sombras masculinas en genuflexión”.

Otro ámbito que rehúye de la dicotomía sureño/catalán es París, que, a pesar de que no figura materialmente en la novela, sí tiene relevancia al ser el lugar donde vive Paco, y donde Nuria lo visita. Paco narra: "El ABC colgado en los flancos del quiosco frente al Flore, tercer viaje, un café para ella, un Pernod todo agua para mí: se me ha presentado embutida en una pana color ceniza, pantalones y bufanda, sin maquillaje, desgreñada, libre y antifranquista. 
París nos politiza, nos poetiza y nos erotiza, a los españoles” (108). La cita no solamente pone de manifiesto el abandono que Nuria hace de sus obligaciones de clase- $-\mathrm{y}$ en este sentido, París es un espacio al margen de las dicotomías - sino el hecho de que Paco se considera (y la incluye a Nuria, y quizá a toda la sociedad, en el pronombre "nos") español. En París, los bordes entre catalanes y sureños pierden validez: los dos se aproximan al tornarse simultáneamente Otros en Francia. Se advierte así la arbitrariedad—y la relatividad—de esos bordes.

Finalmente, es relevante destacar la forma de suicidio de Montse, que se arroja desde el puente de Vallcarca. Pocos espacios hay más híbridos que un puente, a mitad de camino entre dos puntos, sin pertenecer cabalmente a ninguno. Localizado en la parte alta del distrito de Gracia, el viaducto de Vallarca cobró, a partir de los años veinte, "fama inquietante como puente de los suicidas" (Theros). La trasgresión de Montse es castigada, pero incluso su elección última exhibe su capacidad para habitar los bordes.

Uno de los significados asociados a lo autóctono en La oscura historia es el de lo religioso. En un registro irónico, se hace manifiesta la discordancia entre lo que la institución religiosa promueve y lo que lleva a cabo. Este tema concentra el tono crítico con el que Marsé retrata al nacionalismo catalán. Uno de los personajes más profundamente imbricados en este discurso es Salvador Vilella.

Salvador asume cabalmente los significados de lo catalán (el dinero, la represión sexual, la religión, la hipocresía, la lengua catalana), si bien proviene de un contexto pobre y es su ambición la que lo lleva a casarse con Nuria. Salvador no tuvo educación religiosa (contrariamente a Paco), y cuando es interpelado directamente decide cambiar de tema:

-Tú fuiste a los Salesianos, ¿no?

-Yo, sí, ¿y tú?

-¿Algo de tapas? (91) 
Sin embargo, Salvador se asume como el portavoz del nacionalismo catalanista católico, escribe publicaciones y organiza conferencias. Su adherencia a este movimiento se comprueba directamente en su actividad de conferenciante:

Seguidamente habló de cómo le absorbían ya los asuntos de la fábrica y su trabajo en la Diputación (un cargo confusamente cultural), además de la sagrada causa pro-lengua vernácula escarnecida, con sustanciosos y misteriosos intereses editoriales de Aportació Catalana, y, sobre todo, de aquella actividad que más le enorgullecía: la de conferenciante. Refiriéndose al ciclo de conferencias cuyo tema general: "Las actividades económicas y la Iglesia en el mundo moderno" [...]. (34)

El fragmento pone de manifiesto de forma sutil la alianza de tres significados, y en esto encubre una crítica política. Salvador es, al mismo tiempo, un empresario, un funcionario público y un conferenciante religioso. Al hacer coincidir estos tres significados en un personaje, Marsé sugiere la articulación entre el poder económico, el franquismo y la Iglesia. En la referencia a la lengua vernácula y a los intereses editoriales se encubre una segunda crítica al apoyo del nacionalismo catalán a la Iglesia y a la dictadura para salvaguardar sus intereses económicos. Esta crítica se recupera en otro punto del libro, en el que Paco conversa con un asistente a las conferencias de Salvador. En pleno franquismo, éste afirma que "lo verdaderamente ignominioso era no tener obispos catalanes" (47). Se advierte entonces que el discurso religioso opera muchas veces para disimular una crítica sociopolítica.

La contradicción entre apariencia y realidad que consolida la hipocresía de la burguesía catalana suele revelarse en los diálogos que Paco mantiene con Salvador, en los que aquél hace visibles las contradicciones que éste insiste en ocultar. Paco le dice:

-No deja de ser medianamente asombroso y hasta admirable -entonó gregorianamente el reverendo Vilella con clergyman, riendo -que un andaluz 
triunfe en París en tan poco tiempo y nada menos que en el cine, algo tan extraño a la naturaleza de nuestras pasiones o virtudes.

-No menos extraño -entonó el reverendo Bodegas, con sotana pero una cuarta más alto -que el hecho de que el catequista oscuramente parroquial y suburbano que fuiste tú ocupe hoy, y en menos tiempo, un cargo en la Diputación y se codee con el cardenal Acquaviva. Debe de ser una prueba del desarrollo del país. En mí no es tan raro, hay antecedentes en la familia: ya sabes que Conchi fue script. (32-3)

El campo semántico vinculado a lo religioso ("gregorianamente", "reverendo", etc.) es utilizado en forma irónica para poner en escena varios puntos. Primero, el prejuicio catalán contra lo inmigrante, pues a Salvador, que define a Paco como "un andaluz", le sorprende su éxito. Segundo, los orígenes de Salvador y su alianza con el franquismo. Tercero, en clave irónica, si la posición política de Salvador se asocia con su vinculación al franquismo, considerarlo "una prueba del desarrollo del país" es, precisamente, afirmar lo contrario. En cuarto lugar, subrayar la pertenencia de Paco a lo Propio por línea materna.

La alianza entre religión y poder económico es también atacada por Paco en diálogo con Salvador. Le dice: “-Es inútil, Salva, créeme -le dije bostezando. -Por cada obrero que lográis que descubra a Dios, hay diez que descubren vuestros ingresos. Corren malos tiempos. Estáis perdidos" (265). Hay quizá en este punto también una cierta ventriloquía, en la que el autor se sirve de la voz narradora para llevar a cabo una crítica social. Mainer afirma: "Sabe que de la casta de los Salva Vilella salen los counsellers de Convergencia i Unió con su simpatía 'cuadriculada, tenaz, deportiva'. Y que las pastorales nacionalistas de los obispos de hogaño tienen todavía el aroma rancio — excursionismo y sardana—de aquellos cursillos de Cristiandad que pintan con gracejo inigualable los capítulos centrales de la novela" (“El vengador” 249).

De hecho, la crítica más feroz contra la institución religiosa se lleva a cabo en la sección intercalada "El pintalabios o los misterios de colores", en los apartados 15, 17, 18 y 19. Para Pascal-Casas, “estos capítulos tienen [...] un papel primordial en la comprensión de la denuncia de la alianza Iglesia-Burguesía que se vale de la religión para mantener una situación política 
que les beneficia" (124). Montse envía a Manolo a un curso de cristiandad, con la excusa de que allí conseguirá los contactos para lograr un buen empleo. El curso se inicia:

El representante del obispo pronuncia unas sencillas palabras de salutación y bienvenida, de pie, con su bondadosa sonrisa y su sotana que por delante le queda corta, bienvenidos a Colores, a Casanovas que es vuestra casa, las manos cruzadas sobre el vientre que parece un melón, aquí viviremos juntos intensas jornadas de oración y estudio, de Colores son llamados también estos cursillos de cristiandad, como algunos ya saben, y quiere decir precisamente esto, que nosotros admitimos todos los colores, todas las tendencias, todos los criterios, conceptos y postulados del mundo, porque de colores se visten los campos y la primavera, los colores de la vida misma con el esperit de germanor que tan bellamente simboliza nuestra sardana, bienvenidos los valientes y una especial recomendación: cualquier problema o duda o conflicto espiritual, por muy personal que sea, debemos exponerlo con toda confianza y libertad a los profesores [...]. (140)

Nuevamente, Marsé se sirve de un tono irónico para presentar este espacio, que presenta la apariencia de apertura e integración (“juntos”, "todos los colores”, etc.) pero que esconde, a su vez, el de la vigilancia y la obediencia, manifiesto en la perífrasis verbal "debemos exponerlo". Además, se inscribe al curso en el espacio de la catalanidad, a través de menciones a símbolos identitarios ("sardana") y de expresiones en lengua catalana (“espíritu de hermandad").

El tema de la represión sexual es llevado a un extremo risible a través del despliegue de un discurso irónico asociado al curso de cristiandad. Los participantes del curso deben confesar sus prácticas sexuales, y ser absueltos por los sacerdotes. Los representantes del curso comienzan, el primer día, por "balbucea[r] conceptos infantiles sobre la abstinencia, la castidad, la verdadera hombría, el aguantarse” (153), para potenciar la violencia de su discurso conforme pasan los días, hasta llegar a ser inquisitorio:

[E]l asedio salvífico no ha hecho más que empezar: uno tras otro, profesores, curas y ciertos cursillistas aventajados lo abordarán desde este momento proponiéndole un acto de humildad en la capilla como primera e indispensable medida para obtener la tan difícil felicidad. Lo acosarán en los pasillos, en el 
comedor, en el dormitorio, durante el recreo, incluso en los lavabos, mientras orina chorros de malhumor: Póstrate en el sagrario, solo, y pide que si hay algo dentro, se te manifieste. Le sujetan del brazo y le tiran de la manga, es zarandeado, empujado, arrastrado casi, pero inútilmente. (168)

La imposición del grupo dominante sobre el sujeto dominado (que resiste) se observa en la posición de objeto que ocupa Manuel a nivel textual, reforzada en el sistema verbal asociado a la idea de un subyugamiento de creciente violencia (abordar, acosar, sujetar, tirar, zarandear, etc.). En el tiempo presente de algunos verbos, y en el modo imperativo de otros, se potencia la idea de subordinación y el carácter de permanente de ese acoso. En el término "asedio salvífico", por otra parte, genera un efecto humorístico a través de la ironía. Lo autóctono se asocia así con la religión, y también con la reproducción de un sistema de ideas que contribuye a su posicionamiento como sector dominante.

Por otra parte, al igual que en Últimas tardes, Marsé recupera aquí el tema de la lengua catalana como signo identitario. Al volver Paco a Barcelona, se encuentra con Nuria, quien le habla en catalán:

-iPero si es Francesc! -corriendo hacia mí, que me balanceo como un monigote ante tu tentativa de besarme la mejilla. -Ja no em coneixes? ¡La Nuria...!

$-\mathrm{Ah}$, claro... La verdad, no te habría conocido. - Y la consiguiente aclaración: he olvidado casi por completo el catalán. (66)

También su relación con la lengua coloca a Paco en una posición de borde, pues entendía la lengua cuando era niño, pero la ha olvidado "casi por completo". Nuevamente, un diálogo entre Paco y Salvador resulta productivo para analizar los modos de uso de esa lengua por lo Propio:

-Parles català?

-No.

-Però l'entens.

-Mal. 
-Però una mica sí.

-Mal.

-Però lo suficient, vamos...

-Pues no, chico. Lo siento. A ver, espera: setze jutges mengen fetge...

-No importa, la verdad. Bien mirado, las cosas como sean, no estás obligado.

-Espero que no, bien mirado.

-Ya lo aprenderás, hombre.

- Con la ayuda de Dios.

-Claro. Montse Claramunt, tu prima, me ha dicho que de niño habías vivido aquí y lo hablabas bastante bien.

-Lo olvidé. Pero lo estoy aprendiendo, quiero aprenderlo, sí, aprenderlo. Con la ayuda de Dios. (89-90)

Se observa la insistencia de Salvador en lograr que Paco hable catalán. A pesar de que Paco le contesta en castellano, Salvador reitera sus preguntas en lengua catalana, lo que pone de manifiesto su intención "asimiladora", anuladora de la diferencia. El hecho de que afirme que "no está obligado" implica que para Salvador hablar catalán es una obligación para quien ha nacido en Cataluña. La referencia irónica a la "ayuda de dios" corrobora la alianza con la religión católica observada por Paco.

Finalmente, La oscura historia recupera, como Últimas tardes, el significado del seny. Por un lado, se textualiza, al igual que en la novela anterior, como un sentido práctico que - se supone — facilita la resolución de problemas: “Tu padre inició desde el primer día una serie de gestiones, secundado por Vilella, encaminadas a recuperar a Montse. Todo se hizo con la máxima discreción y tío Luis se mostraba confiado: daba ya por seguro que la estupidez de su hija no era cosa pasajera, pero al mismo tiempo confiaba y esperaba ese momento que su impune experiencia de empresario gustaba definir como 'la hora de enseñar los triunfos"' (246). El campo semántico vinculado a lo empresarial ("gestiones", "empresario") pone de manifiesto que el seny, es decir, la sensatez, muchas veces no contempla lo afectivo. La familia Claramunt hace todo lo que indica el sentido común para recuperar a su hija, pero no le brinda la contención que su discurso religioso pregona, y Montse se suicida. La idea del seny cobra relevancia, entonces, en esta novela, ya no como sensatez sino como anulación de la capacidad 
de empatía. De hecho, el narrador se sirve de este concepto para describir la lógica excluyente y binaria Propio/Otro que se configura en la sociedad catalana:

No es la reciente experiencia de la cárcel (aunque allí dentro también el tiempo establece jerarquías, selecciona, quita o da prestigio, inviste poderes o degrada) sino un superior sentido del que se sabe huésped no grato en la hermosa ciudad apestada, Barcelona, capital del desamparo emigrante, cortesía de archivo y de este sutil refinamiento de preclaros mamarrachos que se ha dado en llamar seny. (207)

Se observa la textualización de las contradicciones del seny en construcciones sintagmáticas disyuntivas, en las que los términos de la disyunción son radicalmente opuestos ("quita o da prestigio", "inviste poderes o degrada") y en sintagmas antitéticos, casi oxímoros, en los que un término invalida al otro ("hermosa ciudad apestada", "sutil refinamiento de preclaros mamarrachos"). En las construcciones nominales "huésped no grato", “capital del desamparo emigrante" se hace visible el rechazo al inmigrante de modo directo, ya sin ironía.

En conclusión, La oscura historia se configura como el segundo paso en la construcción de un discurso nacional catalán de bordes difusos. A través de ciertos personajes como Montse y Paco, y de la textualización de ciertos espacios, Marsé abre la posibilidad de la hibridez y del cruce, lo que evidencia la fragilidad de las fronteras que separan lo catalán de lo foráneo. Si en Últimas tardes se delineaba una sutil zona gris, en La oscura historia se redobla la apuesta y se instaura un narrador mestizo. Este narrador, además, estructura una de las historias de la trama apoyándose en su propia memoria de los hechos, y afirma la falibilidad de estos mecanismos. De este modo, erosiona la idea acrítica del autor como autoridad máxima del texto, y estalla el concepto de narración como un relato unívoco y exclusivo. Así, pone en jaque la validez unitaria de todo relato, incluso del relato de nación, y abre el juego para que se consideren otros relatos (apócrifos) sobre lo que constituye la nacionalidad catalana. La crítica a la alianza entre la iglesia católica y la burguesía contribuye a erosionar el relato oficial, de 
bordes fijos entre lo catalán y lo inmigrante. Se visibiliza la arbitrariedad de estos bordes y de sus significados asociados, y se cuestiona su infranqueabilidad.

Es cierto, por otra parte, que en la novela la incorporación armónica de la Otredad en su diferencia no se presenta como algo armónico: Paco vive muchas veces su hibridez con angustia, y Montse opta por el suicidio. Al echar luz sobre estos conflictos, Marsé también subraya el perjuicio generado por la exclusión, lo que puede invitar al lector a la reflexión sobre su propia conducta naturalizada. Además-y fundamentalmente-creemos que La oscura historia hace visible la posibilidad de que lo Otro y lo Propio se mezclen, lo que es inadmisible dentro de la definición clásica de nación, y en esto vemos una redelimitación del concepto. La oscura historia es una apuesta, entonces, por la difuminación de fronteras, por la apertura a una nueva idea de nación que, aunque entraña tensiones y conflictos, es ahora porosa al mestizaje.

El próximo capítulo se detendrá en el estudio de El amante bilingüe, última novela a analizar en este trabajo. Publicada veinte años después que La oscura historia, El amante bilingüe recupera el tema del migrante del sur. Sin embargo, esta vez el tópico se presenta de un modo diverso, pues las figuras del sureño y del catalán coexisten en un mismo personaje que padece un trastorno de personalidad múltiple. El amante bilingüe, veremos, problematiza las contradicciones y las tensiones existentes entre estos dos universos, al tiempo que, simultáneamente sugiere su intercambiabilidad. El personaje de Marés/Faneca/el Torero Enmascarado es plausible de afirmar, como Rimbaud, "yo es otro”, pues encarna en sí mismo lo catalán y lo foráneo. 


\section{Capítulo 4}

\section{El amante bilingüe: la destrucción de fronteras entre lo Propio y lo Otro.}

Publicada en 1990, El amante bilingüe fue galardonada ese mismo año con el premio Ateneo de Sevilla. La trama de la novela, reconoce Marsé, comienza a tomar forma algunos años antes, en 1983:

[C]apté su primer latido hará cosa de siete años, en el transcurso de una conversación con Ana María Moix y la psicóloga Rosa Sender. Rosa me contó la historia de un paciente suyo que sufría una especie de esquizofrenia: era catalán y de familia muy catalana, pero se vestía y hablaba como un charnego de ley [...]. Y se me quedó la imagen de este hombre anhelando ser otro, cambiar de lengua y de aspecto y tal vez de identidad. (Marsé "Primera imagen")

Efectivamente, la novela narra la historia de Juan Marés, un catalán de origen humilde casado con Norma Valentí, quien pertenece a la alta burguesía catalana. Una tarde, Marés regresa a su casa, descubre que su mujer lo engaña con un lustrabotas del sur y ella decide abandonarlo. Marés permanece en el departamento conyugal, y comienza a tocar el acordeón por las calles de Barcelona para asegurar su subsistencia. Un día, mientras ejecuta su instrumento en la calle, recibe una bomba molotov en un enfrentamiento callejero con tintes políticos y su rostro queda desfigurado. Marés toma ventaja de la alteración de sus rasgos faciales para crearse una identidad nueva. Conociendo la debilidad de su exmujer por los inmigrantes del sur, decide representar a un personaje sureño, Juan Faneca, para recuperar a Norma.

Situada mayoritariamente durante la campaña de normalización linguística de la lengua catalana, "la novela trata, aunque de un modo un tanto indirecto, de la precaria condición 
bilingüe de la sociedad catalana, a la que el autor ha llamado 'esa especie de esquizofrenia cultural y lingüística de Cataluña"” (Kim 357). No queda duda, entonces, de que el eje principal de la novela es el tema de la identidad. Andrew Deiser confirma que este concepto se despliega en tres frentes distintivos e interrelacionados: el de la crisis personal de identidad de Marés, el de la cuestión de la identidad lingüística, étnica y de clase en Barcelona y, en un sentido más amplio, el de la noción de la identidad catalana (68). Esta es una novela extensamente abordada por el discurso crítico, sin embargo, la mayoría de los estudios se centran en la cuestión linguiística, tema que abordaremos — en relación a las tres novelas revisadas —en el capítulo próximo.

El presente apartado se dedicará al análisis de ciertas estrategias narrativas y discursivas que contribuyen a estructurar una idea de difusión de fronteras entre lo Propio catalán y lo Otro en El amante bilingüe. La novela, en primer término, se abre a una red múltiple de relaciones intertextuales desjerarquizadas, en donde distintos discursos provenientes de diversos tipos de textualidades coexisten armónicamente, dando lugar a un texto unívoco al tiempo que heterogéneo. Esta estrategia narrativa, de tipo metaliteraria, sugiere la idea de la novela como un espacio eficaz en el que coexisten discursos históricamente vinculados con la alta cultura y con la cultura popular, tradicionalmente planteadas en términos binarios. Por otro lado, y también dentro del ámbito de la reflexión metaliteraria, registraremos también que la novela se configura como un texto ambiguo en relación a su identidad cultural. Este capítulo revisará también las estrategias discursivas a partir de las que se construyen diversos personajes que encarnan conflictos, tensiones y superposiciones de los espacios catalán y migrante. Cobran aquí particular relevancia el personaje dual de Juan Marés/Faneca, catalán y migrante al mismo tiempo, y la figura de síntesis, el Torero Enmascarado, personaje asumido por Marés/Faneca para ganarse la vida en las calles de Barcelona. Asimismo, los espacios geográficos pierden en esta novela su exclusividad, y se vuelven híbridos, habitados y representativos al mismo tiempo 
de los ámbitos vinculados con lo tradicionalmente local y con lo migrante. La configuración de esta zona de identidades y espacios superpuestos constituye el tercer paso en la construcción de un discurso nacional catalán de fronteras móviles - y a veces estalladas — entre lo Propio y lo Otro. Creemos que, aunque esta novela hace manifiestas las contradicciones y los conflictos propios de estas superposiciones, es la más corrosiva de la supuesta claridad de bordes entre lo nacional catalán y lo foráneo.

Publicada sólo dos años después del infarto de miocardio que sumió a Marsé en "una especie de tiempo muerto, de bache" (Amell 101), El amante bilingüe es una novela breve, aunque estructuralmente imbricada. De hecho, Marsé confiesa que su escritura le resultó trabajosa: "[V]oy trabajando, pero muy lentamente, porque tengo un problema de estructura. Es una novela muy compleja, completamente distinta a lo que hasta ahora he hecho" (Amell 100). El libro cuenta con dos paratextos generales; el título y la dedicatoria. El título hace referencia a los dos temas que dan cuerpo a la novela, imbricándose constantemente: en el término "amante" resuena la idea de vínculo amoroso, y también se aporta una connotación erótica, presente a lo largo del texto, lo que configura el primer gran tema de la trama. El adjetivo "bilingüe", por otra parte, se vincula con la situación lingüística de Cataluña, segunda materia de vital importancia en esta novela. Tanto "amante" como "bilingüe" son términos que remiten a la idea de dualidad.

También remite a la idea de duplicidad la dedicatoria "Para Berta. Y para mis otros padres, y mi otra hermana, al otro lado del espejo", que presenta un elemento-tropo en la novela, el espejo. El espejo no solamente funciona como una de las múltiples operatorias de duplicación de los personajes, sino que también filia a El amante bilingüe con una determinada tradición literaria, en la que también se insertan, por nombrar algunos, el mito de Narciso, Alicia a través del espejo, de Lewis Carroll, o El retrato de Dorian Gray, de Oscar Wilde. Veremos más adelante que una de las características de la etapa literaria que Joan Oleza 
denomina "realismo posmoderno", en la que juzgamos que se integra esta novela, es la de la reapropiación simultánea de una multiplicidad de tradiciones estéticas. Esta dedicatoria también permite establecer una relación con la biografía del autor. Nacido, como ya hemos revisado en el primer capítulo, bajo el nombre de Juan Faneca Roca, Juan Marsé fue adoptado por el matrimonio Marsé-Carbó. Al referirse a su "otra" familia, el autor se aproxima a su personaje al desdoblarse, $\mathrm{y}$ al hacer visible su propia identidad escindida. Por otra parte, también en la dedicatoria a "Berta"-el único término del paratexto que no se acompaña con el adjetivo "otro"- - hay una repetición, ya que este es el nombre de su madre adoptiva y también el de su hija.

A continuación de la dedicatoria, el libro se dispone en dos partes de extensión similar, de veinte capítulos cada una. Todos los capítulos de la novela se identifican con un número arábigo, a excepción de los tres que corresponden a los cuadernos de memorias que Marés escribe a su exmujer. Nos referiremos a estos cuadernos en breve.

Cada parte se encuentra encabezada por un epígrafe. El primer epígrafe es una cita textual del filósofo apócrifo Juan de Mairena, creado por Antonio Machado: "Lo esencial carnavalesco no es ponerse la careta, sino quitarse la cara”. Esta cita, proveniente de "Carnaval”, del libro Juan de Mairena. Sentencias, donaires, apuntes y recuerdos de un profesor apócrifo se encuentra atravesada por la idea del doble, y "nos reta a vivir un momento de sinceridad, mostrando hacia afuera la verdadera personalidad" (Kim 358). En este sentido, la cita se aproxima al concepto del teatro clásico de "persona", aquella máscara fija—la de galán, la de villano, la de doncella—que permitía al público identificar sin demoras el rol de cada actor en la trama de la obra. Así, se dibuja una equivalencia entre el rostro y la máscara, y puede plantearse la posibilidad de que el propio rostro sea una máscara ante los demás. Kwang Kim sigue esta línea y observa el contraste con la situación de Marés, quien se disfraza—se "enmascara" - para recuperar a su exmujer. De hecho, con el objetivo de volver 
a encontrarse con Norma, Marés "renuncia a su personalidad y se transforma en un ser diferente" (358). Sin embargo, también puede sostenerse que la mención al carnaval no se opone sino que se aproxima al protagonista, ya que la posibilidad de "quitarse la cara" implica, en cierta medida, un deseo de ser otro, de transmutar de personalidad.

El hecho de que la cita textual del epígrafe lleve la firma de Antonio Machado, pero pertenezca, en realidad, a una de sus máscaras autorales, contribuye al efecto especular de multiplicación de las identidades. Así, se observa una relación con el cuadro psiquiátrico de personalidad múltiple que manifiesta el protagonista de la novela, además de las posibles vinculaciones con la figura de autor. ${ }^{65}$ De este modo, cabe la posibilidad de que Faneca sea el sujeto verdadero, el que vive debajo de la cara (y también, el apellido biológico de Marsé), y Marés, el falso (la cara que necesita ser removida para visibilizar el ser verdadero). La idea de la intercambiabilidad entre la máscara y el sujeto también permite contemplar la posibilidad de que tanto Faneca como Marés sean verdaderos al mismo tiempo, lo que estaría en concordancia con las ideas posmodernas del estallido del sujeto. Podría afirmarse, por otra parte, que ninguno es real, y detrás de la máscara no hay nada, sólo reflejos que se replican, dos espejos enfrentados. En la probabilidad de que todas estas opciones sean factibles se refleja la confusión total de fronteras entre los dos personajes (el catalán y el sureño) que lleva a cabo Marsé en esta novela. Es importante destacar que la convivencia de las dos identidades en el mismo personaje no es retratada por el autor de un modo armónico, y el personaje dual atraviesa estos procesos de forma angustiosa. Sin embargo, consideramos que la idea de la coexistencia de lo catalán y lo migrante en un mismo personaje - a lo largo de prácticamente toda la novela - constituye una estocada fatal al concepto de nación en términos clásicos, al hacer estallar sus bordes.

\footnotetext{
${ }^{65} \mathrm{Si}$ bien no nos detendremos en este tema en esta tesis, cabe recordar que el discurso médico hegemónico en el que se estructura el diagnóstico psiquiátrico de trastorno de personalidad múltiple también enraíza en una concepción binaria (salud/enfermedad) propia de la modernidad, que no contempla espacios de hibridez. Así, este discurso se articula también con el nacionalista en términos binarios Propio/Otro.
} 
La segunda parte se inicia con un epígrafe de T. S. Eliot: "Hay épocas en que uno siente que se ha caído a pedazos y a la vez se ve a sí mismo en mitad de la carretera estudiando las piezas sueltas, preguntándose si será capaz de montarlas otra vez y qué especie de artefacto saldrá". ${ }^{66}$ Esta cita puede vincularse con la situación de identidad estallada que transita Marés, un personaje de mediana edad ("en mitad de la carretera"), producto de su trastorno de personalidad múltiple. Marés se auto-arma como sujeto-Faneca, montando las piezas sueltas de su personalidad fragmentada. Kim sugiere que el epígrafe de Eliot "transmite a la perfección el estado azaroso en el que se encuentra Joan Marés tras alcanzar su sueño. Ahora tiene que enfrentarse a una circunstancia mucho más confusa: la nostalgia de ser otro y la angustia de arrastrar una identidad ajena" (358).

Nos hemos referido a los cuadernos de memorias de Marés, que se titulan "Cuaderno 1", "Cuaderno 2" y "Cuaderno 3" y cuentan con un subtítulo que resume la materia de la que se tratan. La voz narradora de estos cuadernos es la de Marés en primera persona, lo que, como observa Adolfo Sotelo, aporta verosimilitud al relato. Sotelo cita a Vilanova, y afirma que estos cuadernos "tienen la cualidad de dar 'la impresión de experiencia vivida, de absoluta autenticidad, y disipar el recelo y la desconfianza del lector respecto de la veracidad de la ficción novelesca', consiguiendo introducir en la linealidad del relato elementos temáticos imprescindibles para su entera comprensión” (385). Sin embargo, King observa que esta impresión de autenticidad es ilusoria: "La declaración de Norma sobre la incapacidad de Marés de representar 'lo que realmente es' y las declaraciones propias de Marés en las que admite que él mismo ha adoptado una identidad falsa (o no totalmente verdadera) cuando le ha sido necesario, ponen en duda la veracidad de sus memorias" (“Desempeñar" 77). Por otro lado, la

\footnotetext{
${ }^{66}$ Hemos rastreado intensamente el origen de esta cita, sin éxito. Al entrevistarlo, hemos consultado a Marsé sobre sus fuentes. No las recuerda con precisión, aunque afirma que no es apócrifa. Quizá en la mención a Eliot también pueda adivinarse la influencia de Gil de Biedma, gran admirador de su obra (tradujo, de hecho, el ensayo Función de la poesía y función de la crítica (1933, 1968 trad.)). El artículo de Elisenda Marcer citado al final de esta tesis profundiza el tema de la influencia de Eliot en Gil de Biedma, y en la Escuela de Barcelona en general.
} 
autenticidad de estos textos autobiográficos debe ser puesta en duda no solamente debido al carácter elusivo de la "verdadera personalidad" de Marés, que se diluye entre los juegos de espejos y la psicosis, sino también debido a la finalidad de estos cuadernos. Marés escribe con el fin de recuperar a su esposa, y en este sentido, no es despreciable el matiz persuasivo que subyace a su autorrepresentación como sujeto-protagonista de sus propias memorias. La supresión, por un lado, de ciertos elementos que Marés ha elegido no narrar, así como la exageración, quizás, de otros, producen una escritura auto-justificatoria, ocasionalmente victimizante, que reclama un lector receloso de la veracidad de lo narrado.

El primer cuaderno—que es también el primer capítulo de la novela—se titula "El día que Norma me abandonó”, lo que le otorga máxima preponderancia a este hecho. La partida de Norma es lo que el discurso médico psiquiátrico denomina "episodio desencadenante", es decir, el hecho que dispara la psicosis. Los críticos Luis Fombellida y José Sánchez apuntan que el trastorno disociativo de identidad encuentra su origen en una vivencia psicotraumática, frente a la que surgen "nuevas personalidades para adaptarse a situaciones conflictivas, creando estructuras alternativas" (7). Este suceso es además el episodio desencadenante de la novela, que pone a funcionar la máquina ficcional. El cuaderno narra, en primera persona, el recuerdo de la relación entre Marés y Norma: Marés afirma que la conoce haciéndose pasar por un militante de izquierdas. Más adelante, informa que "esporádicamente actuaba en agrupaciones teatrales de aficionados en Gràcia” (18), lo que nuevamente da cuenta del hábito de fingir otras identidades, previo a su desorden psiquiátrico. Por otra parte, en la figura de Marés como escritor de sus memorias vuelve a repetirse la idea de duplicación, en tanto el Marés autobiógrafo representa al Marés autobiografiado. El "Cuaderno 1" funciona como introducción a la totalidad de la novela, y hace visibles algunas de las ideas que se reiterarán en el desarrollo posterior: el tema del espejo y la debilidad de Norma por los hombres del sur. 
El "Cuaderno 2", situado en séptimo lugar en la primera parte, lleva por subtítulo "FuChing, el gran ilusionista" y narra algunos momentos de la infancia de Marés. Se detiene en la figura de su padre, un ilusionista que se hace llamar Fu-Ching y se disfraza de mago chino. A lo largo del capítulo, Marés narra en primera persona ciertas vivencias con su padre, al que nombra por su alias chino; sólo una vez informa: "El mago Fu-Ching se llama en realidad Rafael Amat, ahora me acuerdo" (41-42) ${ }^{67}$ La figura del padre es también entonces una figura duplicada, enmascarada, que actúa "de otro" y del que Marés afirma que es un "embustero, pobre embustero" (44). Fu-Ching/Rafael Amat no solamente viste un disfraz, sino que además disfraza su habla, lo que más adelante hará el propio Marés: "Fu Ching agladece los aplausos del distinguido público [...]. Señolas y señoles, glacias. Glacias” (42). En este sentido, quizás es otro personaje que puede vincularse con la idea de "bilingüe". Fu-Ching es alcohólico, no vive con Marés, y "aparece y desaparece" de la vida del niño. El capítulo presenta a su vez a la madre de Marés, que "fue una cantante lírica bastante conocida" (39) y se reúne los sábados con sus "viejos amigos de la farándula, retirados ya de la escena o fracasados y olvidados" (39). Marés crece entonces entre actores y disfraces, atravesado por las ideas de duplicación y representación. Además, es relevante destacar aquí el hecho de que si bien el padre de Marés tiene un apellido catalán, su madre se llama Rita Benítez, lo que permite interpretar que no es de origen catalán aunque a lo largo de la novela se identifique consistentemente como uno. En este sentido, Marsé problematiza de otro modo la supuesta homogeneidad detrás de lo catalán, pues Marés, con su apellido (ya sea Marés o Amat), evidencia en sí mismo el carácter ficticio de la construcción de la homogeneidad de lo Propio catalán. Resina se refiere a esta contradicción cuando afirma que para Rafael Ninyoles y Francesc Vallverdú los orígenes socioculturales de lo catalán no presentan mayores problemáticas, Marsé critica y cuestiona la

\footnotetext{
${ }^{67}$ En el apellido del padre se comprueba asimismo el origen catalán de Marés. La novela no explica por qué Marés no utiliza el apellido de su padre. Según El gran libro de los apellidos y la heráldica, "Amat" es la "forma catalana de 'Amado', derivado del latín amatum, 'amado', 'querido"' (Elián 43). Juan Marés se identifica como catalán a lo largo de toda la novela.
} 
veracidad de esas identificaciones primarias, pues cabe la posibilidad de que las identidades culturales sean móviles y mixtas (“The Double” 96).

El tercer cuaderno - capítulo tres de la segunda parte — se denomina "El pez de oro", y relata la primera entrada del niño Marés, de diez años, a Villa Valentí, donde nacería Norma algunos años después. Nuevamente, se observa en este cuaderno el tema del disfraz, pues el protagonista gana monedas con un número de contorsionismo vestido de la Araña-Que-Fuma. Es precisamente el disfraz lo que lo acerca a Víctor Valentí, hombre de la alta burguesía catalana y futuro padre de Norma, de la misma manera que algunos años después su "disfraz" de militante lo va a acercar a su exmujer. Valentí le ofrece su primer trabajo, nuevamente asociado con el artificio: debe representar una araña maligna, con acento andaluz, en una obra nacionalista catalana, prohibida en esos años por la censura franquista. Nuevamente, se observan las duplicaciones de los personajes, ya que Valentí cree que el niño es sureño, pues éste imita el acento de sus amigos, que sí provienen del sur. El niño aprovecha el malentendido y finge aún más marcadamente el acento en la representación teatral. Esta función pone en escena el conflicto catalán-migrante, y nuevamente Marés lo encarna en sí mismo. Como premio por su actuación, Valentí le obsequia al niño un pez de oro, que se le pierde en el estanque de la casa. El pez de oro opera como el símbolo de una vida mejor que se le escapa de las manos, sensación que se duplica cuando Norma decide separarse de él.

La estructura de la novela puede relacionarse con la de la novela por entregas. JeanFrançois Botrel sostiene que este tipo de discurso se caracteriza por la concentración receptiva prioritaria en la fábula o argumento (123). La trama de El amante bilingüe se encuadra dentro de estas generalidades. Botrel sostiene asimismo que la estructura de este tipo de textos se asocia con su soporte material, el periódico, y con su lector modelo, popular. Debido a estas particularidades, la estructura de la novela por entregas se caracteriza por una pluralidad de partes breves (tipo de escritura denominada "de página aireada", debido a la cantidad de 
blancos de página), dirigidas a un lector para quien leer supone un esfuerzo. La articulación formal del discurso responde entonces a un modelo que se estructura en partes que a su vez se dividen en capítulos breves, atravesados por la oscilación necesaria para mantener el suspenso, pues "cada unidad de lectura proporciona al lector la satisfacción y la insatisfacción, que es evidentemente la que empuja a desear el acceso a la continuación del relato, a través de otra entrega" (Botrel 124). Esta es una de las posibles relaciones con la literatura de masas que establece la novela.

Aunque no se define con exactitud el marco temporal de la novela, el relato primario se sitúa durante la campaña de normalización lingüística de la lengua catalana, por lo que es posible imaginar que los hechos se desarrollan poco después de 1983. Los críticos sostienen que se ubica hacia 1985 (Kim 360) o 1986 (Sotelo 387), y sabemos que el desenlace del relato primario se da en 1989. La temporalidad es generalmente lineal, y sigue un orden cronológico.

Hay tres excepciones al ordenamiento temporal, tres anacronías retrospectivas que corresponden a los tres "Cuadernos". El "Cuaderno 1" localiza la partida de Norma "una tarde lluviosa del mes de noviembre de 1975" (9), lo que ha sido interpretado por un sector de la crítica como una mención velada al día de la muerte de Franco, el 20 de noviembre (Resina, W. Connor). De este modo, la historia de la psicosis de Marés se inicia el mismo día que Cataluña entra en una nueva etapa como nación: ya hemos apuntado que Marsé se refiere a "la esquizofrenia cultural y lingüística" de su tierra. Este cuaderno incluye un diálogo en el que Marés le cuenta al lustrabotas cómo conoció a su esposa, cuatro años antes, en 1971.

El salto temporal del segundo cuaderno "es una analepsis de cuarenta años de alcance y una amplitud de menos de un día" (Kim 361), en la que el joven Marés, de doce años, sostiene un diálogo con su padre Fu-Ching. Contiene episodios que profundizan el retrato del personaje, y resaltan la particularidad de la infancia miserable de Marés, hijo de dos artistas pobres y fracasados. La tercera anacronía lleva el hilo de la historia a la inmediata posguerra, en 1943, 
al encuentro con Víctor Valentí. En esta anacronía se presenta el personaje ("real”) Juan Faneca, un amigo de la infancia de Marés de origen migrante.

Como las otras novelas analizadas, El amante bilingüe se localiza en la ciudad de Barcelona. Sin embargo, esta vez los espacios ya no se definen como catalanes o sureños, sino que se superponen como zonas de tránsito de ambos grupos. La novela textualiza, en primer término, diversas áreas del centro, en las que circulan prácticamente todos los personajes principales: "los jueves, a eso de la una y media, Norma acudía a las oficinas centrales de la plaza Sant Jaume y media hora después volvía a salir en compañía de [...] Jordi Valls Verdú” (30), al tiempo que Marés ejecuta en su instrumento un conjunto específico de canciones en el mismo lugar: "Su repertorio habitual en esta zona urbana, alrededor de la plaza del Rey, la catedral y la plaza de Sant Jaume, siempre fue a base de Mozart y Rachmaninov y algo de Pau Casals, pero últimamente los viejos y románticos boleros le obsesionaban” (54-55). Se observa entonces que Marés toca el acordeón en la Rambla, Faneca camina por el Barrio Gótico, Norma y su pareja, el sociolingüista Jordi Valls Verdú, trabajan en el centro y se desplazan por la zona de la Plaza Catalunya.

El barrio del Guinardó también se escinde, pues es el espacio donde se localiza Villa Valentí, "una fantástica torre del Guinardó” (14), donde nació Norma y donde su padre, entre otros burgueses catalanes, llevó a cabo la resistencia cultural catalanista en tiempos del franquismo. Sin embargo, el Guinardó es asimismo el lugar donde creció Marés, en una zona del barrio habitada por migrantes, "los golfos sin escuela que merodeaban por el parque Güell y el Guinardó” (14).

La ciudad es entonces un espacio de identidades cruzadas, y es textualizada también a partir del elemento-tropo del espejo. Ciudad de espejos, da lugar a que Marés necesite confirmar su identidad permanentemente: "Entraba en los lavabos para mirarse en los espejos: en una ciudad esquizofrénica, de duplicidades diversas, pensaba, lo que el ciudadano indefenso 
debe hacer es mirarse en el espejo con frecuencia para evitar sorpresas desagradables [...]." (84). En plena campaña de normalización lingüística, de "situación de esquizofrenia cultural y lingüística" (Pérez 126), Barcelona se describe como un espacio de coexistencia de identidades diversas y multiplicadas. Es cierto que la superposición de identidades se presenta a través de la patologización, pero también es evidente que las fronteras inmóviles entre lo Otro y lo Propio se derrumban, y con ello la "tranquilidad" ficticia de un orden binario que, en realidad, no existe.

La novela presenta, a su vez, dos espacios interiores de relevancia. El primero es la pensión Ynes, situada en el número 312 de la calle Verdi, donde se instala Faneca una vez que se independiza de Marés. Ya hemos revisado la relevancia del locus de la pensión y sus vinculaciones con el universo inmigrante. De hecho, como veremos más adelante, la pensión es el lugar donde habitan los personajes asociados al ámbito de lo Otro, la señora Lola y su nieta Carmen. El otro espacio interior de relevancia es el departamento conyugal de Norma y Marés, donde vive este último. Este departamento se sitúa en el mítico edificio Walden 7, en la Avenida de la Industria, en la zona periférica de Sant Just Desvern.

El proyecto del Walden 7 nació en 1970, y fue diseñado por el grupo multidisciplinario "Taller de Arquitectura", dirigido por el arquitecto posmodernista Ricardo Bofill. Este grupo de trabajo surgió a partir de la pretensión de unir disciplinas como la ingeniería, la psicología, la filosofía y la arquitectura. Algunos de los miembros del grupo fueron los hermanos Anna y Ricardo Bofill, Salvador Clotas, Ramón Collado y José Agustín Goytisolo.

El Walden 7 se inspiró en la obra utópica de ciencia ficción del autor Burrhus Frederic Skinner, Walden Two (1948), aunque el término "Walden" como forma de agrupación social se hace público por primera vez en el libro Walden, o mi vida entre bosques y lagunas (1854), 
de Thoreau. ${ }^{68}$ El proyecto apuntaba a la construcción de una cantidad importante de viviendas autogestionadas, con la intención de emular una pequeña ciudad en vertical, formada por casas, departamentos, tiendas y calles internas. Pretendía asignar la mitad de la superficie a usos comunitarios, como escaleras, callejones y jardines. El proyecto se inscribe en una nueva reflexión sobre el habitar, en la que el edificio ya no se contempla como un bloque inconexo, sino como un conjunto de células que configuran una ciudad que aspira a la vida en común (Marzá y Moyano 21). Josep Miró agrega que el Taller de Arquitectura apuntaba a consolidar al Walden 7 como una nueva idea del medio urbano, en oposición a la perspectiva exclusivamente técnica y especulativa que atraviesa a la mayoría de los edificios actuales (21).

Debido al imperativo de que ningún espacio debía ser residual, el edificio se construye con forma de laberinto. Originalmente se planearon tres bloques alrededor de un patio común, sin embargo, por motivos económicos sólo se llegó a construir uno. También se modificaron las dimensiones de la zona comunitaria, y por las mismas razones, se aumentó el número de viviendas. En 1980, con sólo uno de los tres edificios construidos, se hicieron evidentes ciertas deficiencias en el proceso de construcción: muchas paredes se humedecieron, surgieron grietas dentro de los departamentos, se levantaron algunos pisos y comenzaron a desprenderse las losetas del recubrimiento exterior. Debido a la peligrosidad de estos desprendimientos, la administración del edificio decidió colocar unas redes negras para proteger a los habitantes. Poco después, quebró la empresa inmobiliaria encargada de la construcción de las otras dos torres. El edificio se rehabilitó durante la primera mitad de la década siguiente, y se concluyó en 1995.

Se establecen diversos paralelismos entre el edificio Walden 7 y algunos puntos de la novela. En primer lugar, el fracaso del proyecto comunitario de la izquierda se asocia con el

\footnotetext{
${ }^{68}$ En donde el sociólogo estadounidense expone sus ideas sobre los sistemas de vida fundados en su ideología sobre las relaciones entre la comunidad y el Estado.
} 
fracaso del matrimonio "progresista" de Marés y Valentí. Además, el progresivo desmoronamiento del personaje de Marés puede vincularse con el proceso de desprendimiento de las baldosas, que caen del frente del edificio. Así como las máscaras de Marés comienzan a caerse, también lo hace la "careta" del Walden 7, dejando a la vista el cemento gris. Este paralelismo es visibilizado en la novela:

Abajo, en torno al edificio, las losetas desprendidas del revestimiento se estallaban contra el suelo a intervalos regulares, produciendo un leve chasquido en las sumas de la noche, casi un gemido. Y Marés evocó a Norma y los primeros días que vivieron aquí, la felicidad compartida, los sueños. También este camaleónico edificio, que albergó tantas ilusiones en los años setenta, fue a su vez un sueño: un habitáculo concebido para la pareja antiburguesa y no conformista que Norma había imaginado representar ante sus amistades, un edificio, según su creador erigido para propiciar otras formas de vida y de relación y no sólo las de la pareja tradicional, para exaltar la libertad del individuo y la convivencia en comunidad [...]. Todo se había ido al traste, y Marés aún se preguntaba por qué oyendo caer las losetas en las tinieblas del exterior. (35-36)

Gene Forrest observa:

A pesar de que el sitio tiene un alcance simbólico mayor en la novela, sería difícil ignorar las irónicas implicaciones de la caída gradual del edificio (su 'deconstrucción')—-las baldosas rojas que cubren la superficie externa, separándose y cayendo en redes que abarcan toda la circunferencia del edificio - a la luz del brillante legado de Gaudí y el triunfo artístico de la Renaixença. (48)

Agrega que el desprendimiento de las losetas exteriores, particularmente en el contexto de la patética experiencia de Marés, "es un recordatorio irónico del fracaso contemporáneo en perpetuar el logro humanístico de Gaudí” (48). En este sentido, el Walden 7 encarna una multiplicidad de fracasos, que hacen manifiestos los contrastes entre el deseo de imponer nuevos modos de vivir, y la realidad tangible de no contar con los recursos para llevarlo 
adelante: Norma y Marés no logran el éxito en un matrimonio que aspira a superar el determinismo clasista, y el Walden se cae a pedazos, visibilizándose como un proyecto aislado, de un sector progresista, pero sin el apoyo social que, a través de la inversión, haría económicamente plausible la construcción del edificio. Tanto la relación de Norma y Marés como el proyecto del Walden 7 coinciden en hacer manifiestas tanto las buenas intenciones de modificar un cierto estado de las cosas, como la falta de solidez para llevar estos programas a cabo.

Con respecto a la voz narradora de El amante bilingüe, es preponderante la figura del narrador omnisciente, que aunque suele permanecer neutral, a veces no es objetiva y manifiesta cierto rechazo hacia algunos personajes (Valls Verdú, por ejemplo) y cierta simpatía por otros (Faneca, o sus amigos). Ocasionalmente, el narrador omnisciente se comporta como testigo. Esto se comprueba en la mayoría de la novela, no así en los cuadernos, que se narran principalmente en primera persona, con una gran cantidad de diálogos que contribuyen al perspectivismo. Sotelo se apoya en la pluralidad de voces narradoras para afirmar el carácter polifónico de esta novela, en la que se observan varias voces: "la confesional de Marés narrador, la esquizofrénica de Marés protagonista y la sarcástica del narrador del relato" (386).

El amante bilingüe, de 1990, puede encuadrarse dentro de lo que Oleza denomina "realismo posmoderno". Oleza reconoce dos miradas diversas dentro de la posmodernidad. La primera de ellas se asocia con la revista Tel Quel (dirigida por Philip Sollers), y alrededor de la cual se agrupan intelectuales como Julia Kristeva, Roland Barthes, Georges Bataille, Jacques Derrida, Michel Foucault o Jean-Luc Godard, entre otros. Esta línea pregona las ideas de la muerte del sujeto y de la representación (Lyotard), la muerte de la Historia (Fukuyama), la disolución del texto en la textualidad (Derrida). Para esta línea, ya no sería posible narrar-en tanto ya no es posible la representación-y ya no sería factible, tampoco, la posibilidad de plantear un sujeto unívoco, dada la premisa del estallido del sujeto. 
Oleza reconoce, sin embargo, otra línea dentro del pensamiento posmoderno, que apunta a la reapropiación de la tradición como herramienta para seguir narrando. El realismo posmoderno, como lo denomina, disuelve las incompatibilidades entre alta cultura y cultura de masas, y cruza estas dos líneas en relatos en los que se da una coexistencia pacífica y heterogénea de todo tipo de discursos (41). En este nuevo realismo son frecuentes los juegos intertextuales, lo que proporciona a la novela una inmensa red de alusiones, parodias, guiños de complicidad, "en cuya urdiembre se enriquece la significación de personajes y situaciones" (42). El gran tema que atraviesa este tipo de novelas es el de la indagación y la pregunta, más importantes en la posmodernidad—y más verosímiles, luego del fracaso de la modernidadque la respuesta, la explicación o la certeza.

Para Oleza, el nuevo realismo plantea la exigencia de seguir postulando una historia para poder transformarla y apunta al rescate de la pasión narratoria, aunque se representa al sujeto sin ingenuidad, descentrado y estallado. Sin embargo, defiende el hecho de que, aún fragmentado, ese sujeto aún puede seguir protagonizando (y escribiendo) historias. Esta línea estética apunta a una democratización de la idea de belleza: no jerarquiza materiales, ni formas, ni técnicas, ni procedimientos; lo masivo y lo alto dan forma a una nueva forma de realismo, más abierto y convocante. La realidad que se representa es bien identificable por el lector, aunque los modos de representación son diversos y heterogéneos. Las narraciones del realismo posmoderno se caracterizan por la abundancia de diálogos directos, una mirada minuciosa y documentalista sobre el medio social y sus conflictos, y una figura de narrador atravesado por incertezas e indeterminaciones. La temporalidad suele estar ligada a los acontecimientos y al modo que tiene el narrador o algún personaje de percibirlos, y muchas veces el tiempo de la historia es contemporáneo al de la publicación de la novela.

Oleza rescata cierto trabajo de Marsé y lo encuadra en esta categoría. El estallido identitario del protagonista lo integra cabalmente en la figura de narrador propuesta por el 
crítico, y la mirada documental que despliega Marsé en relación con la cuestión lingüística catalana — contemporánea, como hemos visto, al proceso de escritura de la novela—contribuye a una articulación en este sentido. Sin embargo, la característica más evidente que inserta a $E l$ amante bilingüe en esta línea historiográfico-literaria es la que consolida la inmensa red intertextual de referencias a todo tipo de discursos, que se entretejen, sin jerarquías, en la novela. Esta red intertextual funciona también en el ámbito de la reflexión metaliteraria, y sugiere que la novela puede ser un espacio abierto a la diferencia. En la extensa trama de ecos y apoyos simbólicos que dan cuerpo a la novela se lee también el valor constructivo de la diversidad como materia prima para la estructuración de un espacio cuya complejidad enriquece al conjunto.

En primer término, la figura de Marés se integra dentro de la tradición picaresca, pues el sujeto intenta evadirse de su situación económica a través del engaño y el enmascaramiento. El retrato del universo de la mendicidad corrobora esta filiación. La novela establece, a su vez, relaciones con el fin de siglo español, en primer lugar, a través de la mención a Antonio Machado en el primer epígrafe. En segundo lugar, ciertas descripciones—de la familia de Marés, de sus compañeros mendigos, del personaje de Griselda—tejen hilos evidentes con la tradición esperpéntica de Valle Inclán. Hemos ya revisado las vinculaciones entre esta novela y el folletín, a nivel estructural, como así también la conexión con la serie narrativa que integra el elemento-tropo del espejo. En esta línea, se observa una asociación con la tradición romántica victoriana, a través de la figura del doble (Dr. Jekyll y Mr. Hyde, de Stevenson). Las sombras y los fantasmas que persiguen a Marés aproximan la novela al género fantástico.

El amante bilingüe establece asimismo relaciones intertextuales con la telenovela, o la novela rosa, género parodiado en ciertas situaciones en las que Marés habla de Norma: “-Otra vez el loco amor después de tanto tiempo -se lamentó Marés-. Tu vida y mi vida, Norma. Recuérdame" (53). Son múltiples las referencias a ciertos boleros ("Perfidia", "Tatuaje”), al 
pasodoble ("Suspiros de España") y a la copla andaluza, "que años atrás hicieron populares Imperio Argentina y Estrellita Castro" (191). Se observan también menciones al universo cinematográfico, sobre todo en la segunda parte del texto, cuando Faneca le narra las películas al personaje de Carmen en la pensión Ynes. La novela alude a su vez al discurso científico: "El universo es un jodido caos en expansión que no tiene sentido" (34).

El libro dialoga, por otra parte, con la poesía catalana de la segunda mitad del siglo XIX:

Fue en el parque Güell. Ya éramos novios. Estábamos hablando del patriotismo de mis padres, de cómo me habían educado en el amor a Cataluña y a la senyera, y de repente me besó en la boca. Fue un beso larguísimo, y mientras duró, sin despegar en ningún momento su boca de la mía, me recitó el Cant Espiritual de Maragall. Era capaz de recitar las obras completas de mossèn Cinto mientras me besaba. (103)

También hay referencias a la poesía catalana de Josep María de Sagarra, pues el niño Marés recita sus versos en Villa Valentí. Existen, además, menciones al género musical de la sardana.

Las redes intertextuales que teje El amante bilingüe no solamente se extienden hacia el afuera de la serie literaria española, sino que también atraviesan el interior del propio universo ficcional de Marsé. De esta manera, se observan referencias inequívocas al cuento "Historia de detectives", incluido en la antología Teniente Bravo (1987). Sotelo observa la equivalencia casi palabra a palabra de la descripción del automóvil Lincoln donde los niños que protagonizan "Historia de detectives" se reúnen a conversar y el que describe Marés al comenzar el segundo cuaderno de sus memorias, al asociarlo con su madre. El crítico registra las correspondencias entre el retrato de la madre de Marés, sus amigos, y el mago Fu-Ching, y los mismos personajes en "Historia de detectives". Observa, además, que los amigos del niño Marés son "David, Jaime, Roca, Faneca" (Marsé 63), los mismos personajes que protagonizan el cuento incluido 
en Teniente Bravo (Sotelo 394). Hay, asimismo, una relación intertextual posterior, pues Marsé publica, en 1997, la antología de textos Las mujeres de Juanito Marés.

Esta coexistencia desjerarquizada de discursos heteróclitos puede considerarse una estrategia narrativa a través de la cual Marsé diseña en su novela un espacio híbrido, de cruce de tradiciones y de criterios-lo "alto", lo "bajo", lo "culto", lo "masivo". En la construcción de un espacio textual al mismo tiempo discreto y misceláneo el autor presenta una idea metaliteraria sobre la novela como un espacio abierto y convocante a todos los discursos, que conviven en una escritura que los integra y se nutre de esta diversidad, sin asimilarlos dentro de una mirada única y respetando sus características específicas. El amante bilingüe permite que la variedad se muestre a sí misma como diversa y, aun así, capaz de funcionar eficazmente en un todo. Es ésta, creemos, la idea de discurso nacional catalán que subyace a la escritura de Marsé, quien convierte a su propia novela en la prueba de la posibilidad de la integración de la heterogeneidad en su diferencia.

En la composición de los personajes de la novela Marsé despliega, asimismo, sus estrategias narrativas. Como en las novelas anteriores, el universo catalán y el foráneo se representan a través de diversos personajes, aunque en El amante bilingüe los cruces y superposiciones son más frecuentes e imbricados. Algunos personajes, sin embargo, aún conservan una relación unívoca con su ámbito, como es el caso del sociolingüista Jordi Valls Verdú, pareja de Norma en la trama central de la novela. Valls Verdú-como Luis Trías en Últimas tardes, y Salvador Vilela en La oscura historia-encarna cabalmente las características del universo de la catalanidad: de hecho, como indica Laura Connor, ya su nombre lo inscribe en este ámbito, pues Sant Jordi es el nombre del santo patrono de Cataluña (6). Lee encuentra patente la relación de proximidad entre Salvador y Jordi, y agrega que ambos personajes son retratados con sarcasmo y crueldad como "verdaderos" catalanes, y así como 
Paco disfrutaba de saber que estaba teniendo una aventura con la esposa de Salva, Marés/Faneca se regocija al socavar la relación entre Jordi y Norma (“Blind” 32).

Resina informa que el nombre de este personaje dialoga con el de Francesc Vallverdú, "un reputable sociolingüista y conspicuo defensor de la lengua catalana" ("The Double" 95) que, en una reseña sobre Un día volveré (1982), criticó a Marsé por su falta de catalanidad: afirmó que la novela no reflejaba que los sucesos narrados eran protagonizados por catalanes, pues la palabra "catalán” no aparecía con asiduidad en el texto. Vallverdú sugirió que esto podría resolverse escribiendo en catalán, que era, a su criterio, la lengua más adecuada para vehiculizar la especificidad nacional (95). Aunque nos detendremos en el tema de la lengua y su relación con las novelas y la identidad nacional en el próximo capítulo, sí observaremos que Marsé responde a esta crítica con la caracterización del

afamado sociolingüista Jordi Valls Verdú, peligroso activista cultural. Valls Verdú era el inmediato superior de Norma y su actual amante, y ocupaba un puesto de responsabilidad en la Comisión que llevaba adelante el Plan de Normalización Lingüística de Cataluña a cargo de la Generalitat. Marés lo había conocido diez años atrás robando volúmenes de la Bernat Metge en la vasta biblioteca del difunto Víctor Valentí, padre de Norma. (29)

La figura de Valls Verdú se construye así a través del contraste de dos ideas opuestas. Una de estas ideas se asocia con el prestigio, y se configura a través de términos como "afamado", “inmediato superior", "puesto de responsabilidad”, en relación con nombres capitalizados relacionados con la burocracia gubernamental. Se configura, de este modo, una cierta idea de “dignidad". Sin embargo, esta idea se desvirtúa en la última oración, cuyo sistema verbal la desautoriza. En primer término, el núcleo verbal "había conocido" instaura un sujeto diferente, Marés y presenta al sociolingüista en el lugar de objeto, atenuando el lugar de poder que ostentaba en la oración anterior. Esta última oración también degrada su función sintáctica, al colocarlo ya no en posición de sujeto de la estructura principal, sino de la proposición 
subordinada. En tanto sujeto y agente de esa subordinada, Valls Verdú se vincula con "robando", gerundio que sugiere una idea de acción en proceso, de continuidad del robo. Además, el objeto del robo—-libros del humanista catalán Bernat Metge_-hace aún más patente esta degradación, creando una idea de "indignidad". En el contraste entre estos dos conceptos, Marsé recupera la idea de hipocresía para referirse al universo catalán. El tono irónico contribuye a la crítica en este sentido.

Resina observa que la crítica a Valls Verdú-y a Vallverdú-también opera en otro sentido, pues el novelista se sirve de este personaje como un emblema involuntario de una actitud lingüística totalitaria que condena. Para Resina, el asunto real en juego es el de la legitimidad de la intervención institucional en el tema de la lengua: Marsé defiende el bilingüismo, ${ }^{69}$ frente a la mirada institucional, representada por Valls Verdú, que afirma la necesidad de tomar partido por la lengua catalana ("The Double" 95). Marsé se opone directamente a Valls Verdú en el tema de la situación lingüística de la región, pues no duda en defender el uso de las dos lenguas. Afirma que el tema de la novela se vincula "con la sociedad catalana, en la que hay una doble cultura, la catalana y la castellana, y luego es bilingüe, y lo es desde hace muchísimos años. [...] Yo nunca he tenido conflicto con eso, y no creo que sean excluyentes entre sí. [...] [T]e metes en un domicilio barcelonés, y te encuentras, como aquí, con esas dos culturas coexistiendo sin problemas" (Guisasola 281-82).

Valls Verdú recupera a su vez el significado asociado a la represión sexual catalana, no solamente porque Norma prefiere tener sexo con migrantes del sur- $-\mathrm{y}$, de hecho, lo engaña con Faneca-, sino también porque Marés se pregunta "cuánto tiempo le duraría a Norma esta aventura marrana y monolingüe, cuántos jueves más tendría él que venir aquí a instalarse en esta esquina sólo para ver pasar al objeto de su pasión y recibir, ocasionalmente, alguna moneda" (30). Marés sabe que el romance entre los sociolingüistas será breve, aunque a veces

\footnotetext{
${ }^{69}$ Resina aclara que realmente la situación es de diglosia, lo que discutiremos en el próximo capítulo.
} 
duda: "[T]al vez los charnegos ya no la enloquecían como antes y se conformaba con su actual amante, ese papanatas monolingüe" (170). Por un lado, los inmigrantes tienen la facultad de "enloquecer(la)", mientras que, por el otro, su amante es definido como una "persona simple y crédula o demasiado cándida y fácil de engañar”, según la RAE, y la relación se plantea en términos de conformismo.

El ámbito migrante se concentra en el espacio de la pensión Ynes, sobre todo en la figura de la señora Lola, la dueña de la pensión. Este ámbito vehiculiza, como en las novelas anteriores, el significado de la pobreza: “¡Ah, qué buenos tiempos aquellos, a pesar de todo! Se trabajaba mucho más. Si tardas un poco en venir, a lo mejor habrías encontrado cerrado [sic] [...]. De hecho, esto ya no es una pensión, no viene nadie" (164). Sin embargo, si en las novelas anteriores la idea de pobreza se vinculaba con la de la marginalidad y el delito, ahora se asocia al trabajo duro, lo que genera un nuevo significado de "pobreza digna", que hace manifiesta la preferencia por el espacio de la Otredad (frente a la “indignidad” de Valls Verdú). Lola sigue trabajando, a pesar de su edad: "Esa abuela tenía que ser la señora Lola, a la que él no veía desde hacía casi veinticinco años, cuando enterró a su madre. Estaba en el pasillo restregando el suelo con una fregona. Una mujer de casi setenta años, animosa y fuerte, de ojos vivos y dentadura poderosa" (163). El significado de trabajo duro se anuda con la fortaleza física a través de los adjetivos "animosa", "fuerte" y "poderosa".

A pesar de los casos específicos de Valls Verdú y de Lola, los personajes de mayor peso en El amante bilingüe presentan características tanto del universo sureño como del catalán, o bien se encuentran atravesados, de una u otra manera, por estas dos fuerzas en tensión. Norma Valentí, por ejemplo, parece encuadrarse cabalmente dentro del universo de lo catalán, pero veremos que también se asocia con el espacio migrante. El retrato que hace Marés de Norma al momento de conocerla replica el de Teresa, de Últimas tardes. Así, Norma “estudiaba filología catalana en la universidad y era una chica romántica y progre” (17), que 
conoce a Marés en una reunión catalanista, conspirando contra el franquismo. Forrest sugiere la posibilidad de que Norma y Faneca sean una versión transformada, de mediana edad y conformista, de Teresa y Manolo. Para Forrest, Norma es una Teresa que se ha osificado y deshumanizado, mientras que Faneca es un Manolo maduro, que ha perdido "junto con su motocicleta, sus blue-jeans y su camiseta, la ambición” (48).

Teresa, Montse y Norma son parte de la burguesía catalana, y las tres cuentan con más poder (económico, simbólico y social) que sus contrapartes masculinas. Tanto Norma como Montse se criaron en una torre aislada, y provienen de una familia de fuerte sesgo catalanista. Para Lee, el nombre de éstas últimas es emblemático para la época en la que cada novela se desarrolla: Montserrat personifica la sociedad católica catalana, conservadora e inflexible, dueña de su propia virgen, mientras que Norma encarna la autonomía catalana con su política lingüística específica. Ambas tienen un nombre que las inscribe en las redes del poder en Cataluña de una determinada manera ("Blind” 30).

Por otra parte, Norma es el nombre de un dibujo animado creado por el gobierno autonómico para enseñar catalán a los no catalanohablantes. Un amplio sector de la crítica considera que Norma representa a Cataluña y a su política lingüística normalizadora: "Así, Norma, como la lengua catalana, es un puente, una forma de acceder plenamente a Cataluña" (King “Desempeñar" 78). Tanto Laura Connor como Kim subrayan que Norma representa una imagen de Cataluña, la promovida por el Plan de Normalización Lingüística.

Su apariencia física inscribe a Norma asimismo en el ámbito de la catalanidad:

Era un dibujo yerto y frío y en él Norma seguía pareciendo feúcha con sus ojos almendrados detrás de los gruesos cristales de las gafas, su boca grande y sensual, su larga nariz montserratina y su pelo rizado y antiguo, una combinación extraña, tan difícil de explicar en Norma: no que fuese fea, pero que lo pareciese - del mismo modo que no parecía una mujer rica, y sin embargo lo era, y mucho- . Aunque el parecido del dibujo con la Norma real era escaso, este pintor fracasado y borrachín había captado la sutil luminosidad anacarada de la piel de Norma. A Marés no podía escapársele ese detalle porque 
el nácar de la nalga [...] se había instalado entre sus recuerdos como el primer compás de Perfidia. (55)

Este retrato recupera también el significado de lo claro asignado a lo Propio catalán, estructurado a través de la imagen visual "sutil luminosidad anacarada" y reforzado en la metáfora impura "el nácar de la nalga". La descripción también teje hilos entre Norma y la madre de Teresa, en tanto en ambas la catalanidad es asumida por una parte de su cuerpo: si la señora Serrat tenía “una pierna catalana”, Norma es definida por su "larga nariz montserratina". Más adelante, Marsé reiterará el recurso: “Seguía sin ser hermosa, pero conservaba, a sus treinta y ocho años, una espléndida figura y aquel aire de calculado extravío, una voz colorista y una sugestión ligeramente gaudiniana, como de cerámica troceada: un capricho en los rasgos, una ondulación en las formas” (97). De este modo, su apariencia física inscribe a Norma en el espacio de lo Propio y se identifica con ciertos elementos del repertorio nacional catalán hegemónico: la virgen de Montserrat y el mosaiquismo de Gaudí.

Sin embargo, a pesar de su origen y su compromiso por la causa de la lengua catalana, Norma "milita en el catalanismo solo de cintura para arriba" (Vázquez Montalbán "El amante" 407). Si bien sus elecciones legítimas — el matrimonio con Marés, su relación pública con Valls Verdú-la inscriben en el espacio de la catalanidad, sus decisiones fuera del ámbito de la legitimidad la acercan al espacio de lo Otro. Marés registra la ambivalencia que pone en juego las ideas de legitimidad y de deseo, y afirma: "Nadie lo diría, con lo fina y catalanufa que es. Ahora, para disimular, se ha liado con un sociolingüista independentista [...]. Tan seria y formal, la señora -prosiguió Marés lamentándose, apartando el plato de macarrones que apenas había tocado-- Pues ahí la tienes, lleva una especie de doble vida" (57-58). De este modo, Norma asume significados de los dos espacios: la hipocresía la vincula con lo Propio catalán, pero su libertad sexual la aproxima a lo migrante. Norma se configura como una mujer activa, que ejerce su sexualidad sin la represión característica de su grupo de origen. Además, su 
preferencia por los amantes sureños es uno de los motores de la novela. Esta preferencia sexual se relata en el primer capítulo, cuando Marés regresa al departamento conyugal y la encuentra con un lustrabotas:

Ya se está poniendo los calzoncillos, algo aturullado. Veo fugazmente su sexo oscilando entre las piernas. Es oscuro, notable. Apresuradamente se pone los pantalones y luego busca los calcetines en el suelo. En su cara un poco bestial no se ha borrado el susto, parece abrumado con su papel de amante ocasional de la señora de la casa pillado in fraganti por el marido. No me sorprende que sea un vulgar limpiabotas, probablemente analfabeto, reclutado en algún bar de las Ramblas y con pinta de cabrero. Cuando empecé a sospechar que Norma me engañaba, pensé en Eudald Ribas o en cualquier otro señorito guaperas de su selecto círculo de amistades, pero no tardé en descubrir que su debilidad eran los murcianos de piel oscura y sólida dentadura. Charnegos de todas clases. Taxistas, camareros, cantaores y tocaores de uñas largas y ojos felinos. Murcianos que huelen a sobaco, a sudor, a calcetín sucio y a vinazo. Guapos, eso sí. Aunque éste no parece tan joven ni tan irresistible. Un tipo de unos cuarenta años, moreno, de nariz ganchuda, pelo rizado y largas patillas. Un charnego rematado que no se atreve a mirarme a los ojos. (11-12)

La cita registra nuevamente asociaciones ya revisadas para el espacio de lo migrante.

Se observa, en primer término, un campo semántico erótico, constituido por términos como “sexo", "bestial", "amante" o "piel”, que recupera la vinculación entre lo Otro y la libertad sexual. Este significado se refuerza en el hecho de que el lustrabotas se retrata desnudo, vistiéndose luego de haber tenido un encuentro sexual con Norma. Además, hay un sistema de referencias que consolidan el significado de lo oscuro (en "piel oscura" o "moreno", por ejemplo), que se anuda en este caso al significado anterior, al describir al sexo como "oscuro" y "notable". El párrafo condensa también la relación entre lo Otro y la pobreza, en la enumeración de oficios de bajos ingresos ("lustrabotas", "cabrero", "taxistas", "camareros”), y reelabora asimismo la vinculación entre lo foráneo y el saber empírico, no institucional (“analfabeto"). 
Si Norma encarna el conflicto catalán-inmigrante en su vida sexual, Marés lleva esto al extremo y lo asume en toda la extensión de su persona. En la figura de Marés/Faneca, los bordes que hasta ahora parecían superponerse entre lo Propio catalán y lo Otro, ahora se confunden totalmente, a través de un trastorno de personalidad múltiple (doble), que hace de este personaje al mismo tiempo un catalán y un sureño. Como señala King, Marés/Faneca es un intento por parte del autor por trastornar la dialéctica entre catalanes y migrantes. Aunque King considera que este intento "no consigue su fin" ("Desempeñar" 76), intentaremos demostrar que esta confusión de fronteras es el tercer punto en la definición de un discurso nacional cuestionador de los límites fijos entre lo Propio catalán y lo Otro, sobre todo a partir de la figura del Torero Enmascarado, una de las identidades asumidas por Marés/Faneca para ganar dinero en las calles de Barcelona. Aunque concordamos en el hecho de que esta posibilidad se presenta como problemática, creemos que la coexistencia de las diversas identidades en un mismo personaje abre una posibilidad de comunidad inadmisible dentro de los límites específicos del concepto de nación clásica. Es desde esta perspectiva que, a pesar de lo conflictivo de la construcción, sí creemos que puede leerse como un nuevo paso en la constitución de una idea de nación de bordes estallados.

El personaje de Marés establece un primer vínculo con la figura de Marsé. Ambos son denominados "Juan" o "Joan", indistintamente, y sus apellidos se aproximan desde un punto de vista fonético. Por otra parte, ambos son catalanes y bilingües, aunque se desenvuelven normalmente en castellano (Kim 362). También coinciden su año y lugar de nacimiento, y el hecho de que ambos comienzan a ejercer un oficio desde los inicios de su adolescencia, Marés como lustrabotas y Marsé como cadete en una joyería. La relación de la figura autoral con el protagonista no se circunscribe a Marés, pues sabemos también que el apellido de la familia biológica del novelista, que fue adoptado por la familia Marsé Carbó, es Faneca Roca. 
Juan Marés es un personaje permanentemente atravesado por la tensión entre lo catalán y lo migrante, y, aunque sufre una transformación desde aquel universo a éste, manifiesta permanentemente las contradicciones propias de ambos universos. Su infancia se desenvuelve entre sureños, en un barrio popular. Pasa desapercibido entre sus amigos migrantes, al punto de que Víctor Valentí no duda de su origen:

El hombre del traje blanco se dirigió a mí en castellano porque me oyó maldecir en castellano. Él era catalán. Yo también, pero todos mis amigos de la calle, los chavales de la pandilla, eran charnegos - sobre todo Faneca, que era de un pueblo de Granada y hablaba con un acento andaluz tan cerrado que no se le entendía-, y con ellos yo siempre me entendía en su lengua. Mi cabeza rapada y mi aspecto desastrado, por otra parte, hicieron el resto: el señor elegante me tomó por un charneguillo de los muchos que entonces infectaban el barrio. (128)

Esta cita hace visibles ciertos significados. Primero, la asociación entre lo catalán y lo claro: Valentí viste de blanco y más adelante en la misma página se nos informa que es “canoso". Segundo, el bilingüismo de Marés: habla catalán, es catalán, pero se entiende en castellano con sus amigos de la pandilla. A pesar de que conforman un grupo de amigos, el sistema pronominal marca ciertas diferencias. Los pronombres personales "yo" y "ellos", en lugar de un "nosotros", corroboran la heterogeneidad del grupo. A su vez, el pronombre posesivo "su" que precede al sustantivo "lengua" hace patente que el castellano no es la lengua de Marés, sino la de "ellos". La estructura impersonal "no se le entendía”, por otra parte, que adjetiva el acento sureño de Faneca, sumada al aspecto imperfecto del verbo, otorga un matiz universal a esa afirmación: el acento no es comprendido en absoluto, y esto se enuncia en pretérito imperfecto, lo que le da a esta ininteligibilidad continuidad en el tiempo.

Tercero, como es catalán, el niño tiene interiorizada la mirada prejuiciosa de su ámbito de origen, y lee, entonces, el malentendido: sabe que no solamente su lengua, sino también su aspecto (caracterizado negativamente, en los binomios "cabeza rapada" y "aspecto 
desastrado") llevarán a Valentí a confundirlo con un inmigrante. Hacia el final de la cita, el niño Marés dice, como un ventrílocuo, las palabras prejuiciosas del ámbito de lo Propio catalán, reflejadas en el sustantivo "charneguillo", que, en tanto diminutivo, coloca a quien lo enuncia en un lugar de superioridad, y en el verbo "infectaban", cuyo aspecto imperfecto aporta continuidad en el tiempo al rechazo. Además, en el significado de "infectar”- “invadir un ser vivo y multiplicarse en él”, es la primera definición que ofrece la RAE—se concentra un prejuicio que asocia a la catalanidad la idea de pureza, y califica a lo migrante como un elemento patógeno y contagioso que viene a corromperla. ${ }^{70}$

Debido a que Marés conoce los prejuicios que tienen los catalanes sobre los sureños, y porque le resulta conveniente, el niño finge no saber hablar catalán (132). Exagera, de hecho, su acento: "La recito de corrido con un leve acento charnego que me sale muy bien" (133), porque sabe lo que se espera de un "sureño" como él. Va a representar al enemigo de Sant Jordi, y puede predecir lo que le pedirá más adelante Valentí: “-No te preocupes por el acento andaluz, deja que se note; es precisamente lo que yo quería" (133). Más adelante, ya adulto, Marés suele sacar provecho de su capacidad para habitar los ámbitos de lo catalán y de lo Otro. De hecho, uno de los disfraces que le representa mayor rédito económico se asienta en esta posibilidad, pues sabe que despierta la pena—y la limosna—de algunos catalanes: "Esta última pieza la tocó sujetando el acordeón con los pies descalzos [...]. [C]ausaba mucha pena a los viandantes. ¡Pobre—-pensaban—, además de charnego, contrahecho! Esguerrat! Una lluvia de monedas caía sobre la hoja de periódico" (56). Marés puede moverse entre los dos universos con facilidad, gracias a la coincidencia de su bilingüismo con su capacidad de representación.

En la maestría con la que Marés se mueve entre ambos ámbitos, Lee observa ciertas coincidencias con la figura de Paco, de La oscura historia. Afirma que ambos personajes

\footnotetext{
${ }^{70}$ Ya hemos revisado, en el capítulo 3 de este trabajo, las vinculaciones entre lo Otro y las ideas de suciedad y contagio.
} 
presentan una identidad ambigua y ambivalente, vivida con ansiedad. Encuentra una cierta identificación entre Paco y Manuel, en La oscura historia, y cree que esta identificación es llevada al extremo en la transición en la que Marés (a quien aproxima a Paco) termina deviniendo Faneca (en quien Lee lee a Manuel) (“Blind” 30-31). La ambigüedad de la identidad del personaje se observa incluso en su apariencia física, una vez que Norma decide irse del departamento conyugal:

Marés era un hombre de cincuenta y dos años, pero aparentaba menos debido a la caricia del fuego, desde que un grupo de exaltados nacionalistas catalanes que recorría las Ramblas en manifestación, tres años atrás, hallándose él sentado en esa misma esquina de Sant Pau, lanzó un cóctel Molotov-Tío Pepe con tan mala fortuna que se estrelló en la acera delante de él y le dejó el rostro y las manos de seda. El fuego diseñó en la piel de las mejillas una sonrisa perenne y burlona, una soñadora ironía. Desde entonces no tenía cejas y se las pintaba con lápiz negro de trazo grueso, pero en el entrecejo, al llegar la primavera, le crecían unos pelos largos y negros. En días de melancolía y añoranza, para animar una cara sin arrugas y sin pasado, sobre el severo labio superior se pegaba con almaste un bigotito postizo, rubiales y distinguido. Tenía Marés los pómulos altos y pulidos, el pelo ralo y los ojos color miel, pequeños y rapiñosos. (21-22)

Marés encarna físicamente significados asociados con los dos universos. Tiene, en primer término, "los ojos color miel”, claros, lo que lo aproxima al ámbito de lo catalán. Su accidente con la bomba molotov encubre una crítica al nacionalismo catalán (definido como “exaltado"), al tiempo que pone de manifiesto, nuevamente, la dicotomía catalán-sureño: la bomba molotov proviene de ciertos nacionalistas catalanes, pero es producida en una botella de jerez Tío Pepe, uno de los íconos de la ciudad de Jerez de la Frontera, en Andalucía. En el campo semántico que rodea a la idea del accidente con fuego, consolidado por términos como "caricia", "de seda", "sonrisa", puede interpretarse una cierta mirada positiva. Podría afirmarse que la alteración de los rasgos faciales de Marés abrió también la posibilidad de instaurar una nueva identidad desde dos frentes. "[S]in arrugas y sin pasado", Marés podía elegir quién ser, facilitado esto por la posibilidad del disfraz y el maquillaje. 
La identidad de Marés es ambigua desde un principio, pues cuenta con una batería de recursos para transformarse y asumir otras identidades. Norma dice de él que "Nunca ha representado lo que realmente es, ese hombre" (105) y él mismo comienza a dudar de su propia subjetividad: "Sospechó, lo mismo que el poeta, que detrás del rostro que le miraba no había nadie" (141). La idea del disfraz, entonces, no resulta sorprendente para quien se ha ganado la vida a través de la representación. La transformación física no solamente se asocia con la alteración de sus rasgos ("Su pelo negro y rizado olía intensamente a brillantina" (47)), sino que también, como en su infancia, el protagonista disfraza su habla. Marés se comunica principalmente en un castellano neutro, aunque a veces dice palabras en catalán; su discurso no se presenta tan localizado como el de Faneca, cuyo marcado acento del sur funciona como diferenciador social. La diferencia de hablas entre Marés y Faneca, y su habilidad para transicionar de una a otra con maestría, se observa sobre todo en los diálogos que el personaje tiene consigo mismo (es decir, los que tienen Marés y Faneca entre sí):

- ¿Sigues obsesionao con esa mujé?

-Sigo.

-Te conviene hacer una locura, Marés.

-No puede salir bien. No insistas.

-Saldrá bien. Debes creerme, malaje -dijo entre dientes [...]. Tú déjame hacer a mí, saborío. Hablaré con esa mujé, y esa mujé volverá a tus brazos. Lo juro por mis muertos. (47)

A veces, Marés sueña con Faneca, y ambos coexisten en el mismo espacio, como si fueran dos cuerpos diferentes. En los sueños de Marés, ambos tienen una vida propia y complementaria. El acordeonista callejero le comenta a su amigo Cuxot:

Soñé que entraba en mi cuarto y me llamaba a mí mismo por mi nombre. Era yo, pero casi no me reconozco. Yo estaba en la cama y al mismo tiempo estaba de pie en el umbral del dormitorio, vestido de chuloputas. Una pinta de charnego de caerse de espaldas. Pelo negro ensalivado, ojos verdes, patillas. Un moreno 
de verde oliva, oye. Un tipo de película, Cuxot. Me llamó cornudo. Dijo que se presentaría a Norma haciéndose pasar por un antiguo amigo mío del barrio [...]. Pero era yo mismo disfrazado de murciano chuleta y estaba allí de pie dándome la tabarra otra vez, proponiéndome una especie de broma, un plan para presentarse a mi ex mujer y ligársela de nuevo. (50)

El sistema pronominal, junto con las flexiones verbales, delatan la duplicación del personaje, que siempre asume la primera persona del singular. Así, el sujeto de "soñé" coincide con el de "llamaba", por ejemplo, y también coinciden con el objeto "me" y el posesivo "mi". En la oración coordinada con el nexo adversativo "pero" se hace visible la confusión de identidades. Sin embargo, en la simultaneidad configurada en la construcción adverbial "al mismo tiempo", que vincula dos circunstanciales de lugar ("en la cama" y "en el umbral del dormitorio") evidencian la separación de los individuos. Su postura corporal también es diferente: Marés se presenta sentado o acostado, mientras que Faneca lo hace "de pie". La mirada catalana de Marés recorta los aspectos más estereotípicos del Otro-Faneca, y destaca el significado vinculado con la oscuridad ("negro", "moreno"). En tanto catalán, Marés define al sureño con términos peyorativos, como "chuloputas" o "murciano chuleta" y pone de manifiesto su mirada prejuiciosa al referirse a su "pinta de charnego". En el adjetivo “disfrazado" se observa que Marés aún considera que Faneca es un disfraz, y todavía controla voluntariamente las dos identidades.

De hecho, en un principio, Marés se transforma en Faneca cuando lo desea. Sin embargo, a través de ciertas estrategias discursivas, Marsé comienza a dar algunas pistas sobre la futura superposición de identidades:

El día de su cita con Norma, viernes, Marés trabajó en la plaza del Pi de diez de la mañana a dos de la tarde [...]. Se sentó a la mesa y durante un buen rato estudió su cara reflejada en el espejo, una cara pálida y contrita, castigada por los años, la memoria amarga de un amor fracasado y el fogonazo intolerante de un cóctel Molotov-Tío Pepe. Cuántas cosas borradas en esta cara. Se miraba en el espejo fríamente, contemplando sin pena ni dolor el tipo ansioso y anodino 
en que se había convertido. Se llevó las manos a la cabeza, sin ánimo para nada. Su cabello blanquecino y escaso parecía muerto, de hecho no parecía cabello, sino más bien resecos mechones de alfombra [...].

-Incluso sin ponerte ninguna máscara -se dijo sin amargura - ¿quién sería capaz de reconocerte? ¿Quién podría identificar esta piltrafa anónima con aquel apuesto don nadie felizmente casado con Norma Valentí?

-Nadie -se contestó con la otra voz - Capullo [...].

En primer lugar se aplicó un maquillaje de fondo por toda la cara y las orejas utilizando una esponja humedecida con agua. Luego se ciñó la peluca negra y rizada y con la ayuda de almaste se pegó cuidadosamente las patillas y el bigote [...]. Poco a poco, detrás de la bruma herrumbrosa del espejo, apareció la cara del charnego soñado mirándole primero con recelo, después con una mueca irónica: un tipo agitanado y parsimonioso, arrogante, con un ojo tapado por el parche negro, el otro verde y pinturero [...]. Percibió como respuesta una leve sonrisa ladeada y observó que el sarcasmo y la maulería iban creciendo en el único ojo verde que lo miraba, pestañón e inquisitivo, y se levantó dispuesto a cambiarse de ropa $[. .$.$] .$

-Fabulozo - dijo con la voz de Faneca, y dio algunos pasos sin salirse del espejo. Forzando apenas las cuerdas vocales, perfeccionó la voz rota Probando, probando -dijo al espejo. -Uno, dos, uno, dos, probando la voz acharnegada y subyugante que ha de enamorar a mi mujer [...].

Y entonces, cuando ya dominaba plenamente la situación paseándose de un lado a otro por el cuarto, hizo dos cosas que no tenía previsto hacer, que nunca había pensado que iba a hacer y que en realidad no deseaba hacer, como si una voluntad ajena se hubiese apoderado de él: encendió un cigarrillo-él, que nunca había fumado, salvo cuando era un niño-y se cambió la corbata gris perla por otra granate con arabescos tornasolados, mucho más llamativa.

Parado ante el espejo, erguido y un poco de lado, la mano derecha en el bolsillo de la americana cruzada y la izquierda en alto sosteniendo el cigarrillo entre los dedos, el charnego Faneca le miraba detrás de las espirales de humo sonriendo aviesamente. $(140-44)^{71}$

La primera parte del fragmento citado se centra alrededor de la figura de Marés, quien asume la función de sujeto en la primera oración con su nombre. Este personaje se configura a partir de tres ideas principales, la primera es la de claridad, significado ya relevado para el universo de lo Propio catalán, y visible en adjetivos como "pálida" o "blanquecina". La segunda idea, también ya mencionada, ${ }^{72}$ es la de impotencia; el campo semántico que la delimita comprende adjetivos ("fracasado", “intolerante", "anodino") y estructuras

\footnotetext{
${ }^{71}$ Incluimos esta cita en toda su extensión debido a su productividad para el análisis textual.

${ }^{72}$ Sobre todo en la figura de Luis Trías, de Últimas tardes.
} 
preposicionales, como "sin ánimo para nada". La tercera idea a través de la que se estructura el personaje de Marés es la de la pena, visible en términos como "contrita", "castigada" y "amarga". El adjetivo "amarga" califica a la "memoria" y da cuenta de un pasado mejor, el contraste entre el presente penoso y el pasado idealizado cobra más fuerza en la primera línea de diálogo, en la que se presentan dos ideas contrapuestas, la de "piltrafa anónima"— término que subsume los significados de "pena" e "impotencia", y que describe el presente de Marésy la de "apuesto don nadie felizmente casado", de connotación positiva.

En el diálogo se observa la primera marca de transición, pues un Marés autovictimizante es respondido por "otra voz" con arrogancia, significado que ya hemos asignado al universo de lo Otro. Faneca surge, entonces, como "una voz", lo que, sumado a su acento, hace manifiesta la importancia del tema del habla en la novela. El diálogo opera, además, como un punto de inflexión, e inaugura una segunda parte, en la que se despliegan los conceptos vinculados con el universo migrante.

La segunda parte continúa las estructuras de sujeto tácito anteriores, lo que evidencia la gradualidad del proceso de transformación. En este mismo sentido, los roles de sujeto y objeto son asumidos por una tercera persona sin nombre, lo que suma ambigüedad al proceso, pues no es claro si el sujeto y el objeto son dos personas diferentes o la misma. En el fragmento “apareció la cara del charnego soñado mirándole primero con recelo, después con una mueca irónica" no solamente se observa la confusión de sujeto y objeto-adherido en forma de enclítico al gerundio "mirando"-, sino que también se evidencia una transformación en la mirada, primero recelosa (Propia) y luego arrogante (Otra).

Esta parte recupera dos significados relativos al ámbito migrante: el de lo oscuro, definido por los términos "peluca negra" y "parche negro", y el de la arrogancia, construido por los adjetivos "arrogante", “irónica", "parsimonioso", sustantivos como "sarcasmo" y construcciones como "leve sonrisa ladeada". El sustantivo "maulería" refiere muy sutilmente 
al significado de la estafa, también ya revisado. Además, en el adjetivo "agitanado" se observa el funcionamiento antinómico del dispositivo Propio/Otro, que hace difusa la diversidad que integra todo lo que no es Propio catalán.

La segunda intervención dialogada es asumida nuevamente por Marés, quien habla "con la voz de Faneca", lo que, sumado a la cláusula de gerundio "forzando apenas las cuerdas vocales", registra que Marés todavía es quien representa a Faneca. El hecho de que se refiera a Norma como "mi mujer" corrobora esta afirmación.

Sin embargo, el párrafo siguiente hace visible el proceso de superposición de identidades. Las primeras proposiciones incluidas, cuyo sujeto es el mismo sujeto tácito de la oración principal, pueden ser asumidas tanto por Marés como por Faneca. De este modo, cabe preguntar quién "dominaba plenamente la situación", y quién era el que caminaba frente al espejo. Más adelante, luego del núcleo verbal, la variedad de proposiciones incluidas gira alrededor de la idea de negación (no, nunca), lo que podría interpretarse como la anulación de una de las identidades. La estructura comparativa condicional "como si una voluntad ajena se hubiese apoderado de él" inclina la balanza a favor de Faneca, quien de hecho fuma y prefiere los colores estridentes. Ya en la última oración, el proceso de transformación parece haberse concluido, y Faneca asume el rol de sujeto de la oración.

Por último, cabe aclarar que la contraposición entre Marés y Faneca se hace manifiesta en dos puntos. Primero, en su actitud: Marés se auto-victimiza; ya hemos revisado la idea de impotencia y de pena. Faneca, por otra parte, se textualiza "sonriendo aviesamente", y en el gerundio se le otorga a su talante mayor continuidad. Además, se distinguen, como hemos visto, por su postura corporal; por un lado, Marés es retratado "sent[ado] a la mesa", mientras que Faneca se presenta "parado ante el espejo, erguido y un poco de lado".

Lentamente, Marés comienza a perder control sobre la situación; experimenta "la creciente sensación de que alguien que no era él lo suplantaba y decidía sus actos” (119), y la 
identidad de Faneca empieza a ahogarlo, se siente "agobiado por la máscara, [...] tironeado cada vez más por los hilos invisibles de una marioneta que empezaba a no controlar" (117-18). Faneca comienza a “ocuparlo", al punto de que comienza a cerrársele el ojo que Faneca esconde detrás del parche, "[tiene] mareos y se [le] olvidan las cosas" (174). Faneca y Marés comienzan a dejarse notas, como si fueran dos individuos escindidos que comparten el lugar en el que viven. Cuando Marés se presenta casi desdibujado, y Faneca ocupa el rol protagónico, se observa también un desplazamiento geográfico (King “Desempeñar” 80, Sotelo 390). Faneca alquila una habitación en la pensión Ynes y sólo regresa al Walden ocasionalmente. Para King, la decisión de Faneca de quedarse en la pensión se consolida como el fin del proceso en el que Faneca reemplaza a Marés (“Desempeñar” 81). En este sentido, la figura de Marés/Faneca comienza a aproximarse a uno de los tipos de doble definidos por Otto Rank, el que surge de "la representación, de una y la misma persona, de dos seres diferentes separados por amnesia" (20).

King observa también que "al igual que Marés no ha podido negar los aspectos 'castellanos' de su personalidad, Faneca no puede erradicar totalmente lo catalán de Marés” (81) y se refiere en este punto a la figura del Torero Enmascarado, disfraz con el cual se cierra la novela. El Torero Enmascarado es un personaje que había sido creado por Marés algunos años antes del surgimiento de Faneca y que este último recupera. Vestido con un traje de torero verde y dorado, Marés/Faneca encarna a este personaje que toca con su acordeón un "repertorio de sardanas y de canciones populares catalanas [...] infinito" (219) en la plaza de la Sagrada Familia. En primer término, se observa entonces la simultaneidad en la representación de elementos tradicionalmente asociados a lo sureño (la figura del Torero) con otros asociados a la catalanidad (la Sagrada Familia, la música tradicional catalana). El tema lingüístico se desarrollará con más profundidad en el próximo capítulo. Sin embargo, es relevante incluir en esta sección el monólogo del Torero, que responde de esta manera a la pregunta “De què se'n 
fot, vostè?” (“¿de qué se ríe usted?” en catalán) de un transeúnte “bajito y calvo, [...] con las manos en la espalda y media sonrisa acartonada de suficiencia" $(220)::^{73}$

-Pué mirizté, en pimé ugá me'n fotu e menda yaluego de to y de toos i així finson vostè vulgui poque nozotro lo mataore catalane volem toro catalane, digo, que menda s'integra en la Gran Encisera hata onde le dejan y hago con mi jeta lo que buenamente puedo, ora con la barretina ora con la montera, o zea que a mí me guta el mestizaje, zeñó, la barreja el combinao, en fin, s'acabat l'explicació i el bròquil, echusté una moneíta, joé, no sigui tan garrapo ni tan roñica, una pezetita, cony, azi me guta, rumbozo, vaya uzté con Dio i passiu-ho bé, senyor... (220)

El diálogo pone de manifiesto nuevamente la coincidencia simultánea, en el personaje del Torero/Marés/Faneca de los ámbitos de lo Otro y de lo Propio. A nivel lingüístico, la lengua catalana ("finson vosté vulgui”) se imbrica con la grafía fonética del acento andaluz (“en pimé ugá"), a lo que se suma un cierto castellano neutral ("lo que buenamente puedo"). La combinación de los dos ámbitos no se da solamente en el nivel de la lengua, sino también en el del significado. Así, la "Gran Encisera” convive con los "mataore”, al tiempo que la barretina lo hace con la montera, y la barreja con el combinao. ${ }^{74}$

Este discurso ha sido extensamente analizado por la crítica. King, en primer lugar, afirma que este monólogo representa "la imposibilidad de superar identidades opuestas y basadas en los tópicos y las caricaturas” (“Desempeñar” 82). En el mismo sentido, Forrest observa que, aunque esta figura promueve la diversidad étnica, no logra un mestizaje armónico entre la mayoría catalana y la minoría andaluza (51). Para Deiser, por otra parte, en el tejido de

\footnotetext{
${ }^{73}$ Sherzer apunta la similaridad entre este retrato y el de Jordi Pujol ("Juan Marsé's El Amante" 413)

${ }^{74}$ La "Gran Encisera" es el epíteto con el que el poeta modernista Joan Maragall se refiere a la ciudad en su "Nova oda a Barcelona", de 1909. El término "mataore" se aproxima a la pronunciación sureña de "matadores", plural del sustantivo definido por la RAE como "torero que por profesión ejerce el arte de matar los toros con la espada", lo que establece un vínculo con la tradición taurina, de fuerte raigambre en el sur español. La barretina es un gorro tradicional catalán, mientras que la montera es el sombrero típico del torero. La barreja es una bebida típica catalana, que consiste en la mezcla de un aguardiente (por lo general, anís) y un vino, que suele ser moscatel. El término también se utiliza de modo coloquial como sinónimo de "mezcla". El combinado es una bebida característica del sur de España, producto de la mezcla de un vino con una bebida gaseosa sin alcohol.
} 
elementos castellanos y catalanes que dan lugar a la figura del Torero hay una intención de presentarse como un multifacético artefacto cultural (75). Rubén Domínguez afirma que en este monólogo se evidencia la imposibilidad del monolingüismo: "Marés/Faneca/El torero enmascarado habla desde una posición marginal, luchando contra lo inteligible y lo monolingüe y enviando un mensaje de fragmentación cultural” (300).

Creemos que el fragmento citado es uno de los puntos de mayor relevancia en el que se observa la superposición de los ámbitos de lo Propio catalán y de lo Otro. El mensaje de hibridez se presenta desde varios frentes: por un lado, la figura del Torero frente a la Sagrada Familia tocando sardanas; por el otro, la combinación de lenguas y significados a los que ya nos hemos referido, que pone de manifiesto la factibilidad de la convivencia de hablas y significados asociados al espacio sureño y al catalán. Laura Connor afirma que el Torero habla "un lenguaje híbrido que nadie comprende" (11). Sin embargo, creemos que si bien el discurso no es absolutamente inteligible, sí lo es en su mayor parte, y vehiculiza ideas poderosas. ${ }^{75}$ Resalta, en primer lugar, la resistencia del espacio de lo Propio frente a lo Otro ("nosotros lo mataore catalane volem toro catalane"), al punto que hace visible las dificultades experimentadas por los inmigrantes frente a esta resistencia: "menda s'integra en la Gran Encisera hata onde le dejan". En este sentido, Sherzer observa que este mensaje es a la vez una petición por la integración social del migrante, y una normalización genuina de la cultura catalana a través de esta incorporación (“Juan Marsé’s El amante” 412). Presenta, finalmente, una apuesta por el mestizaje, que se alinea con la propia opinión de Marsé, quien sostiene que “el mestizaje cultural y lingüístico es positivo, es bueno siempre [...] a mí me parece uno de los

\footnotetext{
75 Transcribimos nuestra "traducción", marcando en bastardillas las expresiones provenientes del universo catalán y en negrita las del sureño: "Pues mire usted, en primer lugar me río y yo ya luego de todo y de todos, y así hasta donde usted quiera porque nosotros los matadores catalanes queremos toros catalanes, digo, que uno se integra en Barcelona hasta donde lo dejan, y hago con mi cara lo que buenamente puedo, ora con la barretina, ora con la montera, o sea que a mí me gusta el mestizaje, señor, la barreja, el combinado, en fin, sanseacabó. Eche usted una monedita, joder, no sea tan tacaño ni tan roñica, una pesetita, coño, así me gusta, generoso, vaya usted con Dios, y páselo bien señor..."
} 
inventos más buenos que existen" (Pérez 126-7). Esto ha sido interpretado por Connor como una afirmación irónica, pues "la coexistencia de dos lenguas, culturas e identidades en un cuerpo ha llevado a la destrucción de Marés/Faneca y ha producido la incomprensibilidad de Faneca" (12). Sin embargo, consideramos que en el Torero coexisten elementos de ambos universos, y, como hemos referido, no somos de la opinión de que este diálogo no sea comprensible: es, sin lugar a dudas, imbricado y complejo, lo que es compatible con una identidad que problematiza lo homogéneo y se estructura en las diversidades. Creemos que el discurso del Torero es eficaz, pues en su forma inestable, compatible con la lógica de la modernidad líquida, logra transmitir al mismo tiempo una realidad, un reclamo y una posibilidad nueva de nación para el caso catalán.

El discurso del Torero es simultáneamente catalán y sureño. No apunta a una síntesis uniforme, sino que presenta las tensiones propias de una escritura abierta y multiforme. Esa complejidad hace patente la idea de la diversidad posible de interpretaciones sobre todo discurso, lo que puede aplicarse también al que define una cierta idea de nación. El monólogo del torero se abre a la mezcla, y rehúye de las perspectivas homogeneizantes que obligan a tomar partido por una de las dos identidades. Al hacer confluir al mismo tiempo los espacios de lo Otro y lo de Propio catalán, y sin jerarquizar ninguno, el monólogo hace manifiesta la posibilidad de un espacio de hibridez, que desdibuja no solamente las definiciones hegemónicas de lo nacional catalán, sino también las fronteras fijas entre lo que se considera Propio y lo que no. El Torero Enmascarado encarna la posibilidad de la identidad dual en su persona, pero permite extender esta indefinición de fronteras al ámbito nacional de Cataluña. Como observa Kim: "Con este pasaje el autor abre un horizonte de esperanza; transmite el mensaje de que en una sociedad bilingüe todos deben disfrutar de la vida manteniendo su identidad personal" (371). 
La complejidad del discurso del Torero da cuenta de la movilidad histórica del concepto de nación, y promueve la idea de la comunidad nacional como una colectividad inestable, atravesada por lazos móviles y dinámicos, que rehúye de las clasificaciones estancas y se propone como una formación social, demográfica e identitaria que se reformula permanentemente a lo largo de la historia. La figura y el habla del Torero representan una idea nacional heteróclita, abierta y contrahegemónica de los relatos estancos y categorizadores. Es quizás el símbolo más cabal de la evolución del discurso nacional que sostenemos que dibuja Marsé en su novelística. Como observa Victoria Calmes, el yo fragmentado del Torero "supone una crítica de los rígidos estratos sociales y constituye una deconstrucción del orden social tradicionalmente establecido" (217).

King señala el juego que abre la última frase del monólogo del Torero, que es también la última frase de la novela ("vaya uzté con Dio i passi-ho bé, senyor"), que parece dirigirse tanto al peatón que le habla a Marés como al lector, que acaba de finalizar el libro. El crítico observa que el hecho de que se interpele al lector en dos lenguas es el signo más expreso de que el lector debe comprender la realidad catalana (y a veces, su lengua, ya que no hay notas al pie). Por otra parte, destaca King, la novela ganó el Premio Ateneo de Sevilla, lo cual prueba que el texto funciona en otros ámbitos más allá de Cataluña. Esto le permite afirmar:

Estas ambigüedades sirven para que la estructura del libro refleje su contenido; es decir, la novela juega con su propia identidad cultural de la misma manera que juega Marés/Faneca. Sin duda, la obra es un producto de la cultura catalana, pero no de la cultura monolingüe representada por Valls Verdú; es el producto de una cultura catalana heterogénea, o quizá sería mejor describirla como un producto de culturas catalanas. ("Desempeñar" 82)

De este modo, la novela en sí misma se erige como un elemento de cruce, híbrido, que se dirige a un lector cómplice de esa hibridez. El amante bilingüe genera significados adentro y afuera 
del espacio catalán, y hace visible un circuito de producción y recepción de literatura válido y legible en ambos espacios.

Otro de los medios a través de los cuales Marsé golpea al statu quo es el de la carnavalización, explícita e implícita. En primer lugar, El amante bilingüe textualiza la fiesta del carnaval, momento en el que, nuevamente, la identidad de Marés se multiplica. Para la fiesta del carnaval, Marés toma prestado el disfraz de su amigo Serafín, que a la vez ha elegido transformarse en un lustrabotas del que su prima Olga estuvo enamorada. Así, Marés disfrazado de Serafín disfrazado de lustrabotas se encuentra por casualidad con Norma y sus amigos. Ella ha decidido vestirse de "puta portuaria, de esas que en las películas francesas se apoyan en una farola con la falda de satín negro abierta en el costado y susurran chéri con la voz venérea y los ojos entornados por el humo del cigarrillo" (97). El disfraz de Norma también, entonces, se hace doble, pues se disfraza de una actriz que a su vez representa un personaje. Por otro lado, cabe aquí destacar que Norma vuelve a presentarse en relación con una lengua otra, diferente al castellano. Durante el carnaval, Marés/limpiabotas logra acercarse a Norma/puta portuaria y mantener un diálogo con ella, sin hacer manifiesta su identidad real. El diálogo entre Norma y Marés puede plantearse como un anticipo; la próxima vez que Marés logre dialogar con Norma será también detrás de una identidad-disfrazada, la de Faneca, a través de la que logrará seducirla. El carnaval suspende las normas y permite una forma diversa de organización social; pues como afirma Bajtin "es la vida misma la que interpreta y durante cierto tiempo el juego se transforma en vida real" (6). Marés puede acercase a Norma y dialogar con ella dentro de un ambiente de representación carnavalesca.

Ahora bien, como observan Marta Arana y Carolina Castillo, si la fiesta del carnaval presenta un orden otro en el transcurso del tiempo social, el discurso paródico también "se presenta como una forma de crítica sociocultural, como respuesta disidente frente a la 'palabraley', que pone de manifiesto la presencia de dos ideologías o discursos en pugna, los cuales se 
disputan un espacio de poder simbólico" (50). En este sentido, la ironía desplegada por Marsé sobre temas como la cuestión de la normalización lingüística consolida una escritura contestataria. El punto más fuerte quizás de esta crítica es el de la confusión de fronteras entre los espacios de lo Propio y de lo Otro; Arana y Castillo afirman que es característico del procedimiento paródico la recurrencia a estrategias de tipo especular, particularmente las duplicaciones (50). En este sentido, a través de la parodia y de la burla, Marsé afirma la flexibilidad de aquellas fronteras y su carácter de constructo.

Uno de los personajes a través de los cuales Marsé despliega con más fuerza su discurso parodizante es el de Griselda Ramos Gil. Vecina de Marés en el Walden 7, es la primera persona con la que Marés evalúa la eficacia de su "disfraz" de Faneca. Tiene éxito, pues Griselda—a quien su vecino catalán le resulta profundamente antipático—se siente atraída por Faneca. Hacia el final de su primer encuentro, también Marés/Faneca se siente cautivado por ella y terminan teniendo un encuentro sexual. Esta atracción funciona también como una marca incipiente del progresivo desarrollo del trastorno disociativo, pues "[n]unca le había gustado aquella mujer, y sin embargo se sentía atraído hacia ella por una fuerza extraña. Presentía confusamente que su papel era usurpado, que el que avanzaba hacia la señora Griselda era otro" (79).

El nombre de Griselda la excluye del ámbito de la catalanidad, y la configura como migrante. Algunos datos accesorios confirman esto, pues "tenía una hija de veinte años casada en Zaragoza con un carnicero" (76-77). Es un personaje esperpéntico y caricaturizado, de "manos gordezuelas", “ojos bovinos y enrojecidos" y "nalgas oscilantes", que prefiere que le llamen "Grise" porque "tiene un aire extranjero" (76-77). Su habitación "estaba decorada para que durmiera en ella no una viuda gorda y romántica sino una niña", pues el empapelado tenía dibujos "de elefantitos rosados, jirafas y cebras" y sobre la colcha celeste había un "gigantesco oso blanco de peluche" (78). Es notable, entonces, que el procedimiento paródico de la 
caricaturización se lleva a cabo a través de los recursos de la animalización y las referencias a la deformación corporal.

A pesar de su origen, Marés/Faneca sabe que la mujer "era muy catalanufa" (75) y formula una pregunta que da lugar a la ironía crítica de la voz autoral sobre el nacionalismo excluyente. Frente a la pregunta sobre si ella apoyaría una iniciativa del Parlament catalá para buscar el modo de que el tenor Josep Carreras no sea considerado en el mundo "una gloria de España, sino como un catalán universal” (75), Marsé le hace decir a Griselda: “-No necesito pensarlo. Mi respuesta es sí. Y más aún. Lo que deberían hacer el Carreras y la Caballé es cantar ópera en catalán. ¿No doblan las películas al catalán? Pues que doblen también las óperas. ¿No le parece que sería muy bonito?” (75). El discurso paródico se asienta, en este caso, en la hipérbole tanto del retrato del personaje como de su catalanidad.

En pleno momento histórico de normalización lingüística, Marsé se sirve del personaje de Griselda para ridiculizar las perspectivas homogeneizantes sobre el discurso nacional catalán. Este personaje establece vínculos con la larga tradición caricaturesca española y, en tanto caricatura, "pone en juego, ante todo, una mirada en negativo respecto a la representación oficial" (Patiño 221). La comicidad generada por la caricatura funciona como un mecanismo de trasgresión y banaliza la mirada homogeneizante del nacionalismo catalán, trivializando su poder político. Corroe de esta manera los cimientos de la antinomia Propio/Otro y la ridiculiza.

Finalmente, es necesario destacar que El amante bilingüe, publicada veinticuatro años más tarde que Últimas tardes con Teresa y veinte más tarde que La oscura historia de la prima Montse, inicia un nuevo ciclo de registro de la Otredad. Si la novela de 1966 configuraba un primer paso en el registro del migrante como nueva figura social, la de 1990 presenta una nueva oleada migratoria, y la incluye dentro de la sociedad contemporánea. Como indica Clua, en 1990 se inicia una segunda ola migratoria que se extiende durante el período 1990-2010. Según la antropóloga, sólo en los últimos diez años de ese período Cataluña recibió más de un millón 
de migrantes, provenientes esta vez de fuera de la comunidad europea, especialmente del norte de África, Sudamérica, China y Europa del Este (“Algunos factores” 68).

Al igual que en 1966, Marsé registra en su novela el arribo de estos nuevos sectores migrantes, esta vez más diversos y heterogéneos entre sí. Se refiere muy fugazmente, en primer lugar, a "los vagabundos y los camellos marroquíes y negros merodeando como de costumbre bajo los portales" (121). La asociación entre inmigración africana y delincuencia ya ha sido revisada por López, Cuadrado y Navas, quienes han llevado adelante un trabajo de campo para comprobar la potencia de los estereotipos a la hora de calificar distintos grupos sociales a través de distintas categorías, entre ellas, la moralidad. El estudio ha puesto de manifiesto que "los marroquíes, el grupo que tiende a generar una mayor amenaza exogrupal en España [es el de] los peor valorados en esta dimensión" (206). El estereotipo comprueba entonces la asociación entre Otredad y delincuencia, lo que recupera la misma vinculación para los sureños, representada por Manolo Reyes, en 1966.

Marsé también registra otro sector migrante, proveniente de Asia, al que también alude en pocas líneas. Cuando Marés/Faneca llega a la casa de Norma: "Una muchacha de rasgos asiáticos le esperaba en el porche manteniendo la puerta abierta [...]. Cruzaron el amplio vestíbulo y la criada filipina le condujo a una salita situada en el ala derecha de la torre, con altos ventanales que daban al jardín” (145-46). Como Maruja en 1966, la criada filipina se vincula con un trabajo no calificado. Nuevamente, la Otredad se textualiza en relación de dependencia con el ámbito de lo catalán: si Maruja llevaba a cabo las tareas domésticas de la casa de los Serrat, la criada filipina ahora se encarga de las de Valentí.

De este modo, El amante bilingüe se consolida como la última etapa en la configuración por Marsé de una nueva idea de nación para el caso catalán. No solamente cuestiona la inmovilidad de fronteras entre lo catalán y lo sureño, sino que la ridiculiza y la socava. Asimismo, hace coincidir los espacios migrantes y autóctonos en un mismo personaje, además 
de presentar otros profundamente atravesados por estas tensiones. Marés/Faneca, y, sobre todo, El Torero Enmascarado, dan cuenta de la posibilidad de habitar ambos espacios simultáneamente; y hacen factible la idea de la coexistencia dentro de una totalidad nacional. La mirada de la novela no es ingenua, y despliega los conflictos y las tensiones existentes en la interculturalidad, pero sugiere una posibilidad de convivencia heterogénea de diversidades, lo que es impensable dentro de la definición clásica de nación.

Por otra parte, El amante bilingüe inaugura también una nueva etapa de integración en su diferencia, al funcionar, nuevamente, como un registro de una segunda ola migratoria. La novela es en este punto un primer paso, un incipiente reconocimiento de una nueva forma de Otredad que busca un lugar en Cataluña. Tendrán que pasar quince años aún para que estas nuevas figuras migrantes se conviertan en personajes de peso en otra novela: Canciones de amor en Lolita's club (2005) presentará personajes sudamericanos y norafricanos de relevancia, poniendo a funcionar nuevamente la máquina ficcional para diseñar una idea de nación de bordes estallados.

Canciones de amor en Lolita's club reinicia la operatoria marseana de incorporación de la diferencia dentro del escenario nacional catalán. Nuevo registro de nuevas figuras migrantes, la novela recupera asimismo el tema de la dualidad. Sus protagonistas son dos hermanos gemelos catalanes: Raúl, un policía agresivo, separado de la fuerza por problemas de conducta, y Valentín, quien sufre una deficiencia mental y trabaja en un burdel como cocinero. Las prostitutas que viven en ese burdel provienen de América Latina-Colombia, Cuba, República Dominicana-y del norte de África. Una de las pocas críticas que observa este fenómeno, Maja Zovko, sólo se refiere a esta novela para ejemplificar "la ficcionalización del reciente proceso de inmigración en relación con diversas actividades delictivas" (6). Como Manolo en Últimas tardes, las prostitutas de Canciones de amor pertenecen a los sectores 
marginalizados de la sociedad, y se construyen como figuras estereotipadas, que oscilan "entre la víctima y el delincuente" (6).

En conclusión, la incorporación de las nuevas figuras migrantes en El amante bilingüe abre un nuevo proceso de resquebrajamiento de los discursos nacionales monolíticos. Hace, sin embargo, visibles las dificultades y las contradicciones propias que subyacen a esta posibilidad a través de significados asociados a la locura y a la mendicidad, pero no deja de lado la idea de superposición y de coexistencia. Hace estallar los bordes fijos que separan lo Propio de lo Otro, y redefine el concepto de nación, ahora heterogéneo y flexible.

Revisadas ya las tres novelas que estructuran esta tesis, el próximo capítulo se abocará al análisis de la lengua literaria de Marsé. Consideramos que su opción por una variedad localizada del castellano, influida por la lengua catalana, prefigura la estrategia lingüística que subyace a toda su obra. En la selección de un determinado vocabulario y de ciertas estructuras gramaticales que evidencian la interferencia de la lengua catalana en el castellano particular de Cataluña, se vehiculiza asimismo la posibilidad de cruce y de mutua interpenetración. El capítulo quinto de esta tesis se abocará al análisis lingüístico de una lengua que hace evidente en su propia materialidad lo difuso de los bordes entre lo catalán y lo castellano. 


\section{Capítulo 5}

\section{Nación abierta, lenguaje híbrido: la estrategia lingüística de Marsé}

La situación lingüística de Cataluña configura un caso particular, pues en su territorio existen dos lenguas oficiales. El estatuto de autonomía catalán establece que: "La lengua propia de Cataluña es el catalán”, aunque inmediatamente después instaura: "El catalán es la lengua oficial de Cataluña. También lo es el castellano, que es la lengua oficial del Estado español. Todas las personas tienen derecho a utilizar las dos lenguas oficiales y los ciudadanos de Cataluña el derecho y el deber de conocerlas". El estatuto hace propia una de las dos lenguas que se hablan en la región, aunque oficializa ambas. Este capítulo se detendrá en la cuestión lingüística, esencial en los discursos identitarios, y problematizará las concepciones nacionalistas - en términos modernos - sobre la lengua. Revisaremos distintos conceptos sociolingüísticos vinculados con estas cuestiones para detenernos en el análisis de la lengua literaria de Marsé, estudio que no se ha llevado a cabo aún con este nivel de profundidad. Se fundamentará, a través de un análisis textual específico, que esta lengua literaria hace propias las dos lenguas oficiales de Cataluña, a través del uso de un castellano particular, específico de la región geográfica en la que se afinca, visiblemente interferido a nivel léxico, morfosintáctico y semántico por el catalán. La opción por esta lengua literaria híbrida constituye lo que hemos denominado estrategia lingüística, transversal a las tres novelas analizadas, y extensible a toda la obra de Marsé. Debido al carácter conceptual de esta estrategia, el marco teórico expuesto será un poco más extenso que en los capítulos anteriores.

El catalán es una lengua latina que se desarrolló originalmente en un territorio pequeño al este de los Pirineos. Al igual que todas las lenguas romances, la catalana surge luego de una larga evolución del latín. Es una lengua “iberorrománic[a] por su formación y se relaciona 
particularmente con las lenguas de este subgrupo por su morfología (flexiones nominal y verbal); sin embargo, el latín del que procede es más afín al latín de la Galia, lo que lo hace partícipe también de ciertos rasgos galorrománicos, especialmente en lo que respecta a su fonetismo y a buena parte de su vocabulario" (Vallverdú El conflicto 37). Ramón Menéndez Pidal, por su parte, coincide con Vallverdú en el origen ibérico de la lengua, y añade que, una vez consolidada en la península, pasó hacia los Pirineos por razones políticas. Menéndez Pidal agrega que los límites lingüísticos entre el aragonés y el catalán divergen hacia el norte, aunque al sur de Benabarre son coincidentes, lo que comprueba su filiación (ctd en Griera 77-78). Como afirma Elber Aguilar, según esta teoría, el catalán “era una modalidad más de los dialectos hablados en el siglo X en la península, donde formaban un continuum desde Galicia hasta Cataluña. Posteriormente, con la imposición de la Marca Hispánica por Carlomagno, el idioma influyó en otras zonas a las que no había tenido acceso con anterioridad y estrechó relaciones con las lenguas d'Oil a las que accedió" (98).

Su desarrollo y expansión se relaciona entonces con la evolución histórica de la denominada "Marca Hispánica". En esta zona se extendían los condados carolingios establecidos entre el 759 y el 801 de nuestra era aproximadamente en tierras de lo que hoy se conoce como Cataluña Vieja (esto es, la zona comprendida al norte del río Llobregat). Con la muerte de Wilfredo el Velloso, conde de Barcelona, en 897-a quien, según Vallverdú, la leyenda le atribuye la independencia de Cataluña respecto a la monarquía de los francos—, se produjo la división de sus dominios entre sus tres hijos. Los tres territorios generados por esta división patrimonial concuerdan con los tres importantes dialectos del catalán moderno: el central, el pirenaico occidental y el oriental (Vallverdú El conflicto 38).

Los comienzos de la situación de bilingüismo en Cataluña—problematizaremos este concepto más adelante — se remontan al siglo XV, cuando la dinastía castellana de los Trastámaras asciende al trono de la corona de Aragón en 1412, en el marco del Compromiso 
de Caspe, luego de una guerra civil. Como indica King, los Trastámaras conservaron la cooficialidad de las dos lenguas (catalán y aragonés), aunque “empezó a notarse un leve proceso de castellanización durante el reinado de esa dinastía. Este inicio cobró fuerza en 1469 con la unión de los Reyes Católicos, pero sólo llegó a consolidarse, según Martí de Riquer y Jordi Rubió, con la política castellanocéntrica de la dinastía de los Austrias, en particular durante los reinados de Carlos V y Felipe II" (Escribir 41). Los trabajos historiográficos sobre la situación lingüística a partir del siglo XVI abundan; Vallverdú registra que, por lo menos a partir del siglo XVI, la historia de la lengua catalana puede sintetizarse en un conflicto entre un proceso de sustitución lingüística a favor del castellano (o del francés en el caso del Rosellón) y un relativo proceso de normalización lingüística a favor del catalán (El conflicto 62). Entre otros, algunos factores que contribuyeron a este proceso fueron el traslado de la corte a Castilla, y la fuerte presencia del castellano en la Iglesia católica, lo que, como indica King, operó en dos direcciones. En primer lugar, a través de la presencia de funcionarios del clero castellanohablantes en monasterios y conventos catalanes, y, en segundo término, debido a la diseminación de manuales y libros religiosos escritos en lengua castellana (Escribir 43).

Esta situación se pronuncia a partir del Decreto de Nueva Planta de Cataluña, al que ya nos hemos referido en este trabajo. A través de esta cédula real, promulgada por Felipe $\mathrm{V}$ en enero de 1716, fueron abolidas las leyes e instituciones del Principado de Cataluña, que dejó de existir como tal y pasó a ser una provincia de la monarquía central. El Decreto de Nueva Planta estableció que las causas de la Real Audiencia se resolvieran en castellano-y no en latín, como se hacía hasta entonces-y asignó el castellano como única lengua administrativa. La imposición de la lengua castellana en la región fue profundizándose a través de diversos documentos, como la Real Cédula de Aranjuez (1768), que estableció el castellano como lengua obligatoria en los juzgados, en la enseñanza y en la curia diocesana. A fines del siglo XVIII, se promulgaron varias ordenanzas que oficializaron el uso del castellano en la región: 
se exigía el uso de esta lengua (o del latín) entre los escolapios, "so pena de pan y agua” (1775), que se lleven los registros del Gremio de Vara de Valencia en castellano (1764) además de los libros de contabilidad (1772), que la Universidad de Cervera no edite libros didácticos en catalán (1773), y que la enseñanza sea en castellano y según las normas de la Academia Española (1780) (Veny 339).

Estos decretos operaron en detrimento del prestigio de la lengua catalana: como observa Vallverdú, si bien las primeras letras se aprendían en catalán en escuelas parroquiales, la enseñanza media y superior, más acreditada, se castellanizó pronto: en 1764, la Real Academia de Ciencias y Artes de Barcelona reglamentó el castellano como lengua obligatoria ( $E l$ conflicto 69). El creciente prestigio del castellano en Cataluña tuvo un impacto en la prensa: los periódicos y proclamas comenzaron a publicarse en castellano de forma general. Hacia fines del siglo XVIII, el castellano era la lengua utilizada en prácticamente todos los registros escritos en Cataluña. Sin embargo, el catalán conservaba su lugar predominante a nivel oral. El analfabetismo de muchas áreas rurales contribuyó al uso casi exclusivo del catalán en estas regiones.

Nos hemos referido también al resurgimiento de la cultura catalana durante la segunda mitad del siglo XIX y principios del siglo XX, a través del movimiento cultural y literario conocido como la Renaixença. Durante este período también se revalorizó el uso del catalán, que trascendió el ámbito de la oralidad; no sólo se escribieron numerosos textos literarios y políticos en catalán, sino también surgieron instituciones vinculadas con la promoción de la lengua: en 1907 se fundó el Institut d'Estudis Catalans, y en 1911, su Sección Filológica. En 1913, el Institut publicó las Normas Ortográficas elaboradas principalmente por Pompeu Fabra. Fabra ya había publicado, en 1912, la Gramática de la lengua catalana (en castellano), que fijó los cimientos de su trabajo posterior, la Gramàtica catalana (1918, en catalán), de carácter normativo. El texto de 1918 fue adoptado por el Institut como normativa oficial. En 
1932, Fabra publicó su Diccionari general de la llengua catalana, que implicó la primera codificación léxica de la lengua (Veny 341).

Sin embargo, el resurgimiento de la lengua catalana se vio interrumpido primero por la dictadura de Primo de Rivera (1923-1930), que intentó reducir su uso al ámbito folclórico; y luego por la de Franco (1939-1975) que nuevamente pretendió establecer el castellano como lengua única en la región:

El triunfo del franquismo conllevó la abolición del Estatut d'Autonomia y la conculcación de anteriores derechos, como el de la lengua propia, barrida de la escuela, la justicia, los medios de comunicación, etc. durante aquellos cuarenta años, continuó el uso social del catalán entre la gente del país, pero, carente de escolarización y de canales mediáticos, le faltaba el uso formal, practicado sólo por grupos de militantes y autodidactas; su bilingüismo era general. Por otra parte, el impacto masivo de la inmigración provocó un alto porcentaje de castellanohablantes que, faltos de medios para el conocimiento de la lengua del país de recepción, continuaron en su mayoría monolingües. (Veny 340-41)

La represión de la lengua catalana a lo largo del franquismo vio diversas etapas: al principio, la persecución de la lengua y la cultura catalanas fue mucho más implacable que durante la segunda mitad de la dictadura, más flexible y abierta a la negociación. Sin embargo, el franquismo limitó el uso del catalán, que quedó definitivamente relegado al espacio doméstico. Por otra parte, el régimen impuso la castellanización de la zona, sirviéndose principalmente del sistema educativo y de los medios masivos de comunicación como instrumentos. Gran parte de los catalanes nacidos - o educados_-durante los cuarenta años de franquismo estuvieron sometidos a influencias exclusivamente en lengua castellana en la escuela, la radio, la televisión y el cine durante gran parte de sus vidas. Marsé fue uno de ellos, y, como hemos revisado anteriormente en este trabajo, sostiene que su elección del castellano como lengua literaria se asocia con sus influencias en este sentido: hasta 1975, circulaban pocos textos en catalán. 
La ola migratoria proveniente del sur que hemos referido en esta investigación incrementó la población de Cataluña significativamente, asentándose especialmente en la periferia de los centros urbanos como Barcelona. Este grupo migrante era castellanohablante, y aunque muchos autores ${ }^{76}$ subrayan el interés que este segmento poblacional mostraba por aprender el catalán, la coyuntura histórica no les era favorable para la adquisición de la lengua. De este modo, el arribo de esta enorme masa migrante contribuyó también a la castellanización de la región. De hecho, cierto sector de la historiografía catalanista considera a este grupo "una grave amenaza para la integridad de todo el cuerpo social" (Badia "Lenguas" 116). Como observa King, “en un país donde la lengua autóctona era casi la única seña de identidad, el castellano logró ser la principal lengua de comunicación” (Escribir 2).

Todos estos factores trajeron como consecuencia el hecho de que, para 1981 — fecha en la que Vallverdú publica su libro $E l$ conflicto-hubiera en Cataluña dos grupos lingüísticamente bien diferenciados. Por un lado, existía un sector que Vallverdú denomina “catalanohablante". Sin embargo, al especificar las características de este grupo, el lingüista afirma que "técnicamente, este grupo es bilingüe pues, aparte de su lengua habitual, conoce también el castellano" (148). Esta afirmación confirma que los términos "catalanohablante" y "bilingüe catalán-castellano" son-por lo menos dentro del pensamiento de uno de los máximos exponentes de la sociolingüística catalana-equivalentes. Dentro del grupo demográfico denominado "catalanohablante" (aunque es, como afirmamos, bilingüe), Vallverdú registra diferentes niveles de competencia en el uso de las dos lenguas. Por otro lado, afirma que existe en Cataluña otro grupo, el no catalanohablante, que puede a su vez dividirse en varios subgrupos de acuerdo a las lenguas habladas. Sin embargo, debido a la rotunda mayoría de hablantes de castellano que integran este segmento - un 90\% en Barcelona según Vallverdú—puede simplificarse "aplicando el nombre de castellanohablante” (149).

\footnotetext{
${ }^{76}$ Vallverdú, Badia i Margarit, Balcells.
} 
Las proporciones de estos dos grupos se han modificado desde 1981 a esta parte. El proceso de restauración de la lengua y cultura catalanas llevado a cabo por el gobierno autonómico después de la muerte de Franco extendió notablemente el grupo poblacional bilingüe. En este proceso, la Generalitat estableció dos objetivos básicos: en primer lugar, restaurar la lengua catalana al lugar que afirmaba le correspondía; en segundo término, se apuntó a la asimilación cultural y lingüística de la población inmigrante castellanohablante (Barrera "Lengua" 122). En 1978, se publicó el Decret del Català, que introdujo la asignatura de lengua catalana en las escuelas, y en 1983 se promulgó la Ley de Normalización Lingüística, que promovió el uso de la lengua catalana en diversos ámbitos: se la estableció como lengua vehicular de la enseñanza y se fomentó el uso del catalán en los medios de comunicación. Los esfuerzos sostenidos por la Generalitat han logrado resultados extraordinarios: el 93,8\% de la población entiende catalán, el 75,6\% lo sabe hablar, el 73\% lo sabe leer y el 56,6\% lo sabe escribir. $^{77}$ Considerando la equivalencia entre catalanohablantes y bilingües referida anteriormente, estos datos confirman que la mayoría de la población de Cataluña se desenvuelve en castellano y en catalán sin mayores dificultades.

Hemos visto, entonces, que "el castellano tiene una historia larga en la sociedad catalana, en la que está muy arraigado. Constituye, junto con la lengua catalana, un medio de expresión de la cultura e identidad catalanas, sea de los autóctonos, sea de inmigrantes o sus descendientes que se sienten catalanes y participan de la producción cultural catalana" (Sinner 122). Podría entonces considerarse, como hemos referido, que el grupo catalanohablante es un grupo bilingüe. La noción de "bilingüe" presenta, sin embargo, algunos puntos críticos que es necesario problematizar. Peter Hornby resume algunos de estos puntos y afirma que, para ser considerada bilingüe, una persona debe "tener la habilidad de usar dos lenguas diferentes" (1), lo que sería compatible con el grupo poblacional referido. Sin embargo, esta definición deja

\footnotetext{
${ }^{77}$ Datos de 2007, Instituto Estadístico de Cataluña, disponible en: https://www.idescat.cat/pub/?id=ed
} 
abiertos algunos interrogantes teóricos, y es poco precisa. Como señala Hornby, Leonard Bloomfield plantea la necesidad de aplicar el término sólo a quienes manejen dos lenguas con la competencia de un nativo; mientras que Einar Haugen, por ejemplo, considera que el bilingüismo debería caracterizarse desde ciertos estándares mínimos de uso de la lengua. Miguel Siguán apunta, por su parte, que entender el bilingüismo a partir de una competencia nativa en ambas lenguas es una definición ideal, y agrega que "en la práctica, lo que encontramos son individuos más o menos bilingües" (Bilingualism 34). Uriel Weinreich, por otro lado, define bilingüismo como "la práctica de usar alternativamente dos lenguas" (1). Coincidimos en la idealidad del bilingüismo absoluto, y creemos que las personas bilingües tienden a ese absoluto con distintos niveles de aproximación en su práctica cotidiana. Todas estas definiciones son aplicables al caso de los hablantes de castellano y catalán en Cataluña. ${ }^{78}$ Weinreich observa que el bilingüismo extendido es producto de una situación social en la que dos lenguas se presentan en contacto. Como registra Li Wei, este contacto suele ser impuesto por las circunstancias, mientras que los factores que contribuyen a esta situación son, entre otros, el sistema educativo, la economía, la religión o diversas situaciones de índole política (1). Todos estos factores contribuyen, o han contribuido, a la situación lingüística en Cataluña. Como analiza Georg Kremnitz, el bilingüismo puede ser un fenómeno individual o social (72), lo que también ha sido respaldado por el catalán Antoni Badia i Margarit, que se refiere a éstos como bilingüismo "natural" o "ambiental". Para Badia, el bilingüismo natural es, por ejemplo, el que resulta de tener padres hablantes de lenguas diversas; el bilingüismo ambiental es, por otra parte, el que suele darse en el caso de "lenguas minoritarias" que conviven con una lengua estatal diferente, como Badia cree que es el caso catalán (Llengua 136-37). Ahora bien, en los casos en los que el bilingüismo se presenta como un fenómeno

\footnotetext{
${ }^{78}$ Otros puntos críticos del concepto de bilingüismo, de menor relevancia para esta tesis, se vinculan con definir qué son, en realidad, dos lenguas (pues hay casos en los que los límites entre lenguas son borrosos, como indica Hornby [4]), o dilucidar si un bilingüe cuenta con dos sistemas semánticos distintos, o uno solo con dos formas de expresión para un mismo sistema de significados.
} 
social—como en Cataluña-deben considerarse los vectores sociales y políticos que rodean al fenómeno.

La coexistencia del catalán y el castellano en Cataluña es, para algunos, conflictiva. Como indica Joshua Fishman, las sociedades en las que el bilingüismo se encuentra muy extendido suelen moverse hacia la diglosia ("Bilingualism" 23). En un principio, el Grup Català de Sociolingüística ${ }^{79}$ definió este vínculo como diglósico, aunque más tarde problematizó el concepto. Como ya hemos referido, la diglosia ha sido definida por Charles Ferguson como:

[u]na situación lingüística relativamente estable en la cual, además de los dialectos primarios de la lengua [...], hay una variedad superpuesta, muy divergente, altamente codificada [...], vehículo de una considerable parte de la literatura escrita, ya sea de un período anterior o perteneciente a otra comunidad lingüística, que se aprende en su mayor parte a través de una enseñanza formal y se usa en forma oral o escrita para muchos fines formales, pero que no es empleada por ningún sector de la comunidad para la conversación ordinaria. (255)

Define a estas dos variedades como Alta (A, la de mayor prestigio) y Baja (B). Más adelante, Fishman extiende el concepto de diglosia y lo asume como fenómeno social, frente al bilingüismo que es, para él, un fenómeno individual y por lo tanto su estudio corresponde a la psicolingüística. Fishman amplía además la definición de diglosia a cualquier situación en la que existe una distribución funcional de dos variedades lingüísticas dentro de una comunidadya sean dialectos, sociolectos, registros de una misma lengua o dos lenguas distintas. Esta concepción de diglosia (“diglosia amplia”) se aproxima más a la situación catalana hasta el advenimiento de la democracia, en la que el castellano ocupaba un rol preponderante en las

\footnotetext{
79 Asociación científica fundada en 1973 por intelectuales catalanes procedentes de ámbitos diversos, fundamentalmente académicos. Algunos de sus representantes son A. M. Badia i Margarit, F. Vallverdú y Ll. Aracil.
} 
áreas administrativas y burocráticas (lengua A), mientras que el catalán había sido relegado al espacio doméstico (lengua B).

Sin embargo, si bien estos conceptos contribuyen al análisis de esta situación específica, no resultan completamente efectivos para tal propósito. Kremnitz observa que las miradas de Ferguson y Fishman plantean un fenómeno social en el vacío, que en el plano real, se da en una sociedad concreta. De este modo, al referirse a la diferencia de prestigio entre la variante o lengua A y la B, se deja de lado el hecho de que este prestigio es también social; por ello, prefiere hablar de "lengua dominante" y de "lengua dominada" (65). En esta misma dirección, el Grup Català de Sociolingüística reflexiona sobre la situación de estabilidad que refieren Ferguson y Fishman ("lenguas en contacto") y la reformula a través de la idea de "lenguas en conflicto". Vallverdú apunta que la sociedad catalana, hasta 1978, se caracteriza por exhibir un conflicto lingüístico caracterizado por "la confrontación entre una lengua dominante (es decir, una lengua políticamente privilegiada, oficial: el castellano) y una lengua dominada (es decir, una lengua políticamente discriminada, no oficial: el catalán)” (El conflicto 109). Rafael Ninyoles se refiere a las formas en las que la lengua dominante se impone sobre la dominada, y sostiene que éstas pueden ser claramente represivas (como, afirma, "las practicadas por el estado español durante el franquismo”) o bien las que son políticamente más tolerantes, pues aplican su poder a nivel ideológico (ejemplos de esto son el estado francés e italiano). Añade que el conflicto lingüístico puede presentarse de modo latente o agudo, según las condiciones socioculturales y políticas de cada sociedad (Conflicte 74). Lluis Aracil, por su parte, nota que suele explicarse el retroceso o la extinción de ciertas lenguas en estos contextos a partir de una mirada simplista, que considera que algunas son naturalmente "superiores o victoriosas", mientras que otras son inferiores, y tienen "defectos intrínsecos" (2). Afirma: "Estas mistificaciones sirven para 'explicar' (léase 'justificar') ideológicamente, por ejemplo, las ‘victorias' del francés sobre el bretón, o del español (léase el castellano) sobre el catalán” (2). 
Aracil construye un modelo teórico que se nutre de la cibernética para explicar la relación dialéctica que se da en los procesos sociolingüísticos. Este modelo inspira el trabajo de Ninyoles, que asevera que, para que la situación de conflicto lingüístico se transforme de latente a aguda, es decir, para que "las diferencias de lengua se conviertan en un factor de conflicto y lleguen a traducirse en una explícita actitud política" deben coincidir una serie de circunstancias políticas, sociales y culturales (Estructura 65). Afirma, entonces, que el conflicto lingüístico no es estrictamente lingüístico, sino social: “'las lenguas’ ni luchan ni colisionan: son los grupos de idioma los que entran en una relación cooperativa o antagónica" (Estructura 67).

Para Ninyoles y para los integrantes del Grup, en los territorios bilingües el conflicto siempre existe, ya sea latente o manifiesto. Coinciden en el planteo de que los términos últimos de ese conflicto son "la asimilación jerárquica al grupo lingüístico en posición ventajosa o la ‘normalización lingüística'” (Ninyoles Estructura 69). Kremnitz lleva esto más lejos al afirmar: "una diglosia o multiglosia relativamente estable, en la que cada lengua cumple su función, se moverá, tarde o temprano, a la eliminación de una de las lenguas de esa sociedad. Esto traerá como consecuencia o bien la normalización de la lengua dominada, que se emancipará y hará desaparecer a la lengua previamente dominante, o bien la sustitución de la lengua dominada por la dominante" (67).

El trabajo del Grup se integra en el contexto histórico de la dictadura franquista, cuya represión a las lenguas y culturas no castellanas excedía el ámbito de lo puramente lingüístico. Es comprensible, entonces, que dentro de este marco político se viera como única alternativa posible la eliminación de una de las dos lenguas de uso en Cataluña. Sin embargo, a pesar de las Leyes de Normalización Lingüística organizadas por el gobierno autonómico, tanto el castellano como el catalán siguen siendo utilizados por su población. Dado que tanto el concepto de diglosia, como el de bilingüismo social se apoyan en la idea de "comunidad de 
habla", se torna necesaria una revisión de la evolución del término, eficaz para aprehender estos fenómenos específicos.

Uno de los primeros lingüistas en estudiar el concepto de "comunidad de habla" fue Bloomfield, quien, en 1933, lo definió como "un grupo de personas que interactúa a través del discurso" (42). En un principio, esta definición se tornó más excluyente. John Lyons, por ejemplo, afirma que una comunidad de habla implica a "todas las personas que usan una lengua o dialecto dado" (326), mientras que, como registra Vallverdú, Michael Halliday y otros definían el término como "un grupo de gente que se considera que usa la misma lengua" ( $E l$ fet 17).

Sin embargo, después de 1970, estas concepciones fueron flexibilizándose, en un contexto histórico de mayor movilidad de lenguas y de personas. Así, Fishman afirma, en 1971, que en este tipo de comunidades "todos sus miembros comparten al menos una variedad de lengua (speech variety) y las normas para su uso apropiado" (Sociolinguistics 28). También en 1971, John Gumperz incorpora ya explícitamente la idea de que una comunidad de habla puede compartir el uso de más de una lengua, y sostiene que este tipo de comunidad es "un grupo social que puede ser tanto monolingüe como multilingüe, aglutinado por la frecuencia de la estructura de las interacciones sociales" (101). Esto concuerda con la perspectiva de Alan Hudson, quien afirma: "En el caso de la diglosia, me parece que, en último término, estamos frente a una sola comunidad de habla" (157). Carsten Sinner observa que esta definición permite pensar en la integración de individuos "que comparten las mismas normas lingüísticas sin que el grupo necesariamente hable una sola lengua", por lo que considera que puede aplicarse para lo que denomina "las sociedades bilingües españolas" (123). Con el fin de hacer expresa esta flexibilidad del término, Sinner propone reemplazar el término "comunidad de habla" por el de "comunidad de comunicación" o "comunidad comunicativa", lo que comprende "la totalidad de hablantes que participan activa o pasivamente en los circuitos 
comunicativos existentes en un determinado lugar en un determinado momento, indiferentemente de la lengua (o lenguas) que hable cada individuo e indiferentemente de las variables extralingüísticas" (124). Podemos plantear, entonces, que la comunidad de habla en Cataluña "es básicamente una comunidad de consenso, de sintonía, entre grupos e individuos diferentes, donde el conflicto está minimizado" (Moreno Fernández 20).

De este modo, frente a la mirada apocalíptica del Grup, puede plantearse también la posibilidad de la supervivencia de las dos lenguas en contacto en una misma comunidad. Estas dos lenguas se encuentran en una interrelación permanente, y de este intercambio surgen variantes específicas a nivel local: el catalán de Cataluña, por ejemplo, evidencia transformaciones propias de su relación con el castellano que no se presentan en el del Rosellón; mientras que, por otra parte, el castellano que se habla en este ámbito específico también manifiesta particularidades que son fruto de la interpenetración con el catalán. Nos referiremos a estos fenómenos más adelante en este capítulo.

Hemos referido que el análisis sociolingüístico del Grup se integra en un contexto histórico específico de represión a la cultura catalana. El conflicto de lenguas se torna entonces sinécdoque de un conflicto de poder, en el que se disputa la institucionalización y legitimación de una sola lengua. Sin embargo, la idea de que existe una sola lengua válida para construir un discurso nacional enraíza en las concepciones iluministas del concepto de nación, del que consideramos que Marsé toma distancia para dar lugar a otro más abierto a la diversidad. El Grup da por sentado que a cada nación le corresponde una-y sólo una-lengua, y enmarca sus estudios lingüísticos en esta asunción. Así, Vallverdú afirma: "La lengua catalana no es solo un medio de expresión, sino un medio concreto en el cual se articula, en el plano comunicativo, la vida colectiva. A través de la lengua se establece la identidad nacional, se expresa la pertenencia a una cultura diferenciada, se participa en unos sentimientos que concuerdan con los demás" (El conflicto 165). Sin embargo, como indica King, optar por el 
castellano-que forma parte del escenario lingüístico de Cataluña desde la Edad Media tardía — no fue fuente de conflicto hasta el siglo XIX, cuando surge con la Renaixença la idea de que la identidad nacional se basaba exclusivamente en la lengua catalana (Escribir 45).

La mirada nacionalista sobre la lengua no se abre a la posibilidad de que una nación pueda hacer propias dos lenguas. En esta dirección, Alexander Von Humboldt asevera en 1797: “Absolutamente nada es tan importante para la cultura de una nación como su lengua". Johann Herder, en 1772, se había preguntado: “¿Tiene una nación algo más precioso que su lengua?”, mientras que Thomas Davies, en 1843, ratifica: "Un pueblo sin una lengua propia es sólo media nación" (ctds en Edwards 2). Esta perspectiva nacionalista sobre la lengua llega al siglo XX, en el que Elie Kedourie asume que "un grupo que habla la misma lengua se conoce como nación, y una nación debería constituir un estado" (68). William Safran, por su parte, resalta la función instrumental de la lengua (única) en los discursos identitarios nacionalistas, y asegura que protege "la identidad colectiva y la cohesión comunitaria" (80). De este modo, se observa que las mismas líneas ideológicas, propias de la configuración del concepto de nación acuñada por el iluminismo que ya hemos relevado en este trabajo, subyacen a la idea monolítica que presupone que a una nación le corresponde una (sola) lengua. Consideramos que, a pesar de sus múltiples diferencias de acción, esta perspectiva atraviesa tanto al pensamiento del régimen franquista (que impone la idea de una España homogénea, con una lengua única, el castellano) como al nacionalismo catalán (que plantea, a su vez, una Cataluña unívoca, monolingüe y catalanohablante).

Weinreich registra los vínculos entre nacionalismo y lengua y considera que la sociolingüística debería describir un fenómeno que se corresponda con el concepto de lenguaje del mismo modo que se corresponden los términos "nacionalismo" y "nacionalidad". Propone la idea de "lealtad de lengua" (language loyalty) y explica: 
La lealtad de lengua, como el nacionalismo, designaría un estado mental en el que la lengua (como la nacionalidad), como entidad intacta y en contraste con otras lenguas, asume una posición alta en una escala de valores, una posición que debe ser "defendida". La lealtad de lengua, como el nacionalismo, puede ser la idea principal que llena la mente y el corazón de una persona con nuevos pensamientos y sentimientos y lo lleva a la acción organizada. (99)

De este modo, se observa que la idea de lengua única como sinécdoque de la nación opera en sintonía con el nacionalismo clásico. La rigidez que esa idea de nación imprime a sus fronteras es coherente con una idea lingüística monolingüe y homogénea, impermeable a la diversidad. Los nacionalismos (español y catalán) presentan el panorama lingüístico de Cataluña como un campo en el que dos lenguas "oficiales" están en pugna. Para esta mirada, el castellano y el catalán—en realidad, sus representantes—se disputan el lugar de autoridad. Sin embargo, como registra Smith, "la lengua introduce una dimensión de identificación y de comunidad nueva y poderosa, pero también se torna una barrera para la movilidad" (The Ethnic 220). Esta mirada habilita un planteo de la lengua única como mecanismo de exclusión: si la única lengua de Cataluña es el catalán, todos los castellanohablantes que habitan en su territorio quedarían por fuera de los bordes de la comunidad nacional. Los términos de Propio y Otro vuelven a resultar productivos para el análisis de esta situación en términos clásicos. Como registra King, el discurso nacionalista de la Renaixença funda una idea de nación catalana que se estructura "en el rechazo de los elementos considerados ajenos a la cultura catalana que habrían distanciado a los catalanes de su estado original. En particular, el blanco principal del nacionalismo catalán son los elementos que se ven como castellanos, y en especial, la lengua castellana" (Escribir 41). Sin embargo, incluso la sociolingüística catalana, reproductora de ese discurso nacionalista, define al grupo catalanohablante como "bilingüe". Esta contradicción no parece evitar la marginación, dentro de la idea de nación catalana configurada por estos sectores, de quienes optan por la lengua castellana como vehículo comunicativo y literario. 
La mirada nacionalista clásica sostiene que una nación preexiste a sus textos (y a sus representaciones artísticas en general), que transmiten y reflejan sus características específicas. Desde esta perspectiva, los textos capaces de dar cuenta de la nación catalana serían exclusivamente escritos en catalán. Sin embargo, desde esta posición se excluyen del corpus una gran cantidad de textos que consolidan y construyen esa nación: la primera gramática de Fabra, por ejemplo, fue escrita en castellano. Marsé, de hecho, registra esta mirada sesgada sobre la identidad lingüística de Cataluña y afirma: "[A]fortunadamente hoy en día la literatura en catalán está en pleno auge, yo diría que incluso ponen un poco demasiado el acento en esta literatura, y a nosotros, los que escribimos en castellano en Cataluña, que somos pocos, como Eduardo Mendoza o Enrique Vila-Matas, estamos no diría ninguneados, pero sí por detrás de las promociones oficiales" (Guisasola 281). Como indica King, la identidad hegemónica que hace equivaler nación y lengua "ha condicionado la identidad cultural de los catalanes que no se conforman con la representación renaixentista [...]. Esta identidad hegemónica ha tenido ramificaciones importantes para los escritores catalanes que emplean el castellano como lengua literaria" (Escribir 2).

Esta contradicción se disipa con el aporte teórico de Bhabha, quien, como hemos visto en el primer capítulo de esta tesis, afirma que la nación se construye en sus representaciones, y propone pensar la idea de nación como narración ("Narrando" 215). De este modo, el acto de la escritura es un acto fundante y estructurante de nacionalidad: todos los textos que se escriben en Cataluña, también escriben $a$ Cataluña, en un proceso de constitución nacional. La lengua vehicular de esos textos no es solamente el catalán, como afirma el discurso nacionalista, sino también el castellano, pues su población es mayoritariamente bilingüe. Por eso, consideramos que la nación catalana se estructura en y a través de las dos lenguas mayoritarias que se hablan en su territorio. 
En El monolingüismo del otro, Derrida critica la mirada nacionalista sobre la lengua unívoca y niega dos presupuestos corrientes que estructuran esta concepción: el primero, que la lengua es una propiedad natural, que asegura una identidad unívoca; el segundo, que la lengua es homogénea y común a sus hablantes. Encuentra en esta tendencia "a reducir las lenguas al Uno [...], la hegemonía de lo homogéneo" (24), ecos coloniales que quitan densidad al texto. Más adelante, afirma en una entrevista:

La lengua es eso mismo que no se deja poseer, pero que, por esta misma razón, provoca toda clase de movimientos de apropiación. Porque ella se deja desear y no apropiar, pone en movimiento toda clase de gestos de posesión, de apropiación. El desafío político de la cosa es que justamente el nacionalismo lingüístico es uno de esos gestos de apropiación, un gesto ingenuo de apropiación [...]. La dificultad política es: ¿cómo estar a favor de la más grande idiomaticidad - lo que hay que hacer, creo-defendiéndose en todo contra la ideología nacionalista? ¿Cómo defender la diferencia lingüística sin ceder al patriotismo, en todo caso a cierto tipo de patriotismo, y al nacionalismo? Tal es el desafío político de este tiempo. ("La lengua" s/p)

Afirma la necesidad de disociar entre idioma y propiedad, y asevera que el idioma no puede plantearse en términos de pertenencia, pues hay una relación de advenimiento con la lengua, de proximidad y de marca. Se posiciona a favor de la multiplicidad de lenguas, en tiempos de globalización en los que se ha sugerido la posibilidad de una sola, útil para el mercado. Sostiene que hay quienes creen que para combatir los nacionalismos hay que volcarse hacia una lengua universal y borrar las diferencias. Sin embargo, cree que no es esta la solución.

Derrida rehúye de las perspectivas nacionalistas y se opone a la multiplicidad de lenguas entendida en estos términos, pues apunta a disociarse, primero, de lo que denomina "la tentación nacionalista", pero también de "lo que liga la nación a un Estado, al poder de un Estado" ("La lengua" s/p). Agrega más adelante que precisamente porque el idioma no pertenece, se precipita hacia él la voracidad del nacionalismo, su furor apropiador. Como apunta Lorena Fioretti, la solución política "no es la transparencia de una lengua, sino todo lo 
contrario, la diseminación, la multiplicación infinita de las lenguas. No se trata de cultivar un idioma sino de producirlo; se trata de la traducción infinita a la que estamos destinados quienes habitamos el lenguaje" (87).

La mirada nacionalista considera a las lenguas como compartimentos estancos, reposa en el cultivo de una lengua, fija su estructura en gramáticas y diccionarios. Asume, además, una relación casi identitaria entre nación y lengua, y, por lo tanto, se apoya en la unicidad y en la compactación. Frente a esta perspectiva, sostenemos que existe otra, que asume a la lengua como móvil, contingente y abierta al cambio, plausible de ser habitada y modificada por sus hablantes. Como afirma Derrida, el sujeto nace a una lengua y la hereda, pues estaba allí antes que él. Sin embargo, afirma que esta herencia no debe ser pasiva:

Heredar es reafirmar transformando, cambiando, desplazando [...]. Es necesario firmar una herencia, contrafirmar una herencia, dejar su firma donde está la herencia, donde está la lengua que se recibe [...] se recibe y al mismo tiempo se da. Se recibe un don pero para recibirlo como heredero responsable, es necesario responder al don dando otra cosa, dejando una marca. (Derrida, "La lengua", $\mathrm{s} / \mathrm{p})$

Estas reflexiones pueden aplicarse incluso a quienes nacen, como los catalanohablantes, en un espacio bilingüe: más que salvaguardar la pureza de las dos lenguas, más que optar entre alguna de las dos, proponemos que es factible abrirse a la posibilidad de habitar ambas lenguas y de generar, como sociedad bilingüe, cambios específicos en los dos sistemas lingüísticos que den cuenta de su interpenetración. Consideramos que un hablante bilingüe habita las lenguas de un modo específico, múltiple y dinámico.

Es por esto que consideramos que el castellano de Marsé— como el de otros escritores catalanes de expresión castellana-cumple la doble función de enraizar en su espacio específico al tiempo que socavar la rigidez de sus fronteras. Como comprueba Robert Vann, incluso cuando los catalanes no hablan catalán, pueden comunicar su identidad nacional a 
través de ciertos recursos que tienen disponibles en el castellano (253). King también observa esto y apunta: "La no-coincidencia de lengua, cultura e identidad que se da en las obras de escritores catalanes de expresión castellana pone en cuestión las definiciones tradicionales de lo que es la "nación"” (Escribir 67). Plantea la posibilidad de que la manera particular de habitar el castellano de estos escritores los prefigura, en términos de Hutcheon, como "ex-céntricos", pues, según su criterio, son "marginados por la ideología dominante, en este caso, Castilla como representativa de España y de todo lo español”. Para King, los escritores como Marsé "se disputan la centralización de la cultura española al enfatizar lo local y lo periférico sobre lo universal y lo céntrico, escriben contra las metanarrativas españolas mediante el uso de narrativas que disputan y socavan simultáneamente estas metanarrativas" (Escribir 64). En este sentido, hacen visible que el contrario del eslogan franquista que proponía una España "una, grande y libre" no es una Cataluña idénticamente unificada y unívoca, y, en este proceso, se colocan en un lugar liminal, abierto a la hibridez: Marsé, por ejemplo, elige la figura del francotirador.

Es factible plantear que el opuesto lógico del nacionalismo no es otro nacionalismo, sino la idea de una nación múltiple, abierta y heterogénea, que asume una identidad dinámica, que habita y usa dos (o más) lenguas, y que se abre a su mutua transformación. En la misma línea, King registra que en las negociaciones que estos escritores tienen que llevar a cabo entre centro y periferia, socavan la base de la idea de identidad española homogénea. El crítico vislumbra la ironía de los efectos de la imposición lingüística franquista: al imponer el castellano como lengua unificadora del territorio español, abrieron también el camino para que los escritores catalanes de expresión castellana inviertan "y sigan invirtiendo ese proceso, llevando la lengua y la cultura de la periferia al centro y, al hacerlo, contestan al mito de la integridad española y lo subvierten en la lengua que es la base de este mismo mito, el castellano" (Escribir 67). También, al escribir en castellano, socavan los cimientos del 
nacionalismo catalán, que propone una identidad excluyente entre lengua catalana y nación. Al optar por la otra lengua, que el nacionalismo renaixentista coloca en posición antagónica con respecto a la catalana, pero aún así afincar sus novelas en los espacios geográficos, temáticas y contextos propios de la realidad de Cataluña, Marsé re-localiza el castellano y hace visible que el castellano también es la lengua nacional. Desde una posición de borde, hace explotar la equivalencia entre (una) lengua y nación. ${ }^{80}$

Esta doble "jugarreta" contra el nacionalismo español y contra el catalán puede encuadrarse dentro de lo que Michel de Certeau ha denominado "táctica". El filósofo francés propone esta categoría en relación con el uso de las prácticas impuestas por los sectores dominantes: el nacionalismo español, a nivel estatal, impone un castellano modélicorepresentado por instituciones como la Real Academia Española—que establece una variante normativa del uso de la lengua, central, frente a la que todas las otras formas de uso resultan variantes secundarias o laterales; al mismo tiempo, el gobierno autonómico catalán también asume la perspectiva nacionalista de imponer una equivalencia unívoca entre nación catalana y lengua catalana. Para este sector, la lengua catalana es la única capaz de dar cuenta del “espíritu nacional” de Cataluña, e invisibiliza el carácter bilingüe de la inmensa mayoría de su población. Ambos nacionalismos despliegan lo que de Certeau denomina "estrategias" para consolidar y mantener su espacio de poder. De Certeau define: "Llamo estrategia al cálculo (o a la manipulación) de las relaciones de fuerzas que se hace posible desde que un sujeto de poder (una empresa, un ejército, una ciudad, una institución científica) resulta aislable. La estrategia postula un lugar susceptible de ser circunscrito como algo propio" (42). Frente a las estrategias de los nacionalismos, Marsé despliega su “táctica”, concepto que implica una cierta desviación

\footnotetext{
${ }^{80}$ No deja de ser relevante apuntar, además, que la opción por el castellano tiene también efectos prácticos en lo que refiere a la difusión de su mensaje. De acuerdo a los datos del Instituto Nacional Cervantes, el castellano es hablado por aproximadamente 450 millones de personas en el mundo. Es, además, la cuarta lengua nativa más frecuente, y ocupa el segundo lugar en las comunicaciones internacionales. También es factible considerar una motivación financiera, pues el mercado en español es más vasto. (Datos disponibles en https://www.cervantes.es/imagenes/File/prensa/E1\%20espaol\%20una\%20lengua\%20viva.pdf).
} 
en el modo de hacer cuando no existen alternativas para rechazar aquello que se impone. La táctica involucra un "hacer funcionar en otro registro", "subvertir desde dentro". Es una forma de resistencia que "no tiene más lugar que el del otro. Además, debe actuar con el terreno que le impone y organiza la ley de una fuerza extraña" (Certeau 38). Ya dijo Derrida que la lengua no nos pertenece, $\mathrm{y}$, por lo tanto, es imposible modificarla a nivel individual, pues se sostiene en una serie de convenciones sociales, políticas e ideológicas. Al servirse de un castellano híbrido como lengua literaria, Marsé despliega su táctica que socava al mismo tiempo las ideas de que el "verdadero" castellano es el de Madrid, y que la literatura catalana debe escribirse en catalán. Derriba así dos prejuicios inversamente complementarios.

La lengua literaria de Marsé es un castellano localizado, arraigado en una situación geolingüística particular. Debido al contacto permanente que se da en esta región entre las lenguas catalana y castellana, ostentan características específicas, fruto de esta interrelación: el castellano de Cataluña está interferido por el catalán. ${ }^{81}$ Como registra Maurice van Overbeke, el término "interferencia" fue tomado de la física, en donde se refiere al encuentro entre dos movimientos ondulatorios, con el resultado de un reforzamiento o una anulación de la onda (77). Se hace así manifiesto que el término "interferencia" es neutral para la física, aunque, como observa Lluis Payrató, fuera de ese ámbito la palabra tiene connotaciones negativas (15). Esto ha llevado a algunos lingüistas a referirse a la interferencia lingüística en términos de error: Barry McLaughlin, por ejemplo, afirma que este fenómeno implica "esos errores que ocurren en el proceso de aprendizaje de una lengua segunda (B), que reflejan la adquisición de una lengua previa (A) y que no se encuentran en el desarrollo normal de quienes adquieren la lengua B como lengua primaria" (66-67).

\footnotetext{
${ }^{81}$ Aunque no nos detendremos en esto en este estudio, también hay que mencionar que el catalán de Cataluña se encuentra a su vez interferido por el castellano, y presenta características que lo distinguen frente, por ejemplo, al del Rosellón francés.
} 
Edward Sapir, por su parte, rehúye de las clasificaciones normativas sobre el funcionamiento del lenguaje y analiza las relaciones entre lenguas desde una perspectiva descriptiva. Advierte que las necesidades de intercambio a nivel social exigen situaciones de intercambio lingüístico, y que, en este marco, las lenguas entran en contacto. Sapir indica que es frecuente que existan préstamos de palabras entre lenguas y afirma: “[C]uando hay préstamo cultural, siempre existe la posibilidad de que las palabras asociadas sean tomadas prestadas también" (193). Marius Valkhoff, por otro lado, registra que existen dos tipos de préstamos léxicos, a los que denomina "préstamos de comodidad" y "préstamos de necesidad". Sostiene que los primeros se originan por razones de carácter afectivo, y no por inadecuación léxica de la lengua receptora, mientras que los segundos se vinculan con la inexistencia de un término equivalente a aquella palabra que se "toma prestada" (9).

Para Joan Veny, el "préstamo" llega a integrarse exitosamente debido a varios motivos de tipo lingüístico. El primero se vincula con la capacidad derivativa del ítem léxico: Veny revisa la palabra "burro" integrada en el catalán y observa que este término castellano ha generado varias palabras catalanas asociadas. El segundo de los motivos que registra se refiere a la proliferación semántica del término: "burro" significa, al mismo tiempo, "estúpido", “animal de carga", "tipo de carro", “calentador de cama” y “chichón”. El tercer motivo es, para Veny, la capacidad de adaptación fonética: "burro" ha dado lugar a "burru” en catalán oriental y a "burrt" en mallorquín. Finalmente, resalta la importancia de la productividad fraseológica de la palabra, en este caso, "burro" ha generado, entre otras, frases como "caure del burro" (darse cuenta de un error) o "carregat com un burro" (cargar mucho peso) (342).

Además del préstamo de palabras, otro fenómeno frecuente en el habla de muchos hablantes bilingües es lo que se denomina "code-switching”, o cambio de código. En este caso, los hablantes se deslizan de una lengua a otra en ciertos momentos de su discurso, aunque sin alterar ninguna de las dos. Debido a la percepción de que el "code-switching” puede plantearse 
como una extensión del "préstamo", muchos lingüistas proponen que éstos son las dos puntas de un continuum. ${ }^{82}$ Revisaremos este tipo de operaciones lingüísticas más adelante, fundamentalmente centradas en La oscura historia de la prima Montse.

Por otra parte, Weinreich, uno de los primeros lingüistas en estudiar este fenómeno en profundidad, advirtió que la interferencia no se trataba sencillamente de préstamos de palabras entre lenguas o de cambios de código, sino que describía un fenómeno sistemático más complejo, muy frecuente en el habla de comunidades bilingües. Weinreich observó ciertas anormalidades en el uso de la lengua de algunos bilingües, y definió el término "interferencia" como "las instancias de desviación de la norma de cualquier lengua que ocurren en el discurso de un hablante bilingüe como resultado de su familiaridad con más de una lengua, es decir, como resultado del contacto de lenguas" (1). Más adelante, Jean Dubois, en esta misma línea, precisó: "Se dice que hay interferencia cuando un sujeto bilingüe utiliza en una lengua-meta A un rasgo fonético, morfológico o sintáctico característico de la lengua B. [...] [L]a interferencia es individual e involuntaria, mientras que el préstamo y el calco están en vías de integración o están integrados en la lengua" (360). En un primer momento, entonces, el fenómeno de interferencia se estructuró alrededor del comportamiento particular de ciertos hablantes bilingües a nivel individual, en lo que se conoce hoy como "interferencia estricta” (Blas 269).

Sin embargo, otros lingüistas, como Suzanne Romaine, han señalado que la interferencia no puede ser vista como una desviación de una organización gramatical básica, sino que la gramática de algunas comunidades bilingües es construida a partir de la interferencia. Para Romaine, esto pone en jaque nociones como "gramaticalidad" y “aceptabilidad" (286). Esto contribuye a hacer visible que la lengua es un sistema social de convenciones, y que, si bien existen instituciones que determinan la "aceptabilidad" y la "gramaticalidad" de ciertas formas de uso, también es cierto que los verdaderos dueños de la

\footnotetext{
${ }^{82}$ Myers-Scotton, Treffers-Daller, Backus, Mahootian, Boyd, todos citados en Clyne.
} 
lengua son los hablantes: la agramaticalidad de ciertas estructuras no será percibida como tal por los miembros de una comunidad que las usan diariamente. Para explicar la diferencia entre interferencia estricta e interferencia en un sentido más laxo, Weinreich acude a la dicotomía saussuriana y plantea que existen, en realidad, dos tipos de interferencia. Las interferencias en el habla son aquellas que hemos definido como "estrictas", es decir, anormalidades lingüísticas en una lengua debido a la influencia de otra, a nivel individual, propias del comportamiento de algunos hablantes bilingües. Las interferencias en la lengua, por otro lado, son usos de la lengua divergentes de la norma, habituales en toda una comunidad lingüística. Esto implica la transformación de un sistema lingüístico debido al contacto con otro. Weinreich se sirve de una metáfora para discernir entre ambos tipos de interferencia y sostiene: "En el habla, la interferencia es como la arena en el cauce de un arroyo; en la lengua es como la arena depositada en el fondo de un lago" (11).

Haugen también observa la diferencia entre estos dos tipos de interferencia, y plantea que el término debe reservarse para los casos en los que dos normas lingüísticas se superponen en un mismo elemento debido a la dificultad individual de los diferentes hablantes bilingües en mantenerlos separados. Para Haugen, entonces, la interferencia es solamente estricta, y "cuando la desviación acaba siendo adoptada por la comunidad deja de ser interferencia" (“Problems" 10). William Mackey continúa esta línea de análisis y separa la "interferencia" de la "integración", al tiempo que define ambos términos: "Con interferencia, me refiero al uso de elementos de una lengua o dialecto al hablar o escribir otro, es característico del mensaje. Por integración, me refiero a la incorporación dentro de una lengua o dialecto de elementos de otro, es característico del código" (195). Mackey propone la idea de un continuum entre interferencia e integración, y sostiene que la integración es una cuestión de grado, pues será mayor cuanto más asimilado se encuentre un elemento a las normas del sistema lingüístico en el que se integra, y cuanto mayor sea su uso en el habla de la comunidad. De este modo, advierte 
el lingüista, los rasgos fonéticos, sintáctico-gramaticales, léxicos y semánticos integrados no deben considerarse ya como interferencias, "sino como una verdadera forma estándar, que sustituye a la anterior" (312).

Sinner resalta también la dificultad de determinar dónde acaba la interferencia y dónde empieza la integración. Sostiene que estos límites son muy difusos, "ya que los cambios en la lengua no ocurren a saltos sino sucesivamente" (60). En la misma línea que Mackey y Payrató, sitúa los fenómenos de interferencia e integración en una misma línea continua, pero distingue, a su vez, dos tipos de integración. Analiza la situación lingüística de Cataluña y los fenómenos de contacto entre el catalán y el castellano, y afirma:

Hay que distinguir entre la integración formal (que sería la que se suele llamar asimilación o adaptación), y la integración social, es decir la frecuencia de uso y/o la difusión de un elemento. La integración social llevaría a la consagración por el uso, es decir, integración en normas de uso, así como, posible pero no necesariamente, a lo que queremos llamar integración institucional, la integración en una norma prescriptiva, es decir, la admisión por una institución normativizadora, como la RAE en el caso del castellano. (89)

En este sentido, el castellano en el que se expresa Marsé presenta las especificidades propias de su interferencia con el catalán. Algunas de sus particularidades son consideradas erróneas por la normativa_ por la RAE — aunque son de uso extendido en el territorio catalán. Como observa Badia, “el origen catalán de una persona que habla castellano es remarcado tanto por rasgos fonéticos y gramaticales como por alguna palabra que no está en el diccionario" (Llengua 151).

En sus novelas hay, en primer término, algunos préstamos léxicos sin letra en bastardilla. En La oscura historia, por ejemplo, Marsé le hace decir a Simón: “-Es que también 
hago de paleta, a ratos. Oye, ¿tú piensas confesar?” (150). Según el Diccionari de la llengua catalana, ${ }^{83}$ "paleta" es el término catalán para designar a un albañil.

Otra marca de la lengua catalana en el castellano de Marsé se observa en el uso de ciertos términos que, si bien se encuentran en el diccionario de la RAE, se usan de otro modo en Cataluña. A veces, esa divergencia se vincula con la frecuencia de uso; un ejemplo de esto es el sustantivo "bamba" para designar a las zapatillas de lona. La sexta acepción del término en el diccionario de la RAE informa este significado. Sin embargo, la palabra no es frecuente en el habla de Madrid. La frecuencia de uso en Cataluña es notablemente mayor, como indica Sinner (308). Una compañera de pelota de Nuria, en La oscura historia, "se agacha para atarse los cordones de las bambas" (11) y la propia Nuria, algunas páginas más adelante, surge en el recuerdo de Paco utilizando el mismo calzado: "Sobre las soleadas baldosas que llevaban a los vestuarios, tus pies calzados con bambas y calcetines blancos se movían silenciosos y lentos, cruzándose cuidadosamente" (113).

Tampoco es frecuente el adjetivo "chafardera" en el habla de Madrid. Este término se encuentra en el diccionario de la RAE, el que indica su origen catalán ("del catalán xafarder") y su significado: "chismoso, cotilla". Si bien este término no es habitual en el resto de España, es frecuente en el castellano de Cataluña, y se encuentra presente en las novelas de Marsé.

El término es utilizado primero por Lola, una chica del Carmelo con la que Manolo tiene una cita. Lola dice: "Y no es que quiera meterme en lo tuyo, Manolo, en serio, yo no soy una chafardera, pregunta a quien quieras, pero también se habla de ti y de esa chica tan antipática, la Hortensia, la sobrina del Cardenal, siempre estás metido en su casa” (17). El adjetivo también es pronunciado por Teresa, quien responde la pregunta de Manolo:

-¿Esas que han venido hoy...? Si quieres que te diga la verdad, apenas las conozco. ¿Por qué me lo preguntas?

\footnotetext{
${ }^{83}$ Del Institut d'Estudis Catalans, disponible en https://dlc.iec.cat/.
} 
Por otra parte, el hecho de que el término "chafardera" sea utilizado tanto por Lola como por Teresa da cuenta del nivel de integración que tiene en el castellano de Cataluña. Manolo integra a Lola dentro del espacio de lo Otro, pues la considera una de "las niñas del Carmelo" (16). En contraposición, Teresa, como hemos visto, encarna enteramente el espacio de lo Propio. El uso del término para la autorreferencia en los dos espacios traza líneas entre ambos universos, y comprueba que, cuando una palabra de una lengua se encuentra totalmente integrada en un sistema lingüístico diverso, es utilizada tanto por hablantes bilingües como monolingües.

Otras veces, la divergencia en el uso de un término se asocia con un sentido figurado que adquiere una palabra en Cataluña, y que no se presenta en Madrid. De este modo, la palabra "bleda” significa, según la RAE, “acelga”. El Diccionari también ofrece esa definición como primera acepción, aunque presenta también una segunda posibilidad: “persona no espabilada, carente de vida o de temple". Es en este sentido — y no en el estrictamente castellano — que usa el término Marsé, cuando le hace decir a Manolo: "Y este señor me ha manchado y me ha quemado, y las mujeres a veces, perdona, pero las mujeres sois unas bledas" (103).

El término "torre" también se usa de modo discordante. Aunque la RAE registra—en su acepción séptima-que el sustantivo se utiliza en Cataluña, Murcia y Zaragoza para denominar "una casa de campo o de recreo, o granja con huerta", esto no es del todo preciso, pues también, según el Diccionari, puede designar—en catalán—a cualquier “casa unifamiliar de más de una planta, con o sin jardín". De hecho, "torre" puede designar cualquier tipo de casa, ubicada tanto en el campo o en la ciudad, y no necesariamente destinada a pasar una época del año como las vacaciones. Como apunta Sinner: “[T]orre"” se ha convertido en denominación de un determinado tipo de vivienda que en Madrid, por ejemplo, se llamaría simplemente "villa"' (382). 
El término "torre" es muy frecuente en la novelística de Marsé: Norma "se crio entre algodones en una fantástica torre del Guinardó rodeada por un inmenso parque” (El amante 7), al tiempo que Marés vivía "en lo alto de la calle Verdi, en una vieja y destartalada torre con jardín situada en una ladera contigua al parque Güell” (19). También los Claramunt residían en una torre, y Paco recuerda: “[C]on aullidos de pariente pobre todavía hoy evoco la habitación de mis primas en la torre, sus camas policromadas, cierto sentimiento de exclusión que habría de crecer y devorarme" (La oscura 55). Asimismo, el Cardenal vivía en "una torre de dos plantas, pequeña y ruinosa" (Últimas tardes 37), y Teresa vive con su familia en "la torre de los Serrat" (50). Esto comprueba que el sustantivo se utiliza de un modo más amplio que el normado por la Real Academia Española, en sintonía con el significado descripto en el diccionario catalán.

En algunos casos, la escritura de Marsé también presenta fragmentos directamente en catalán. Estas situaciones de code switching son frecuentes en los diálogos, lo que aporta verosimilitud a la construcción de ciertos personajes. El siguiente fragmento ilustra diversas operaciones de interferencia, entre ellas el cambio de código:

¡Ah, las dones de Barcelona tiren molt, noi, nos conocemos! Recomienda el profesor Guillot un simple acto de humildad ante el sagrario, y solo, sin testigos, simplemente dejarse caer de rodillas y decir: "Señor, ayúdame". Por supuesto, tú no eres, añade, como ese desgraciado, ese ignorante payés que anda siempre con su pintalabios y que de noche se empastifa (menudo susto se han llevado las monjitas al hacerle la cama, ¡creían que era sangre!) y se masturba a la luz de la linterna, dice que el carmín da una gran suavidad a las manos, el animal, por fin le habían descubierto, su compañero de cuarto, el oficinista, lo había comunicado al mosén para evitar el mal ejemplo; no, él no era como ese pobre anormal [...]. (La oscura 167)

La cita registra, en primer término, una situación de code-switching, que se resalta con letras en bastardilla. Para este tipo de situaciones lingüísticas, Pieter Muysken y Roeland van Hout describen tres puntos en la línea continua que se establece entre el préstamo y el code- 
switching. El primero, la inserción, implica "la inserción de material (artículos lexicales o componentes enteros) de una lengua a la estructura de otra lengua" (3), lo que da lugar a una estructura ABA. El ejemplo con el que Michael Clyne ilustra esta definición-“"Yo anduve in a state of shock por dos días" (73)—confirma su relación de identidad con el concepto de préstamo. El segundo tipo que registra Muysken es el de la alternación, que implica "la alternancia entre las estructuras de las lenguas" y suele darse cuando "las dos lenguas presentes en la cláusula quedan relativamente separadas" (3). Según Clyne, esto suele darse cuando las lenguas comparten el criterio para ordenar sus términos, y el ejemplo que ofrece es: “Ándale pues and do come again” (Clyne 74). El tercer punto del continuum, la lexicalización congruente, es un proceso donde "material de diferentes inventarios léxicos converge y comparte una estructura gramatical" (3). Esto se da entre lenguas que cuentan con estructuras similares, y los elementos léxicos de una de ellas pueden ser insertados en una construcción de la otra. El ejemplo que ofrecen Muysken y Roeland van Hout para este caso es: "Bueno, in other words, el flight que sale de Chicago around three o'clock" (302). Consideramos que el fragmento citado anteriormente se encuadra dentro de la categoría de "lexicalización congruente", dada la facilidad de alternancia que puede darse entre ambas lenguas y el hecho de que, en esta primera oración exclamativa, las lenguas se imbrican y no guardan distancia entre sí.

La inclusión de fragmentos en catalán es altamente frecuente en este sector de $L a$ oscura historia, "Los misterios de colores". Resulta una operación fundamental para sostener la verosimilitud de la trama que los personajes se expresen-aunque sea solamente en unas líneas - en catalán, pues se reúnen en un encuentro organizado en Vic-un pueblo pequeño, habitado mayoritariamente por catalanohablantes-por la rama catalana de la Asociación Cristiana de Jóvenes. 
La hibridación también se observa en el término "payés", no incluido en el diccionario de la RAE ni en el Diccionari. Éste último sí registra "pagès", en el sentido de "hombre de campo". Marsé ha castellanizado la ortografía del término catalán para lograr una equivalencia fonética. Tampoco el verbo "empastifar" es aceptado como válido por la RAE. Según el Diccionari, "empastifar" designa el acto de "ensuciar, especialmente con una sustancia pastosa o viscosa, con un tinte", lo que es compatible con la situación referida en el fragmento. Finalmente, el término "mosén” sí es aceptado por la RAE, aunque en su definición se indica su origen catalán-“del cat. mossén "mi señor"”. Aunque esta palabra no es de uso frecuente en el castellano central, sí ha sido aceptada por la normativa, por lo que está totalmente integrada en la lengua castellana.

La frecuencia de uso de un término sobre otro también implica un modo específico de habitar una lengua. Como registra Sinner, "la situación lingüística de Cataluña podría reflejarse en las prácticas discursivas, particularmente a nivel de la comunicación metalingüística. Un aspecto muy importante es la autodefinición con respecto de la lengua (orígenes lingüísticos), de la procedencia geográfica y de la identidad cultural" (469). En esto cobra especial relevancia la selección del término "castellano" por sobre "español” para referirse a la lengua oficial del Estado peninsular. Sinner observa "la posible preferencia de los hablantes bilingües españoles a usar 'castellano' en vez de 'español' para referirse a la lengua oficial del Estado” (469). De hecho, no existe ni una sola mención en ninguna de las novelas estudiadas al "español” como lengua, aunque sí abundan las referencias al "castellano". En La oscura historia, Salvador cambia de planes con respecto a la opción de lengua para su discurso: "Había preparado la conferencia para ser pronunciada en lengua vernácula, pero a última hora, considerando la composición étnica del auditorio, cuya asistencia sobrepasaba en mucho los cálculos previstos, decidió, de acuerdo con la junta, hablar en castellano" (42). También en El amante bilingüe, Marés llama a la Oficina de Assessorament Lingüístic para escuchar la voz de Norma, y le pide 
que le traduzca algunas palabras para contar con carteles en las dos lenguas en su tienda. Norma contesta: "Dígamelo en castellano y yo le traduzco" (13). También el diccionario que compra Marés es "catalán-castellano" (60). Además, cuando Norma y sus amigos se reúnen con Totón Fontán, que es castellanohablante, "hablaban casi todo el rato en castellano con esa pronunciación gangosa y enfática tan característica de las familias rancias del Eixample" (50). De este modo, Marsé logra textualizar también la interferencia del catalán en el plano fonético. También es divergente de la norma la utilización del verbo "explicar". Como indica Sinner:

En castellano, 'explicar' se emplea en diferentes sentidos, entre ellos el de 'declarar', 'manifestar', o 'dar a conocer lo que uno piensa', en el sentido de 'exponer una materia, doctrina o un texto difícil, con palabras claras para hacerlos más perceptibles'. En el castellano de Cataluña, 'explicar' tiene algunos usos no habituales en las variedades del castellano de regiones en las que no se habla catalán, lo que se ha explicado con los usos habituales del verbo 'explicar' en catalán donde se dice 'explicar una història' (cast. 'contar una historia'), 'un conte' (cast. 'cuento'), 'un acudit' (cast. 'chiste'), 'un esdeveniment' (cast. 'acontecimiento'), 'un succés', etc. Además de las formas verbales, también el sustantivo 'explicación' se encuentra en contextos donde en castellano se esperaría 'narración', por ejemplo. (424)

Es en el sentido de "narrar" que Marsé utiliza este verbo en La oscura historia, nuevamente en la sección "Los misterios de colores", cuando uno de los coordinadores del cursillo relata su conversión:

¡Barcelonadas y purgasions!, añade, y explica con sonrisa lupina cómo él fue tocado un día por la luz y en qué misteriosas circunstancias, pues había sido un mal esposo y un mal padre, un gandul, un borracho recalcitrante y un sifilític podrit de barcelonadas (luego explicaría, en un sereno paréntesis, el sentido que esta expresión tiene en la comarca: barcelonadas son las escapadas a la capital para ir de burilla). Empieza la autoconfesión, la minuciosa exposición de horrores por los que pasó antes de ser tocado por la luz. (162) 
En este fragmento, se presenta también el sustantivo "barcelonadas", seguido de su definición, pues no ha sido todavía aceptado por la norma-ni la RAE ni el Diccionari lo consideran, aunque sí se usa en el habla de Cataluña. Este término funciona como un excelente ejemplo de consciencia metalingüística de Marsé. Además, se observa también la operación de préstamo de algunas palabras, lo que aporta mayor verosimilitud al discurso. Estos préstamos se integran, entonces, en lo que Valkhoff ha denominado “préstamos de comodidad", pues existen términos equivalentes en castellano para cada una de las palabras escritas en catalán.

Uno de los ejemplos más cabales del uso del verbo "explicar" en el sentido referido por Sinner se encuentra en El amante bilingüe. Marés/Faneca desarrolla un vínculo con Carmen, la muchacha ciega que vive en la pensión Ynes narrándole las películas que pasan por la televisión:

Aquel mundo atrafagado y artificioso lleno de voces y melodías sugestivas, aquella otra vida en colores de la que ella sólo podía captar su rumor, [...] le llegaba a través de la voz impostada y persuasiva de Faneca, que se lucía especialmente con las películas: a Carmen era lo que más le gustaba que le explicaran, y, según ella, el señor Faneca sabía contárselas maravillosamente; le hacía ver la película, porque no se limitaba a explicar las imágenes, no sólo describía para ella los decorados y los personajes, narrando lo que hacían en todo momento y cómo vestían, también comentaba sus emociones y sus pensamientos más ocultos. Según el señor Tomás y el señor Alfredo, [...] las películas ganaban tanto explicadas por el señor Faneca, que era mejor oírlas que verlas [...]. En cualquier caso, era tanta la afición de la muchacha a estas películas explicadas, que alguna vez Faneca intentó zafarse [...] [pero si] veía a Carmen sentada frente al televisor [...] acababa por sentarse junto a ella y explicarle las imágenes. De noche, hallándose en el bar de enfrente [...] veía entrar al señor Tomás [...]: que la niña había preguntado por él, que si no pensaba ir a ver la película, que quién se la iba a contar [...]. (98)

Es evidente que el uso de "explicar" en esta cita excede el significado castellano del verbo. La idea de narración se enfatiza a través de la construcción de un profuso campo semántico que comprende términos como "contárselas", "decorados", "personajes", "narrando", "cómo vestían", “contar". La idea, además, de "películas explicadas" o de "explicar las imágenes” no 
tiene demasiado sentido en el sentido castellano del término; sin embargo, si se lo considera como un sinónimo de "relatar", se abre una posibilidad más precisa de interpretación.

Otro verbo que Marsé usa de modo divergente es “vigilar”. El verbo en catalán es un equivalente parcial del castellano, pues puede utilizarse también para expresar un significado que no existe en castellano, asociado al verbo "cuidar". Es por esto que es frecuente la utilización de este verbo en lugar de "cuidar" o "velar". Marsé utiliza este verbo en este sentido en las tres novelas estudiadas. En El amante, Marés mira a su amigo Serafín, disfrazado en la noche del carnaval, y “[s]entía un extraño deseo de ir tras él y preservarle de algún mal, quería vigilar sus andares, asistirle" (43). Montse también siente la necesidad de proteger a Manuel en la playa: "Ella se echa de bruces a su lado, vigilante, mirándole como si velara su sueño" (La oscura 219). En Últimas tardes, Maruja le pide al primo de Teresa, José Miguel: “-Ven, José Miguel-. Cuando le tuvo delante le quitó los mocos con un pañuelo, le ajustó el slip sobre la barriguita y lo despidió con un cariñoso azote en el trasero. -Vigila a tu hermanita, que no se acerque demasiado a la orilla" (81). Con respecto a esta última cita, es consistente con el registro de Sinner, quien afirma que "especialmente el imperativo parece usarse con cierta frecuencia" (459).

La influencia de la lengua catalana en el castellano de Marsé también se observa en la recurrencia de la expresión "llevar prisa", no aceptada por la RAE. En esta locución, se observa la interferencia del catalán "portar pressa", lo que probablemente opera como modelo de la locución "llevar prisa", muy frecuente en el castellano de Cataluña. Así, cuando Hortensia y Manolo se encuentran por casualidad, "[1]a muchacha parecía llevar tanta prisa como él y la fuerza del choque la desplazó contra la pared" (Últimas tardes 139). También Nuria hace referencia a su apuro en estos términos, cuando le describe a Paco su encuentro casual con Manolo en el Ensanche: "Iba muy pensativo, solo, con la chaqueta al hombro. He estado a 
punto de atropellarle al subir a la acera para meterme en el garaje, me faltaba gasolina y llevaba mucha prisa, no quería regalarse el partido a esta presumida de Menchu" (La oscura 113).

Otra discrepancia de la norma en la construcción de una locución verbal por interferencia de la lengua catalana se observa en "hacer vacaciones". Como afirma Sinner, "el verbo catalán 'fer' es relativamente vacío desde el punto de vista semántico, lo que permite emplearlo en una serie de contextos en que las demás lenguas iberorrománicas emplean verbos más especializados" (523). El verbo "fer" suele configurar estructuras transitivas mucho más frecuentemente que el verbo "hacer" en castellano, lengua en la que se utilizan verbos más específicos como "dar", "tener", "llegar”, “tomar", “cometer” u otros. Sinner registra "hacer vacaciones" como uno de los giros del castellano en Cataluña más frecuentes. Esta frecuencia también se comprueba en la escritura de Marsé: “¿Que por qué ha venido a Colores? Un amigo que se lo venía aconsejando desde hace tiempo, qué tabarra, no le dejaba en paz. 'Y como ahora hago vacaciones, y además no tengo familia, vivo solo..."” (La oscura 138).

Tanto "llevar prisa" como "hacer vacaciones" pueden encuadrarse dentro de lo que la lingüística denomina “calco". Para este caso específico de interferencia entre el catalán y el castellano, resulta esclarecedor el estudio de Carmen Hernández quien afirma: "Dentro de la interferencia sintáctica se producen los calcos. Los calcos sintácticos son estructuras que se traducen tal cual del catalán y que se realizan con elementos propios del español, dando como resultado secuencias que no son normativas ni usuales en esta lengua” (68).

Ciertas construcciones exigen en catalán un tiempo verbal diverso del castellano. Por ejemplo, para expresar dos puntos en el pasado, uno anterior al otro, el castellano optaría por el pretérito pluscuamperfecto primero, y luego el perfecto simple, ambos del modo indicativo. Si lo que se refiere como pasado anterior, sin embargo, se presentara en voz pasiva, el hablante debería decidir si se encuentra ante una cláusula que indica acción—aunque no agencia—, lo que lo llevaría a optar por la pasiva clásica (ser + participio). La otra posibilidad es la pasiva 
de situación, indicada por la perífrasis estar + participio. De optar por la pasiva de situación, el tiempo verbal indicado para "estar" es el imperfecto. Este tipo de estructuras en castellano, entonces, requieren una construcción pasiva de situación en pretérito imperfecto en una cláusula y un verbo activo en pretérito perfecto simple en la otra: "cuando llegué, esto estaba hecho". El pretérito perfecto simple y el imperfecto, en este caso, se encuentran en el mismo plano temporal, y la idea de anterioridad se da por el uso de la pasiva de situación. En catalán, sin embargo, la temporalidad de los verbos no puede ubicarse en el mismo punto para este tipo de construcciones, por lo que se prefiere el uso del pretérito perfecto compuesto-más cercano al presente-para indicar el pasado más reciente. Estructuras como "La valla estaba rota cuando nosotros hemos llegado, de modo que no chille tanto" (Últimas tardes 20) son usuales en la lengua literaria de Marsé.

Otra de las discordancias con respecto a la norma de uso más frecuentes en el castellano de Cataluña es la neutralización de las irregularidades de ciertos verbos que son irregulares en castellano, pero regulares en catalán. Como indica Sinner, esto "se considera una de las mayores dificultades que han de vencer los catalanes al expresarse en castellano [...] suelen darse sobre todo ejemplos de neutralización de verbos en hablantes de las zonas de habla catalana" (222). Debido a que el manejo de las regularidades e irregularidades en el sistema verbal es uno de los puntos de la gramática más vigilados por las instituciones normalizadoras y por la comunidad de hablantes, la neutralización de la irregularidad de un verbo como "andar" suele ser percibida como error y castigada. Hemos visto que Marsé es muy cuidadoso de su uso del lenguaje - un cartel en su estudio advierte que "el esmero en el trabajo es la única convicción moral del escritor"- por lo que es probable que haya duplicado sus esfuerzos por no cometer un "error" de este tipo. Sin embargo, la gramática del catalán se ha filtrado en Últimas tardes, en donde escribe, sobre Luis Trías: “[T]enía ese aire un poco perplejo de manso seminarista en vacaciones, con un leve balanceo de la cabeza a causa del vértigo teológico, del 
peso trascendental de las ideas o de una simple flojera del cuello, como si andara graciosamente desnucado" (65).

Otra de las fuentes de interferencia entre el catalán y el castellano se asocia con los usos de "ir" y "venir". En castellano, "venir" implica un movimiento hacia el lugar en el que se encuentra el hablante, mientras que "ir" no se emplea nunca para referir un movimiento hacia quien habla, sino que involucra un movimiento desde su posición hacia otra. En catalán, "venir" se usa asimismo para desplazamientos hacia el lugar donde se encuentra quien recibe el mensaje o donde se encuentra quien envía del mensaje, y "anar" se utiliza para hacer mención a un movimiento no dirigido en dirección del receptor o del emisor. Esto también es patente en las novelas estudiadas; Salvador le dice a Paco, en La oscura historia: "No me vengas con excusas, Paquito, sé que no tendrás resueltos tus asuntos hasta el lunes. Decidido: pasarás el fin de semana con nosotros. Dentro de media hora vengo a recogerte al hotel" (26). Al ser Salvador el que abandona su espacio de referencia para dirigirse al de Paco, la opción estándar es el verbo "ir" en castellano, por lo que en la elección de "venir" se observa la influencia del catalán. También Manolo deja el Carmelo para ir a ver a Teresa, sobre el final de Últimas tardes, aunque no "va" a ver a Teresa, sino que "viene": "Aunque en la ciudad, desde hacía cuatro días, había perdido la noción de las horas, del día y de la noche, aquí pudo calcular [...] que debían ser más de las tres. Puesto que había venido, y no tenía nada mejor que hacer, esperaría a que amaneciera" (196).

Algo similar ocurre con los verbos castellanos "llevar"-que implica un movimiento de alejamiento del lugar en el que se encuentra el hablante-y "traer"-que da cuenta de un desplazamiento hacia el espacio de quien habla. La lengua catalana sólo cuenta con un verbo, "portar", para referir movimientos en ambas direcciones, lo que genera muchas veces usos divergentes de "traer" y "llevar" cuando los hablantes bilingües usan el castellano. Montse se desplaza desde la torre de los Claramunt hacia la pensión de Manolo, pero no le "lleva" un 
objeto sino que lo "trae": "En cuanto a los movimientos de Montse en torno a él, solo puedo decir esto: le visita con frecuencia pero no cada día, y sus visitas, en contra del parecer de la familia, se reducen al deseo de traerle La Vanguardia por la mañana para leer juntos las demandas de trabajo" (La oscura 203).

Esta cita también pone de manifiesto otra de las interferencias típicas del catalán en el castellano de Cataluña. Según la primera acepción de la RAE, el cuantificador "cada" en castellano se especifica léxicamente como distributivo, pues "indica que el sustantivo al que modifica denota un conjunto cuyos miembros se consideran individualmente y entran en una relación distributiva con algún otro elemento, usado ante sustantivos contables". ${ }^{84}$ Según el Diccionario de dudas y dificultades de la lengua española, "el uso de 'cada' con idea pura de generalización, olvidando el sentido fundamental distributivo, es catalanismo" (80). Es frecuente en Cataluña la sustitución de estructuras como "todos los días" o "todos los veranos" (que se refieren a la repetición de entidades idénticas) por otras de tipo "cada día" o "cada verano", que, de acuerdo con lo revisado en la RAE, tienen sentido distributivo. El uso generalizador de "cada" es muy frecuente en la escritura marseana. Hemos visto el ejemplo anterior en La oscura historia ("cada día"), también abundan en Últimas tardes ("Los tonos grises, malva y ocre estaban ya visiblemente resignados a madurar en el Paseo de la Bonanova, como cada año, y era casi seguro que el sol no conseguiría abrirse paso entre las nubes” (190)) y en El amante bilingüe (“Cuxot hizo descorchar una polvorienta botella de Rioja y Marés comentó una vez más su sueño de cada noche con el murciano dicharachero de largas patillas y ojos verdes, su otro yo" (28)).

Por otra parte, locuciones como "la mitad de", "la mayoría de", "la mayor parte de", "la totalidad de", "el ... por ciento de" también evidencian, en el castellano de Cataluña, interferencias del catalán. En castellano, estas construcciones requieren de un artículo a

\footnotetext{
${ }^{84}$ Fuente: http://www.rae.es
} 
continuación de la preposición "de" ("la totalidad de las personas"), pero en catalán este artículo no es necesario ("la majoria de + sustantivo"). Debido a la influencia de esta lengua, la omisión del artículo es muy frecuente en el castellano específico del territorio catalán. Marsé construye estructuras de este tipo, como la siguiente, de La oscura historia: "Luego, querida prima, siguiendo en mañanas semejantes por ese largo y difícil camino [...] quizá a mitad de trayecto nació la congoja, la primera lágrima de lucidez" (128).

Tampoco el uso de los cuantificadores indefinidos en castellano se corresponde con el indicado por la norma. En castellano, "ninguno" y "alguno" son cuantificadores indefinidos no universales, y tienen, como "uno"- del que derivan-, flexiones de género y número de acuerdo al sustantivo que acompañan. Aunque "ninguno" y "alguno" registran a nivel léxico una relación de antonimia, también son intercambiables en estructuras como "no lo he visto en parte alguna" y "no lo he visto en ninguna parte", es decir, la equivalencia de significado se logra en las estructuras — negadas — del tipo "sustantivo + alguna (o variantes)" y "ninguna (o variantes) + sustantivo”. En catalán, sin embargo, estos cuantificadores construyen sentido de un modo diverso, y, como registra Sinner, "en el castellano de las zonas catalanohablantes se ha documentado el empleo de los cuantificadores indefinidos siguiendo el modelo catalán" (244). Ejemplos de esto abundan en las novelas estudiadas, como: "No tardó, sin embargo, en descubrir que todo esto eran balbuceos sin utilidad ninguna de orden inmediato y que había que esperar" (Últimas tardes 40) o "los sentimientos y los deseos eran constantemente revisados [...] según un concepto de la vida que, desgraciadamente [...] no guardaba relación ninguna con la realidad de su clase" (Últimas tardes 65).

En el plano adverbial, también se observan interferencias del catalán en cuanto a la opción de uso. La RAE reconoce el adverbio "malamente" como posible, sin embargo, el castellano de Madrid suele optar por el término "mal" en su lugar. Sin embargo, en catalán, "mal" es un adjetivo (equivalente a "malo" o "mala"), y la única alternativa posible para el 
adverbio es la que contiene el sufijo "mente". Es por esto que en el castellano de Cataluña, “malamente" es la opción más frecuente, y esto también es perceptible en la escritura marseana. Los ejemplos de este uso son profusos, seleccionamos dos para ilustrar esta opción de vocabulario. Cuando Paco habla con Manuel sobre la delicada situación de Montse dentro de su familia, éste responde: "Pero yo se lo noto apenas la veo entrar por esa puerta; hay días que tal parece que ya la hayan echado de su casa. Esto puede acabar malamente" (La oscura 200). También se registra el uso de "malamente" en Últimas tardes: "Resultaba curiosa esta sensación de seguridad que experimentaba aquí, en medio de este orden y silencio confortables, en relación con la torpeza [...] [de] su ambiente natural, en su casa [...] o con el Cardenal y su sobrina (recordó la última visita que les hizo, y lo malamente que había sacado dinero)” (123).

El uso de los pronombres y adjetivos demostrativos también muestra las marcas del contacto entre lenguas. En el castellano de Cataluña se registra un mayor uso de "este", "esto" y “esta”, en detrimento de "ese", “eso" y "esa". Esta mayor frecuencia se vincula con el hecho de que "el catalán mantuvo el sistema binario heredado de la deconstrucción del sistema demostrativo latino, [mientras que] el español regeneró de nuevo el grado intermedio" (Martín Miñana 331). En otras palabras, el catalán utiliza el demostrativo "aquest" y sus variantes flexivas para un primer y segundo grado de cercanía con respecto al emisor del mensajesituaciones en las que el castellano opta entre "este" y "ese" y sus variantes-, y reserva “aquell” y sus variantes de género y número para aludir a una cierta lejanía con respecto al emisor-al igual que el "aquel” castellano. Pau Martín Miñana resalta la diferencia que se observa en la partición del espacio específica del catalán, que se separa de otras lenguas latinas, como el francés, el italiano y el rumano: "En estos últimos, el primer grado señala solamente la cercanía, mientras que el segundo grado marca la media distancia y la lejanía. En cambio, el catalán presenta un primer grado que aúna la cercanía y la media distancia y un segundo grado que alude a la lejanía" (331). Esto lleva a los hablantes de castellano en Cataluña a confundir 
los usos de "este" y "eso" y sus variantes flexivas. Son profusos los ejemplos de un uso divergente de "este" en la escritura de Marsé. En El amante bilingüe, por ejemplo, Marés le habla al lustrabotas con el que lo ha engañado Norma, mientras él limpia sus zapatos:

Sigue lustrando el zapato por hacer algo, con gestos mecánicos. Pero emplea en su absurdo cometido una atención desmedida. [...].

-¿No puede dejar de frotar este zapato?

-Lo mío es sacarle lustre al calzado, ¿zabusté? Pero será mejor que me vaya, con su permizo. (6).

Dado que el lustrabotas está limpiando el zapato y que Marés se encuentra a una cierta distancia, el adjetivo demostrativo más apropiado es "ese", y no "este". También se observa un uso similar en La oscura historia: "Cuando la recogí me dijo que la llevara a la calle Entenza volando, que iba muy retrasada [...]. Llevaba un vestido demasiado caluroso para este tiempo, iba un poco endomingada" (111). Si consideramos que Nuria está recordando una situación ocurrida hace muchos años—-se encuentra con Paco, ambos adultos, hablando de Montse-, el adjetivo demostrativo indicado por la norma es "ese" tiempo, y no "este", debido a la distancia existente entre el momento del acto de habla y el "tiempo" al que se hace referencia. También en Últimas tardes: “Tenía aspecto de haber dormido mal [...]. Él comprendió en el acto que algo nuevo bullía también en esta cabecita rubia" (140). Manolo se refiere a la cabeza de Teresa utilizando el demostrativo "esta", tampoco apropiado debido a la distancia física.

Finalmente, es relevante también detectar otra particularidad del castellano de Cataluña que se plasma en la escritura de Marsé. Sinner registra: "La construcción interrogativa directa, de respuesta sí/no, en catalán, suele iniciarse por ‘que’: ‘Que tens gana?’ (‘¿Tienes hambre?’); 'Que ja has menjat?’ (‘¿Ya has comido?’). También en el castellano de las zonas catalanohablantes se puede encontrar esta construcción con 'que' átono no usada en el 
castellano de otras regiones" (268). Ejemplos de esto abundan en las novelas, como por ejemplo:

-¡A ver! ¿Fuiste tú o el Cardenal?

-Fue éste, mujer -dijo su hermana-. ¿Que no le ves la cara? (Últimas tardes 125)

Estas particularidades fortalecen a la hipótesis de que la escritura de Marsé se estructura en un castellano híbrido, abundante en interferencias de tipo léxicas, sintácticas, semánticas y de frecuencia de uso producto de la situación de contacto con el catalán. Joan Gilabert, de hecho, afirma que "la obra de Marsé tiene bien poco en común con otros novelistas no catalanes de su generación pese a escribir en castellano" (67). Agrega que la lengua literaria del novelista es "un castellano tan peculiar que sin el conocimiento de la lengua catalana puede mal interpretarse” (70). King añade: “[E]studios sociolingüísticos recientes y no tan recientes sobre el castellano empleado en Cataluña tienden a corroborar que el uso del castellano 'periférico' puede funcionar como seña de identidad catalana" (Escribir 63).

Por último, quisiéramos referir que la lengua no es solamente vehículo de la obra literaria sino, a veces, objeto de una reflexión metalingüística que se da, con un nivel creciente de intensidad, en las tres novelas relevadas. En primer lugar, en Últimas tardes, existen algunas referencias a la lengua, pero son escasas. Ya nos hemos detenido en el análisis de dos momentos relevantes en torno a esta temática: la exclusión de Manolo del universo de lo Propio por su incapacidad de hablar la lengua (su acento como marcador de origen, su incomprensión del catalán) (10), opuesto a los "graciosos morritos" (147) que, en el caso del acento catalán de Teresa, la textualizaban positivamente.

La oscura historia, por otra parte, condensa una pluralidad de situaciones en las que se presentan las dos lenguas, lo que aporta verosimilitud al relato. Las generaciones mayores de 
los Claramunt - no tanto Nuria y Montse, lo que sugiere nuevamente una tendencia a la apertura — suelen expresarse en catalán. Cuando Paco conoce a sus tías, ellas se dirigen a él— y hablan sobre él—en catalán: ““Criatura innocent...' 'Macu, sembla un Nen Jesús de Praga.' 'I la Conxi, na fent, la boixa...' 'Ves ell qué sap, pobret..."' (54). También Luis Claramunt se dirige a Paco en catalán: “Francesc! Les nenes no es toquen” (55). Estas líneas, marcadas en bastardilla por Marsé, comprueban la integración cabal de este espacio en el ámbito catalán.

La relación con la lengua también opera para ubicar a Paco en un espacio liminal, mestizo. Lee considera que "[1]a actitud de Paco con respecto a la lengua catalana se articula con su actitud hacia su (media) catalanidad; para decirlo francamente, si rechaza la lengua, rechaza la parte catalana de sí mismo" (“La oscura” 361). El siguiente pasaje, que ya revisamos con otros propósitos, muestra la relación de Paco con la lengua catalana:

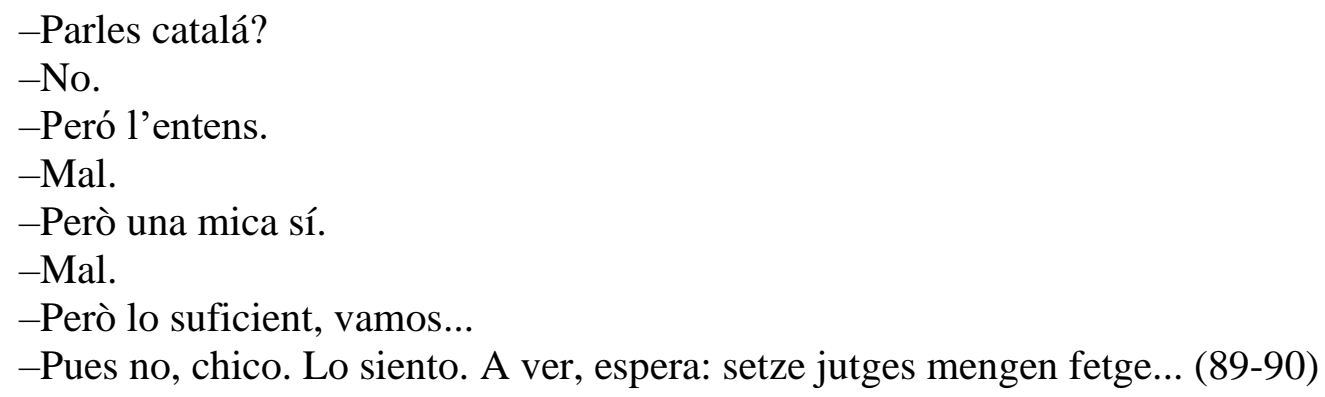

No creemos que la relación que Paco tiene con el catalán sea de rechazo pues esto lo ubicaría completamente en el espacio de la Otredad. Quizá sí puede haber una cierta hostilidad, aunque creemos que se dirige más a Salvador que a su lengua. A pesar de que Paco no habla la lengua, sí la entiende, pues puede sostener una conversación, y responder en castellano con coherencia. Además, desafía a su interlocutor pronunciando un trabalenguas en catalán, lo que confirma su competencia lingüística. Creemos que el vínculo que establece Paco con la lengua confirma su hibridez, su posicionamiento de cruce entre los espacios catalán y migrante. 
La oscura historia presenta, asimismo, operaciones de code-switching con otra lengua, la francesa. Cuando se reencuentran, Paco le dice a Nuria: "En este sentido, veo que el país no ha cambiado nada, sigue siendo una pura insensatez. Bon, laissons tomber. Comment ça va ta vie sexuelle?" (29). Según la clasificación de Muysken a la que nos hemos referido, este caso de code-switching puede plantearse como uno de alternancia, pues las dos lenguas presentes permanecen relativamente separadas. Por otra parte, la opción por la lengua francesavinculada con el hecho de que Paco reside allí-también comprueba que ésta tiene puntos de contacto con las otras dos: es, como el castellano, una lengua oficial estatal, aunque a nivel léxico-sintáctico, comparte muchas características con el catalán.

Ya desde su título, El amante bilingüe coloca el tema de la lengua en un espacio central. La novela pone de manifiesto la contradicción entre la diversidad cultural de Barcelona y el establecimiento de un proyecto político monolingüe. La esquizofrenia de Marés lo duplica en Faneca, y este trastorno también puede extenderse a la propia ciudad de Barcelona, que se debate entre el purismo catalán y la heterogeneidad cultural. Por un lado, Norma representa el espacio de lo Propio: no solamente habla catalán, sino que también, como sociolingüista, vigila la "pureza" de la lengua. Su nombre, de hecho, la emparenta con la idea de norma lingüística, al tiempo que la asocia con una caricatura creada por el Plan de Normalización para fomentar el uso del catalán, "La Norma". Es, además, amante de otro "centinela lingüístico" (El amante 16), Jordi Valls Verdú, un sociolingüista normalizador de mayor jerarquía que ella en el sistema. Tanto Norma como Valls Verdú hablan en catalán, y esta vez, la presencia de la lengua no es marcada en bastardilla por Marsé. Cuando conoce a Faneca, Valls Verdú dice "Molt de gust" (105), mientras que Norma traduce cada palabra que Marés le pide por teléfono, como por ejemplo, "abrics” (13). Estas dos figuras se alinean, a nivel lingüístico, con el proyecto monolingüe, propio del nacionalismo catalán. 
Por otra parte, la novela también pone en escena el tema de las lenguas en contacto referido en la primera parte de este apartado. Desde una perspectiva paródica—pues, como hemos visto en el capítulo cuarto, Norma se siente atraída por los sureños-, un amigo de Norma le explica a otro en qué consiste el trabajo de la sociolingüista:

-Norma se ocupa de las encuestas públicas y experimenta con... la lengua. Estudia los contactos conflictivos de las dos lenguas, el catalán y el castellano, tanto en lo individual como en lo social. Ese punto en que las dos lenguas se friccionan.

-O sea -intervino Ribas-, las dos lenguas en contacto vivo y caliente con el individuo.

-Idiota eres -dijo riendo Norma

-Puedes reírte lo que quieras -dijo Totón Fontán-. Pero yo empiezo a estar hasta el gorro del normativismo badulaque en el que ha caído el idioma catalán.

-Pues ya puedes ir preparándote, pobre castellanufo -dijo Ribas-. Verás auténticos prodigios. (55)

Esta cita pone de manifiesto la situación de tensión entre dos ideas homogeneizadoras y monolingües: la del nacionalismo catalán normativista frente a la de la imposición del castellano: Fontán es castellanohablante, y es, entre catalanes, acusado de ello. En la novela pueden observarse las dos caras de Barcelona. El nacionalismo catalán se observa en diversos puntos (las constantes llamadas de Marés al Plan de Normalización Lingüística, la bomba molotov que desfiguró el rostro del protagonista, las reflexiones de algunos personajes). Por otra parte, la población migrante en los barrios periféricos de la ciudad, pone en evidencia su carácter subordinado y lateral al catalán en este momento histórico. En esta novela, Marsé textualiza por primera vez la diferencia de lengua, y reproduce el acento andaluz, quizá caricaturizándolo: "Perdone, e uzté mu amable. Le estoy haciendo perdé mucho tiempo [...]" (13). El tema de la identidad, y de su fragmentación o estallido, entonces, no solamente atraviesa al protagonista sino también a la ciudad en la que vive. De esta manera, se observa la relación entre el conflicto individual y una interpretación de índole colectiva. 
En conclusión, el tema de la lengua — ya sea como instrumento vehiculizador de la obra literaria, o como centro de una reflexión metalinguiística que se plasma en la ficción-cobra especial relevancia en la escritura de Marsé. A nivel temático, la cuestión lingüística siempre está presente: al principio, se hace manifiesto su carácter como dispositivo de exclusión, luego se plantea la posibilidad de la hibridez y finalmente los conflictos lingüísticos se plantean en clave paródica, subvirtiendo su poder excluyente. A nivel lingüístico, la estrategia de Marsé consiste en utilizar una lengua que resiste las clasificaciones nacionalistas, y se separa al mismo tiempo del purismo catalán y del castellano. Interfiere el castellano con el catalán, y en esta interpenetración, hace visibles los vínculos y relaciones indisolubles que existen entre las lenguas, y la artificialidad que atraviesa cualquier intento de separación en términos dicotómicos. A través de su uso de este castellano particular, desplaza la lengua del centro a la periferia, y, además, se sirve de su popularidad de uso para multiplicar la difusión de su mensaje. Como una máquina encendida, activa, Marsé pone en contacto dos lenguas para construir una imagen de nación en conexión y abierta. En su obra, la lengua es soporte y recurso para resquebrajar las fronteras fijas: la lengua y su ejercicio recuperan su dimensión comunicativa, en el sentido esencial de la palabra. La estrategia lingüística de Marsé apunta a la comunicación, al contacto y a la inclusión en un discurso nacional amplio y convocante. 


\title{
Capítulo 6
}

\begin{abstract}
Algunas conclusiones
Este estudio ha demostrado que, a lo largo de las tres novelas estudiadas, el escritor catalán Juan Marsé pone en cuestión el carácter hermético del concepto clásico de nación para el caso catalán y propone una nueva forma de definir este constructo más vinculada con las ideas de la posmodernidad. Su novelística es permeable a una lectura que detecta una progresiva fragmentación de las fronteras que oponen lo autóctono a lo foráneo, articulada con el binarismo que rige gran parte del pensamiento moderno. En este sentido, problematiza también la cuestión de la identidad nacional y se pregunta qué y quiénes pueden integrarse en el espacio de lo Propio catalán, y qué tan fuertes son los bordes que delimitan este sector y lo separan de lo Otro migrante. De este modo, Marsé hace evidente el carácter de constructo de la idea monolítica de nación acuñada en la modernidad, y visibiliza la tensión entre la configuración identitaria a nivel comunitario de la sociedad tradicional y la posmoderna.

Este conflicto se presenta a través de la estructuración de diversos personajes y espacios que van asumiendo progresivamente significados asociados al cruce y a la hibridez. Es así como frente a la supuesta homogeneidad que implica la idea de nación catalana en términos clásicos, Marsé hace visible la diversidad y el mestizaje. Lleva esto a cabo a partir de la construcción de significados textuales opuestos que se asocian a uno y al otro ámbito (lo claro y lo oscuro, la delicadeza y la arrogancia, el saber institucionalizado y el empírico, la represión y la libertad sexual, entre otros). Gradualmente, ciertos espacios y personajes van adquiriendo de modo simultáneo características asociadas a lo migrante y a lo catalán. De este modo, invita a cuestionar la infranqueabilidad de los bordes que delimitan el espacio de lo Propio, y abre el
\end{abstract}


campo para poder reformular esta idea desde una perspectiva abierta a la articulación de diversidades.

Hemos visto que nuestra lectura puede desarrollarse en tres pasos sucesivos, relativos a las tres novelas estudiadas, y también a través de una operatoria a la que nos hemos referido como estrategia lingüística, transversal a toda la obra de Marsé. El primer paso de esta construcción se vislumbra en Últimas tardes con Teresa, de 1966. En esta novela, el autor hace foco en el arribo al escenario local de un Otro migrante, diverso, y da cuenta de una cierta antigüedad en este fenómeno migratorio, al situar la peripecia de la novela diez años antes de su fecha de publicación. En este primer paso, los personajes que asumen las características que rastreamos como específicas de lo Otro y de lo Propio son aún bastante estereotipados, y las diferencias entre ambos ámbitos son marcadas. También son bastante estancos los espacios geográficos que habitan, entre los que hay muy poca relación. Sin embargo, se sugiere hacia el final de la novela la posibilidad de que tanto Teresa como Manolo sean transformados a partir de la experiencia de haberse conocido, lo que instaura, creemos, la primera grieta en la muralla que separa lo Propio de lo Foráneo. Pensamos que en esta novela se vislumbra no todavía la mezcla, pero sí una zona gris de mutua influencia y transformación. Es aún un primer paso, por lo que las contradicciones y las diferencias entre lo local y lo migrante son todavía sólidas, como sólidos son los muros que los separan.

El segundo paso en el debilitamiento de bordes que separan lo Propio catalán de lo Otro migrante lo hallamos en La oscura historia de la prima Montse (1970). Esta novela todavía presenta personajes, como Nuria o Manuel, que se integran cabalmente en el espacio de lo autóctono y de lo migrante respectivamente. También Marsé textualiza espacios geográficos vinculados exclusivamente con ambos términos de la dicotomía. Sin embargo, esta novela presenta también la posibilidad del mestizaje, tanto a nivel narrativo como en la misma densidad de la escritura. De este modo, Marsé textualiza diversos personajes que se configuran 
como híbridos, ya sea por su origen mestizo — tal es el caso del narrador Bodegas—o por su experiencia vital—Montse, nacida en el seno de una familia catalana, quien decide trasladarse al espacio de lo migrante, como ya lo había hecho su tía Conchi. Los espacios también comienzan a imbricarse, y surgen personajes que transitan ambos ámbitos. Este segundo paso implica entonces una posibilidad de cruce, una fragmentación mayor en aquellas fronteras que separan lo Propio de lo Otro. La homogeneidad comienza a desarmarse, y también los significados asociados exclusivamente a cada uno de estos espacios. La fisonomía de Paco lo inscribe simultáneamente en lo catalán y en lo sureño; Montse se desplaza de lo catalán a lo migrante sin integrarse cabalmente en ninguno de los dos ámbitos. En la simultaneidad de significados en un mismo personaje o espacio se registran las grietas de las fronteras que salvaguardan lo homogéneo. En La oscura historia todo comienza a mezclarse, lo que permite implicar que las murallas que separan lo Propio de lo Otro se fragmentan.

El tercer paso en la construcción de una idea de identidad nacional de bordes abiertos se registra en El amante bilingüe, de 1990. Esta novela, ambientada en el contexto histórico de la normalización lingüística en Cataluña, hace estallar las murallas que separan lo Propio de lo Otro al situar el conflicto de la identidad cultural y social de Cataluña dentro de la psiquis de un mismo personaje. La novela textualiza las dos fuerzas en tensión, encarnadas en la figura dual de Marés/Faneca, pero también propone una nueva figura de síntesis, el Torero Enmascarado. En El amante bilingüe, los bordes que separan lo Propio catalán de lo Otro migrante estallan, lo que en el plano individual da lugar a la psicosis. Consideramos que la locura que atraviesa al personaje del Torero Enmascarado es la que permite vehiculizar un reclamo de integración, y una idea de nación heterogénea, abierta a la diferencia.

El difuminado de bordes entre lo autóctono y lo foráneo que leemos en las novelas estudiadas no es un fenómeno armónico y sin contradicciones. Las fronteras a veces estallan, y dejan en sus ruinas la incertidumbre que caracteriza a la pérdida de la univocidad moderna. 
Manolo y Teresa transitan su mutua transformación con vacilación y Paco muchas veces se refiere a su condición de "Claramunt bastardo" (Marsé La oscura 15) con sentimientos de angustia y descolocación. Montse es abandonada por Manuel y decide quitarse la vida: ha perdido la inocencia de saberse protegida detrás de los muros de lo Propio, en los que ahora ve las grietas y la desolación del refugio perdido. La psiquis de Marés también se ve abatida por el estallido de fronteras, y vive en sí mismo una diversidad esquizoide. La ruptura del concepto clásico de nación no es armónica, pues implica una crisis de un sistema de ideas, compatible con la posmodernidad. La condición posmoderna, sabemos, se asocia con una crisis estructural, en la que se fragmentan, entre otros conceptos, el de estado-nación. Aunque consideramos que el nuevo concepto de nación que leemos en las novelas de Marsé es superador del acuñado en la modernidad, también creemos importante hacer visible su carácter conflictivo. Esta nueva forma de hacer comunidad se vincula con un contexto de transformación radical del sujeto y de la sociedad, lo que da lugar a una crisis no exenta de contradicciones.

Por otro lado, la estrategia lingüística es también consistente con las lógicas de la mezcla y de la hibridez características de la posmodernidad. Esta estrategia se asocia con el hecho de que Marsé es un escritor catalán de expresión castellana, lo que, creemos, lo ubica en un lugar de borde. Desde este lugar puede dar cuenta de la diferencia cultural de Cataluña, separándose al mismo tiempo del castellano estándar normativizado por la Real Academia Española, localizado en Madrid, y de la idea de que la única lengua que puede representar la realidad de Cataluña es el catalán. Marsé elige como lengua vehiculizadora del texto literario un castellano híbrido, interferido a nivel léxico, morfológico y sintáctico por el catalán, y en esto también vemos un guiño a la idea del mestizaje. En la opción por esta lengua literaria, nuevamente se corroen los bordes que separan lo local de lo migrante: se configura así una idea de nación catalana mestiza, de cruce, abierta a la interpenetración de lenguas. En la elección de este castellano creemos que hay, nuevamente, una fragmentación de las fronteras que 
circunvalan al purismo lingüístico, característico de la mirada nacionalista que considera que a una nación le corresponde una (y solamente una) lengua. Nuevamente resulta productiva la figura autoral del francotirador: las balas de Marsé atacan al mismo tiempo al español estándar de la Real Academia de Madrid y a la idea del catalán como única lengua capaz de representar a Cataluña.

En la estrategia lingüística que leemos en Marsé se escuchan los ecos de lo que ya afirmó Hobsbawm, quien sostiene que la lengua es un artefacto cultural, y no la base de la conciencia nacional, como tradicionalmente afirma lo que él llama "el mito nacionalista" (Naciones 111). En tanto constructo social, la lengua no es aséptica y se encuentra atravesada por tensiones de poder. En el castellano de cruce que estructura la obra de Marsé se observan estas líneas de poder, y, como hemos revisado, se lleva a cabo la acción del llevar al centro un castellano tradicionalmente encuadrado en el espacio de lo periférico. En esto también vemos una crisis y una ruptura, que se encuadran dentro de la mirada multívoca de la posmodernidad.

Es indudable, además, el mayor alcance del castellano sobre el catalán en términos de difusión y cantidad de hablantes. En la mayor posibilidad de amplificación del mensaje leemos también una mayor apertura. Este mensaje se sitúa en un espacio geográfico particular-y delimita un locus característico—y se dirige a una audiencia más amplia.

En conclusión, consideramos que Últimas tardes con Teresa, La oscura historia de la prima Montse y El amante bilingüe configuran tres etapas sucesivas en la configuración de un discurso nacional para Cataluña consistente con nuestro tiempo histórico. Como afirma Bhabha, la nación se construye en y a través de sus discursos, lo que habilita una lectura en esta dirección. Este discurso nacional catalán, rastreable en tres novelas que se integran en veinticuatro años de devenir histórico, es coherente con un contexto específico, asociado a la movilidad de personas y capitales. Es factible plantear que la idea de nación legible en las novelas revisadas se distancia del nacionalismo clásico (monolítico y excluyente, de murallas 
claras que separan lo local de lo extranjero) y propone una idea de nación que se desarrolla en tres pasos representados por cada una de las novelas.

En cuanto a los aportes originales de esta tesis a la bibliografía existente sobre la obra de Marsé cabe destacar, en primer término, el análisis del cruce de ciertas obras de su novelística con los discursos teóricos sobre la conceptualización de la nación, atravesado por los aportes filosóficos de la posmodernidad. Esta tesis se focaliza en la construcción de una identidad nacional alternativa, que establece nuevos lazos identitarios de pertenencia, más consistentes con nuestro tiempo. Asimismo, este estudio se detiene específicamente en el análisis de La oscura historia de la prima Montse, novela que, a pesar del extenso trabajo crítico existente sobre la obra del escritor catalán, no ha sido muy frecuentemente objeto de análisis. Esta carencia de bibliografía crítica se comprueba en la densidad del tercer capítulo de esta tesis, que se erige como una contribución original a ese corpus. Por otra parte, no existe un análisis anterior tan pormenorizado de los fenómenos específicos de interferencia del catalán en el castellano que configura la lengua literaria de Marsé como el presentado en el capítulo quinto de este trabajo. Consideramos que esa investigación abre el campo para nuevos estudios sobre fenómenos de interferencia lingüística en otras novelas de Marsé, o incluso de otros escritores catalanes de expresión castellana.

Es pertinente también aquí trazar nuevas líneas de investigación para futuros trabajos. Creemos que una de ellas se insinúa en el capítulo cuarto, ya que consideramos que podría observarse nuevamente el registro de una nueva figura migrante, aún estereotipada e integrada en las clases populares. Cabría rastrear, entonces, qué tipo de representaciones de lo migrante y de lo catalán pueden hallarse en las novelas más recientes de Marsé. Otra posible línea de trabajo se abre a las representaciones del estado español en la obra de Marsé, y de qué manera se articulan esas representaciones con aquellas que involucran lo catalán. También nuestro trabajo sobre lo que hemos denominado estrategia lingüística abre la posibilidad de revisar la 
lengua literaria de otros escritores catalanes de expresión castellana, y registrar qué tipo de fenómenos de interferencia pueden revelarse. Finalmente, podría también seleccionarse otro corpus de novelas de escritores catalanes contemporáneos, y estudiar qué representaciones de nación para el caso catalán se presentan en sus obras.

Como se observa, el campo de estudio de las representaciones de nación para el caso catalán en la literatura es extenso y dinámico. Los procesos históricos que ha atravesado Cataluña en los últimos años se estructuran en una idea de nación bastante monolítica, en concordancia con la ideología nacionalista clásica. Visualizar estas conceptualizaciones, y rastrear otras posibilidades podría significar un aporte para intentar plantear una alternativa superadora de modelos excluyentes, más abierta a la diversidad. 


\section{Trabajos citados}

Aguilar Porras, Elber. “El catalán: ¿iberorromance o galorromance?” Repertorio americano, núm. 24, 2014, pp. 95-114.

Alted Vigil, Alicia. "Los niños de la guerra civil.” Anales de historia contemporánea, vol. 19, 2003, pp. 43-58.

Amell, Samuel. “Conversación con Juan Marsé.” España contemporánea: Revista de literatura y cultura, vol. 1, núm. 2, 1988, pp. 81-101.

Anderson, Benedict. Comunidades imaginadas. Reflexiones sobre el origen y la difusión del nacionalismo. Fondo de cultura económica, 1993.

Aracil, Lluis. "Conflit linguistique et normalisation linguistique dans l'Europe nouvelle." Cahiers de L’Irsce, núm. 1, octubre 1976, pp. 1-20.

Aramburu, Mikel. “¿Vindicando al charnego? El discurso autobiográfico de Javier Pérez Andújar y Jorge Javier Vázquez.” Revista de dialectología y tradiciones populares, vol. LXXXI, núm. 1, 2016, pp. 129-49.

Arana, Marta, y Carolina Castillo. "Identidades, parodia y carnavalización en El amante bilingüe, de Juan Marsé.” Espéculo: Revista de estudios literarios, núm. 24, 2003, pp. $46-52$.

Azúa, Félix de. "Últimos oros." El País, 11 diciembre 2014, Elpais.com, https://elpais.com/cultura/2014/12/04/babelia/1417714758_321655.html

Baczko, Bronislaw. Los imaginarios sociales. Memorias y esperanzas colectivas. Nueva Visión, 1999.

Badia i Margarit, Antoni. "Lenguas en contacto", separata de Comunicación y lenguaje, coordinado por Rafael Lepesa, Karpos, 1977.

---. Llengua i cultura als Països Catalans. Edicions 62, 1972. 
Bajtin, Mijail. La cultura popular en la Edad Media y en el Renacimiento. Alianza, 2003.

Balcells, Albert. Breve historia del nacionalismo catalán. Alianza, 2004.

Ballesteros, Pedro. Imprescindibles. Érase una vez Juan Marsé. Youtube, subido por Algún día en alguna parte, 10 de marzo de 2015, https://www.youtube.com/watch?v=hFiI9btvA8A\&t=666s

Barrera González, Andrés. "Lengua, identidad y nacionalismo en Cataluña durante la transición.” Revista de antropología social, 1997, pp. 109-37.

---. La dialéctica de la identidad en Cataluña: un estudio de antropología social. Centro de investigaciones sociológicas, 1985.

Bauman, Zygmunt. Modernidad líquida. Fondo de cultura económica, 2004.

Belmonte Serrano, José. "Juan Marsé: Nociones sobre la escritura invisible (entrevista)." Nuevas tardes con Marsé. Estudios sobre la obra literaria de Juan Marsé, editado por José Belmonte Serrano y Juan Manuel López de Abiada, Nausícaa, 2002, pp. 25-34.

Benjamin, Walter. "Sobre algunos temas en Baudelaire." El París de Baudelaire, Eterna cadencia, 2012, pp. 47-75.

Betrisey Nadali, Débora. "Inmigración y discriminación en la frontera argentino-paraguaya." Migraciones internacionales, vol. 4, núm. 1, 2007, pp. 141-64.

Bhabha, Homi. "Diseminación. El tiempo, el relato y los márgenes de la nación moderna." El lugar de la cultura, Manantial, 2002, pp. 175-209.

Bhabha, Homi, "Narrando la nación”. Fernández Bravo, pp. 211-19.

Birulés, Fina. El género de la memoria. Pamiela, 1995.

Blas Arroyo, José. "Problemas teóricos en el estudio de la interferencia lingüística." Revista española de lingüística, vol. 21, núm. 2, 1991, pp. 265-89.

Bloomfield, Leonard. Language. Holt, Rinehart and Winston, 1933. 
Boadas Llavat, Agustí. “Seny y rauxa en Ramón Llull y Francesc Eiximenis.” Revista española de filosofía medieval, vol. 22, 2015, pp. 43-52.

Botrel, Jean-François. "La novela por entregas: unidad de creación y consumo.” Creación y público en la literatura española, editada por Jean-Francois Botrel et al., Castalia, 1974, pp. 111-55.

Bourdieu, Pierre. "La ilusión biográfica." Razones prácticas. Sobre la teoría de la acción, Anagrama, 1997, pp. 74-83.

Buckley, Ramón, et al. “Características de la novela de los cincuenta." Historia y crítica de la literatura española, editada por Francisco Rico, Tomo VIII, Crítica, 1980, pp. 410-27.

Calmes, Victoria. “Alienación cultural y dislocación de la subjetividad en 'El amante bilingüe' de Juan Marsé.” RILCE: Revista de filología hispánica, vol. 25, núm. 2, 2009, pp. 20919.

Canal, Jordi. "El Estado autonómico: reflexiones históricas sobre Cataluña y el nacionalismo catalán.” Cuadernos de pensamiento político, vol. 32, 2011, pp. 59-71.

Canales Serrano, Francisco. "El robo de la memoria. Sobre el lugar del franquismo en la historiografía católico-catalanista.” Ayer, vol. 59, núm. 3, 2005, pp. 259-80.

Carandell, José María. “Juan Marsé o ¿te acuerdas de Teresa?” Rodríguez Fischer, pp. 235-37.

Carreras, Francesc de. "Opinión pública y secesionismo: el caso catalán.” Cuadernos de pensamiento político, vol. 44, 2014, pp. 23-38.

Casassas i Ymbert, Jordi. "Nación y nacionalismo: notas para el estudio comparado del caso catalán en relación al resto de nacionalismos periféricos de España." Cercles. Revista d'història cultural, vol. 12, 2009, pp. 8-25.

Castillo, David. “Los anarquistas en la obra de Juan Marsé.” Rodríguez Fischer, pp. 45-53.

Certeau, Michel de. La invención de lo cotidiano. I. Artes de hacer. U Iberoamericana, 2000. 
Clark, Rosemary. Catholic Iconography in the Novels of Juan Marsé. Boydell and Brewer, 2003.

Cleary Nichols, Geraldine. "Dialectical Realism and Beyond: Últimas tardes con Teresa." Journal of Spanish Studies: Twentieth Century, vol. 3, núm. 3, 1975, pp. 163-74.

Clua i Fainé, Montserrat. "Algunos factores explicativos del reciente auge del nacionalismo catalán." Quaderni di antropología e scienze umane, núm. 2-3, septiembre 2015, pp. $63-73$.

---. "Catalanes, inmigrantes y charnegos: "raza", "cultura" y "mezcla" en el discurso nacionalista catalán.” Revista de antropología social, vol. 20, 2001, pp. 55-75.

---. "Identidad y política en Cataluña: el auge del independentismo en el nacionalismo catalán actual." Quaderns-e, Institut català d'antropologia, vol. 19, núm. 2, 2014, pp. 79-99.

Clyne, Michael. Dynamics of Language Contact. English and Immigrant Languages, Cambridge UP, 2003.

Conboy, Katie, et al. Writing on the Body. Female Embodiment and Feminist Theory. Columbia UP, 1997.

Connor, Laura. "Bilingualism, Desdoblamiento and Dissociative Identity in Juan Marsé's El amante bilingüe." The Proceedings of the UCLA Department of Spanish and Portuguese Graduate Conference, vol. 1, 2012, pp. 3-14.

Connor, Walker. "A Nation is a Nation, is a State, is an Ethnic Group, is a..." Ethnonationalism. The Quest for Understanding. Princeton UP, 1994, pp. 89-117.

Conte, Rafael. “Un apasionado del cine.” Rodríguez Fischer, pp. 467-71.

Cornellà-Detrell, Jordi. Literature as a Response to Cultural and Political Repression in Franco's Catalonia. Tamesis, 2011.

Cuenca, Josep Maria. Mientras llega la felicidad. Una biografía de Juan Marsé. Anagrama, 2015. 
Deiser, Andrew. “Competing Social Values in Juan Marsé’s El amante bilingüe.” Hispanófila, núm. 158, 2010, pp. 67-81.

Derrida, Jacques. "La lengua no pertenece.” Entrevista con Evelyne Grossman, Mensuario Europe, vol. 79, núm. 861/862, enero-febrero 2001. Traducción de Ricardo Ibarlucía publicada en Diario de poesía núm. 58, primavera 2001. Edición digital: https://redaprenderycambiar.com.ar/derrida/textos/celan.htm

---. El monolingüismo del otro o la prótesis de origen. Traducido por Horacio Pons, Manantial, 1997.

Diccionario de dudas y dificultades de la lengua española. Espasa-Calpe, 1990.

Domanska, Ewa, et al. "Hayden White: The Image of Self-Presentation." Diacritics, vol. 24, núm. 1, Spring 1994, pp. 91-100.

Domingo, José. “Del realismo crítico a la nueva novela.” Rodríguez Fischer, pp. 238-42.

Domínguez Quintana, Rubén. "Marés, Faneca y el torero enmascarado o cómo asaltar el mito nacional y monolingüe en El amante bilingüe, de Juan Marsé.” Bulletin of Hispanic Studies, vol. 89, núm. 3, 2012, pp. 292-301.

Doria, Sergi “Juan Marsé: la literatura española goza de buena salud." Revista cultural Turia, vol. 123 , pp. $323-31$.

Doria, Sergi, y Andreu Gilaberte. "Entrevista a Juan Marsé. Número 2145 de la Revista del Forment." YouTube, subido por F. La Revista del Foment, 21 septiembre 2015, https://www.youtube.com/watch?v=1FJi8dhh4SI\&t=510s

Dubois, Jean, et al. Dictionnaire de Linguistique. Larousse, 1973.

Eco, Umberto. "Los marcos de la 'libertad' cómica.” ¡Carnaval!, editado por U. Eco et al., Fondo de cultura económica, 1989, pp. 9-20.

---. Lector in fabula. La cooperación interpretativa en el texto narrativo. Lumen, 1993. 
Edwards, John. "Introduction". Linguistic Minorities, Policies and Pluralism, editado por J. Edwards, Academic Press, 1984, pp. 1-16.

Elián, Juan. El gran libro de los apellidos y la heráldica. Robinbook, 2001.

Escobedo, María. "Juan Marsé: 'De una novela sólo es verdad lo que se cree el lector'." Cuadernos hispanoamericanos, 2011, vol. 732, 2011, pp. 125-31.

Fabra, Pompeu. Diccionari general de la llengua catalana. Edhasa, 1977.

Faix, Dora. "La guerra civil y la posguerra a través del espacio narrativo. Análisis de Si te dicen que caí de Juan Marsé.” Études romanes de Brno, núm. 30, vol. 2, 2009, pp. 37-46.

Fanon, Frantz. Piel negra, máscaras blancas. Akal, 2009.

Ferguson, Charles. "Diglossia." Word, 15, 1959, 325-40, incluido en Antología de estudios etnolingüísticos y sociolingüísticos, compilado por Paul Garvin y Yolanda Lastra, y traducido por Joaquín Herrero, UNAM, 1974, pp. 247-65.

Fernández Bravo, Álvaro. La invención de la nación. Lecturas de la identidad de Herder a Homi Bhabha. Manantial, 2000.

Ferré, Xavier. “Sobre historiografía del nacionalismo catalán.” Ayer, vol. 40, 2000, pp. 21525.

Fioretti Katz, Lorena. "Extraterritorialidad y extimidad: el monolingüismo del otro como política de la lengua." Humanidades. Revista de la Universidad de Montevideo, núm 12, 2012, pp. 75-97.

Fischer, Nancy. "Purity and Pollution: Sex as a Moral Discourse." Handbook of the New Sexuality Studies, editado por S. Seidman, N. Fischer y C. Meeks, Routledge, 2006, pp. $56-63$.

Fishman, Joshua. "Bilingualism with and without Diglossia, Diglossia with and without Bilingualism.” Journal of Social Issues, vol. 23, núm. 2, 1967, pp. 29-38.

---. Sociolinguistics. Newbury House, 1971. 
Folch, Ernest. "El embrujo de Shangai.” Rodríguez Fischer, pp. 425-26.

Fombellida Velasco, Luis, y José Sánchez Moro. "Personalidad múltiple: un caso raro en la práctica forense.” Cuadernos de medicina forense, núm. 31, enero 2003, pp. 5-11.

Forrest, Gene Steven. 'From Masquerade to Reminisence: Modes of Parody in Juan Marsé’s El amante bilingüe.” Hispanófila, núm. 113, enero 1995, pp. 45-53.

García Montero, Luis “Si te dicen que Marsé.” Rodríguez Fischer, pp. 58-62.

García Ponce, David. “La imagen literaria del extrarradio en la novela española contemporánea (1950-1979).” Dicenda, vol. 33, 2015, pp. 71-87.

Gellner, Ernest. Nations and Nationalism. Basil Blackwell, 1993.

Gilabert, Joan. “Catalunya y la obra de Juan Marsé.” Ojáncano, núm. 1, 1988, pp. 61-71.

Gramsci, Antonio. Antología. Siglo XXI, 1981.

Griera, Antoni. La frontera catalano-aragonesa. Estudi geogràfico-lingüístic. Institut d'estudis catalans, 1914.

Guisasola, Dana. “'El Pijoaparte sería hoy un muchacho magrebí': entrevista a Juan Marsé.” Journal of Iberian and Latin American Research, vol. 24, núm. 3, 2018, pp. 278-88.

Gumperz, John. Language in Social Groups. Stanford UP, 1971.

Hamel, Rainer Enrique, y María Teresa Sierra. "Diglosia y conflicto intercultural: La lucha por un concepto o la danza de los significantes." Boletín de antropología americana, vol. 8, 1983, pp. 89-110.

Haugen, Einar. "Problems of Bilingual Descriptions." Monograph Series on Languages and Linguistics, núm. 7, 1954, pp. 9-19.

---. Bilingualism in the Americas: A Bibliography and a Research Guide. U of Alabama P, 1956. 
Hernández García, Carmen. "Una propuesta de clasificación de la interferencia lingüística a partir de dos lenguas en contacto: el catalán y el español.” Hesperia: anuario de filología hispánica, núm. 1, 1998, pp. 61-80.

Hevia, Elena. "Juan Marsé, una vida." El Periódico, 2 marzo 2015. Elperiodico.com, http://www.elperiodico.com/es/ocio-y-cultura/20150301/juan-marse-una-vida3979729

Hobsbawm, Eric. “Etnicidad y nacionalismo en Europa hoy.” Fernández Bravo, pp. 173-84.

---. Naciones y nacionalismo desde 1780. Grijalbo Mondadori, 1998.

Hornby, Peter. "Bilingualism: An Introduction and Overview." Bilingualism. Psychological, Social and Educational Implications, edited by Peter A. Hornby. Academic Press, 1977, pp. 1-14.

Hout-Huijben, Lidwina M. van den. El rojo crítico. Expansión de la literatura catalana bajo censura (1962-1977). U of Groningen, 2015, $\mathrm{PhD}$ dissertation. https://www.rug.nl/research/portal/files/17027535/Binder1.pdf

Hudson, Alan. "Diglossia, Bilingualism, and History: Postscript to a Theoretical Discussion." International Journal of the Sociology of Language, núm. 157, 2002, pp. 151-65.

Izquierdo, Luis. "Últimas tardes con Teresa, una novela de imágenes de hilos entrelazados." Rodríguez Fischer, pp. 167-83.

Jameson, Fredric. Ensayos sobre el posmodernismo. Imago mundi, 1991.

Jiménez, Pedro. "Historia y civilización. Apuntes sobre la censura durante el franquismo." Boletín AEPE. vol. 17, 1977, pp. 3-8.

Kedourie, Elie. Nationalism. Frederick A, 1960.

Kim, Kwang-Hee. "En torno al bilingüismo en Cataluña: El amante bilingüe (1990), de Juan Marsé.” Revista hispánica moderna, año 56, núm. 2, diciembre 2003, pp. 357-72. 
King, Stewart. "Catalan Literature(s) in Postcolonial Context.” Romance Studies, vol. 24, núm. 3, 2006, pp. 253-64.

---. "Desempeñar papeles y la desmitificación cultural en El amante bilingüe, de Juan Marsé.” Journal of Iberian and Latin American Research, vol. 5, núm. 1, 1999, pp. 73-85.

---. Escribir la catalanidad. Lengua e identidades culturales en la narrativa contemporánea de Cataluña. Tamesis, 2005.

Kremnitz, Georg. 'Du 'bilinguisme' au 'conflit linguistique'. Cheminement de termes et de concepts.” Languages, núm 16, 1981, pp. 63-74.

Lamadrid, Carlos. “Juan Marsé ha ganado el Premio Cervantes 2008.” Diario Exterior, 28 noviembre 2008. Eldiarioexterior.com, https://www.eldiarioexterior.com/juan-marseha-ganado-el-23859.htm

Lee Six, Abigail. "La oscura historia del primo Paco/Francesc." Bulletin of Hispanic Studies, núm. 76, 1999, pp. 359-66.

---. “Blind Woman's Buff: Optical Illusions of Feminist Progress in Juan Marsé, El amante bilingüe." Journal of Iberian and Latin American Studies, vol. 6, núm. 1, 2010, pp. 2941.

Lipovetsky, Gilles. La era del vacío. Anagrama, 2006.

López Rodríguez, Lucía et al. “Aplicación extendida del Modelo del Contenido de los Estereotipos (MCE) hacia tres grupos de inmigrantes en España." Estudios de psicología, vol. 34, núm. 2, pp. 197-208.

Lugones, María. “Colonialidad y género.” Tábula rasa, núm 9, 2008, pp. 73-101.

Lyons, John. New Directions in Linguistics. Penguin, 1970.

Lyotard, Jean-Francois. La condición posmoderna: informe sobre el saber. Cátedra, 1991.

Mackey, William F. Bilinguisme et contact des langues, Klincksieck, 1976.

Mainer, José-Carlos. “El vengador de la memoria.” Rodríguez Fischer, pp. 246-49. 
---. “Juan Marsé o la memoria en carne viva.” Rodríguez Fischer, pp. 66-76.

---. “Juan Marsé.” Boletín informativo Fundación Juan March, vol. 320, pp. 3-12.

Mangini González, Shirley. "Últimas tardes con Teresa: culminación y destrucción del realismo social en la novelística española." Anales de la narrativa española contemporánea, vol. 5, 1980, pp. 13-26.

Mar-Molinero, Clare. The Politics of Language in the Spanish-Speaking World. Routledge, 2000.

Marcer, Elisenda. "Luis Cernuda como puente entre la poesía inglesa y la 'Escuela de Barcelona'." Journal of Iberian and Latin American Studies, vol. 11, nos. 2-3, 2005, pp. 189-96.

Marsé, Juan. "Primera imagen, primer latido.” El Sol, 5 de octubre de 1990, p. 2.

---. La oscura historia de la prima Montse. Seix Barral, 1990.

---. Últimas tardes con Teresa. Seix Barral, 1993.

---. El amante bilingüe. Planeta, 1993.

Martí Gómez, José. “Juan Marsé.” Mercurio, vol. 10, 2009, pp. 11-13.

Martín Garzo, Gustavo. “Prólogo.” Rodríguez Fischer, pp. 250-54.

Martín Miñana, Pau. "El sistema demostrativo español y catalán a lo largo de las gramáticas." Orillas, núm.7, 2018, pp. 329-47.

Marzá, Fernando, y Neus Moyano. "Walden 7. Ciutat en 1'espai, experiencia 3 de Ricardo Bofill, Taller de Arquitectura." Quaderns d'arquitectura i urbanisme, núm. 244, diciembre 2004, pp. 20-29.

McLaughlin, Barry. Second Language Acquisition in Childhood: Volume 1. Preschool children. Lawrence Erlbaum, 1984. 
Mendizábal, María Florencia. “Construyendo la 'otredad': imágenes y proyecciones teóricas cristianas sobre los musulmanes en la España Medieval (ss. XIII-XV).” Revista chilena de estudios medievales, núm. 5, 2014, pp. 53-72.

Millet i Loras, Lluís. "El llegat històric de l’Orfeó Català (1891-1936).” Recerca musicològica, vol. 14-15, 2004-2005, pp. 139-53.

Miró i Rufà, Josep Maria. "Walden 7." Cuadernos de arquitectura y urbanismo, núm. 111, 1975, pp. 13-21.

Moreno Fernández, Francisco. Principios de sociolingüística y sociología del lenguaje. Ariel, 1998.

Moreno Seco, Mónica. “Creencias religiosas y política en la dictadura franquista.” Pasado y memoria. Revista de historia contemporánea, núm. 1, 2002, pp. 111-30.

Mulvey, Laura. "Placer visual y cine narrativo." Arte después de la modernidad. Nuevos planteamientos en torno a la representación, editado por Brian Wallis y traducido por Carolina del Olmo y César Rendueles, Akal, 2001, pp. 364-77.

Muysken, Pieter, et al. Bilingual Speech: A Typology of Code-Mixing. Cambridge UP, 2000.

Muysken, Pieter y Roeland van Hout. "Insertion, Alternation, Congruent Lexicalization. Corpus-based Approaches to Bilingual Speech.” Summer School Code Switching and Language Contact, núm. 14-17, September 1994, pp. 302-07.

Ninyoles, Rafael. Conflicte lingüístique valencià. Tres i quatre, 1969.

---. Estructura social y política lingüística. Fernando Torres, 1975.

Nussbaum, Felicity. The Autobiographical Subject. Gender and Ideology in EighteenthCentury England. The Johns Hopkins UP, 1989.

Oleza, Joan. “Un realismo posmoderno.” Ínsula: revista de letras y ciencias humanas, núm. 589, 1996, pp. 39-42.

Ordóñez, Marcos. “Marsé y el cine.” Rodríguez Fischer, pp. 98-113. 
Overbeke, Maurice van. Mécanismes de l'interférence linguistique. Fragua, 1976.

Pascal-Casas, Danielle. "La función estructural del teatro en la novelística de Juan Marsé." Anales de la literatura española contemporánea, vol. 13, núm. 1/2, 1988, pp. 119-33.

Patiño Lakatos, Gabriela. "Economía psíquica de la caricatura política. Retórica del sujeto y lazo social.” Desde el jardín de Freud: revista de psicoanálisis, núm. 17, 2017, pp. 213 34.

Payrató, Lluis. La interfèrencia lingüística (Comentaris $i$ exemples català-castellà). Curial edicions catalanes, Publicaciones de l'Abadia de Montserrat, 1985.

Pérez Manrique, Ana. "Entrevista a Juan Marsé: en torno a El amante bilingüe." Confluencia, vol. 25, núm. 1, 2009, pp. 124-30.

Prat de la Riba, Enric. La nacionalitat catalana. Escola d'administració pública de Catalunya, 2007

http://eapc.gencat.cat/web/.content/home/publicacions/varia/24._la_nacionalitat_catal ana/nacionalitat_catalana.pdf

Puig i Moreno, Gentil, "Reflexions sobre llegua i identitat." Treballs de sociolingüística catalana, núm. 7 , pp. 31-49.

Rank, Otto. The Double: A Psychoanalytical Study. Traducido y editado por Harry Tucker Jr. Chapel Hill, U of North Carolina P, 1971.

Recio Meroño, Paloma. "Entrevista a Juan Marsé.”, Confluencia, vol. 28, núm. 1, 2012, pp.120-31.

Regàs, Rosa. "El impagable vuelo del talento.” Rodríguez Fischer, pp. 120-24.

Renan, Ernest. “¿Qué es una nación?” Fernández Bravo, pp. 53-66.

Resina, Joan Ramón. “The Double Coding of Desire: Language Conflict, Nation Building, and Identity Crashing in Juan Marsé's El amante bilingüe.” The Modern Language Review, vol. 96, núm. 1, Jan 2001, pp. 92-102. 
---. Barcelona's Vocation of Modernity. Rise and Decline of an Urban Image. Stanford UP, 2002.

Rico, Eduardo. “La prima Montse y su oscura historia.” Triunfo, núm. 424, 1970, p. 36.

Riera, Carmen. "El río común de Juan Marsé y Jaime Gil de Biedma.” Rodríguez Fischer, pp. 189-212.

Riquer, Borja de. Alfonso XIII y Cambó. La monarquía y el catalanismo político. RBA, 2013.

Rodríguez Fischer, Ana. Ronda Marsé. Candaya, 2008.

Romaine, Suzanne. Pidgin and Creole Languages. Longman, 1988.

Rovira i Virgili, Antoni. El nacionalismo catalán. Su aspecto político. Los hechos, las ideas y los hombres. Minerva, 1916.

Safran, William. "Nationalism." Handbook of Language and Ethnic Identity, editado por Joshua A. Fishman, Oxford UP, 1999, pp. 77-93.

Samaniego, Balbina. “Entrevista con Juan Marsé.” ALEC, vol. 18, 1993, pp. 375-88.

Sanz Villanueva, Santos. "Entre la desolación y la ternura.” Mercurio, vol. 110, 2009, pp. 8-9.

Sapir, Edward. Selected Writings of Edward Sapir in Language, Culture and Personality, edited by David Mandelbaum, Cambridge UP, 1949.

Shaw, Donald. The Generation of 1898 in Spain. Ernest Benn, 1975.

Sherzer, William. "Juan Marsé's El amante bilingüe: Looking Backward." Letras peninsulares, vol. 7, 1994, pp. 405-16.

---. Juan Marsé, entre la ironía y la dialéctica. Fundamentos, 1982.

Siguán, Miguel. "Problemas del bilingüismo." Cursos universitarios, núm. 112, febrero 1982, pp. 34-39.

Sinner, Carsten. El castellano de Cataluña. Estudio empírico de aspectos léxicos, morfosintácticos, pragmáticos y metalingüísticos. Max Niemayer Verlag Tübingen, 2004. 
Skeggs, Beverley. Class, Self, Culture. Routledge, 2004.

Smith, Anthony. “¿Gastronomía o geología? El rol del nacionalismo en la reconstrucción de las naciones.” Fernández Bravo, pp. 185-206.

---. “When is a Nation?” Geopolitics, vol. 7, núm. 2, 2002, pp. 5-32.

---. The Ethnic Origins of Nations. Oxford, Basil Blackwell, 1986.

Sobejano, Gonzalo. Novela española de nuestro tiempo. Prensa española, 1975.

Sotelo Vázquez, Adolfo. "Historia y discurso en El amante bilingüe de Juan Marsé." Ronda Marsé, pp. 380-400.

Spelman, Elizabeth. "Woman as Body: Ancient and Contemporary Views." Feminist Studies, vol. 8, núm. 1, 1982, pp. 109-31.

Suñén, Luis. “Juan Marsé, un maestro de la memoria.” Rodríguez Fischer, pp. 129-34.

Theros, Xavier. "Desde el viaducto." El País, 9 de abril 2016, https://elpais.com/ccaa/2016/04/08/catalunya/1460136354_192647.html

Thompson, Currie. "Juan Marsé's Teniente Bravo and the Playing Out of History." Anales de la literatura española contemporánea, núm. 19, 1994, pp. 151-63.

Todorov, Tzvetan. Nosotros y los otros. Siglo XXI, 2007.

Triandafyllidou, Anna. "National Identity and the 'Other'." Ethnic and Racial Studies, vol. 21, núm. 4, 1998, pp. 593-612.

Turpin, Enrique. "Introducción.” Cuentos completos, escrito por Juan Marsé, Espasa Calpe, 2002, pp. 9-151.

Valkhoff, Marius. Les Mots français d'origine néerlandaise. Valkhoff, 1931.

Vallverdú, Francesc. El conflicto lingüístico en Cataluña: historia y presente. Ediciones Península, 1981.

---. El fet lingüístic com a fet social. Edicions 62, 1980. 
Vann, Robert. "Constructing Catalanism: Motion Verbs, Demonstratives and Locatives in the Spanish of Barcelona.” Catalan Review, vol. 9, núm. 2, 1995, pp. 253-73.

Vargas Llosa, Mario. “Una explosión sarcástica en la novela española moderna.” Rodríguez Fischer, pp. 217-21.

Vázquez Montalbán, Manuel. Ciclo El intelectual y su memoria: Juan Marsé. Youtube. Subido por Facultad de filosofía y letras UGR, 19 junio de 2015, https://www.youtube.com/watch?v=obufo-0K2-s

---. “El amante trilingüe.” Rodríguez Fischer, pp. 405-10.

---. “La memoria de Juan Marsé.” Rodríguez Fischer, pp. 137-47.

---. “Los años épicos de los señoritos de izquierda.” Rodríguez Fischer, pp. 222-25.

Veny, Joan. "Sobre la interferencia catalán-castellano." Romanische Sprachwissenchaft. Zeugnisse für Vielfalt und Profil eines Faches. Festschrift für Christian Schmitt zum 60. Geburtstag., editado por Alberto Gil et al., 2004, pp. 339-52.

Vidal Folch, Ignacio, y Pedro Secorun Portola. "Marsé, un escritor decimonónico.” Triunfo, vol. 824,1978 , pp. $68-69$.

Vila-Matas, Enrique. “Un pirata de Caribe.” Rodríguez Fischer, pp. 148-52.

Vilanova, Antoni. “Juan Marsé o la desmitificación del progresismo estudiantil y del romanticismo revolucionario: Últimas tardes con Teresa." Rodríguez Fischer, pp. 22632.

Villamandos, Alberto. "Las trampas de la nostalgia: la gauche divine de Barcelona en su producción literaria.” Revista de estudios hispánicos, vol. 42, núm. 3, 2008, pp. 45982.

Wei, Li. "Bilingualism." Encyclopedia of Language and Linguistics, Vol. 2, Second Edition, editado por Keith Brown, Elsevier, 2006, pp. 1-12.

Weinreich, Uriel. Languages in Contact. Findings and Problems. The Hague, 1936. 
White, Hayden. "Fictions of Factual Representation." Tropics of Discourse: Essays in Cultural Criticism, The Johns Hopkins UP, 1978, pp. 121-34.

Young, Iris. "Throwing Like a Girl: A Phenomenology of Feminine Body Comportment Motility and Spatiality”. Human Studies, vol. 3, núm. 1, 1980, pp. 137-56.

Zovko, Maja. "Algunas peculiaridades de la narrativa actual sobre la inmigración extranjera en España.” Grup de recerca sobre migraciones (GRM), 2014, pp. 1-13. 